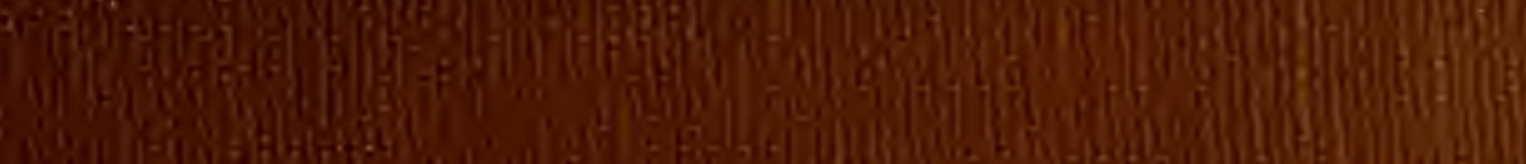

thengumary

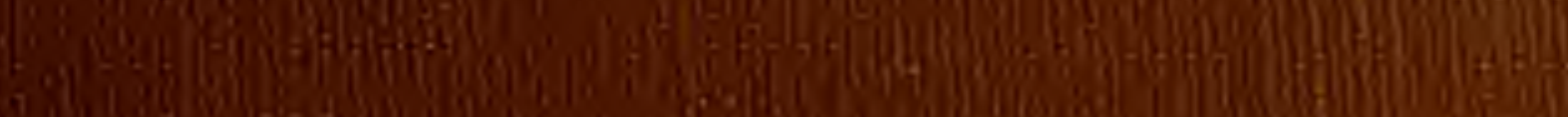
(1) 


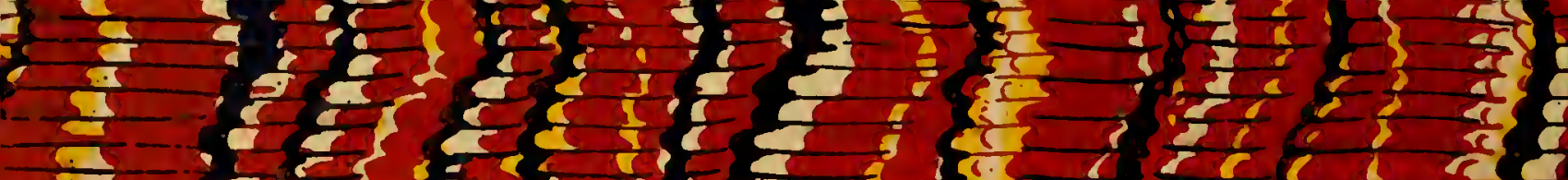

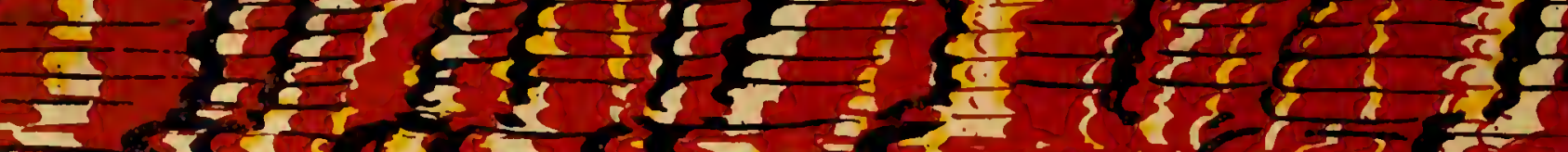

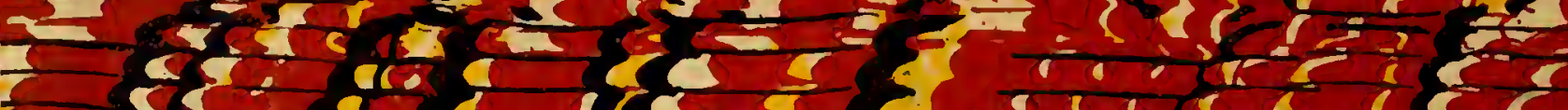

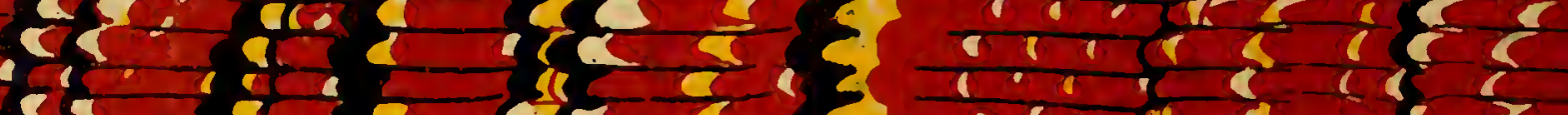

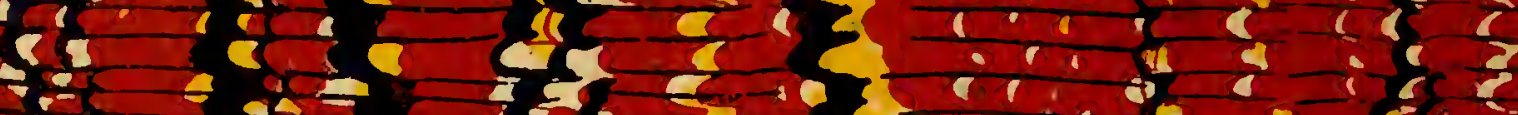

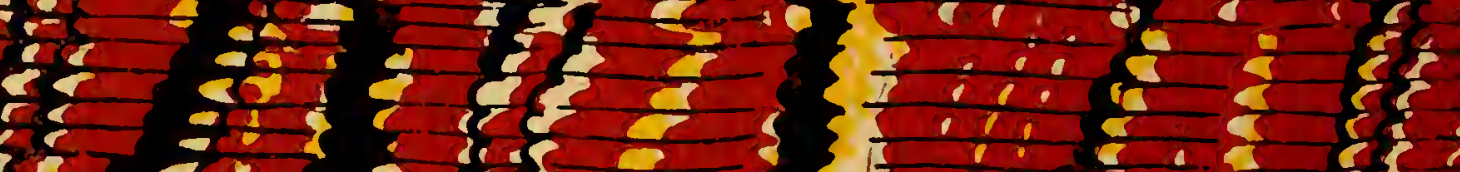

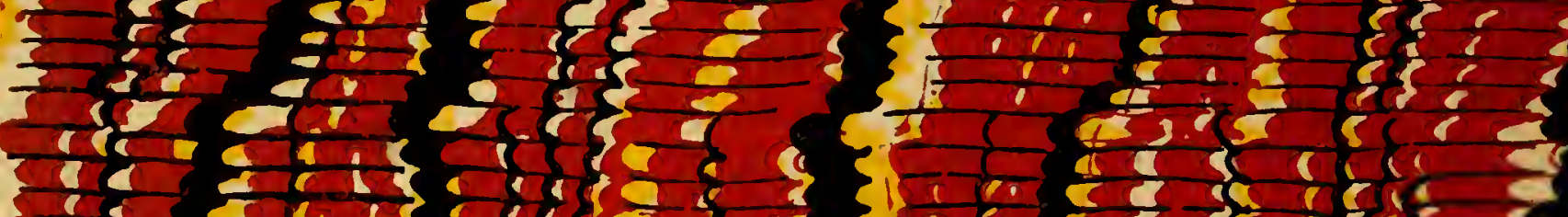

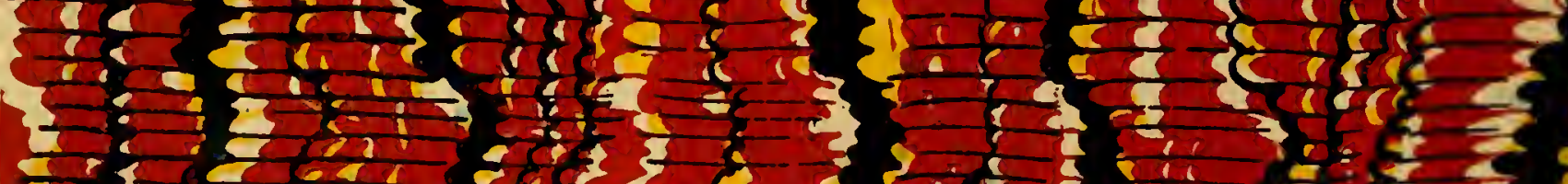

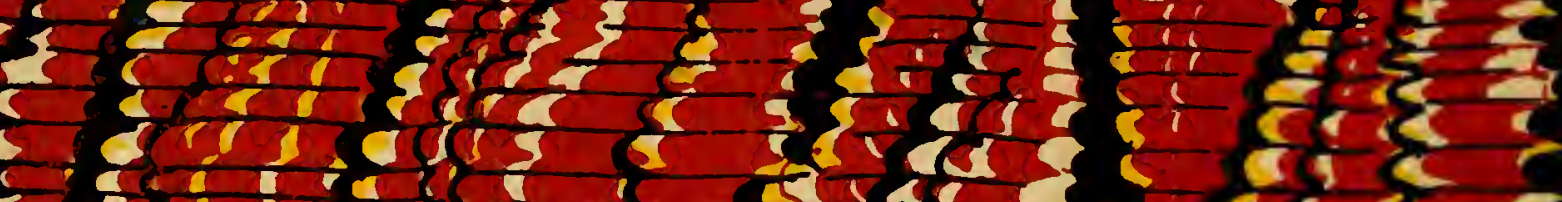

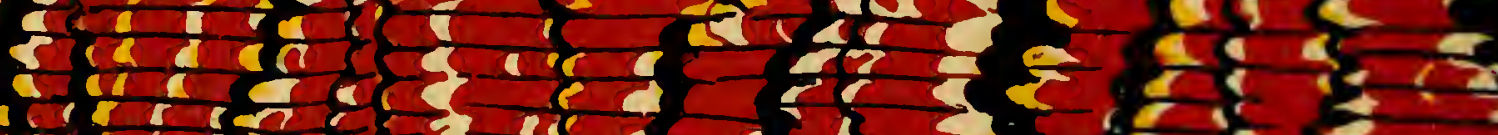

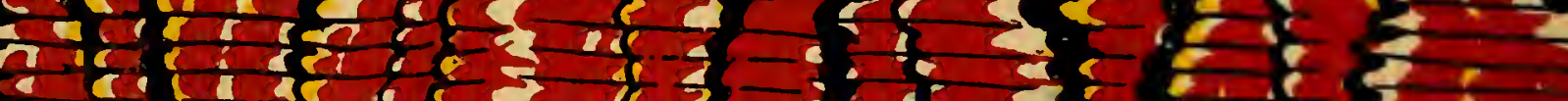

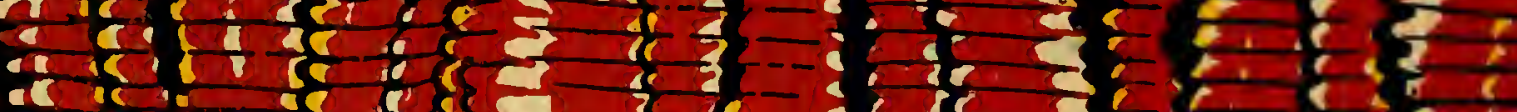

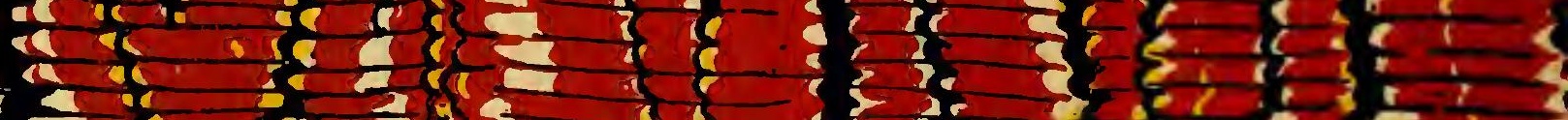

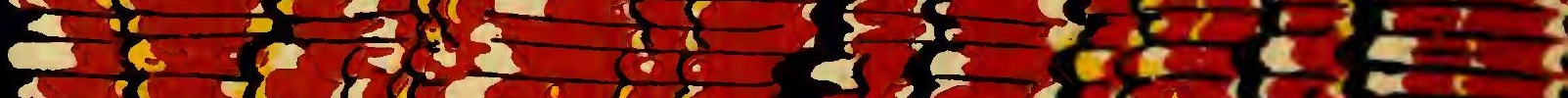

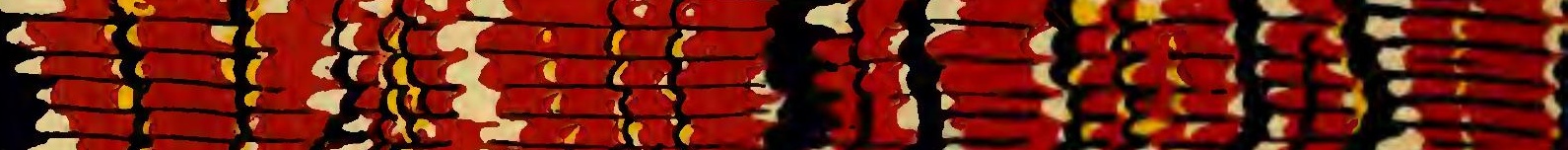

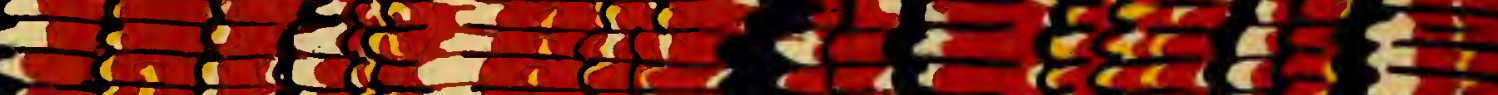

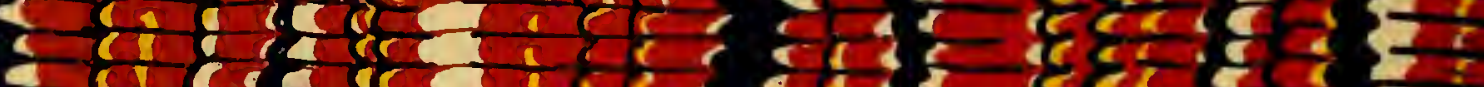

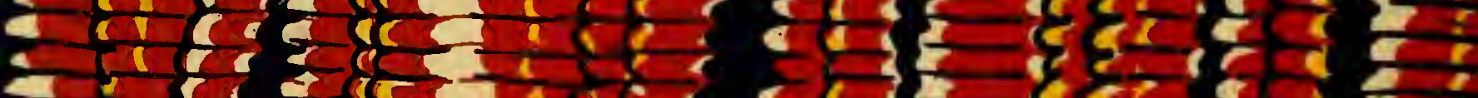

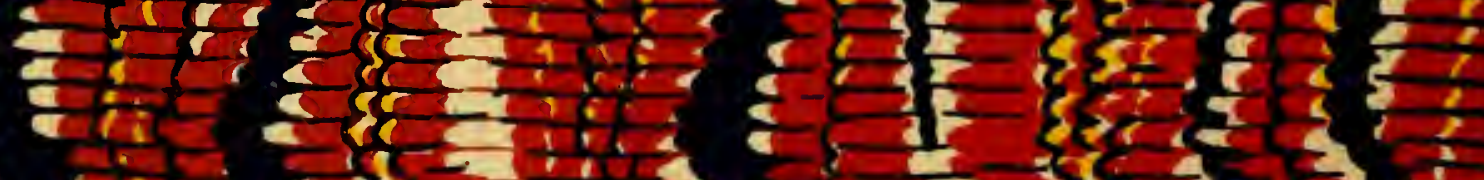

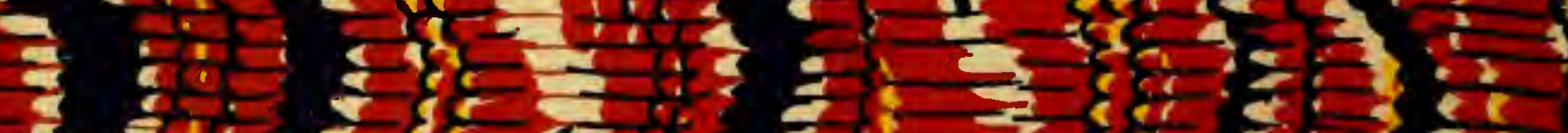

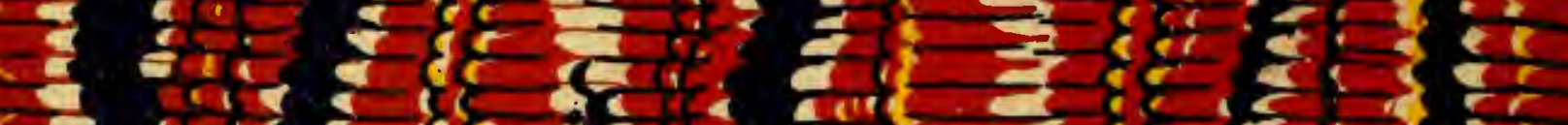

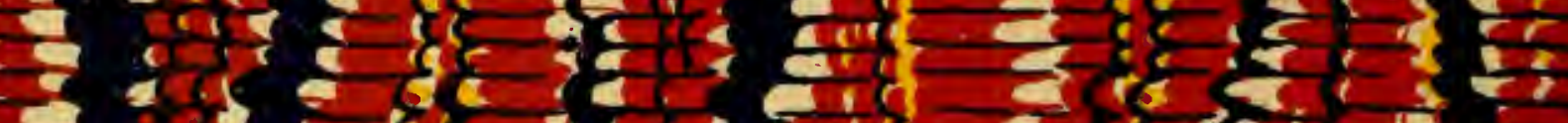

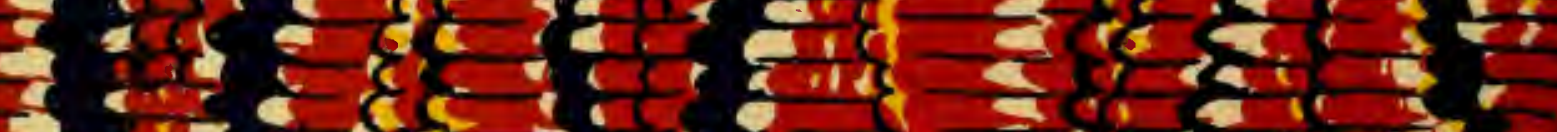

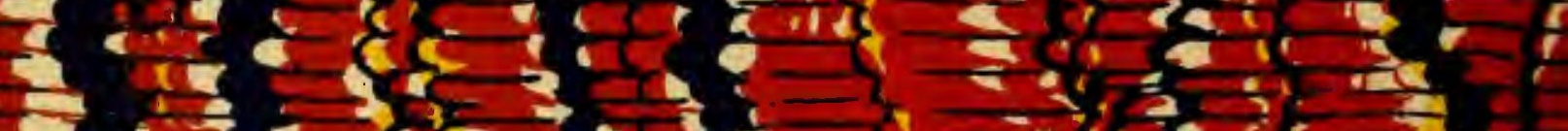

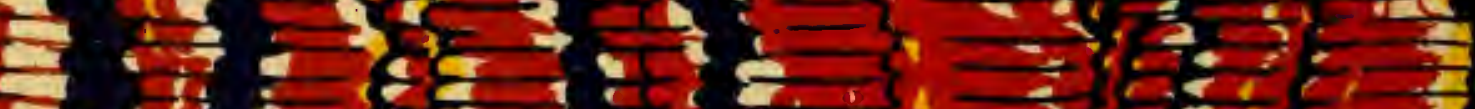
E हi है

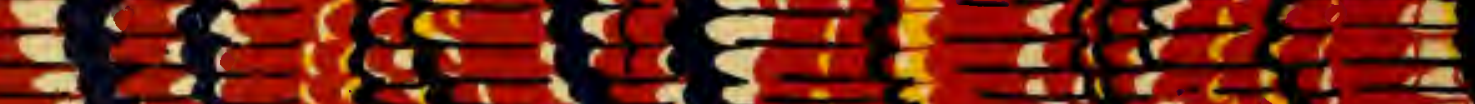

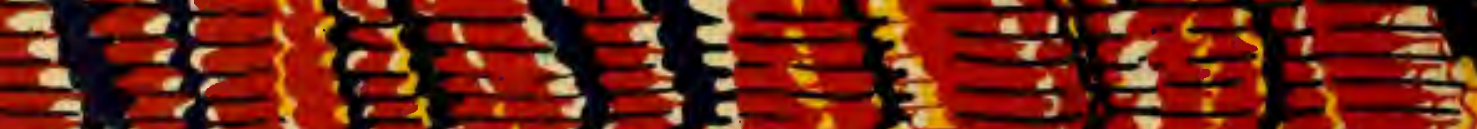

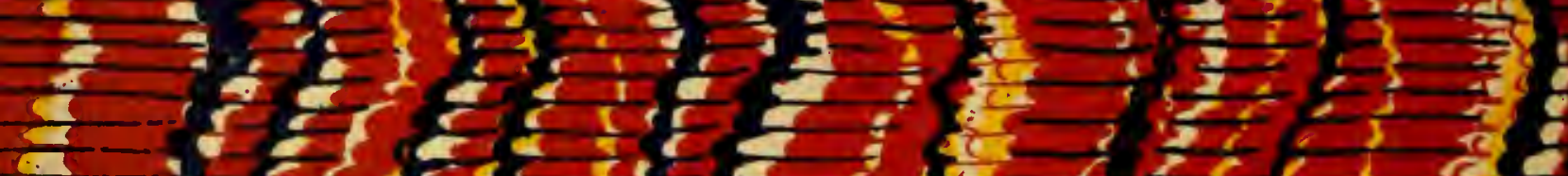

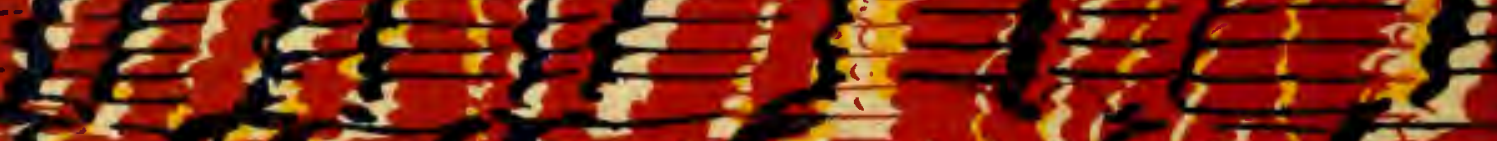

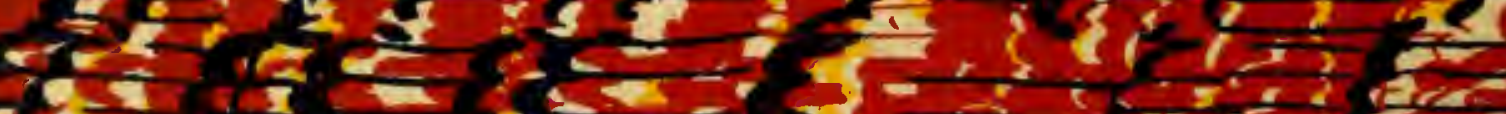

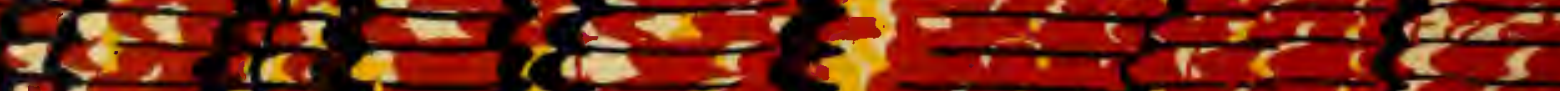

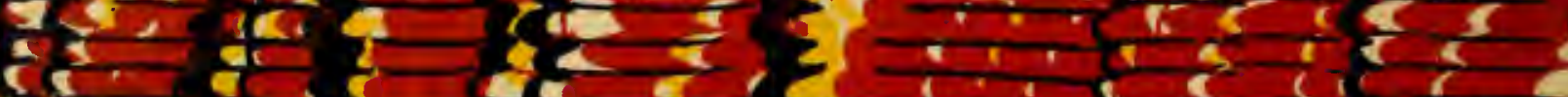

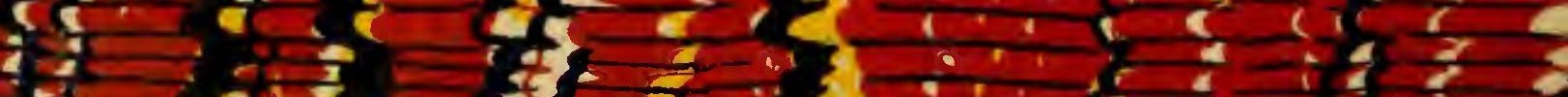

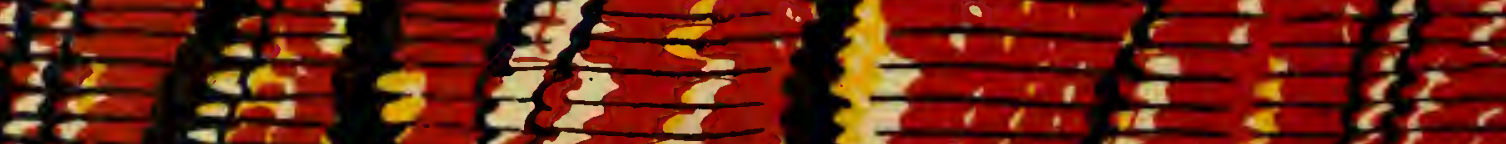




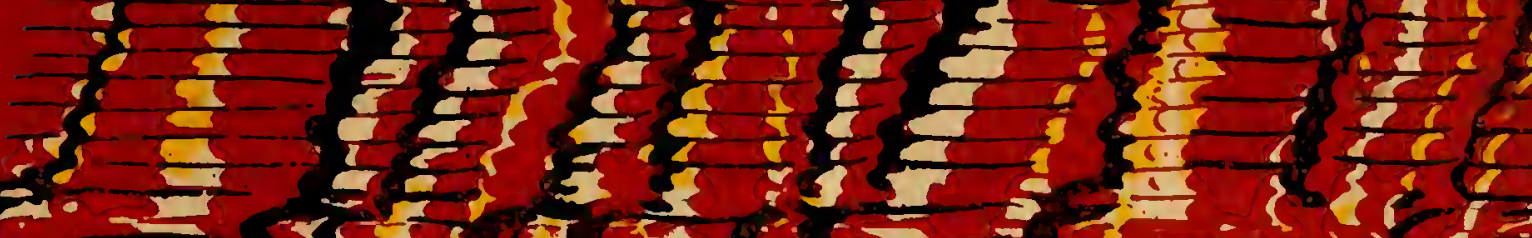

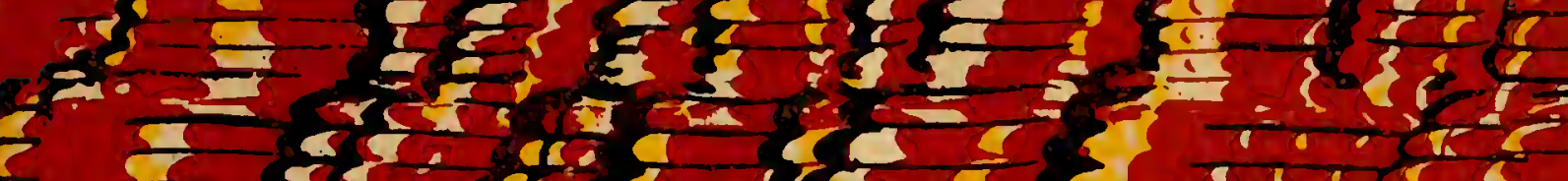

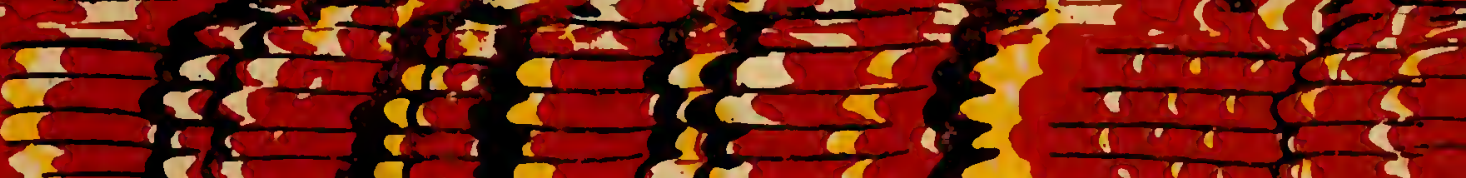

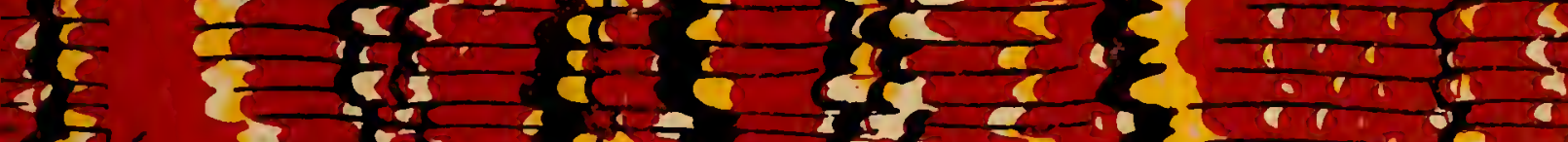

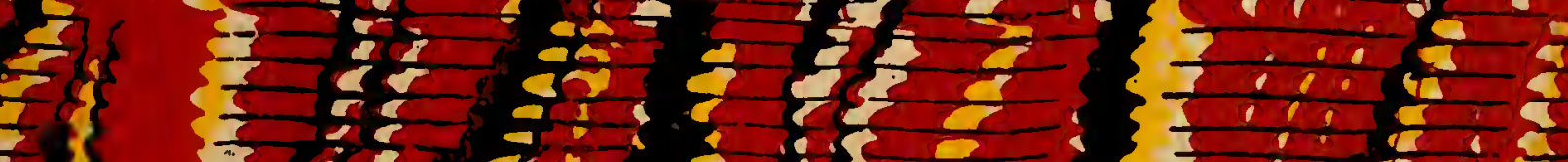

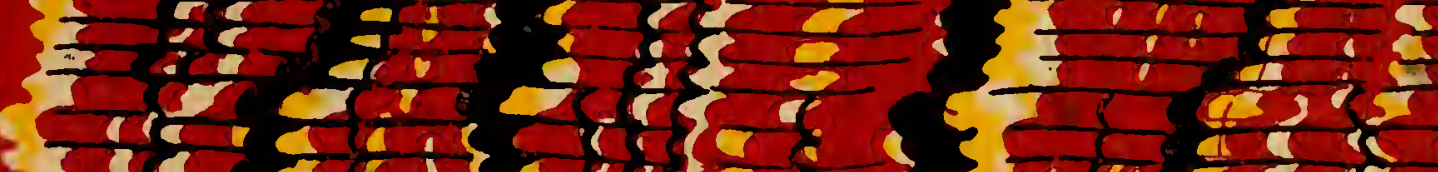

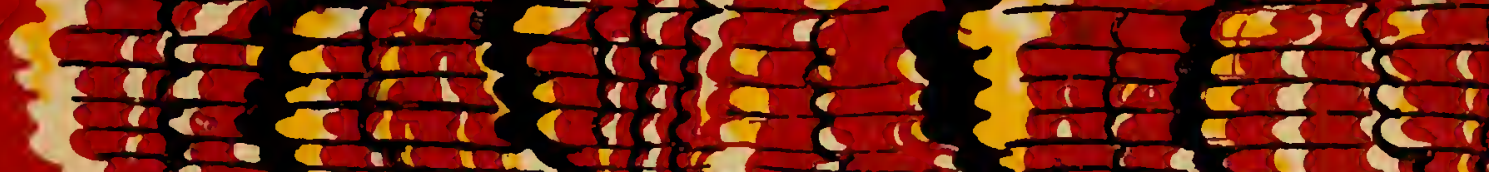

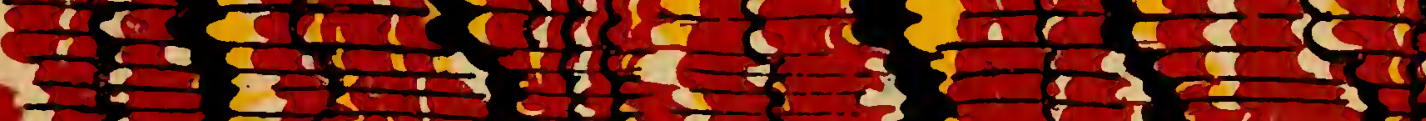

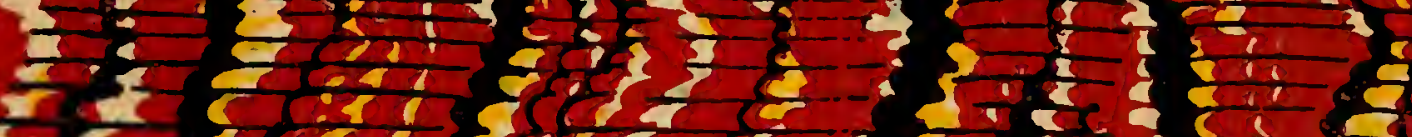

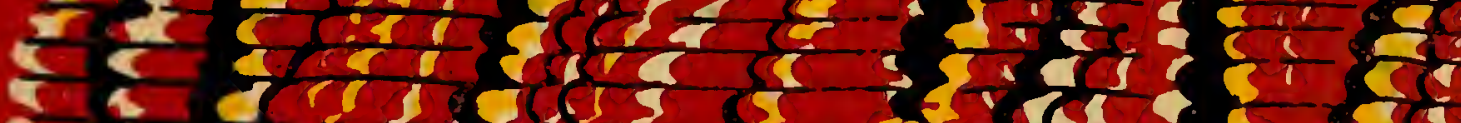

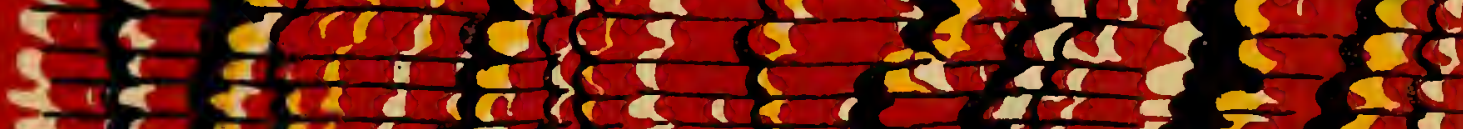

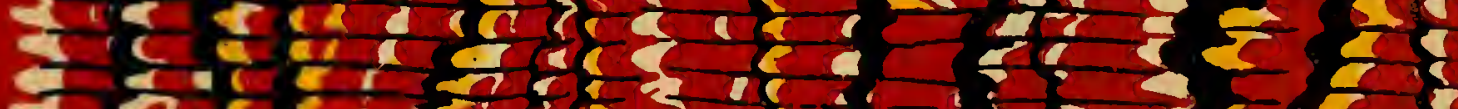

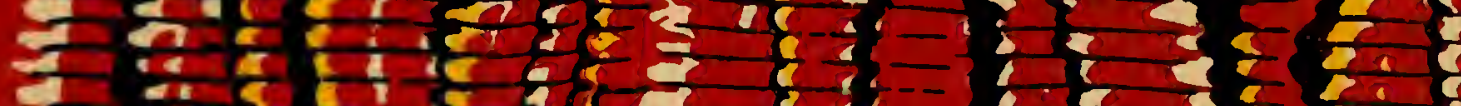

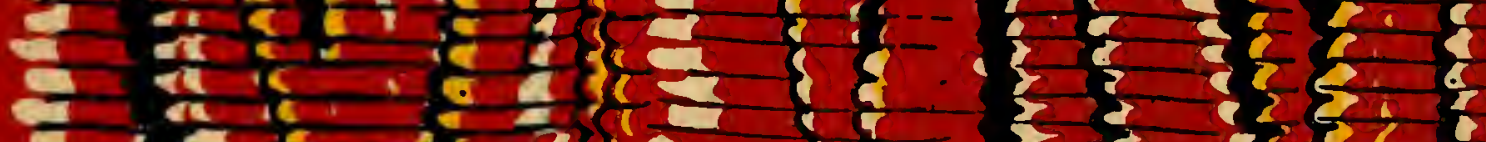

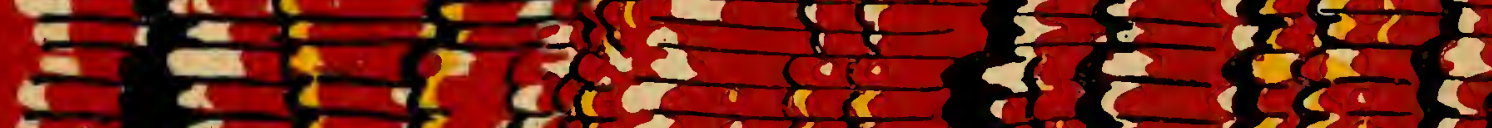
ह.1 5 is

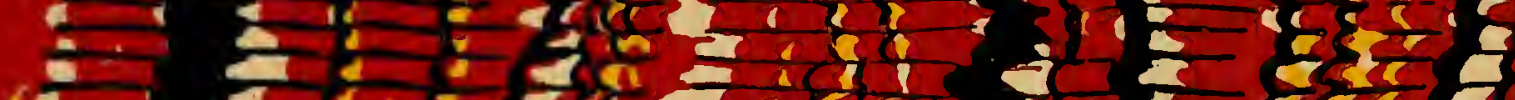

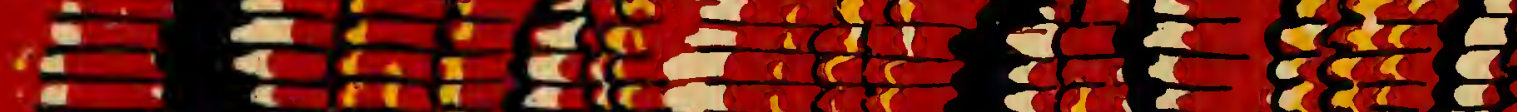

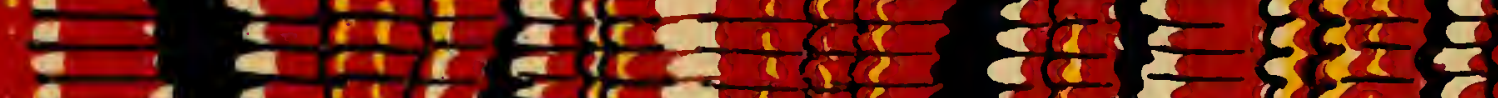

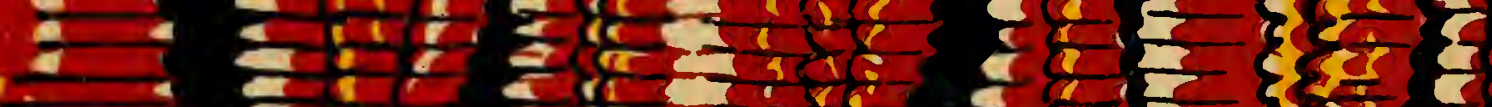

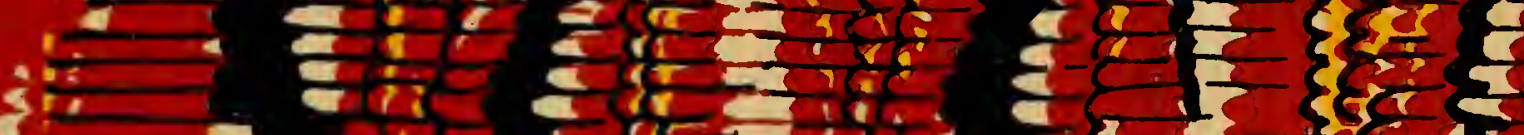

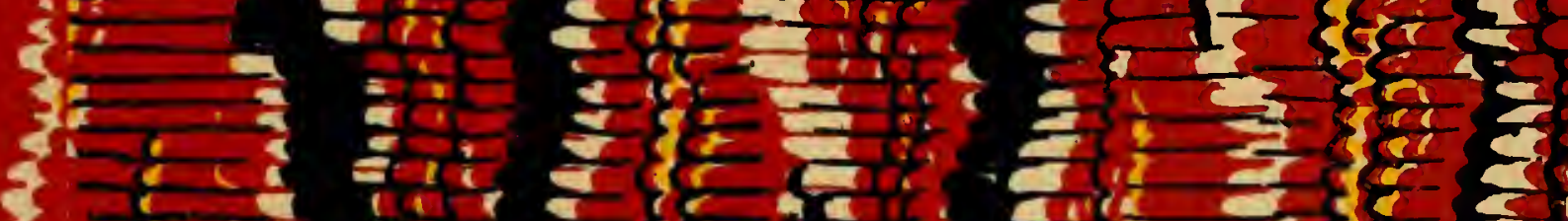

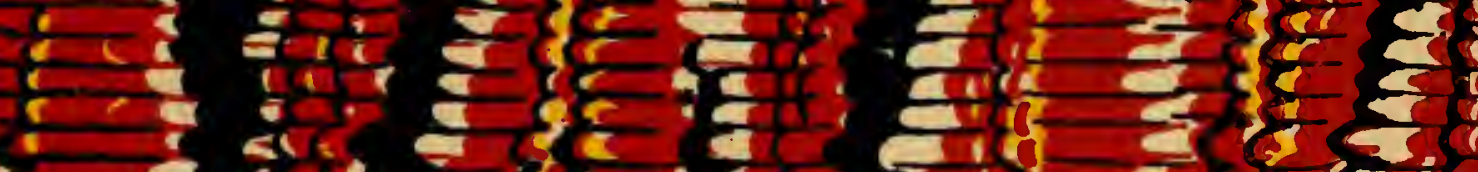
$1-2$ a

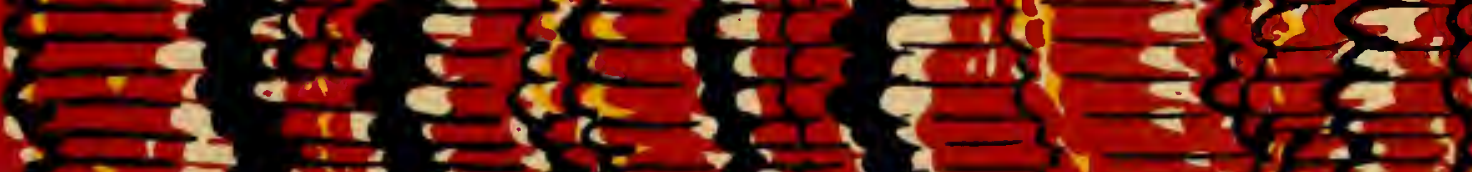

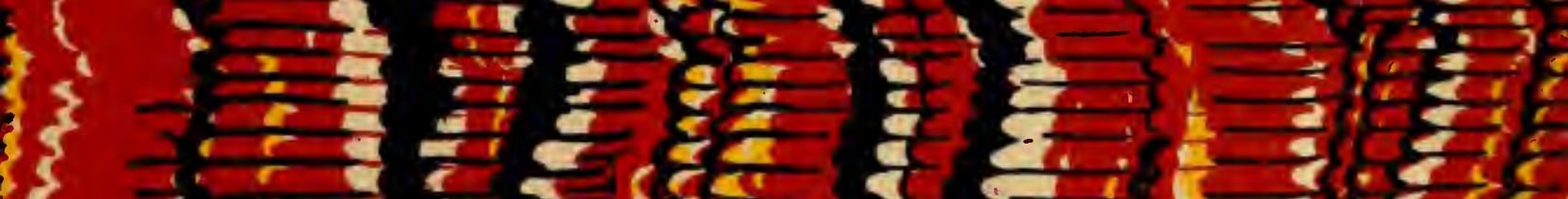

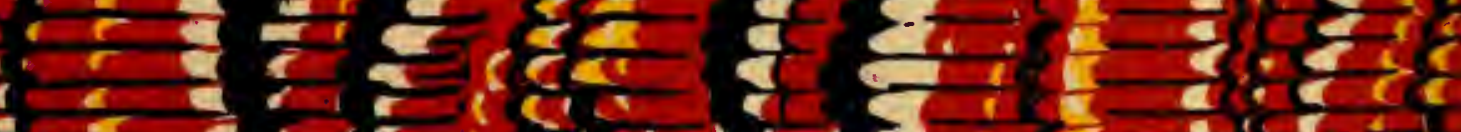

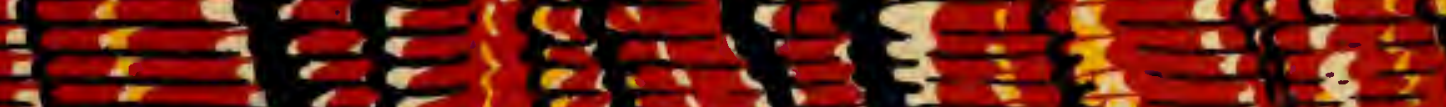

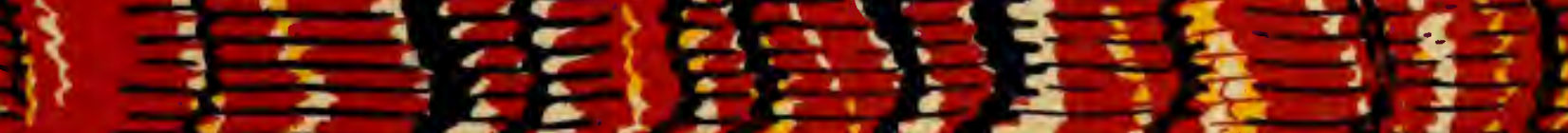

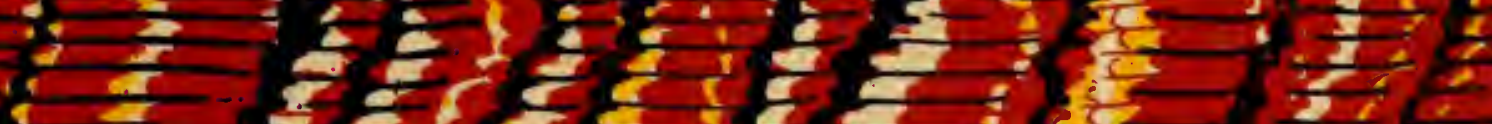

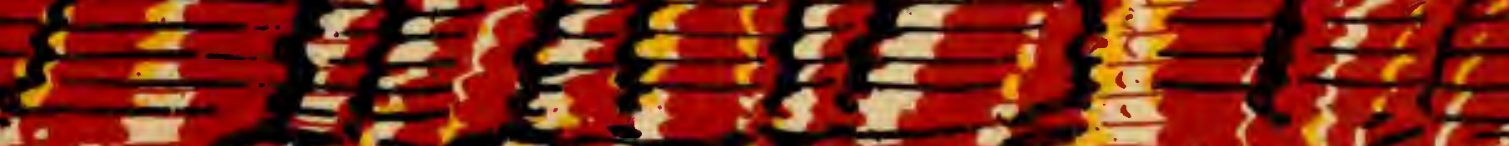

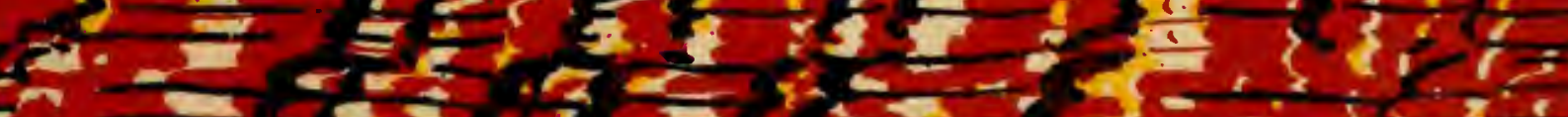

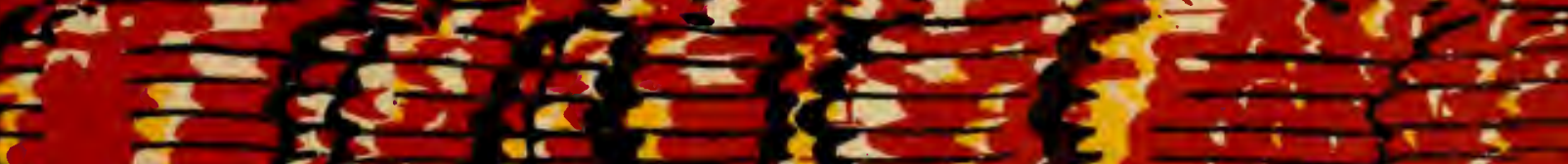

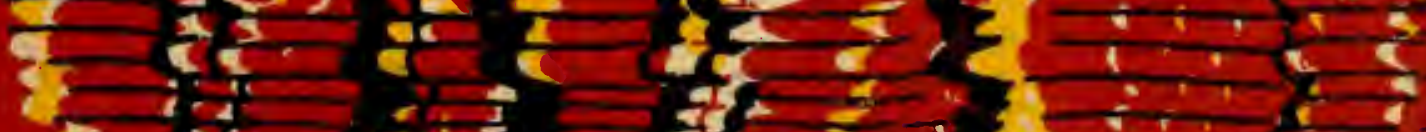

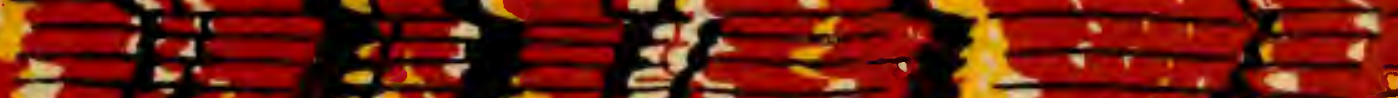





1. Report on tho Starfishes of the vest Indies, Morida, and Brazil, including those obtrined by Bahama Expedition from the University of Iowa in 1893.

Bul]. of the State University of Iova.

Bul]. from the Laboratories of liat. Hist. VII, No. I. pp. 3-232. Harch, 1915. pls. $I-X X I X$. 





\section{BULLETIN OF THE STATE}

\section{UNIVERSITY OF IOWA 33}

\section{BULLETINS FROM THE LABORÀTORIES OF NATURAL HISTORY}

\section{Report on the Starfishes of the West Indies, Florida, and Brazil}

INCLUDING THOSE OBTAINED BÝ BAHAMA EXPEDITION FROM THE UNIVERSITY OF IOWA IN 1893

BY

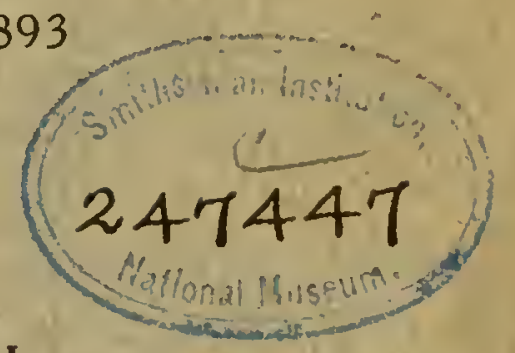

ADDISON EMERY VERRILL PROFESSOR EMERITUS, YALE UNIVERSITY NEW HAVEN. CONNECTICUT

PUBLISHED BY THE UNIVERSITY, IOWA CITY

ISSUED TWENTY-ONE TIMES DURING THE ACADEMIC YEAR: MONTHLY FROM OCTOBER TO JANUARY, WEEKLY FROM FEBRUARY TO JUNE. ENTERED AT THE POST OFFICE AT IOWA CITY AS SECOND CLASS MAIL MATTER 


\section{1}

-
4
4
4

a.

$\operatorname{lin}_{0 \rightarrow 1}-1$<smiles>C1CCCCC1</smiles>

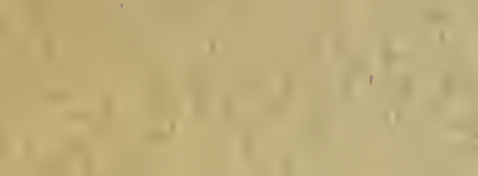

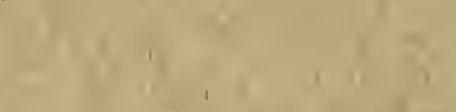

$\left(x^{2}+2,14 x=3\right.$

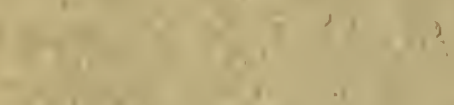




\section{BULLETINS FROM THE \\ LABORATORIES OF NATURAL HISTORY}

\section{EDITORIAL STAFF}

Charles C. NUtTING - - - - Zoology

GEORGE F. KAY - - - - - - Geology

BOHUMIL SHIMEK - . - . - - Botany

\section{CONTENTS}

Report on the Starfishes of the West Indies, Florida, and Brazil, including those obtained by the Bahama expedition from the University of lowa in 1893.

AdDISON EMERY VERRILL, Professor Emeritus, Yale University

PUBLISHED BY THE UNIVERSITY IOWA CITY, IOWA

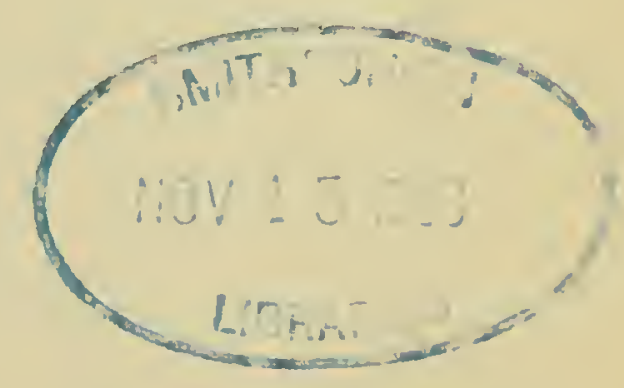


Since several years have elapsed since the publication of the last report on material secured by the Bahama Expedition of 1893 from the State University of Iowa, it has been deemed advisable at this time to give a list of papers in which the results of the expedition are discussed, together with the full titles, authors and dates of issue.

Contribution to the anatomy of the Gorgonidae, together with observations on living specimens. Pages 97-160, and 10 plates. C. C. NuTTING. Bull. Lab. Nat. Hist., S. U. I., Vol. I, No. 2. Nov., 1889

(This paper was based on material secured during a preliminary Expedition to the Bahamas by the author in 1888 , and therefore should find a place here.)

Narrative and preliminary report of the Bahama Expedition. 251 pages, and 20 full-page illustrations. C. C. NUTTing. Bull. Lab. Nat. Hist., S. U. I., Vol. III, Nos. 1 and 2. Jan., 1895

The mollusks and brachyopods of the Bahama Expedition of the State University of Iowa. 20 pages, and 1 plate. WM. H. DALL. Bull. Lab. Nat. Hist., S. U. I., Vol. IV, No. 1. Dec., 1896

Notes on the Hymenoptera collected by the Bahama Expedition from the State University of Iowa. 4 pages. William H. Ashmead. Bull. Lab. Nat. Hist., S. U. I., Vol. IV, No. 1. Dec., 1896

Report on the fishes eolleeted by the Bahama Expedition, of the State University of Iowa, under Professor C. C. Nutting. 20 pages. 4 plates. SAmuel Garman. Bull. Lab. Nat. Hist., S. U. I., Vol. IV, No. 1. Dec., 1896

Report on the Actinaria collected by the Bahama Expedition of the State University of Iowa. 25 pages, 3 plates. J. PlayfaIr McMurrich. Bull. Lab. Nat. Hist., S. U. I., Vol. IV, No. 3. June, 1898

The Brachyura of the expedition to the Florida Keys and the Bahamas in 1893. 65 pages. 9 plates. Mary J. Rathbun. Bull. Lab. Nat. Hist., S. U. I., Vol. IV, No. 3. June 1898

Report on the Ophiuroidea collected by the Bahama Expedition in 1893. 88 pages. 8 plates. A. E. VERrmL. Bull. Lab. Nat. Hist., S. U. I., Vol. , No. 1. Sept., 1899

American Hydroids. C. C. Nutring. Smithsoniau Institution, U. S. Nat. Museum, Special Bulletin No. 4, Part 1, issued 1900; part 2, issued 1904; part 3, issued 1915

(The writer, in undertaking to prepare this monograph, agreed to publish in it all descriptions of hydroids secured by the Bahama Expedition instead of issuing a separate Report on that group).

West Indian Starfishes found at a dcpth of 40 fathoms or less, including a report on material secured by the Bahama Expredition from the State University of Iowa. 230 pages, and 29 plates. A. E.

Verrill. Bull. Lab. Nat. Hist., S. U. I. Vol. , No. , 1915

Descriptions of about 70 new species of marine invertebrates from the Bahama expeditiou collections are found in the papers listed above. Some important groups, such as the Echinoidea, Vermes, and Corals are still to be reported on; but it is hoped that the series will be complete at a reasonably early date.

The material upou which these papers are based is in the museum of natural history of the University.

C. C. Nutting 


\section{INTRODUCTION}

That portion of this memoir relating to the special collection of the Bahama Expedition was nearly completed and the plates were made more than ten years ago, but its publication was delayed for several reasons, but largely because of the desirability of publishing, in advance of it, a much more extensive work, by the writer, on the starfishes of the North Pacific coast of America (Harriman Series) then in type, and in which the classification and many of the families and genera are revised.

Unavoidable and unexpected delay of the larger work had likewise delayed this. In the meantime, owing to the lack of any general work on the shallow water starfishes of the West Indies, and to the very scattered and unsatisfactory condition of the literature relating to them, it has been thought desirable to enlarge the report so as to include descriptions of all the families, genera, and species known to occur in the West Indian fauna, in waters less than 150 fathoms deep.

The West Indian faunal region is here extended so as to inelude the entire region from northern Florida to Rio de Janeiro, Brazil, and to include, also, the Bermudas and the whole of the Gulf of Mexico.

As compared with other tropical seas, the West Indian starfish fauna is very poor in littoral and shallow water species. It is rarely that more than twelve to fifteen species can be found by careful shore and reef-collecting at any one place.

Professor Clark (1898), after two seasons of shore and reef collecting of the echinoderms at Jamaica, enumerated only fourteen species of starfishes, although he visited both sides of the island, as well as outlying reefs. The entire number of littoral and very shallow water species probably does not exceed twenty to twenty-two over large areas.

This is not more than one-half or one-third the number to be found in many other similar regions. 
At depths of 100 to 1,000 fathoms, however, the starfishes are very numerous, both in species and individuals.

The most prolific zone for starfishes, as well as for most other groups, is on the continental border in 100 to 500 fathoms.

The Bahama Expedition dredged at a number of localities between 100 and 200 fathoms, especially at the famous crinoid ground, off Havana, which is a locality very favorable for marine invertebrates of many kinds. Therefore, the collection obtained includes an unusual number of species, considering the small number of dredgings made, and the smallness of the equipment, as compared with that of the "Blake" or the "Albatross."

A few of the more common West Indian and conspicuous shallow water starfishes were mentioned by the early writers, such as Marcgraft (1648); Sloane (1725); Linck (1733); Seba (1761), and others.

This was especially the ease with the very large and conspicuous species, the "large warted starfish" of Brown, 1756, now known as Oreaster reticulatus, which is very common in many places in very shallow water, and therefore sure to attract the attention of the most casual observers.

Yet the number of species actually known to occur in the West Indies was very small up to the period of Gray (1840) and of Müller and Troschel (1842).

Linné referred only two or three of his species to the West Indies and some of those doubtfully. Lamarck (1816) recognized only two or three as West Indian. Thomas Say (1825) recorded six species from the southern coast of the United States, five of which he described as new. All of these, except two, are also West Indian species.

Gray, 1840, gave the West Indian region as the source of eight of his species. Mïller and Troschel (1842) recorded but five as West Indian, though they described others from this fauna whose origin was unknown.

The first attempt to give a critical synopsis of the West Indian species was made by Prof. Christian Lütken, ${ }^{1}$ a most careful

1 Dr. Christian Frederik Lütken, professor of the University of Copenhagen; lieutenant in the war of 1849-50; died February 6, 1901, aged 73 years.

His works on the starfishes and ophiurans of northern Europe, Green- 
writer, in 1859. He then described with care thirteen species, in the Museum of Copenhagen, mostly from the Lesser Antilles. Six were described as new, mostly with doubt. At least four of these proved to be synonymous with those of Gray and other previous writers, who had poorly described them. His careful descriptions are, however, invaluable for the determination of most of the early known species, and mark an era in work of this kind.

In 1867 the present writer published a faunal list of West Indian species, for comparison with that of the Panama region. This list included twenty-four nominal species, but at least five of these have since become synonymous. On the other hand, two or three previously described species were omitted. Thus the number of species of this fauna actually known at that time was about twenty.

The beginning of dredging in somewhat deep water was made by Pourtales in 1867 and 1868 , but only one additional species of starfish was then added by him. ${ }^{2}$ Subsequently, these investigations were carried on by the "Bibb," in 1869, and the "Hassler" in 1872, under the direction of Pourtales, and in 1872, under Dr. Wm. Stimpson by the "Bibb" and "Bache." But no separate lists of the starfishes taken in those years has been published. Some are included in the "Revision" by Perrier, 1875 and 1876 (see Bibliography); others in his 1884 report on the Blake starfishes.

Mr. Alexander Agassiz carried out his extensive dredgings in the Caribbæan Sea and Gulf of Mexico, etc., on the "Blake" in $1877,1878,1879$, and 1880. About 350 stations were occupied by the Blake.

These explorations ${ }^{3}$ added numerous species of starfishes to the fauna, not only from great depths, but also many from comparatively shallow water.

The starfishes thus obtained by Agassiz were described by Per-

land, and both coasts of tropical America are classical and indispensable. He also wrote on fishes, ascidians, actinians, and other subjects.

For many years he was a most esteemed correspondent of the writer.

2 Catalogued by Agassiz as Pteraster militaris, now called $P$. caribbaus Perrier.

${ }^{3} \mathrm{~A}$ rery complete and interesting account of these explorations is given by Mr. A. Agassiz in "Three Cruises of the Blake." Vols. I, II. $18 s 8$. 
rier in several articles from 1880 to 1894 , but most were brought together in his memoir of 1884 .

Dredging operations of great extent were carried on by the U. S. Fish Comm. steamer "Albatross," in the West Indian region during the winters of 1884,1885 , and $1886 .{ }^{4}$ Many species of starfishes were then obtained, including a considerable number of new species. But those collections have not yet been systematically reported upon, though the writer described and figured a number of the species in 1899.

According to Mr. A. Agassiz (1888, p. 4), the Blake took 54 species of starfishes, of which 46 were considered new species by Perrier. The actual number has since proved to be slightly larger.

The Bahama Expedition, from the University of Iowa, dredged mostly in waters less than 200 fathoms deep. The most interesting were off Havana, on the crinoid grounds, where a number of additions to the starfish fauna were taken. Others of interest were from off E. Florida, on the "Pourtales Plateau." The total number of species taken was about thirty.

In consequence of these more modern dredging expeditions the number of species of West Indian shallow-water starfishes, living in less than 150 fathoms, has been very much increased, while the deep-water species have become even more numerous.

I have had opportunity to examine most of the types of the "Blake Expedition" starfishes, described by Perrier, and also many of those taken in the West Indies by the Albatross. But I have not had opportunities to make any thorough studies of the latter as a whole, and, therefore, can not give any useful statement as to the number of additions to the fauna contained in them. Some of the species from the Albatross explorations were revised, and a number of new species were described and figured by me in 1899. (Revision of Genera and Species of Starfishes, see Bibliography.)

At present about 125 species are known to me from that general faunal region, or from Florida to Brazil. Of these about 42

4 Lists of all the dredging stations occupied by the Albatross, Blake, and other U. S. vessels up to 1887 , with physical data, were published by Sanderson Smith, in the Annual Report of the U. S. Fish Commission, for 1886, pp. 873-1014. 
species have not been taken in less than 150 fathoms, and several are still undescribed.

Some of the West Indian shallow-water species have a wide range. A few range from Florida to the Abrolhos reefs, Brazil, or to Bahia. Two or three are said to be found on the West Coast of Africa, or at the Cape Verde Islands. Four reach Bermuda. None are identified with those of Panama, though some are closoly related. Among the deep-water species a few have been taken also off the eastern coast of the United States, north of Cape Hatteras, and three or four are thought to be identical with East Atlantic species from similar depths. Yet most of the species are peculiar to this fauna.

Very little is known concerning the starfishes to be found on the extended coasts of the Gulf of Mexico, beyond the coasts of western Florida and Alabama. Mr. Ives has listed several species from Vera Cruz and Yucatan. Two are peculiar to Vera Cruz, so far as known. Yet there are more than two thousand miles of that coast line about the marine fauna of which we know almost nothing.

That coast is almost everywhere sandy, and therefore not favorable to many shallow-water invertebrates, except in sheltered localities.

It is known, however, that several of the Florida species reach Vera Cruz and Yucatan; others reach Colon. I can now add that one species (Astropecten americanus), common at moderate depths north of Cape Hatteras, occurs at similar depths on the northern coast of Colombia.

The Brazilian species are here included, because several, or the majority, are identical with West Indian and Florida species. The Brazilian starfishes have been listed by Mr. Richard Rathbun, 13 species (1879), and later by Ludwig, 1882. At least nine or ten of the Brazilian species occur also in the West Indies.

In this report all those species which are known to have been obtained in less than $\mathbf{1 5 0}$ fathoms are included, though a number of them really belong to the deeper water series, but find their upward limits in 100 to 150 fathoms. Doubtless other deepwater species will hereafter be found at such depths, especially the young. A few other deep-water species have been included for the sake of comparisons with their shallow-water allies. 
It is proposed to include, at the end, a special list of the other deep-water species (about 40) not reported upon, for the sake of completeness.

Thus the systematic part of this report will include about 82 species and subspecies, nearly all of which are redescribed in detail, with their known distribution, etc.

Comparatively few, even of the shallow-water species, have ever been figured. Therefore some of them, though not new, have been figured in this report.

The drawings of structural details are by A. Hyatt Verrill, and also most of the photographs.

\section{Class ASTERIOIDEA MORPHOLOGICAL FEATURES}

The Asterioidea ${ }^{5}$ have a polygonal or star-shaped body, in which the rays are direct prolongations of the body itself, and contain extensions of the body-cavity and more or less of the viscera, especially one or more pairs of gonads and a pair of digestive glands; generally, also, a lobe of the saccular stomach.

The actinal or ventral side of the disk and rays has deep, radial, ambulacral grooves, extending to the tips of the rays. The roof of the groove is supported by two rows of ambulacral ossicles, arranged like rafters, or in close, inverted, V-shaped pairs of plates or bars, between which are rows of pores for the passage of the tubular ambulacral feet or "podia," which are usually terminated by a muscular sucker, but are pointed in the suborder Paxillosa.

In the middle line of each ray and external to the ambulacral plates are situated the radial nerve and blood-vessel; and deeper within, the median radial "water-tube" or ambulacral tube. The radial water-tube supplies water to the podia through the medium of muscular ampullæ situated internally, above the ambulacral plates. Usually there are two of these to each podium, but in Echinaster, Ctenodiscus, and some other genera there is only one.

The grooves are bordered on each side by a row of plates called adambulacral, which always bear spines.

5This spelling of the name is preferred because it is derived from $A s$ terias (not from Aster.) 
The mouth is central, dilatable, and surrounded by soft membrane. The so-called jaws are merely the adoral ambulacral and adambulacral plates, more or less modified and coalesced. The "teeth" are only slightly modified adambulacral spines.

The stomach is very saccular and usually evertible. It usually has a lobe and a pair of digestive glands extending into the cavity of each ray, but in the case of some multiple-rayed species (Heliaster), it has lobes corresponding only to the primary five rays. In this case the five stomach-lobes do not enter the rays, but the five pairs of digestive glands do. In a few slender-rayed genera, also, the stomach is confined to the disk. The intestine is rudimentary or abortive, and not functional in most cases; usually there is a median dorsal nephridial or "anal" pore, mainly for the discharge of the secretions from a lobulated gland.

The respiration is partly dermal, but especially by tubular dermal outgrowths, called papulæ. The madreporic plate is dorsal, usually single, but sometimes two or more are present in autotomous species. The rays terminate in an enlarged apical or ocular plate, carrying an ocellus.

The skeleton is made up of large numbers of ossicles and plates of various kinds, mostly articulated so as to be more or less movable, giving flexibility, both to the rays and to the disk, though in some species (e. g. certain Goniasteridx) the flexibility is slight, except at the tips of the rays.

The external skeletal plates are classed as dorsal or abactinal; marginal; interactinal; adambulacral; ambulacral; oral; and ocular or apical. The dorsal plates are very diverse in form and arrangement. They may be irregularly reticulate, tesselated, or imbricated. They may form regular radial rows; sometimes they are abortive, or nearly so. They are concealed by a thick dermis in certain genera.

The dorsal plates, like the marginals and interactinals, commonly bear spines or small spinules, but they may be covered with granules, or with a smooth soft integument, or even appear quite naked, being then covered only with a thin membrane.

These plates and their armatures of spinules take several special names, according to their forms and structure, and are often characteristic of special genera and families and higher groups. 
When they become columnar or of hour-glass shape, and have the summit covered with a radiating cluster of small slender spinules, they are called paxillæ. These are the most typically formed in Astropecten, Luidia, and allied genera, and are characteristic of the suborder Paxillosa. ${ }^{6}$

In nearly all the families there are two rows of specialized plates on each side of each ray, known as superomarginal and inferomarginal plates. These are often the largest and most conspicuous of all the plates, especially in the Phanerozona, such as Astropecten, Goniaster, ete. In other cases both rows are much reduced in size and are not easily distinguished, as in some of the Asteriidx. Or only the upper row may be reduced and indistinct, as in Luidia. Rarely one or both rows are abortive in certain deep-sea genera. Secondary intermarginal rows of plates are often interpolated between the marginal rows in some families.

Between the inferomarginals and the adambulacral plates there may be one or more rows of plates called interactinals. The first and most important of these is next the inferomarginal row, and is called the peractinal row in this article. It may extend nearly or quite to the tip of the Ray. The other rows are called subactinal rows, and may be much shorter and later formed. All these interactinal rows may be lacking in many genera, or they may be rudimentary and spineless.

They appear later in development than the marginal plates, and the new ones are not formed next the ocular plates, as are the marginals.

Pedicellariæ of one or more kinds are generally present, but are rare or entirely lacking in certain families, such as the Solasterida, Echinasterida, Pterasteridce, and in some genera of other families. Their uses are imperfectly known. One use it to keep the body free from dirt and parasites.

These eurious organs are not found in other classes of Echinoderms, except in the Echinoidea. In the latter they are commonly mounted on long stalks and generally have three valves sometimes four or more or only two.

In the Asterioidea they are usually sessile, but in the order

${ }^{6}$ For various other special forms and their names, see below, under Phanerozona and Valvulata. 
Forcipulosa they have very short pedicels, and they are most frequently bivalved.

They are of several different types, which are commonly characteristic of the orders and families, and often of the genera.

Sometimes there may be bivalved, trivalved, four-valved, and five-valved ones on a single specimen, as in Dermasterias imbricata. In some cases they are not really valvular, but consist of several movable spinules, arranged in convergent groups or opposed rows. The sessile valvular forms are generally situated over a pore, penetrating a plate, for the passage of nerves, etc.

Some of the special forms are described below, under the several orders.

In nearly all species there are numerous small, soft, tubular outgrowths from the body-wall, called papulce, serving for respiratory purposes. They may be in large groups, especially between the dorsal and lateral ossicles, or stand singly, or they may occur only in special areas. Rarely they are branched, as in Luidia.

Most shallow-water starfishes that have been studied in this respect have a free-swimming, bilateral larval form, known as a brachiolaria. A considerable number carry their eggs and young till they develop the starfish form. These have an abbreviated metamorphosis. The two methods may occur in different genera of the same family (e. g., Asteriidce).

The embryology of the deep-sea species is unknown in most cases, and may be diverse, or even more abbreviated.

\section{CLASSIFICATION OF ASTERIOIDEA.}

In this report I have adopted the division of the class into three large orders, viz. :

I. Forcipulosa or Forcipulata.

II. Spinulosa, with suborders, Avelata and Velata.

III. Phanerozona.

The last has three suborders, considered order's by some writers, viz. :

I. Valvulosa or Valvata.

II. Notomyota Ludwig (as an order).

III. Paxillosa. 
Order Forcipulosa Verrill or Forcipulata Perrier.

Stellerida forcipulatc Perrier, Mem. Etoiles de Mer, pp. 166, 188, 1876.

Forcipulata Perrier, Exped. Sci. Trav. et Talisman, p. 27, 1894.

Asteries Ambulacraires ViguiEr, Squellette des Stellerides, Arch. Zoöl.

Exper., VII, p. 93, 1878.

Cryptozonia (pars) Sladen, Voy. Chall., xxx, pp. xxxiv, 397, 1889.

Adetopneusia (pars) Sladen and Leptostroteria (pars), op. cit., p. xxxiv. Forcipulosa Verrill, op. cit., p. 24, 1914a.

In this order the form is always stellate, often with long rays, commonly five, but often multiple. Ambulacral plates, except the orals, are usually short and closely crowded (leptostroterial), but not in Brisingida. The proximal pair is elongated and, except in Pedicellaster and a few others, forms the inner end of the jaw. Ambulacral feet are generally arranged in four rows; but in two rows in Pedicellasteridce, Brisingida, and Zoroasteridoe. In certain large species of Pisaster there may be more than four rows.

Aside from the ambulacral and adambulacral plates, the skeleton of the rays consists of five fundamental or primary rows of ossicles, viz., the median dorsal or carinal; the two siperomarginals; and the two inferomarginals. The latter may or may not be confined to the ventral side.

The ossicles of adjacent rows may be articulated directly by their lobes, or small, simple connecting ossicles may intervene.

This simple or primitive type of skeleton is found in Coronaster briareus (see pl. ix, fig. 4) and some other genera, especially when young.

In most cases more or less numerous ossicles or rows of ossicles are interpolated during growth between the five primary rows, either above or below, or between the marginals, thus giving rise to many different styles of skeleton in the more complex genera.

The carinal or median dorsal plates usually remain distinct, but are often small and not easily recognizable. The two marginal rows are nearly always easily recognizable, though small, and they generally bear spines larger than the dorsals. They never form a stout margin, as they do in the Paxillosa.

Interactinal plates are various. Usually there is at least one row, the peractinals, but these are often small and spineless and sometimes are lacking. In other genera there may be several rows of spiniferous interactinals. 
The Forcipulosa, as the name implies, are specially characterized by the possession of forcipate pedicellariæ, not found in other orders. Two forms of pedicellariæ are nearly always present, except in the young.

The minor or forcipulate pedicellariæ, peculiar to this order, generally form wreaths or large or small clusters on the spines, but they may also occur, either singly or in clusters, on the integument of the dorsal or lateral plates, on the papular areas, and in other situations. Their two blades are prolonged proximally and crossed, with muscles attached to the ends, so that they can open and shut like forceps or scissors. Their valves are concave and are usually armed with denticles.

The major or forficulate pedicellariæ are generally ovate or lanceolate, sometimes wedge-shaped, stone-hammer-shaped, lyrate, or spatulate. The tips may be acute, plain, flat or denticulate.

They are mostly dermal, but may also occur on the ventral and oral spines, or along the inner edges of the grooves, or attached to pedicels in clusters within the grooves, or even on the pedicels of the ambulacral feet. They may be of several sizes and forms on one specimen.

Certain species of Asteriidce, Coronaster, etc., have a peculiar very large form of dermal pedicellariæ, often as thick as the spines, in which the broad valves terminate in a series of curved denticles, so that when closed the valves resemble a pair of clasped hands, or better still, a pair of clasped feet of a cat, with the claws protruded. These may be called felipedal or unguiculate. (See pl. ix, fig. 4c.)

FAMILIES AND SUB-FAMILIES OF FORCIPULOSA.

This order now includes the following families and sub-families:

I. Family AsteriId 2 .

Subfamilies Asterinna; Stichasterinæ; Pycnopodinæ;

Heliasterine.

II. Family ZoroAstenide.

III. Family Pedicell $\Lambda$ steride.

IV. Family Brisingidæ.

Subfamilies Brisingine; Labidiasterinæe (Type, Labidiaster Lutk.). 
The first three families are represented in depths less than 150 fathoms, though all except the first family are essentially deepsea groups.

\section{Family AsteriId Gray (emended).}

Asteriida GraY, Ann. \& Mag. Nat. Hist., vi, p. 178, 1840; Synopsis, p. i, 1866. Perrier, Revis. Stell., Arch. Zoöl. Exper. et Gen., iv, p. 302, 1875; Mem. Etoiles de Mer, pp. 167, 198, 1876. Viguier, Squellette des Stellerides, pp. 93, 99, pl. v, figs. 1-10, 11-12, 1878.

Asteriido (emended) + Stichasteride Sladen, Voyage Chall., xxx, pp. 430, 560, 1889. Perrier, Exp. Trav. et Talisman, pp. 43, 105, 107, 128, 1894; Contrib. l'étude des Stellerides Atlan. Nords, pp. 25, 31, 1896. Verrill, Monog. Starfishes, North Pacific, pp. 27-44, 1914a (emended.)

Stellate starfishes, most often with five or six elongated rays; sometimes with a variable number of unequal rays in autotomous species; sometimes with numerous rays, increasing with age by the outgrowth of interpolated rays, as in Heliaster and in Pycnopodia. Madreporic plate generally single in five-rayed and sixrayed forms, but often two or more in those with a variable number of rays, due to autotomy or budding. Dorsal and actinal plates various in form and arrangement, most often reticulated. Odontophore usually formed of a single piece. Oral ambulacral plates elongated and forming the jaws. Those along the grooves become very short and compressed. Papulæ occur both on the actinal and dorsal sides. Ambulacral feet usually crowded in four rows, sometimes more. Pedicellariæ of two kinds are present. Dorsal plates generally bear spines or spinules, various in size and kind, and sometimes granules. They are never true paxillæ.

The minor pedicellariæ may be attached directly to the integument, either singly or in clusters, or to the spines, to the pedicels of the larger forms, to saccular dermal growths around the spines, to the inner edge of the ambulacral grooves, or rarely even to the ambulacral feet. They are most commonly attached by slender and sometimes long pedicels, and aggregated into wreaths or clusters attached to a contractile fold of dermis on the spines. They are often so abundant, in the wreaths around the dorsal spines, that they nearly or quite conceal the spines and integument in living specimens. In some cases they are attached in large numbers to large muscular dermal sheaths or 
sacks loosely surrounding the spines nearly or quite to the tips when extended in life. They often have a formidable array of minute sharp denticles, and are frequently very characteristic of species.

\section{Subfamily ASTERINA.}

Asteriidae (restr.) Sladen, op. cit., 430, 560, 1889. Perrier, 1894, pp. 105, 128 ; 1896, pp. 25-31.

Asteriince Verrill, op. cit., p. 42, 1914a.

The Asteriince are chiefly characterized by the more or less openly reticulated arrangement of the dorsal and lateral ossicles, especially of the dorsal ossicles, which are usually more stellate or lobulate and more slender than in the Stichaster group, and generally united either by the ends of the lobes or apophyses, or else by means of interpolated ossicles, thus allowing more flexibility in the rays, and larger papular areas. The dorsal plates may be in definite rows or irregularly reticulated.

The Stichasterince, on the contrary, are chiefly characterized by the more or less regular subtesselated or imbricated arrangement of the ossicles, both on the sides and dorsal surface of the rays, the ossicles themselves being larger, broader, and more rhombic, and usually united in more definite, longitudinal and transverse rows, with smaller and more regular intervening papular areas. In either group, as at present understood, the interactinal plates may have the regular serial and subtesselated arrangement.

The discovery of many new generic and specific types intermediate between typical Stichaster ${ }^{7}$ and Asterias, renders it difficult to define the limits of the two so-called families, typified by these genera.

The only West Indian genus that has been referred to the Stichasterinæ is Stephanasterias. To me this seems to be more nearly related to Leptasterias and therefore one of the Asteriinæ.

Genus Orthasterias Verrill.

Orthasterias Verrill, Starfishes North Pacific, pp. 168-185, 1914a.

Long-rayed diplacanthid starfishes with a small disk. Dorsal

7 The type of Stichaster is S. striatus $M$. and Tr. = S. aurantiacus of later writers. It is a Chilian species. 
skeleton consists of lobed, wide, subimbricated or contingent plates, arranged in three, five, or rarely more regular radial rows, and sometimes with extra interpolated ossicles; the rows are connected by transverse ossicles. The principal plates bear, on a central boss, large, isolated spines, usually making three or five longitudinal rows above the marginal rows.

Superomarginals are large, usually monacanthid, four-lobed; the descending lobe is large and usually joined directly to the inferomarginals.

The inferomarginals are strong, convex ossicles, each bearing usually two large spines.

Uusually there is one row of interactinal plates, with or without spines, closely united to the adambulacrals and inferomarginals; sometimes they are rudimentary and without spines. (Stylasterias.)

Papulæ are numerous and clustered.

The lateral and dorsal major pedicellariæ are large, and are usually of two or more forms. The larger are erect, wedgeshaped, stone-hammer-shaped, or ovate, with the tips of the valves wide and usually denticulate. Others are more slender, with the valves spatulate or narrowed in the middle and the tips unguiculate, with interlocking teeth. Others similar, or smaller, with acute tips, often occur on the adambulacral spines and margin. Type, $O$. columbiana $\mathrm{V}$.

This genus includes several large species on the North Pacific coast. Off the eastern coast of the United States one species (O. tanneri Ver.) is abundant at moderate depths, from south of Cape Hatteras to southern New England.

The subgenus Stylasterias Ver. (op. cit., p. 48, 1914a), was separated mainly because it has only rudimentary and spineless interradial plates, which are not visible without preparation.

The following West Indian species belong to this group or subgenus. The young of 0 . tanneri, when two or three inches across, have the same features.

Orthasterias SUBANGULOSA Verrill.

Asterias angulosa Perrier, Bull. Mus. Comp. Zoölogy, vol. ix, p. 3, 1881; Mem. Etoiles de Mer, p. 202, 1884 (non Müller.)

Orthasterias (Stylasterias) subangulosa Verrill, Starfishes N. Pacific Coast, pp. 168, 370, 1914a. 
Plate ii; figures 1, 2. Plate ix; figures 1, $1 a$.

The largest specimen has the radii $9^{\mathrm{mm}}$ and $66^{\mathrm{mm}}$; ratio, $1: 7.33$. This was from the Bahama Expedition, station 43, in 15 fathoms. The disk is small and has a very evident central pentagon of plates and spines. The rays are slender, somewhat angular, regularly tapered to subacute tips.

The dorsal plates form a conspicuous raised median carina, and a smaller dorso-lateral row on each side, well separated from the prominent superomarginal row by a wide lane, containing large papular areas and crossed by stout transverse ossicles uniting the plates of the two rows, but without spines.

The spines generally stand singly on all the dorsal, radial, and superomarginal plates, and all have the same form. They are rather long, terete, regularly tapered, and acute. They are surrounded, near the base, with a dense wreath of minor pedicellariæ of small size.

The inferomarginal plates form a conspicuous row well separated from the upper ones by a wide lane, which contains a row of large papular areas and bears many rather large, erect, lanceolate or subacute major pedicellariæ.

Each plate usually bears two spines, one nearly above the other. The upper one is the larger. It is larger than the superomarginals and dorsals, and is somewhat flattened, often a little expanded distally or sublanceolate, and subacute; the other is distinctly smaller and more acute. Sometimes there is proximally a much smaller third spine below the second, apparently arising from the same plate, but perhaps, in some cases, arising from a rudimentary interactinal ossicle not visible at the surface. The third spine is lacking in specimens a little smaller.

The upper inferomarginal spines bear, at about midheight, a dense cluster of numerous minor pedicellariæ on the upper side. There are also some of the rather large lanceolate major pedicellariæ between their bases. Similar major pedicellariæ occur on and between the adambulacral spines, on the inner margins of the ambulacral furrows, and on the interradial areas.

The adambulacral plates bear each two rather long, slender, flattened, subequal spines, which form two regular rows; the and more flattened or subspatulate. The peroral spines are outer ones are the larger. The adoral spines are longer, larger, 
rather stout and blunt. It appears to be the undetermined starfish described by Nutting (Narrative Bahama Exped., bottom of page 168). This species was dredged by the Bahama Expedition at station 43, off Sand Key, Florida, in 15 fathoms; at station 47, off Key West, in 80 fathoms ; and at station 61, off Key West, in 75 to 80 fathoms. Several specimens were obtained. Perrier recorded it from the Blake stations, off Florida, in 85 and 110 fathoms, one from each place. The type had the radii $6^{\mathrm{mm}}$ and $43^{\mathrm{mm}}$.

\section{Orthasterias contorta (Per.) Verrill.}

Asterias contorta Perrier, Bull. M. C. Z., vol. ix, p. 1, 1881; Mem. Etoiles de Mer, p. 199, 1884.

o. contorta Verrill, op. cit., p. $48,1914 a$.

This species was not figured by Perrier and only imperfectly described. The size was not given. I did not examine his cotypes, in the Museum of Comp. Zoölogy, except in the case of a single lot of small specimens (sta. 155, 88 fathoms). These appeared to me to be the young of $O$. subangulosa.

According to Perrier's description it has no dorsal rows of plates except the carinals, which might be due to immaturity. He also mentions that the submarginal papulæ are large and placed singly. In $O$. subangulosa they are rather small and stand two or three together.

Without farther study of the types it is not possible to say whether they are distinct species.

Perrier recorded this from ten Blake stations, in 11 to 188 fathoms, from Florida reefs to Cariacou and Barbadoes.

\section{Genus Coscinasterias Verrill.}

Cosinasterias Verrill, Trans. Conn. Acad. Sci., i, p. 248, 1867. (Type, C. muricata $\mathrm{V} .=$ (?) C. calamaria (Lam.).)

Stolasterias (pars) Sladen, Voyage Chall., vol. xxx, pp. 563, 583, 1889. (Type, C. tenuispina.) Non Perrier.

Coscinasterias and Polyasterias Perrier, Exped. Trav. et Talisman, p. 108, 1894.

Coscinasterias Verrill, op. cit., pp. 45, 46, 1814a.

Disk small, rays elongated, somewhat angular, usually carinate. Dorsal plates of the rays stout, four-lobed, usually arranged in three or five regular rows, besides the upper marginals, which form regular lateral rows. Interactinal plates form one primary 
(peractinal) row, like the lower marginals, but they may be rudimentary and spineless in half-grown specimens, and only bear spines in large, mature individuals, as in C. tenuispina.

Minor pedicellariæ are abundant. Large forficulate or major pedicellariæ of the usual forms are present, often in considerable numbers, on the dorsal and lateral plates, and smaller ones occur on the marginal areas. Large unguiculate pedicellariæ are lacking. Adambulacral plates are monacanthid or nearly so.

Stolasterias, which was proposed as a subgenus by Sladen in 1889, was nearly identical with Coscinasterias, characterized by me in 1867. He gave no reason for changing the name. It should be regarded as a synonym of the latter and be eliminated. Sladen's type was A. tenuispina, which is a Coscinasterias with the interactinal plates rudimentary and without spines, except in the larger specimens.

As C. tenuispina often divides spontaneously, it belongs to Polyasterias in Perrier's arrangement. This would make the latter strictly synonymous with Sladen's typical Stolasterias.

M. Perrier (1894) correctly retained Coscinasterias for the typical forms, like calamaria, but separated those species that are known to undergo spontaneous fission under the name of Polyasterias = typical Stolasterias Sla., though they do not appear to differ much in structure from the preceding. He retained Stolasterias Sla., in a restricted sense, for those allied to glacialis, although $C$. tenuispina was named by Sladen as the type.

A. glacialis had, long before, been made the type of Marthasterias by Julien.

Coscinasterias tenuispina (Lam.) Ver.

Asterias tenuispina Lamarck, op. cit., 1816, vol. ii, p. 561. Perrier, Revision, op. eit., p. 306, 1875.

Asteracanthion tenuispinus Müll. and Trosch., Syst. Asteriden, p. 16, pl. i, fig. 1, a. b., 1842. Perrier, Pédicellaires, p. 32, pl. i, figs. 3-3c, 1859. Lütken, op. cit., 1859, p. 95.

Asterias (Stolasterias) tenuispina Sladen, pp. 565, 583, 1889. Verrill, The Bermuda Islands, vol. ii, part v, p. 324, in Trans. Conn. Acad. Sci., vol. xii, p. 280, plates xxxiv, fig. 2; xxxiv c, fig. 2, 1907.

Coscinasterias tenuispina Verrill, op. cit., 1814a, p. 45.

Asterias atlantica (pars) Verrill, Transactions Conn. Acad. Sci., vol. i, p. 368, 1868. R. Rathbun, Brazilian Echinoderms, in Trans. Conn. Acad., vol. v, p. 144, 1879 . 


\section{Plate xxvi; figure 2. Plate xxvii; figure 4.}

Disk small. Rays long, rather slender, angular, variable in number. Dorsal and marginal spines are elongated and rather slender. Adambulacral spines slender, one to a plate. Color in life usually pale purplish or violaceous above, yellowish below.

This species is autotomous and therefore is commonly found with the rays unequal and variable in number, from two or three to nine or more, but most frequently with six to eight, three or four being often much shorter than the others. There are usually two or more madreporic plates. Sometimes it is regularly sixrayed or five-rayed. It becomes six to eight inches in diameter at the Bermudas.

The dorsal plates are rather openly united and form a definite median or carinal row and one main dorsolateral row on each side, often with one imperfect second row proximally in large specimens. Each dorsal plate usually has a rather strong, somewhat elongated spine.

The superomarginal row of plates is well marked and forms the lateral margin of the ray. Each plate bears one, or sometimes two, elongated spines, longer than the dorsals. The superomarginals are also strongly developed and have a row of large spines close to the adambulacrals.

The interactinal plates are small and usually without spines, but in very large specimens some of them may bear a small spine.

The adambulacral plates normally bear one long slender spine, but in very large specimens a few bear two spines. In life the color varies. It is usually some light shade of violet or pale purple; yellow below.

This is a common Mediterranean species. It has been reported from Madeira, the Canary Islands, Cape Verde Islands, Brazil, Abrolhos Reefs, Brazil (coll. C. F. Hartt, Yale Mus.), Cuba, the Bermudas, and West Indies. It is the only common starfish at the Bermudas.

It is well adapted, by its habits, to be carried from one country to another, adherent to the bottoms of vessels.

Coscinastertas tenuispina, var. atlantica Verrill.

Asterias atlantica (pars) Verrill, Corals and Echinod. of Brazil, Trans. Conn. Acad. Science, vol, i, p. 368, 1868. 
One of the types of this supposed species was a regularly fiverayed specimen from Cuba. It differs sufficiently from the ordinary form of the species to receive a varietal name, and therefore I propose to designate it as above.

The rays of the type of this form are decidedly angular, relatively shorter and stouter than in the ordinary form. The median radial and two marginal rows of spines and plates are strongly developed, and one dorso-lateral row is less so. The adambulacral spines are monacanthid, as in the typical form. The dorsal and marginal spines are shorter and stouter than in the latter.

The type was from Cuba. I am not prepared to say that the other American forms are fully identical with those of Europe, for I have never been able to study a good series of both in any museum. Valid specific characters may have been overlooked by authors. who unite them.

\section{Coscinasterias linearis (Perrier) Verrill.}

Asterias linearis Perrier, op. cit., p. 2, 1881; Etoiles de Mer, p. 201, pl. iii, fig. 5, 1884.

The type of this species is small and evidently young. It is monacanthid and evidently a Coscinasterias. It may, perhaps, prove to be the young of $C$. tenuispina when a good series can be studied.

The type had the radii $5^{\mathrm{mm}}$ and $50^{\mathrm{mm}}$; ratio, $1: 10$. The rays are five, slender, angular. The dorsal side of the rays has three rows of plates, each of which bears a single elongated spine, thus forming three longitudinal rows of spines. There are three rows of ventral spines. The outer one forms the lateral, larger (inferomarginal) row of spines. Between these and the upper lateral row are large isolated papulæ; on the dorsal side the papulæ are smaller and clustered. There appear to be two rows of interactinal spines proximally. Major pedicellariæ, elongated in form, were found on the disk.

Adambulacral spines are one to a plate. They are straight and not tapered. (Condensed from Perrier's description.) The type was from Blake station 45, in 101 fathoms, off West Florida. 
Genus Leptasterias Verrill.

Leptasterias Verrill, Proc. Boston Soc. Nat. Hist., x, p. 350, 1866. Type, A. mülleri Sars. Sladen, Voy. Chall., xxx, p. 563, 1889. Perrier, Exp. Trav. et Talism., p. 108, 1894. Verrill, op. cit., p. 116, 1814a.

An extensive group of small, more or less diplacanthid starfishes, closely related to typical Asterias, usually with a single row of peractinal plates and spines. Rays five or six. The more typical forms have slender rays and a small disk, with the dorsal ossicles irregularly arranged, or showing several imbricated radial rows, with numerous spines. It differs from typical Asterias in the diminished number and larger size of the dorsal and lateral papulæ, and the small number of actinal plates, of which there is generally only a single row, but more profoundly in having the genital pores on the actinal side, near the mouth, and in the ovaries, which are different in form and produce larger eggs, which have an abbreviated development, passing through no free-swimming larval stages.

The eggs and young are carried in clusters, adhering in front of or around the mouth in all the species studied in the breeding season.

Leptasterias fascicularis (Per.) Verrill. Asterias fascicularis Perrier, op. cit., 1881, p. 1; Mem. Etoiles de Mer, p. 200, pl. iii, fig. 3, 1884.

The type had the radii $9^{\mathrm{mm}}$ and $57^{\mathrm{mm}}$; ratio, $1-6.3$. The five slender rays are slightly contracted proximally. The dorsal and dorso-lateral surfaces of the rays have about seven alternating rows of plates, separated by papular areas smaller than the plates, and containing usually two papulæ, and holding about two or three dermal minor pedicellariæ.

The plates of the median row have a curved row of three or four short, blunt spines; those of the other rows have one or two similar spines; some single spines are also situated on the interpolated ossicles.

The disk is small and covered with spines like those of the rays; between them are some oval major pedicellariæ with curved valves, touching only at tips.

On the under side of the rays there are two rows of plates, near the adambulacrals; each plate bears a single spine and often a dermal minor pedicellaria. 
The adambulacral spines are rather long and slender, two to a plate, divergent, forming two regular rows.

This species seems to be a true Leptasterias, allied to L. compta of New England. Its mode of reproduction and position of genital pores are unknown, and therefore its generic position cannot be positively determined.

The type was from off Guadaloupe, in 309 fathoms.

\section{LEPTASTERIAS HaRti R. Rathbun.}

Leptasterias hartii R. Rathbun, Echinoderms of Brazil, Trans. Conn. Acad. Science, vol. v, p. 145, 1879.

This is a small, six-rayed species. Radii of the type were about $3.2^{\mathrm{mm}}$ and $19^{\mathrm{mm}}$; ratio, $1: 6$.

Rays are well rounded above, tapering regularly to slender tips. The row of median radial plates is distinct; each plate bears a $\mathrm{V}$-shaped row of about five small spines, becoming reduced to two or three distally. Spines on the disk are similar to those on the rays, closely and irregularly arranged.

Above the first lateral radial row there are, on each side, about two longitudinal series of small spines, with many interpolated on the connective ossicles. The rows are not very regular. The first lateral row, probably superomarginals, has two small spines to a plate, distinct to tip of rays; the series above this has, on each plate, transverse, irregular groups of four or five spines, decreasing to a single one distally.

On the under side there are about three rows of plates and spines. The inferomarginal row has usually one spine, seldom two, to a plate.

The two marginal rows are well separated.

The spines of the interactinal plates form oblique series of two or three. They are larger than the adambulacrals, but not much longer, and have compressed clavate tips.

The adambulacral spines are regularly two to a plate, slender and clavate proximally; distal ones tapering; outer ones a little larger.

Major pedicellariæ are large and numerous, variable in size, generally scattered, above and below. They are triangular or ovate in form, with a strongly curved basal piece; about twothirds as broad as long. The larger ones equal or exceed in length the lateral and dorsal spines, and are much stouter. They 
are most numerous between the lateral and ventral spines. The papulæ are mostly isolated.

Taken from a telegraph cable, about 30 miles east of Cape Negro, Brazil, in 62 fathoms.

The description above is condensed from that of Mr. Rathbun.

\section{Leptasterias mexicana (Lütk.) Verrill.}

Asteracanthion mexicanum Lütken, Vidensk. Meddel., p. 94, 1859. Asterias mexicana Verrill, op. cit., p. 344, 1867.

This was described by Lütken from two small specimens from Vera Cruz. They were evidently young. The larger was 1.5 inches in diameter. I am not aware that anyone has obtained additional specimens.

According to Lütken the rays are five; the upper side has about seven rows of short, obtuse, rough spines surrounded by a dense basal wreath of minor pedicellariæ. The papulæ stand two or three together.

The adambulacral plates are one and two to a plate, in pretty regular alternation. They bear pedicellariæ at about midheight. They are slightly flattened, slender, and obtuse. The ventral side has two rows of small spines. (Condensed from Lütken.)

Lütken compared it to $L$. mülleri, the type of Leptasterias. Although it appear's to have the external characteristics of Leptasterias, it may be the young of a larger species of Asterias, like A. forbesi.

There is no reason why $A$. forbesi should not be carried to Vera Cruz adherent to the bottoms of vessels from our southern ports, even if it does not habitually live on the Mexican coast. Many other creatures are thus carried to distant places and no doubt, in many cases, become naturalized in new homes by this means. I have not seen A. forbesi from the Gulf of Mexico, but should expect to find it on the coast of West Florida and Alabama.

Genus Stephanasterias Verrill, 1871. Type, S. albula.

Stephanasterias Verrill, Bull. Essex Inst., iii, p. 5, 1871; Expl. of Casco Bay, Proc. Am. Assoc. Adv. Sci. for 1873, pp. 356, 359, 364, 1874;

Check List Invert., 1879; Expl. Albatross, 1883, p. 540, 1885.

Nanaster Perrier, Exp. Trav. et Talism., pp. 129, 131, 133, 1894; Camp. Scientif. ]'Hirondelle, p. 27, 1896. (Type, S. albula.)

Stichaster (pars) Verrill, 1866, ․ 351. Perrier, p. 347, 1875. Sladen, p. $432,1889$. 
Stephanasterias Verrill, Revision Genera and Species of Starfishes, p. 222, 1899; North Pacific Starfishes, op. cit., p. 146, 1814a.

Small autotomous starfishes, commonly fould with five to nine unequal rays, due to incomplete replacement and regulation of rays after division. Two or three longer rays, and three or four shorter ones are common forms. When fully mature, often regularly six-rayed.

The whole surface is thickly covered with minute thorny spinules, placed in clusters on the plates, and longer on the under side and margin.

The median-radial and marginal rows of plates are usually distinct, with wide plates, closely imbricated radially. The several dorsolateral rows have the plates small, short, and relatively wide, irregularly arranged, but with longitudinal rows of papular pores between them.

The inferomarginal and interactinal plates form regular, close, longitudinal rows.

The adambulacral spines are slender, two to a plate, or alternately one and two. Papulæ are isolated or in small groups. Both kinds of pedicellariæ are present.

Perrier changed the name of this genus to Nanaster, because he erroneously assumed that Stephanasterias had been preoccupied by Stephanaster Ayres. The two names are distinct and differently derived.

\section{Stephanasterias gracilis (Per.) Verrill.}

Asterias gracilis Perrier, op. cit., p. 4, 1881; Nouv. Arch. du Mus., vi, p. 204, 1884.

Stephanasterias gracilis Verrill, Trans. Conn. Acad. Sci., vol. x, p. 223, 1879 ; Starfishes N. Pacific, p. 146, 1914a.

\section{Plate ix; figures 2-2c.}

Disk small; rays slender, variable in number, commonly six. The species is autotomous, and the rays are often unequal.

The dorsal surface is closely covered with numerous nearly uniform minute, slender, subdiaphanous spinules, several on each plate. The marginal spines are larger, flattened and enlarged distally, mostiy with a blunt and thorny tip, and more or less hyaline.

The adambulacral spines are two to a plate, shorter and nuch 
more slender than the marginals, slightly clavate, subhyaline; oral and adoral spines similar.

This closely resembles $S$. albula, of the northern coast and arctic regions. It seems less variable in number of rays and is perhaps less often divided by autotomy. Its marginal spines are longer, more expanded and flatter.

I have examined several of the types of this species in the Museum of Comp. Zoölogy, from the Blake Expedition, described by Perrier.

It was taken by the Blake at nine stations in 56 to 183 fathoms, among the Lesser Antilles, and at two stations in the Gulf of Mexico, off West Florida, in 95 and 101 fathoms. The Albatross also took it at many stations.

It was obtained by the Bahama Expedition, off Havana, in 110 and 200 fathoms (stations 4 and 13), and off East Florida, in 110 fathoms (station 64,6 specimens).

\section{Stephanasterias hebes Verrill, sp. nov.}

Plate ix; figure 3.

General appearance and size much as in $S$. albula, but stouter with less numerous and less delicate spines.

The adambulacral spines form two perfectly regular divergent rows. They are relatively short and not very slender, terete or slightly clavate and blunt. The ambulacral furrow is relatively very wide and the sucker feet large. Owing to the shortness of the spines and width of the groove, the adambulacral spines cover only a small part of its margins.

The interactinal and inferomarginal spines are much larger and stouter than the adambulacrals and much more so that in S. albula. They are about twice longer and more than twice thicker than the adambulacrals adjacent. They are clavate, with rounded or obtuse tips, not so thorny as in S. albula, nor so translucent. The dorsal spines are similar, but shorter, arranged in close clusters on the plates.

Taken by the Albatross at station 2766, in - fathoms. (No. 18,426, Nat. Mus.)

This is very much stouter than $S$. gracilis, with much larger and more clavate spines. 


\section{Family ZoROASTERID E Sladen.}

Zoroasteridae Sladen, op. cit., pp. xxxvi, 416, 1889. Perrier, Exped. Trav. et Talisman, p. 112, 1894. Ludwig, op. cit., 1905, p. 159.

Disk small; rays long and slender, angular or rounded.

The disk is covered largely by the ten enlarged basal radials and interradials, and the large central plate.

A row of large overlapping carinal plates stiffens the rays, each usually bearing a spine. Marginal plates scarcely differentiated from the dorso-laterals and interactinals.

All these form close, regular, imbricated, longitudinal rows, often six to eight proximally. They are also imbricated in transverse rows.

All the plates are granulated or finely spinulose and the lateral and interactinal rows usually bear, also, a single elongated spine, and usually a dermal major pedicellaria. Papular pores are single and placed between all the rows of plates.

Adambulacral plates are alternately unlike. The larger are compressed, carinate, and project far into the groove. They bear a divergent row of several spines transverse to the groove, and have one or two small spines in the groove. The alternate small plates do not project into the groove, are not carinate, and bear fewer spines. Spines of both kinds of plates may bear large major pedicellariæ.

Minor or crossed pedicellariæ appear to be lacking. Suckerfeet are in four rows proximally, becoming reduced to two rows distally. Their suckers are small.

This is essentially a deep-sea family. Only a few species have occurred in less than 150 fathoms.

\section{Genus Zoronster Thomson.}

Zoroaster W. Thomson, Depths of the Sea, p. 154, 1873. Sladen, op. cit., p. 416, 1889. Perrier, op. cit., 1894, p. 115. Fisher, op. cit., 1911b, p.

The central plate of the disk has few smaller plates around it. The basal radials are prominent, but not much larger than the next radials and of the same character. The basal interradials are smaller and flatter, without a central spine. The central plate and basal and median radials have a central short articulated spine. The whole surface is covered with a rather thick dermis and with small articulated spinules, attached to basal papillæ. 
In addition to these the lateral and interactinal plates have one slender, articulated spine.

The dorso-lateral row of plates next the carinal row is differentiated, the plates being larger than the others and similar to the carinals. The rest of the lateral and interactinal plates are all similar, forming six to eight regular rows, imbricated both longitudinally and transversely, leaving only small papular pores between them. Marginals are not much different from the rest.

Adambulacral plates of two sorts are very unlike. The larger carry four to six divergent slender spines, along the thin carinate edge; the larger one at the margin of the groove may bear one or several major pedicellariæ, often large; other spines may bear smaller ones. The much smaller alternate plates are not carinate and bear usually two slender outer spines and a small one in the furrow. Major pedicellariæ are scattered on the back and sides.

\section{Zoroaster ackleyi Perrier.}

Zoroaster ackleyi Perrier, Comptes rendus, 1880, p. 436; op. eit., p. 6, 1881; Etoiles de Mer, p. 197, pl. iii, fig. 1, 1884; Exped. Trav. et Talisman, p. 117, 1894. A. Agassiz, Three Cruises of the Blake, vol. ii, p. 105, fig. 382.

The largest specimen examined by me has the radii $10^{\mathrm{mm}}$ and $105^{\mathrm{mm}}$; ratio, $1: 10.5$; diameter of rays at base $10^{\mathrm{mm}}$; height $11^{\mathrm{mm}}$.

The small disk is convex or a little swollen. The long slender rays are well rounded at the base, but become somewhat carinate on the attenuated distal half.

The disk is occupied largely by the ten basal radial and interradial plates, and a large prominent central plate, with a central mamilla supporting a short obtuse spine.

The dorsal radials are larger and more elevated than the interradials and have a central boss, which bears a short obtuse spine. They are rounded with small notches or emarginations around the margin, where there are isolated papular pores. Similar pores surround the central plate.

The basal interradials are flatter and more angular and have no central spine. They are in contact with the radials laterally. One of them is partly covered by the madreporic plate, which is rather large and convex, with radiating gyri. 
The central plate of the disk is surrounded by several small plates, and by papular pores.

All the plates of the disk and dorsal side of the rays are thickly covered with minute rough spinules that leave little round scars when rubbed off.

Pedicellariæ of the forficulate kind, much larger than the spinules, are scattered over the whole surface, usually but one to a plate. When closed they are ovate-lanceolate, and somewhat compressed, subacute.

The median radial row of plates is conspicuous. They are rather large, convex, with a small central boss, carrying a small short, thick spine, which is somewhat enlarged or obtuse at tip; the distal ones are smaller and acorn-shaped. They are easily detached and are often rubbed off. They are often absent from the distal part of the rays. These radial plates are shieldshaped, with rounded sides and overlap each other serially.

The sides and lower surfaces of the rays are proximally made up of seven to nine regular rows of small shield-shaped plates, all much alike, except the first row, so that it is not easy to distinguish the marginal rows. The row next the median radials has larger, angular plates, similar to the median, though smaller. The others are imbricated transversely, in regular vertical rows, decreasing in size downward, and overlapping with their angular lower end, like slates on a roof.

In five or six lower rows each plate bears on a boss, a long, slender, very acute spine, decreasing upward in length, where they nearly intergrade with the spinules of the upper plates. These spines are also accompanied by small, acute spinules, and each plate usually has a rather large lanceolate or acute-ovate pedicellaria. Distally a similar spine appears also on the row next to the carinal row.

The adambulacral plates are alternately large and small. The larger ones are carinated and project far into the groove and bear, on the curved edge, five or six slender acute spines, of which two or three are within the groove, one far within, and the others form a divergent row, transverse to the furrow, the middle or marginal ones longest. Many of these spines, both within and outside the furrow, bear a single large, forficulate or major pedicellaria, some of them much thicker and about as long 
as the spine, and much larger than those of the dorsal surface. Some spines have also two or more smaller ones. The larger ones, on the marginal spine, are compressed, long ovate, with acuminate or contracted tips; the smaller ones are acute-ovate, like the dorsal ones. The largest occur on the outer dorsal spines.

The peroral and adoral spines are considerably elongated and acute. The oral area is deeply concave, so as to conceal most of the spines. The smaller alternate adambulacral plates are not carinate and do not project into the grooves. They usually bear one very small inner spine and two longer very unequal outer ones.

The ambulacral sucker-feet are large. Proximally they form four rows; farther out they are in two zigzag rows on each side; toward the end of the rays, they are reduced to two nearly straight rows.

This was taken by the Blake, at station 134, off Santa Cruz, in 248 fathoms, 10 specimens; and at station 157, off Montserrat, in 120 fathoms, one specimen.

The specimens studied by me were mostly taken by the Albatross. The larger, described above, was from station 2396, off Pensacola, Fla., in 335 fathoms, gray mud, bottom temperature $41.80^{\circ}$ F. (No. 18,450 , Nat. Mus.) The other was from station 2394, also off Pensacola, in 525 fathoms, light gray mud (No. 10,422). It was also taken at several other localities.

\section{Family Pedicellasteridez Perrier.}

Pedicellasteride Perrier, Etoiles de Mer., pp. 167, 194, 1884; Exped. Trav. et Talism., p. 92, 1894. Sladen, op. cit., p. 556, 1889. Verrill, op. cit., p. 202, 1914a.

Pedicellasteride (pars) Perrier, op. cit., 1885, p. 15.

Disk small, rays usually five or six, sometimes ten to twelve or more, as in Coronaster. Dorsal skeleton usually reticulated, or with few rows of plates.

Ambulacral feet are in two rows, at least distally. The jaws are formed by modified adambulacral plates. Pedicellariæ are of two kinds, much like those of Asteriidæ. 
Genus Coronaster Perrier.

Coronaster Perrier, Ann. Sei. Nat. Zoöl., vol. xix, No. 8, pp. 5, 9, 1885; Exped. Trav. et Talism., p. 92, 1894. (Type, C. parfaiti.) Sladen, op. eit., pp. xxxix, 592, 1889.

Delicate starfishes with a small disk and numerous slender rays, covered with long, slender spines in radial rows. The dorsal skeleton is weak, made up of the rows of median and superomarginal plates, connected together by slender transverse ossicles. Each plate of the longitudinal rows usually bears one slender spine.

Both rows of marginal plates well developed and spiniferous. No interactinal plates. Adambulacrals diplacanthid. Large, felipedal, dermal major pedicellariæ occur above and below. Minor pedicellariæ form large circumspinal wreaths, borne on contractile sheaths. Tube-feet are relatively large, in two rows, not erowded. A pair of rather large peroral spines on the margins of the oblong jaws, with groups of oral marginal pedicellarix.

Coronaster Briareus Verrill, $1914 a$, p. 49.

Asterias briareus Verrill, Brief Cont. to Zoöl., No. 50, Amer. Journal Sci., vol. xxiii, p. 220, 1882; Notice of Rem. Maine Fauna, in Annual Rep. Com'r. of Fish and Fisheries for 1882, p. 659, 1884, ditto for 1883, p. 540; Amer. Jour. Science, ser. 3, vol. xlix, p. 209, 1895. Starfish "near Asterias volsellata," Nutting, Narrative Bahama Exped., p. 168, fig. 3, 1895.

\section{Plate $\mathrm{i}$; figures 1, 2. Plate ix, figures 4-4c.}

Disk small,rays slender, elongated. Rays variable in number, ten to twelve in the larger specimens, one of the larger has the radii $8^{\mathrm{mm}}$ and $76^{\mathrm{mm}}$; ratio $1: 9.5$.

The dorsal skeleton is openly reticulated. There is a marked medial radial carina, with larger plates and longer spines. The marginal plates also form ridges. These five rows of plates are connected by slender transverse ossicles, leaving large rectangular papular areas, with numerous papulæ in clusters.

The dorsal and marginal spines are long, slender, acute, not very near together. A few arise, also, from the transverse ossicles.

The spines are all much alike in form and size. They bear large dense wreaths of small minor pedicellarix, usually on a 
sheath which may be contracted to near the base or extended to near the tip in preserved specimens.

Solitary felipedal or unguiculate major pedicellariæ of large size and remarkable in form are scattered on the dermis, above and below; others are on the inner furrow margins. They are hand-shaped, with eurved, acute terminal denticles, interlocking like fingers or claws. The valves are wider distally and there are generally about five or six interlocking denticles.

The adambulacral spines are two to each plate, slender, elongated. There are no interactinal plates nor spines; the inferomarginals join closely to the adambulacrals.

It was taken by the Bahama Expedition at Station 61, off Key West, in 75 to 80 fathoms, and at Station 64, in 110 fathoms, off American Shoal, Florida.

It was dredged by the U. S. Fish Commission, at several stations in 31 to 373 fathoms, between N. lat. $37^{\circ} 18^{\prime} 11^{\prime \prime}$ and $36^{\circ} 41^{\prime} 05^{\prime \prime}$.

This is the species described by Professor Nutting, as the most beautiful starfish obtained. See Narrative of Bahama Expedition, p. 168, and figure on opposite plate.

\section{Genus Pedicellaster Sar's.}

Pedicellaster Sars, Oversigt Norges Ech., p. 77, 1861. Perrier, op. cit., 1884, p. 194; Exped. Trav. et Talism., p. 99, 1894. Sladen, op. cit., p. 557, 1889. Verrill, op. cit., p. 202, 1914a.

Delicate starfishes with a small disk and usually five or six slender rays, sometimes more. Dorsal plates form a reticulation. Ambulacral feet in two rows. Ambulacral groove relatively wide and open. Dorsal and marginal plates are covered with small spinules.

Pedicellariæ of both kinds are formed on most, if not all, species when adult.

\section{Pedicellaster pourtalesi Perrier.}

Pedicellaster pourtalesi Perrier, Bull. Mus. Comp. Zoöl., vol. ix. p. 7, 1881; Etoiles de Mer, p. 194, pl, iii, fig. 4.

Rays very slender, fragile at base, elongated, terete, obtuse. The type had the radii $4^{\mathrm{mm}}$ and $21^{\mathrm{mm}}$; ratio, about $1: 5$.

Dorsal plates are delicate mostly in three rows, a carinal and 
one dorsolateral on each side, united transversely by small ossicles. Each principal plate bears a single small spine, marginal plates and spines are similar.

The adambulacral plates are relatively large; each bears two or three small, slender spines in a transverse row.

The madreporic plate is small, with few gyri. Minor pedicellarix are dermal, scattered between the dorsal spines.

Recorded by Perrier from four Blake stations, among the Lesser Antilles, in 127 to 250 fathoms. It was also taken by the Albatross in the same region.

\section{Order Spinulosa Perrier.}

Stellerida Spinulosæe Perrier, Nouv. Arch. Mus. Hist. Nat., vi, p. 154, 1884. Spinulosa Perrier, Exped. Trav. et Talism., pp. 27, 138, 1894.

Phanerozonia and Cryptozonia (pars) Sladen, Voy. Chall., xxx, p. zxiii, 1889. Spinulosa Fisher, op. cit., 1911b, p. 251. (Table of known families.) Verrill, op. cit., pp. 24, 304, 1914a.

This order, established by Perrier, includes cryptozonate (rarely subphanerozonate) starfishes, which usually have !but two rows of ambulacral feet (four in Diplopteraster). The ambulacral plates are not crowded. The dorsal plates, generally reticulated or imbricated, spinulose, granulose or naked, often form pseudopaxillæ or parapaxillæ, but they rarely, if ever, form true paxillæ. The dorsal plates are sometimes isolated, rudimentary, or absent in deep-sea genera. The pedicellariæ are commonly lacking; when present they are neither forcipulate nor forficulate. They may be pincer-like, with two or more simple valves, and are always dermal.

Perhaps the structure of the pedicellariæ is the most positive character for separating certain genera of this group from some of the aberrant Forcipulosa.

The marginal plates are nearly always small and sometimes indistinct; the lower ones are usually the larger; they never form a thick rigid margin; the margin may be acute or rounded. Papulæ may occur both on the dorsal and on the actinal surfaces, but they are restricted to the dorsal surface in most families. The odontophores are adambulacral and of various forms. The ambulacral grooves are usually narrow. The ambulacral feet always have a terminal sucker. The ambulacral ampullæ may be single (Echinasteridæ) or double. 
A number of the genera do not have free-swimming larvæ,* but are known to carry their eggs and larvæ attached about the mouth, or else in a marsupial pouch (gonocodium) until they become true starfishes, large enough to care for themselves. This habit is usually associated with the lack of pedicellariæ. It is conducive to the formation of local varieties. The order may be naturally divided into two suborders:

Suborder I - Avelata Ver., op. cit., 1913; 1914a, p. 204.*

This includes the more typical forms in which there is no dor'sal, tent-like marsupial chamber for the protection of the eggs and young. The spines are either all free, or partially or wholly webbed together into groups, as in Solasterida, in which the groups of adambulacral spines form transverse combs completely webbed together, and the dorsal spinules are partially so.

It includes the following families represented in this collection :

Echinasterida; Solasterida; Korethrasteride, deep sea; Asterinida; Poraniida. Also the following extralimital families, besides other smaller groups: Acanthasteride; Mithrodide; $P y$ thonasterida, deep sea; Myxasterida, deep sea.

\section{II - Suborder Velata Perrier (as an order).}

This group includes only the family Pterasterida. It is remarkable for having most of the spines webbed together in clusters and for the remarkable development of a superdorsal membrane, more or less completely uniting the paxilla together, and usually forming a dorsal marsupial pouch or gonocodium in which the eggs and young are carried.

Subordel Avelata Verrill (See above).

Family Echinasterid E Verrill (restricted).

Echinasteride Verrill (pars), Trans. Conn. Acad. Sci., i, p. 343, 1867. Perrier (pars), Revis. Stell., Arel..'Zoöl., iv, pp. 299, 358, 1875.

Echinasterina Viguier, Arch. Zoöl. Exper. et Gen., vii, p. 123, 1878 (structure.)

Echinasterides Sladen (pars), Voy. Chall., xxx, p. 535, 1889. Bell, Catal. Echinod., pp. 23, 95, 1890. Perrier, Etoiles de Mer, Nouv. Arch. Mus. Nat. Hist., vi, p. 164, 1884; Exp. Trav. et Talism., pp. 28, 141,.

* This is the case with the genera Henricia, Pteraster, Hymenaster, and others.

* There once misspelled as Alvelata. 
1894. Ludwig, Fauna Arctica, i, p. 472, 1900. Fisher, op. cit., 1911b, p. 258, analytical table known genera, p. 259. Verrill, op. cit., p. 205, $1814 a$.

Dorsal skeleton usually formed of small, sometimes overlapping, reticulated or areolated plates; sometimes they form longitudinal radial rows. Median dorsal row is often indistinct. Upper marginals small, often not specialized. Inferomarginals usually distinct. One or more interactinal rows are usually present. Dorsal and marginal spines may be large and isolated or minute and clustered, but not truly paxilliform. They are often covered with a distinct, thick, dermal membrane, which may contain calcareous granules.

The ambulacral ampullæ are usually single, one to each tubefoot.

Ambulacral grooves narrow. Adambulacral spines small, two or several to a plate, usually in a transverse group or a single transverse row. No pedicellariæ are known.

The most prominent genera are Echinaster and Henricia, both of which occur in the West Indies.

Genus Echinaster Müller and Troschel, emended.

Echinaster (pars) Müller and Troschel, Monatsber., Berlin. Wis. Akad., April, 1840, p. 102 ; Wieg. Arch., 1840 (non Gray); Syst. Aster., p. 22, 1842 (pars).

Othilia Gray, Ann. Mag. Nat. Hist., vi, p. 281, Dec., 1840; Synopsis Starfishes, p. 12, 1866. Fisher, $1911 b$, p. 260.

Echinaster Perrier, Revis. Stell. du Mus., Arch. Zoöl. Exper., iv, p. 364, 1875. A. Agassiz, North Amer. Starfishes, p. 97, pl, x, 1877 (structure of skeleton.) Viguier, Squelette Stell., Arch. Zoöl. Exper., vii, p. 123, pl. vii, figs. 1-7, 1878 (structure of skeleton.) Sladen, Voy. Chall., Zoöl., xxx, p. 553, 1889. Perrier, Exp. Trav. et Talism., p. 146, 1894. Verrill, op. eit., p. 206, $1914 a$.

Stellate, usually with the disk rather small. Rays normally five, of moderate length, rounded. Larger dorsal and marginal plates strong, lobate, convex in the middle, and having a central mammilla and pit for the attachment of the usually solitary spine. The larger ossicles are united into reticulations by small, rounded, connective ossicles, leaving large papular areas; solitary papulæ may occur in the marginal and actinal regions.

The whole surface is covered in life with a rather thick, soft integument, containing small granules on the spines. Dorsal 
spines are conical, acute, mostly isolated, sometimes in small groups.

Upper and lower marginal plates are not very distinet, with spines like the dorsals. Adambulacral spines form a small oblique or transverse row of two to four; the inner ones are smaller, inserted in the groove, just above the margin.

The genus Othilia Gray, December, 1840, appears to be a synonym of Echinaster Müller and Troschel, April, 1840. The type of the latter was $E$. spinosus ${ }^{8}=A$. echinophora Lam., both by virtual tautology and by designation. (See foot-note in Müller and Troschel, Syst. Ast., p. 22, 1842.) Echinaster of Gray, 1866, is Acanthaster of later writers.

This genus is found in all tropical and subtropical seas, chiefly in shallow water.

\section{ECHINASTER sentus (Say) Lütken.}

Asterias sentus Say, Journ. Philad. Acad., v, p. 143, 1825.

Othilia aculeata Gray, Annals Nat. Hist., vi, p. 281, 1840; Gray, Synopsis Starfish, p. 12, 1866.

Echinaster spinosus (pars) Müller and Trosch., Syst. Ast., p. 22, 1842. Verrill, Notes on Radiata, p. 343, 1867. Ives, Proc. Acad. Nat. Sci. Philad., for 1890, p. 325. Clark, Echinoids and Asteroids of Jamaica, p. 6, 1898.

Othilia spinosa Agassiz, Bull. Mus. Comp. Zoöl., p. 308, 1869.

Echinaster sentus (Verrill, MSS., 1866). Lütken, Vid. Meddel., pp. 60, [284], 1871; 9 Perrier, Arch. Zoöl. Exper., iv, p. 366, 1875; A. Agassiz. North American Starfishes, p. 97, pl. $x$, figs. 1-6, 1877 (figs. of living and structure.) R. Rathbun, Echinoderms of Brazil, p. 147, 1879.

Plate xxix ; figure 2. Young.

The two marginal rows of plates are pretty regular but not much differentiated from the others in size or form. The upper row usually has only one stout conical spine, with a mammiform base, on each plate. It turns upward proximally, reaching the dorsal side, and leaving a wide interradial intermarginal area, in which there are a number of spineless plates, and usually one short intermarginal row of plates bearing one spine each in a typical specimen from Florida.

8 The name spinosus (Retz.) is not tenable for any species of the genus for Asterias spinosa $\mathrm{R}$. was antedated by A. spinosa Pennant, 1777.

9 Lütken here refers to Verrill (correspondence) and to his determination in 1866 (op. cit., p. 348), of sentus. 
The intermarginal plates are like the upper ones, but extend regularly to near the small adoral area. Some of them sometimes bear two, or even three, conical spines, close together, but ordinarily only one. The peractinal plates form a single row of small, oblong, transverse connective ossicles between the inferomarginals and the adambulacrals. Between them are large papular pores, either isolated or in small groups; many of these ossicles are without spines, but some of them usually have a small conical spine, near the outer adambulacrals.

The adambulacral spines are small and subacute, in somewhat oblique transverse series of three. They are much smaller and more numerous than the adjacent spines, about four of their plates corresponding to one marginal plate. The inner furrowspine is much the smaller; the next is nearly as large as the outer one. These last are webbed together basally and thus form a continuous regular border to the furrow. Most of the dorsal spines can be referred to five irregular rows, above the superomarginals. These are one pretty distinct median radial row, and two less distinct dorso-lateral rows on each side. There are also some irregular interpolated spines on the connective ossicles. Many of the larger plates bear two and some three clustered spines.

The papular areas are large and the papulæ are very numerous, not only on the dorsal side, but also between the marginal rows, and are present also next to the adambulacrals, where they beconie less numerous.

The madreporic plate is raised, flat, wart-like, covered with rough projections, like stout spinules.

The Young. Plate xxix; figure 2.

A young specimen, apparently of this species, was taken by the expedition in shallow water on the Great Bahama Bank. Its radii are $7^{\mathrm{mm}}$ and $26^{\mathrm{mm}}$. It has the two rows of marginal spines well developed and pretty regular. There are about eight or nine in the upper series and about twelve in the lower. They are relatively large, conical, acute.

The dorsal spines are similar in size and form. They form, on some of the rays, too pretty definite dorso-lateral rows of five or six, with a few in the median row. In other cases the median 
row has five or six spines and the doso-lateral ones fewer. The papular pores are small and numerous dorsally; few and mostly isolated below the inferomarginal spines. A row of small interactinal plates separates the inferomarginal plates from the adambulacrals and some of these bear rudimentary spines, and many have small solitary papulæ between them.

The adambulacral plates have three small spines in an oblique row; the inner one is very small and deep in the furrow; the outer ones are webbed together longitudinally. Color, when dry, pale yellowish brown. The madreporite is small, round, rough with minute spinules.

\section{TERATOLOGY.}

A regular four-rayed specimen was obtained by the Bahama Expedition at the Great Bahama Bank, in shallow water, May $17,1893$.

The radii are $13^{\mathrm{mm}}$ and $53^{\mathrm{mm}}$; ratio, $1: 4.1$. The dorsal spines are rather numerous, subequal, of moderate size and acute. They do not form definite or obvious rows, but appear as if in about six or seven zigzag and irregular rows proximally. They are not crowded.

Papular areas, between them, are large, with many rather large pores; these areas form about six irregular rows. Additional ones exist between the rows of marginal spines and scattered papulx occur between the inferomarginals and the adambulacrals, and between the interactinals.

The rows of superomarginal spines are not clearly distinct from the dorsals, being of the same size and form and the rows are irregular. The inferomarginal row is more regular, but the spines are of the same size. This row is near the adambulacral plates and about four of the adambulacral plates correspond to each of these spines in the amount of space occupied. There are about twenty to twenty-four of these spines in each row. Proximally there is a short irregular intermarginal row, and also a row of small interactinals, the latter mostly spineless.

The adambulacral plates mostly bear three partially webbed spines. Two on the outer surface are subequal, one nearly 
above the other; the other is much smaller and deeper in the groove; distally there is often another smaller furrow-spine still deeper in the groove. The madreporite is round, elevated, wartlike, and covered with small rough spinnles. The color of the dry specimens is yellowish brown, to dark purplish brown.

Mr. A. Agassiz (op. cit., 1877, pl. x) gave excellent figures of this species from living specimens as well as many structural details of the skeletal parts.

It is the common shallow water species found on our coast, from North Carolina to Florida. In the number and size of the spines and the number of the rows it exceeds $E$. echinophora, but has many less than $E$. spinulosa.

Most of the earlier writers, including Lamarck, Müller and Troschel, and many others combined this with $\boldsymbol{E}$. echinophora, under the specific name "spinosus," a name that was often attributed to Retzius, 1805 (as Asterias spinosa), which was antedated, however, by $A$. spinosa Pennant. It is doubtful, as shown by Lütken, whether the brief diagnosis of Retzius refers to any Echinaster. In any case it was preoccupied and cannot be used for any species of this genus.

The Asterias spinosa of Say, 1825, was primarily the common Asterias forbesi of our coast, but also included $A$. vulgaris, for he had specimens from the coast of Maine.

This determination, and also the fact that Say's A. sentus, was an Echinaster like spinosus of authors, was published by me in 1866. (Proc. Boston Soc. Nat. Hist., vol. x, p. 348) and was earlier communicated to Lütken. I did not publish the combined names at that time.

This species occur's in shallow water on the southern coasts of the United States, from North Carolina to the Florida Reefs, and to Yucatan. It is also common in the West Indies, from the Bahamas to St. Thomas. I have seen it from Cuba, Bahamas, and Hayti. Yucatan (Ives), St. Thomas (Luitken), Bahia and Pernambuco, Brazil (R. Rathbun), Jamaica (Clark).

The Bahama Expedition took specimens on the Great Bahama Bank, including one four-rayed specimen, described above. 


\section{ECHINASTER SPINULOSUS Verrill.}

Echinaster spinulosus Verrill, Proc. Boston Soc. Nat. History, vol. xii, p. 386, 1869. Lütken, op. cit., p. 285 [61], 1871. Ives, op. cit., p. 326, 1890 .

\section{Plate iv; figures 1, 2.}

This species is characterized by having long, slender, terete, tapered rays, covered with numerous small, conical, subacute or often blunt spinules, in many more or less evident rows, and often standing two or three on a plate. The number in each row may be forty or more.

The number of rows, exclusive of inferomarginals, may be from fifteen to twenty-one in the larger examples. A mediumsized specimen (type) has the radii $12^{\mathrm{mm}}$ and $72^{\mathrm{mm}}$; ratio, $1: 6$. The largest specimens have the radii about $14^{\mathrm{mm}}$ and $80^{\mathrm{mm}}$.

A typical specimen of medium size from West Florida has these characters; the two rows of marginal plates can readily be distinguished in this and in most other dried specimens, not only by their larger size and more rounded form, but also by a finely granulated and well defined patch on the convex part of each plate and mostly below the single spine, but often including most of the surface of the plate. Over this granular surface the investing dermal membrane is so thin that the granules can usually be seen without preparation, and sometimes they appear as if naked. They are not found on the intermarginal and peractinal plates.

The two rows of marginals are pretty regular and can be traced to the tips of the arms, each bearing one small conical spine. On the distal third of the ray the two rows are contiguous; on the proximal part they are separated by two or three short, irregular rows of intermarginals, each bearing a conical spine. In the interradial area additional spineless plates are interpolated, broadening the area, for here the upper marginal row turns upward to the dorsal side.

Many papular pores are found between the marginals and intermarginals, but none below the inferomarginals in most specimens.

Granulated patches also occur on the plates of the principal dorsal rows.

The interactinal or peractinal plates and spines form a pretty regular row, extending nearly to the tips of the rays, 
where they become very small. Most of them bear one small conical spine, close to the outer adambulacral. The outlines and sutures of these plates are usually concealed by dermis; sometimes proximally, a number of them are spineless and visible, when they appear as narrow, flat, oblong, transverse ossicles, extending between the inferomarginal and adambulacral plates. The adambulacral plates have two small furrow-spines, one above the other. The most interior one is the smaller; on the outer margin, and not quite in line with the others, there is a somewhat larger and stouter but small, conical spine. Those on consecutive plates are webbed together for about half their height and also webbed to the upper one of the furrow-series, forming a continuous row.

The madreporic plate is prominent, flattish, wart-like, covered with thin, rough, irregular ridges and points.

Alcoholic and well dried specimens of this species are usually purplish brown, but many, when dried, become yellowish brown. In life it is reddish brown.

This species is abundant on the west coast of Florida, at Tampa Bay, Egmont Key, and many other localities.

In the Yale Museum, besides the types from Egmont Key, there are specimens received from the U. S. Nat. Mus. from the following places: Pine Key, Cedar Key, Goodland Point, and Marco, W. Florida; Gulf of Mexico, S. of Alabama (stations 2370, 2373, 2387, steamer Albatross), in 23 to 32 fathoms. I have seen no West Indian specimens nor any from East Florida.

This is more nearly allied to $E$. braziliensis than to either of the other species.

It has many more rows of spines than $E$. sentus, and many more spines in each row, while the spines are also much smaller and more slender. The rays are also longer and more slender.

Echinaster braziliensis M. and Tr.

Echinaster braziliensis M. and Troseh. (pars), Syst. Aster., p. 22 (not the figure, pl. i, fig. 4). Lïtken, op. cit., p. 9 [67], 1859; p. 284 [60], 1871. Verrill, Notes on Radiata, pp. 343, 368, 1868. Perrier, Archiv. Zoöl. Erp., vol. iv, p. 367, 1875. R. Rathbun, Trans. Conn. Acad Sci., vol. v, p. 148, 1879. Ludwig, Mem. Cour. Acad. Roy. Belg., xliv, p. 7, 1882. Ives Proc. Acad. Nat. Sci. Philad., for 1890, pp. 324, 326, pl. viii, figs. 16-18, 1890.

(?) Othilia braziliensis A. Agassiz, Bull. Mus. Comp. Zoöl., vol. i, p. 308, 1869 (Florida, shore to six fathoms.) 
Plate xxvi; figure 1.

The ratios of the radii are about $1: 5$. The rays are terete and rather slender. The spines are numerous, small, acute-conical, not much larger than the outer adambulacrals. On the rays they form about nine to eleven rows in the adult, with thirty or forty in the median row, in specimens $112^{\mathrm{mm}}$ in diameter. The adambulacral plates have three spines.

The spines are larger and fewer than in $E$. spinulosus, but much more numerous and smaller than in $E$. sentus.

Color in life rust-red, paler below. (Ives.)

The figure of a portion of a ray given by Müller and Troschel does not agree with their description. It probably represents E. sentus.

This Brazilian species has been recorded from shallow water on the Florida coast by Mr. A. Agassiz; from Jamaica, by Lütken and Verrill; and from Yucatan by Ives. On the Brazilian coast it has been recorded from Pernambuco (Rathbun) to Rio de Janeiro (Perrier). The Yale Museum has it from Bahia and Pernambuco (coll. C. F. Hartt, Nos. 5206, 5208, 4559). Also a specimen, perhaps of this species, from Cuba (No. 263). Mr. Rathbun doubts the Rio de Janeiro record. Some of the other records are also doubtful, owing to confusion with allied species. That of Florida is doubtful. I have seen no specimens from Florida nor from the Bahamas.

Echinaster echinophorus (Lam.) Perrier.

Asterias spinosa (pars ?) Retzius, Dissert. sist. spec. cog. Asteriarum, p. 18, 1805 (non Asterias spinosa Pennant 1777).

Asterias echinophora Lam., Anim. sans vert., ed. I, vol. ii, p. 560, 1816.

Othilia spinosa Gray, Ann. and Mag. Nat. Hist., vi, p. 281, Dee., 1840; Synopsis Starfishes, p. 12, 1866.

Echinaster spinus Müll. and Trosch. (pars), Syst. Ast., p. 22, 1842; Lütken, Vidensk. Meddel., p. 90, 1859. Perrier, Pédicell., p. 57, 1869. Echinaster (Othilia) crassipina Verrill, Trans. Conn. Acad., i, p. 368, pl. iv, fig. $7,1868$.

Echinaster crassispinus Lütken, op. cit., p. 283 [61], 1871. Ives, op. eit., 1890 , p. 326.

Echinaster echinophorus Perrier, Arch. Zöol. Exper., iv, p. 364, 1875. R. Rathbun, Echinod. Brazil, p. 147, 1879. Ives, Proc. Acad. Nat. Sci. Philad. for 1889, p. 171. 
The rays are angulated and not very long; not slender. Radii of a medium sized specimen $12^{\mathrm{mm}}$ and $47^{\mathrm{mm}}$; ratio about as $1: 4$. On the dorsal and lateral surface of the rays there are about five irregular rows of rather distant, relatively large, stout, acute, conical spines, on mammilary bosses of the principal plates, and partially covered by a thick dermis. The two outer of these rows may be reckoned as superomarginals, but they are like the others.

The inferomarginals, which are on the actinal side near the adambulacrals, but separated from them by a naked lane, form a more regular row of about fifteen, somewhat larger than the dorsals, but similar in form.

The disk bears a few spines, like the radials. Beneath, the disk is covered by a smooth, naked dermis, without spines. Papular pores are numerous in large groups on the dorsal side; fewer on the sides and beneath.

The adambulacral spines are two to a plate; the outer one is much the larger and they form a close, regular, longitudinal row, partly webbed; the inner one is much smaller, not half as long, and situated deep in the furrow. Above description is from a Brazilian specimen.

In life this species is usually bright red or crimson; it becomes dull reddish brown in alcohol, and usually dark purplish brown when carefully dried.

Not uncommon in shallow water and on reefs throughout the West Indies. It extends to the Abrolhos Reefs, Brazil, and to Yucatan. Abundant in Bay of Bahia, Pernambuco, on rocky bottoms, etc. (R. Rathbun). Yucatan (Ives).

I have not seen it from Florida, nor from the Bahamas. The Yale Museum has it from the Abrohos Reefs, Brazil (coll. C. F. Hartt, No. 1527, type of $E$. crassispina), and young specimens, apparently of this species, from Parahyba de Norte (coll. Hartt, Nos. 5209, 5210, 5211).

\section{Echinaster modestus Perrier.}

Echinaster modestus Perrier, op. cit., p. 7, 1881. Etoiles de Mer, p. 206, pl. iii, fig. 7, 1884 .

The type was evidently a young specimen. Its radii were $6^{\mathrm{mm}}$ and $36^{\mathrm{mm}}$; ratio, $1: 6$. 
The dorsal surface is formed of openly reticulated plates, leaving large sunken papular areas, containing groups of three or four papulæ. The investing dermis is thick.

The dorsal, dorsolateral, and lateral spines are very small and form about nine irregular rows, with scattered spines between them. The marginals are not distinct.

Besides the nine rows there is a regular row of interactinal spines, which ceases at about midlength of the ray. The adambulacral plates have a short, thick, obtuse furrow-spine, and exterior to it, an equally larger but rather shorter spine; outside of this there may be, in the same transverse line, one or more small spines.

Taken by the Blake at two stations among the Lesser Antilles, in 120 to 123 fathoms, and in the Gulf of Mexico, off West Florida, in 101 fathoms.

This has much smaller spines than specimens of $E$. spinulosus of the same size, and the surface appears more areolated.

Thyraster serpentarius (M. and Tr.) Ives.

Echinaster serpentarius M. and Trosch., Syst. Ast., p. 24, 1842. Perrier, op. cit., vol. iv, p. 370, 1875. Lütken, op. cit., p. 285 [61], 1871.

Thyraster serpentarius Ives, op. cit., p. 329, pl. viii, figs. 19-21, 1890.

The genus Thyraster, established for this species by Ives (1890), is separated from Echinaster especially by the character of the dorsal and marginal plates, which are quadrangular, or rhombic, overlapping by their angles, and placed in regular longitudinal rows. They bear three or four small, thorny spines, in a row, on the distal edge. The adambulacral plates mostly bear a row of three or four small spines on the distal margin, with a small furrow-spinelet. The marginal plates usually have three spines on the distal edge, rather larger than those of the dorsal plates, but still quite small. Diameter of the type, 4 inches.

It is a Mexican species, recorded by Müller and Troschel, and later by Ives and others, from Vera Cruz.

Genus Henricia Gray.

Henricia Gray, Änn. Mag. Nat. Hist., vi, p. 184, November, 1840; Synopsis Starfishes, p. 5, 1866. Bell, Ann. and Mag. Nat. Hist., vi, p. 473, 1890; 
Catal. British Echinod., p. 95, 1892. Fisher, 1911b, p. 266. Verrill, op. cit., p. 209, $1814 a$.

Cribella Forbes, Brit. Starfishes, 1. 100, 1841, or December, 1840.

Echinaster (pars) Müller and Troschel, April, 1840; Syst. Aster., p. 22, 1842.

Cribrella Lütken, Gronl. Echinod., p. 30, 1857. Norman, Ann, and Mag. Nat. Hist., xv, p. 124, 1865. Verrill, Proc. Boston Soc. Nat. Hist., x, p. 345, 1866. Perrier, Revis. Stell. Mus., Arch. Zoöl. Exper., iv, p. 373, 1875. A. Agassiz, North Amer. Starfishes, p. 113, pl. xviii, 1877 (structure of skeleton). Viguier, Squellette des Stell., Arch. Zoöl. Exper., vii, p. 126, pl. vii, figs. 8-15, 1878 (odontophore). Sladen, Voy. Chall., xxx, p. 540, 1889. Perrier, Exp. Trav. et Talism., p. 143, 1894. Ludwig, Fauna Aretica, p. 473.

Stellate starfishes usually with five terete, slender rays; sometimes with short rays and wide disk. Sometimes with six or more rays in autotomous species.

Dorsal plates are numerous and small, united into a rather closely reticulated structure, bearing numerous papular pores, either isolated or in small groups. Dorsal spinules minute and nearly uniform, crowded in divergent clusters on the convex ossicles of the dorsal, lateral, and actinal surfaces.

The madreporic plate is inconspicuous and usually spinulose; sometimes two are present in autotomous species. There is no thick dermis over the plates.

Supermarginals are small, often indistinct, and like the dorsals. Inferomarginal plates distinct, often larger than the superomarginals, contingent with the latter distally, but often separated proximally by one, two, or more interpolated rows of marginal ossicles, varying in number and extent, and thus causing great variations in the thickness and taper of the rays. Interactinals and inferomarginals similar and closely joined, convex, and covered with small spinules; the rows are separated by papular pores, which may also occur between the interactinal and adambulacral plates.

The two rows of marginal plates, the interactinal and the adambulacrals agree nearly or quite in radial length, at least proximally, so that they form regular transverse series.

The adambulacral plates are transversely oblong. Their actinal face is covered with numerous spinules in two or more transverse rows, or in a compact group; those near the furrow margin are longer, and one to three may stand on the margin; there is one 
or sometimes two furrow-spines within the groove. Pedicellariæ have not been found in any species.

The eggs and young are carried in clusters around and below the oral region until the young take on the stellate form provided with sucker-feet.

This genus differs from Echinaster in the absence of a thick external integument; in the covering of minute spinules; and in the nearly uniform small ossicles of the dorsal and lateral skeleton, the connective ossicles being almost indistinguishable from the primary series; and in the quadrangular form and regular arrangement of the marginal and interactinal plates.

According to the accepted rules of priority it is necessary to adopt Henricia instead of Cribrella as the name of this genus, for it has at least a month of priority. Cribrella of Agassiz, 1835 , was a different group.

Henricia antillarum (Perrier). Verrill, 1914a, p. 210.

Cribrella antillarum Perrier, Bull. Mus. Comp. Zoöl., vol. ix, p. 8, 1881;

Etoiles de Mer, p. 207, pl. iii, fig. 3, 1884.

Rays, in the type, five, rather long, slender terete, regularly tapered. Radii $7^{\mathrm{mm}}$ and $42^{\mathrm{mm}}$; ratio, $1: 6$.

Dorsal ossicles small, reticulated, leaving numerous papular areas mostly smaller than the ossicles and containing a single papula. They are covered with numerous minute, short spinules. Madreporic plate single, raised, about midway between the center and margin of the disk, and covered with minute spinules similar to those of the dorsal ossicles.

Two marginal rows of plates are well developed, rectangular, closely covered with minute spinules.

There are two or three rows of interactinal plates proximally, but only one reaches the middle of the ray. Their larger plates are quadrangular and of the same length as the marginals and adambulacrals.

The latter are transversely oblong; their actinal surface is covered with small spinules; five or six of them become abruptly larger near the furrow margin and stand in two rows, two or three in each row.

Dredged by the Albatross at station 2671, off Georgia, in 280 fathoms. (No. 18,392, N. Mus.) 
Perrier recorded it from five Blake Exped. stations, in 127 to 734 fathoms, among the Lesser Antilles.

The specimen from off southern Georgia (No. 18,392) has the proximal interactinal plates transversely oblong or rectangular, and similar to the marginals in size and form.

The adambulacral spines are strongly differentiated; the three nearest the groove show a decided approach to the formation of a true marginal comb. Those next to these are about twice as long as those farther back. There is a small furrow-spine deep in the groove, and distally there may be two.

Small isolated papular pores form a row between the interactinals and marginals, and also between the former plates; a few are located proximally between the interactinals and marginals.

\section{Henricia sexradiata (Perrier) Ver.}

Cribrella sexradiata Perrier, Bull. Mus. Comp. Zoöl., vol. ix, p. 8, 1881; Etoiles de Mer, p. 209, pl. iv, fig. 6, 1884.

Henricia sexradiata. Verrill, N. Pacific Starfishes, p. 371, 1914a.

\section{Plate xi; figure 7. Details.}

Rays slender, variable in number, often unequal in size; most frequently there are six of which about three are shorter than the others, due to autotomy.

The type described by Perrier had the radii $6^{\mathrm{mm}}$ and $13^{\mathrm{mm}}$; ratio, $1: 2.16$; others have relatively longer rays.

The dorsal surface is covered with numerous small reticulated ossicles, carrying very small spinules; the papular areas are smaller than the ossicles and mostly have a single papula. Two madreporic plates are usually present, small, granulated, one each side of a single ray.

The two rows of marginal plates are very distinct; the plates are quadrangular and covered with nearly uniform minute spinules, a little larger than those on the dorsals. There is a short row of peractinal plates of similar size and form, proximally.

The adambulacral plates are transversely oblong; they bear, near the inner margin, about five small obtuse spinules, larger than the others, and forming two longitudinal rows; two belong to the inner or marginal row; three to the outer one. The rest 
of their actinal surface is covered with smaller, short, obtuse spinules, resembling granules.

Perrier recorded this species from the Blake Expedition from off West Florida, ${ }^{10}$ in 101 fathoms, and off Barbados in 150 fathoms. I have seen it, also, from Blake station 297, in 123 fathoms, off Barbados. The Bahama Expedition dredged it off Havana, in about 200 fathoms.

This may be only a variety or form of $H$. antillarum. Such differences as have been noticed may be due to the variations caused by autotomous division. The possession of six rays cannot be regarded as a specific character, especially in autotomous species.

\section{Henricia microspina Verrill, sp. nov.}

A small species with a small disk and five very slender terete rays. Radii of the type $4.5^{\mathrm{mm}}$ and $23^{\mathrm{mm}}$; ratio, $1: 5.1$.

The dorsal surface is evenly covered with very small irregular plates many of them roundish, forming a finely but rather evenly riticulated structure, in which the plates and ossicles are narrower than the sunken papular areas between them. The papulæ are mostly solitary. The madreporic plate is small, somewhat raised, nearly destitute of spinules.

The spinules are remarkable small and thin, almost microscopic in size, very slender and short. They are rather numerous on the larger plates, but are not crowded, partly owing to their thinness.

Plates of both marginal rows are very distinct, transversely oblong, nearly equal, and covered with numerous very minute, spaced spinules like those of the dorsals but a trifle larger. The two rows are separated only by a narrow naked groove distally, but at the base of the rays a few intermarginal plates lie between them.

The interactinal plates form a single regular row. They are squarish, about half as large as the marginals, and spinulated in the same way. There is a simple row of minute papular pores each side of the interactinal row of plates.

10 Perrier gives this station erroneously as No. 47. It should be No. 45. He also errs in giving the longitude as $33^{\circ} 21^{\prime}$ East. It should read $83^{\circ} 21^{\prime}$ East. It is in N. lat. $25^{\circ} 33^{\prime}$, Northrest of Dry Tortugas. 
The adambulacral spines are very characteristic. There is a strictly marginal comb, directed horizontally across the groove, and composed proximally usually of three slender spines, webbed at base. Distally these spines are reduced to two and near the tip of the ray to one. Deep in the groove there is sometimes a minute furrow spine, especially distally, but proximally it is usually lacking or rudimentary.

On the actinal face of the plate there are numerous minute spinules, of which four to six, near the inner margin, become decidedly longer than the rest.

The adambulacral plates and spines project strongly into the groove, but are so much separated serially that they leave large rounded interspaces for the passage of the sucker-feet, which appear to be larger than usual.

Taken by the Albatross at station 2655, in 338 fathoms, north of Bahamas, N. lat. $27^{\circ} 22^{\prime}$; W. long. $78^{\circ} 7^{\prime} 30^{\prime \prime}$. (No. 18,390, Nat. Mus.)

\section{Family Solasteridz Perrier.}

Solasterince (sub-family of Echinasteridæ) Viguier, Squellette des Stellerides, Nouv. Arch. Zoöl. Exper., vii, p. 133, pl. viii, figs. 1-7, 1878, (structure).

Solasteridke Perrier, Etoiles de mer, p. 210, 1854. Sladen, Rep. Voy. Chall., Zoöl., xxx, p. 442, 1889. Perrier, Exped. Trav. et Talism., p. 151, 1894. Fisher, op. cit., 1911b, p. 305. Verrill, op. cit., 1914a, p. 242.

Echinasterida (pars) Perrier, Revis. Stell., Nouv. Arch. du Mus., iv, p. 358, 1875.

Rays varying in number from five to thirteen or more. Dorsal skeleton generally formed either by openly reticulated or loosely imbricated (rarely detached) ossicles, which have a convex or elevated central boss, bearing a cluster of slender paxilliform movable spinules, webbed together into stellate or pencillate groups (pseudopaxillæ). Both series of marginal plates are usually distinguishable, at least distally, alternate or opposite, or nearly in one line. The upper ones are often the smaller and essentially like the dorsal pseudopaxillæ. Both rows bear paxilliform spinelets.

Actinal interradial pseudopaxilla are generally present and similar to the dorsals. Adambulacral plates are transversely elongated and bear, each, one to five or more spines, usually 
webbed, in a longitudinal row on the inner margin of the groove and one or more clusters or a transverse webbed series or comb of movable spines on the outer surface. True pedicellariæ are not known in most species, but large specimens sometimes have a few small bifid spines in the furrow series, and in S. stimpsoni a few minute simple bivalve pedicellariæ sometimes occur on the dorsal paxillar areas. Sladen (1888 and 1889) divided this family into two subfamilies: Solasterince and Korethrasterino. In this he was followed by Perrier (1894, pp. 154, 158). Later these have been considered separate families.

\section{Genus Lophaster Verrill.}

Lophaster Verrill, Amer. Journ. Sei. ser. III, xvi, p. 214 (type, L. furcifer), 1878. Expl. Albatross in 1883. Ann. Report U. S。 Fish Comm., pp. 531, 541 [29, 39], pl. xvi, figs. 49, 49a, 1885. (L. furcifer); Amer. Journ. Sci., xlix, p. 201, 1895. Sladen, Voy. Chall., xxx, pp. 458-461, 1889. Fisher, op. cit., $1911 b$, p. 334.

Lophaster Verrill, op. eit., $1914 a$, p. 366 .

Solaster (pars) Danielssen and Koren, Asteroidea, Norske Nordhavs-Expd. Zoöl., xi, p. 47, pl. viii, fig. 12 ; pl. ix, figs. 9-11, 1884 (structure). Sarkaster Ludwig, Mem. Mus. Comp. Zoöl., vol. xxxii, p. 185, 1905 (t. Fisher).

Rays nominally five, sometimes six. Disk not very broad. Dorsal surface covered with nearly uniform paxilliform plates (parapaxillæ) which have a columar or raised boss, and a lobed polygonal or cruciform base; their lobes are articulated by overlapping, without intermediate ossicles, and thus form a closely reticulated structure with polygonal or subquadrate meshes, and usually solitary papulæ.

Marginal plates of both series well developed, in regular series, parapaxilliform, like the dorsals, but larger.

Interactinal plates closely united in interradial angles, with paxilliform spinules; a single row usually extends far along the rays in adult specimens, with or without spinules. Adambulacral plates have a furrow series of webbed spines, and a transverse comb on the actinal surface.

Species of this genus have been found in deep water, in all the oceans. 
Lophaster Radians Perrier.

Korethraster radians Perrier, Bull. Mus. Comp. Zoöl., vol. ix, p. 12, 1881. Korethraster hispidus Perrier, Etoiles de Mer, p. 212, pl. vi, figs. 9-11, 1884 (non W. Thompson).

Solaster radians Perrier, Etoiles de Mer, p. 275 (in explauation of plates), pl. vi, figs. $9,10,11,1884$.

Lophaster radians Perrier, op. eit., pp. 167-170 (in lists of species), 1884.

Korethraster? radians Sladen, op. eit., p. 459 (footnote), 796, 1889.

Plate v; figure 2. Plate vii; figure 3. Plate xi; figures $1-1$. .

Form stellate with a rather broad convex disk and short subacute rays. Radii of the largest (sta. 64 ), $17^{\mathrm{mm}}$ and $40^{\mathrm{mm}}$; ;ratio, $1: 2.4$. It occurs with four to six rays, usually five. The dorsal skeleton is rather openly reticulated with large quadrangular papular areas and numerous large grouped papulæ.

The pseudopaxillæ are rather large and high, with an enlarged convex summit, which is covered with numerous (often forty to fifty) very slender, divergent, thorny spinules; those of the marginal fringe are longer and interlock across the spaces intervening between the plates. The spinules are hyaline and often forked at the tip, and diverge in all directions.

On the rays there is no evident median series, nor do the plates form many regular transversely oblique rows on the sides. The bases of the plates are mostly deeply four-lobed or substellate. Their arrangement is evidently in radial rows.

The two marginal rows of plates are very evident and pretty regular, and nearly opposite. The upper ones are rounded and very similar to the larger dorsals, and higher than the adjacent lateral ones. The inferomarginals are high, elliptical and nearly twice as large with a correspondingly larger number of terminal rough spinules on the convex summit.

There is a row of small peractinal plates, extending to about the distal fourth of the rays, and a few other interactinal ones on the small interradial areas. These have very slender, thorny spinules.

The adambulacral plates have a prominent convex inner margin, which bears a regular compact row of four or five long, slender, thorny, subhyaline furrow-spines, the middle ones longest. Their actinal surface bears a row usually of three or four similar rough spinules, but rather stouter. In this dry specimen there is no very evident web between these spines, except near 
their bases. It is more evident in others, but it is thin and delicate.

The oral plates are large and have a broadly and evenly rounded margin, that of the pair combined forming a semicircle, and bearing along the edge a very regular compact row of eighteen slender subequal spines, nine to each plate. Epioral spines are also numerous and slender.

Ambulacral sucker-feet and their pores are very large, regularly biserial.

The type described by Perrier was smaller, radii $4^{\mathrm{mm}}$ and $10^{\mathrm{mm}}$.

Perrier, in his report on the starfishes of the Blake Expedition (1884, pp. 167, 212, and 275), placed this species in three distinct genera, and under two different specific names (without explanations or cross references), as shown in the synonymy given above. His description was given under "Korethraster hispidus, sp. nov." ; but it was a reprint of his earlier description (1881), which was given under Korethraster radians.

The name, Lophaster radians, occurs in his lists of species dredged; and Solaster radians occurs only in the explanation of plate vi. There is no reference to these figures in connection with the description. I am not aware that he corrected these references in any other later works.

The type of this species, described by Perrier, was quite young (radii $4^{\mathrm{mm}}$ and $10^{\mathrm{mm}}$ ), only about one-fourth as large as the one now described. This will account for various differences.

Perrier recorded this species from off Barbados, in 56 fathoms, and off Havana, in 80 fathoms. It was also dredged at several stations in the West Indies, by the "Albatross."

It was taken by the Bahama Expedition at several stations. The largest, described above, was from station 64, in 110 fathoms, off Florida. Smaller ones occurred at sta. 28, off Sand Key, in 116 fathoms; and at sta. 56, Pourtales Plateau, in 200 fathoms. Another (radii $10^{\mathrm{mm}}$ and $33^{\mathrm{mm}}$ ) was from station 62 , off Florida, in 80 fathoms.

Genus Solaster Forbes.

Solaster (pars) Forbes, Mem. Wern. Soc., viii, p. 120, 1839; British Starfishes, p. 109, 1841. Gray, Ann. and Mag. Nat. Hist., vi, p. 183, November, 1840; Synopsis, p. 4, 1866. Verrill, Proc. Boston Soc. Nat. 
Hist., x, p. 345, 1866 (Solaster and Crossaster first separated). Agassiz, North American Starfishes, pp. 111, 112, 1887 (structure). Perrier, Exped. Trav. et Talism., p. 154, 1894. Sladen, op. cit., p. 450, 1889. Verrill, North Pacific Starfishes, p. 242, 1914a.

Solaster (pars) Viguier, Nouv. Arch. Zoöl. Exper., vii, p. 138, 1878 (structure).

Solaster (pars) Danielssen and Koren, Norw. N. Atlantic Exp., Asterioidea, pp. 42, 52, 53, 1884 (structure). Fisher, op. cit., 1911b, p. 306.

Crossaster (pars) Müller and Troschel, Monatsb. Preuss. Akad. Wiss., Berlin, April, 1840, p. 103.

This genus includes large, handsome, multirayed species, usually with a broad disk and slender rays.

The rays are seven to fifteen, variable in each species, but most frequently ten to twelve. Dorsal ossicles small, mostly slightly four-lobed, sometimes stellate, usually reticulated, or in quincunx, on the disk and proximal part of the rays, but closely imbricated near ends of the rays, and often arranged in regular quincunx order on the sides of the rays. They are convex or mammillate, with a central boss, and bear a stellate or fasciculate cluster of slender spinules, webbed together, and usually enclosing one or several central spinules, connected by the web, forming pseudopaxillæ. The outer circle of webbed spinules often forms a funnel-shaped structure in life, or when well preserved; but the spinules are movable, and in dry specimens they are usually mostly collapsed or tipped over, thus forming irregular groups or pencils of small spinules, from five to twenty or more in a group.

The superomarginal plates are small and close to the larger inferomarginals, usually alternating. They are frequently hardly distinguishable from the dorsal pseudopaxillæ, except near the ends of the rays, but they extend regularly to the apical plate.

Inferomarginals are much larger and more elevated, usually transversely oblong, forming a rather conspicuous row. They bear a large number of paxilliform spinules in two or more transverse rows. Adambulacral plates usually have three to six shorter groove-spines, webbed together, and an actinal transverse row of four to nine or more longer spines, also webbed.

The interradial actinal areas are small, but distinct, and bear pseudopaxillæ, much like the dorsal ones.

Papulæ are numerous on the dorsal surface, but stand singly 
or in small groups. A single row of peractinal pseudopaxillæ usually extends along the proximal part of the rays, to about the middle.

Solaster CARIBbeus Verrill, sp. nov.

Plate xxviii ; figures $1-1 a$. Type.

Disk rather large ; rays seven or eight; most often eight, rather short. Radii $14^{\mathrm{mm}}$ and $36^{\mathrm{mm}}$; ratio, $1: 2.6$.

The rays are rounded above and taper regularly. They are closely covered with very small, elevated pseudopaxillæ, having very small spinules. Papulæ are numerous, but mostly solitary. Both rows of marginals are distinct and alternate. The upper ones are much the smaller, compressed, and not much larger than the dorsals.

The inferomarginals are more than twice larger, transversely oblong, and bear two or more rows of short spinules.

The adambulacral plates have an inner or furrow-comb of three or sometimes four graded, webbed spines, the middle ones longest; and a transverse actinal comb of about four larger tapered spines, of which the second and third are the larger.

The jaws have a peroral row of about eight relatively long, tapered, subacute, graded spines (four on each side), of which the two middle ones are considerably longer and larger than the next, while the latter are about twice as long as the third.

All the specimens are quite young. Taken by the Albatross at several stations in the West Indies.

Family Korethrastermo Dan. and Kor.

Korethrasteridce Danielssen and Koren, Asteroidea, Norske Nordhavs-Expd. Zoöl., xi, p. 99, pl. xii, figs. 1-14, 1884 (structure). Fisher, op. cit., $1911 b$, pp. 252, 340 .

Korethrasterince (subfamily of Solasteridæ) Sladen, op. cit., p. 462, 1889. Perrier, Exped. Trav. et Talism., pp. 151-154, 158, 1894 (descr. and analytical table).

Stellate starfishes with short rays and convex disk, flat below. Dorsal surface covered with thin, flat, roundish plates, overlapping by their edges, with a boss in the middle, bearing a fascicle of long, divergent spinules. Inferomarginal plates are trans- 
versely elongated, their outer ends forming the margin, and bearing spines.

Adambulacral plates correspond with the inferomarginals and join them. They bear a transverse row of slender spines, usually without webs. Interactinal plates are usually lacking.

Jaws carinate, with a row of several adoral spines and a larger terminal pair; actinal surface with a pair of larger epioral spines.

Dorsal papulæ are said to be lacking in the type genus; they are present in Remaster.

Genus Remaster Perrier. Type R. palmatus Per.

Korethraster (pars) Perrier, op. cit., 1881, p. 12; Etoiles de Mer, p. 211, 1884.

Remaster 12 Perrier, op. eit., pp. 150, 161, 1894 (as subgenus).

Dorsal plates have a four-lobed base, the lobes overlapping, leaving large papular pores between them; from the central boss arises a divergent circle of slender webbed spinules.

Inferomarginal plates form the border and bear marginal spines. Two or three rows of imbricated interactinal plates on the rays, corresponding to the adambulacrals, and bearing about two webbed spines. The jaws have large epioral spines.

\section{Remaster palmatus Perrier.}

Korethraster palmatus Per., Bull. Mus. Comp. Zoöl., ix, p. 12, 1881; Nouv. Arch. du Mus., vi, pp. 311, 376, pl. viii, figs. 5, 6, 1884. Sladen, op. cit., pp. 463, 796, 1889.

Korethraster Nutting, Narrative, p. 167, 1895.

Remaster (subgenus) palmatus Per., Exp. Trav. et Talism., pp. 158, 161 (redescribed), 1894.

\section{Plate xi ; figure 2.}

The type of Perrier had the radii $4.7^{\mathrm{mm}}$ and $14^{\mathrm{mm}}$; ratio, $1: 3$.

The form is stellate, with a swollen disk and short rays.

On the dorsal surface a deep interradial groove runs up to the dorsal pore, dividing the disk into five parts. The dorsal pore is surrounded by granules, but has no visible plates.

Five primary radial plates are distinguishable. The rest of the radial areas are covered by squarish plates, with emarginate

12 The name refers to the large flat oral spines (t. Perrier.) 
sides and rounded angles, and imbricated by the two distal lobes of each, overlapping the edge of the two plates beyond it. Thus each plate joins four others.

Each dorsal plate has a round central boss, carrying a fascicle of ten to twelve long (about $1^{\mathrm{mm}}$ ), slender, movable, webbed spinules capable of becoming either divergent or fasciculate. Two large isolated papular pores are situated on the adoral side of each plate in the notches.

The adambulacral plates are short, but elongated transversely. Each has a single small furrow-spine, and on its actinal side three large flat, striated spines, truneated and fringed at the tip, each of which seems to be composed of three united slender spines. These form three longitudinal rows.

Outside of the adambulacrals is a range of imbricated plates, corresponding to them in length, but a little oblique. Each of these bears a flat fascicle of coalesced spinules like those of the adambulacral plates. These are succeeded by an outer row of similar, but less regular, plates which form the margin of the under side.

Each jaw-plate bear's a large, flat, lanceolate, hyaline spine, turned outward and appressed. Other oral spines are small and webbed together.

Ambulacral feet are rather large, in two regular rows, with well developed suckers.

The type was taken by the Blake off Barbados, in 163 or 200 fathoms, with three others; a young one was taken near the same place in 76 fathoms. It was also dredged in the West Indies by the Albatross.

Taken by the Bahama Expedition at station 56, on the Pourtales Plateau, N. lat. $20^{\circ} 16^{\prime}$, in 200 fathoms (3 specimens).

\section{Family Asterintde.}

Asterinidae (pars) Gray, Ann. and Mag. N. Hist., ri, p. 238, 1840; Synopsis, p. 15, 1866. Perrier, Revis. Stell., iv, p. 291, 1875; v, p. 209, 1876. Viguier, Squellette des Stell., Arch. Zool. Exper., vii, p. 205, pl. xiv, figs. 1-13, 1878 (structure). Sladen, Voy. Challenger, xxx, p. 374, 1889. Perrier, Expl. Trav. et Talism., pp. 141, 163, 1894. Fisher, op. cit., 1911, p. 253 (Table of genera). Verrill, Revision Asterininæ, Amer. Journal Science, vol. xxxv, p. 477, 1913 (Table of genera); Starfishes North Pacific Coast, p. 262, 1914a. 
Body usually rather flat, often thin, sometimes stellate with long rounded rays; usually with five or six short rays, rarely up to eight. Margins usually thin and formed mainly by the inferomarginals; superomarginal plates small, usually scarcely larger than the adjacent dorsals, generally with a comb or cluster of spinules. Dorsal plates usually lobed or cross-shaped, flat and more or less imbricated, sometimes not imbricated; generally covered with minute spinules, often in tufts or combs; sometimes covered with a soft, naked, or granular dermis. Ventral side flat; interactinal plates angular, flatish, imbricated or closely united, usually covered with small combs or tufts of spinules, sometimes with only one; these plates form regular oblique rows. Adambulacral spines simple, divergent; generally in two sets; the furrow-spines form small, usually webbed combs of two to eight. Those on the outer surface are in groups or fans, like the interactinals, or single. Pedicellariæ usually lacking; when present they are two-bladed, erect, forficiform.

There is generally no single, dorsal, median, radial row of plates; its place is taken by two, three or more alternating rows; the larger of these plates have a papular pore or several pores under the proximal edge. In some cases, especially while young, there is a symmetrical median row of plates. These larger plates usually show only one of the edges and part of one side; seen from the inside they appear much larger, often four-lobed, and obliquely imbricated. The dorsal plates of the outer interradial areas, in many species, have conical or pillar-like processes extending downward and meeting similar uprising processes from the outer interactinal plates, as stalactites meet stalagmites; or they may not join directly, but be united by an intermediate ossicle. In some genera they are differently joined. In typical Asterina, and doubtless in many other genera, if not in all, the genital pores are on the ventral side, in a pair, just outside the jaw plates, but they are seldom visible in preserved specimens. The madreporic plate is usually rather large and placed close to the central area of the disk; sometimes there are two or more, rarely five.

The papular pores are dorsal and form several rows on the median and lateral parts of the rays, and sometimes on adjacent parts of the disk, but are absent from the more or less extended 
interradial areas, where the plates are more closely imbricated and different in shape.

Asterinides Verrill. Type, A. folium (Ltk.)

Asterina (pars) Lütken; Sladen; Perrier, etc.

Asterinides Verrill, Revision Asterinæ, pp. 477, 482, 1913. N. Pacific Starfishes, p. 263, 1914a.

Margins of disk and rays thin, subacute; rays short, depressed. Interactinal or ventral plates in regular oblique rows, each with a fan-shaped group of two to eight small spines, usually webbed.

Dorsal plates of papular areas thin, nearly all of one kind, the exposed part usually roundish, elliptical, or shield-shaped, wholly or partly spinulose. Principal dorsal plates are all closely imbricated. Small interpolated plates few and mostly solitary. Adambulacral spines form a fan or comb within the furrow-edge, and another fan on the outer surface; ventral plates and interspaces are not covered by a granulated dermis. No pedicellariæ occur on the dorsal plates nor on the intervening dermis.

This genus differs from typical Asterina, type, A. gibbosa, ${ }^{13}$ chiefly in lacking the characteristic pedicellariæ of that genus. Its dorsal plates are also thinner and more scale-like, more closely imbricated, and often partly naked and areolated.

\section{Asterinides folium (Lütk.) Verrill.}

Asteriscus folium Lütken, Vidensk. Nat. Foren., Kjobenhavn, p. 60, 1859. Asterina folium A. Agassiz, North Am. Starfishes, p. 106, pl. xiv, figs. 7-9, 1877. Sladen, op. cit., 1889, p. 393.

13 Asterina gibbosa (Pennant). This, which is the type of the genus and family, is from Southern Europe and the Mediterranean Sea.

It has the following characters: Dorsal plates, in the papular areas are thick, subequal, imbricated; their exposed proximal ends are rounded, convex, with the margin obtuse and bearing a cluster, usually of four to six small, rather stout, divergent, blunt spinules, and more or less numerous two-bladed pedicellariæ, both on the plates and between them, nearly as thick as the spinules; naked portion of the plates is finely areolated. The median plates of the rays are scarcely larger than others; usually there is a band of four alternating rows on the median area, with no special median row, unless in the young. The plates of the median radial areas are shieldshaped, with a pair of papular pores on the proximal edge, one either side 
Asterina minuta Gray, (non Gmel., nec Brug.14) Ann. Mag. Nat. Hist., p. 289, 1840; Synopsis Starfish, p. 16, 1866. Perrier, Arch. Zoöl. Exper. et Gen., v, p. 229, 1876.

Asteriscus folium Verrill, Trans. Conn. Acad. Sci., i. p. 74, 1867.

Asterina folium Verrill, Trans. Conn. Acad. Sciences, vol. xii, p. 281, pl. xxxiv, c, figs. $3, a, b, 1907$.

Asterinides folium Verrill, Revision Asterininæ, p. 479, figs. 1913a; Star. fishes N. Pacific, p. 263, $1914 a$.

Plate iii ; figure 5. Plate xi; figure 4. Plate xxviii; figure 2.

The rays are usually five; sometimes six or four. The dorsal plates are usually nearly naked, often bearing only a single or double range of small and short spinules on the most elevated portion. Dorsal radial plates are shield-shaped, notched for the isolated papular pores. Papular pores form six simple radial rows. They are absent from the interradial areas.

Plates of the interradial areas are closely imbricated, not lobed; their exposed part is more or less rhombic.

The interactinal plates are closely united; each bears a fan of usually three or four, sometimes five on the larger ones, of slender webbed spinules.

Adambulacral plates have, in the furrow-comb, about four slender spines, and three or four in the actinal cluster. The madreporite is near the central area of the disk. There are no pedicellariæ.

A specimen before me, from Curacoa, has the radii $6^{\mathrm{mm}}$ and of the median angle, in an emargination of the edge. Snzall intermediate plates are few and isolated.

The papular pores form abont fourteen to eighteen short rows, extending nearly to the margins and leaving ouly small interradial areas without pores.

Adambulacral furrow-spines slender, in regular combs of three to five; those on the outer surface are much stouter, mostly two to a plate. Interactinal plates closely united, mostly with two acute spinules to a plate.

Marginals very small, those of the two rows subequal, convex, finely spinulose.

The pedicellariæ have the basal piece swollen, ovate, larger than the tapered acute blades. They stand at all angles on dry specimens, but were probably erect in life.

14 The Asterias minuta of Gmelin, 1788, and of Brugières, 1792, is without much doubt the same as $A$. exigua Lam., but certainly not the present species. 
$11^{\mathrm{mm}}$; ratio, $1: 1.8$. It is the same one from which figures of the details of structure have been made.

The rays are convex; ends obtuse. All the plates of the upper side were naked, as received, dried. Probably they had some spinules originally. The plates are minutely punctulate, and closely imbricated.

Two alternating rows of plates, slightly larger than those adjacent, take the place of a median radial row. They are angularly shield-shaped. The adcentral edge is slightly raised and emarginate to accommodate the single papula standing there. No small intermediate plates are now left.

The plates in the rows of the sides of the rays, where there are papular pores, are similar to the median ones, but slightly smaller and mostly notched for the papula. They are somewhat oblique or one-sided.

The papulæ are in six rows on the rays; others are on the disk. The central dorsal pore is easily seen. The madreporic plate has a small convex, round, grooved top, but the basal part is considerably larger, with lobed margin, and has no gyri.

The adambulacral plates have four very slender graded spines in the marginal comb, and a close group of two, or sometimes three larger ones, on the actinal surface. The interactinal plates have mostly two or three small spinules. The apical peroral spines are large and acute. Curacoa, No. 7469 (Nat. Mus. coll.).

The color, in life, seems to be quite variable. At Bermuda, where I found it common, adhering to the under side of large flat masses of limestone, it was always of a pale, but distinct, blue color.

This small species is the most common shallow-water member of the family, from the Florida Keys and reefs to the Lesser Antilles and to the Bahamas and Bermudas. Curacoa (Yale Mus. specimen described). Perrier (1876) recorded ten specimens from Guadeloupe, among which one had four and another six rays. The Bahama Expedition took it at the Tortugas (one specimen was six-rayed), Jamaica (Clark).

Bermuda, common under large stones. Old Providence (Yale Mus.).

The only closely related species is $A$. modesta Verrill, from 
Panama. For the sake of comparison a revised description of the latter, from the type, is given here.

$$
\text { Asterinides modesta Verrill. }
$$

Asterina modesta Verrill, Trans. Conn. Acad. Sci., vol. i, p. 277, 1867.

Asterinides modesta Verrill, op. cit., p. 482, 1813.

\section{Plate xxvii; figures 1-2.}

Rays five, short. Dorsal radial plates are thin and closely imbricated, with a convex outer surface; beneath concave, over the isolated papular pore. A solitary, small, rounded plate stands adcentrally to the papular pore; it bears a tuft of small, slender spinules like those of the larger plates. The latter have, near their higher margin, a row, usually single, of small, slender, acute, divergent, thorny spinules. Pedicellariæ are lacking.

The interactinal plates are few, convex, minutely punctulated. Most of them bear a comb or fan of two or three slender spinules.

Adambulacral plates have a furrow-comb of about three slender, tapered spinules.

Panama and Pearl Islands at low tide. (Yale Museum.)

Genus Enoplopatiria Verrill. Type, $E$ marginata (Hupé). Enoplopatiria Verrill, Revision Asterininæ, p. 480, 1913a. Starfishes N. Pacific, p. 263, 1914a.

Dorsal plates are imbricated; a median radial row is distinct in the young. The principal plates of the papular areas have the exposed portion usually elliptical, curved, or crescent-shaped, prominent and spinulose; small interpolated plates are present in small groups or solitary. Ventral plates have a fan of two to five spinules; adambulacrals have a furrow-comb of three to five or more spines. Pedicellaria are present on the dorsal plates, especially on the small interpolated plates.

In this group the papular area is plainly differentiated on the rays; it consists, in the adults, of about four or five median and submedian rows of larger and broader, four-lobed or five-lobed plates, curved and notched proximally for the papular pores, and of two or three rows of narrower, obliquely placed, lobed plates, having an angular proximal lobe, and notched proximally over the papular pore. 
Between all the larger plates are a few small rounded plates, either solitary or in small groups, and often bearing a single bivalved pedicellaria.

On the dorsal interradial areas, beyond the papulæ, the plates are smaller, closely imbricated, subtriangular or pelecoidal, thickened, usually with a solitary small ossicle between their angles.

\section{Enoplopatiria marginata (Hupé) Verrill.}

Asteriscus marginatus Hupé, Voyag. Castelneau, Zoöl., iii, p. 100, 1857. Perrier, Pedicell., p. 97, 1869.

Asteriscus braziliensis Lütken, op. eit., 1859, p. 57.

Asteriscus stellifer Mobius, Hamburgur Abhand. Geb. Natur., iv, 1859.

Verrill, Trans. Conn. Acad., i, p. 343, 1867.

Asteriscus minutus (pars) M. and Tr., System Aster., p. 41, 1842. (non L., non Gmel., nec Gray, etc.)

Enoplopatiria marginata Verrill, Revis. Asterininæ, p. 480, 1813; Starfishes N. Pacific, p. 263, 1914a.

\section{Plate vii ; figure 2. Brazil.}

Depressed, stellate, with short, rather obtuse rays, and rather evenly incurved interradial margins. Becomes $65^{\mathrm{mm}}$ or more in diameter. Larger dorsal plates rather conspicuous with thickened exposed portions, mostly broad crescent shaped. The larger ones bear a curved single or double row of about six to twelve spinules, not covering the whole surface, and usually several forked pedicellaria, with a large rounded basal piece, nearly as thick as the spinules. A similar pedicellaria is usually borne on each of the small interpolated plates.

Small specimens, up to $70^{\mathrm{mm}}$ in diameter, usually have a distinct median dorsal row of subrhombic or shield-shaped plates, flanked on each side by a row of obliquely placed plates of similar size, but less symmetrical. Larger specimens usually show the median row of plates proximally, but on the distal third or half of the ray the dorsal rows of plates become confused and erowded irregularly.

The plates of the dorsal interradial areas are regularly imbricated in alternating rows, becoming thicker proximally, and often have a small central boss. They bear a group of small divergent spinules.

The ventral or interactinal plates are regularly arranged in 
oblique rows, thickened or convex, with a finely areolated surface, and bearing a central fan of two to five or more spinules. The smaller specimens usually have only two or three spinules; larger ones may have four or five on the proximal ones and two on the distal ones.

The proximal plates are so arranged that in the dry specimens a distinct pore, similar to the dorsal papular pores in size, is situated between their angles, but whether occupied by a papula cannot be ascertained from the dry specimens. The furrowseries of spines form a regular graded, webbed comb of about four or five on each plate, the central spines longer. On the actinal end of the plate there are usually two to four webbed spines, in a fan, the number increasing with the age.

West Indies; Colon; south to the Abrolhos Reefs, and Rio de Janeiro, Brazil. West Africa; Senegal (Perrier); Canary Islands.

Perrier records a six-rayed example from Brazil.

The Yale Museum has specimens from Rio de Janeiro (coll. C. F. Hartt, No. 5205) and other localities.

Perrier and several others regard the West African species (E. stellifera [Mob.]) as identical with that of the American coast. I have seen no African specimens and cannot express any personal opinion as to their identity.

The following species, from Panama, is very closely related to the above.

\section{Enoplopatiria siderea Verrill.}

Enoplopatiria siderea Verrill, Revision Asterininæ, p. 480, 1913; Starfishes N. Pacific, p. 365, pl. cix, fig 3, 1914a.

Plate xxvii; figures $3-3 a$. Type.

This is a rather large species. The type (dry) has the radii $24^{\mathrm{mm}}$ and $45^{\mathrm{mm}}$; ratio, $1: 1.83$.

It differs from the preceding in having the principal papular plates larger, thicker, more deeply lobed, and more finely areolated; in having the distal, dorsal interradial plates more rounded, and provided with very regular stellate rosettes of five to seven slender, divergent, interlocking spinules, and often one 
central spine. Combs of ventral plates have two to four slender, tapered, subequal, webbed spines, but mostly three.

Furrow-spines are in convex combs of four or five slender, webbed spines. Ventral plates are covered with a tough dermis. Pedicellariæ are abundant, two-valved. Marginal plates small, convex, regular, about equal, regularly paired; lower ones are the more prominent.

Panama. One dry specimen, presented by Capt. Dow (Yale Univ. Mus.).

Genus Asterinopsis Verrill. Type, A. penicillaris (Lam.). Asterinopsis Verrill, Revision Asterininæ, p. 480, 1913.

This genus is peculiar in having a fascicle of slender spinules on the ventral plates, instead of a fan-shaped group, which is usual in the family. Pedicellariæ are lacking. The dorsal and marginal plates also bear fascicles of slender spinules. Adambulacral furrow-spines are in regular combs. The principal dorsal plates are lobed or cross-shaped.

In addition to the type, which is Indo-Pacific, this genus includes the following two species.

\section{Asterinopsis pilosa (Perrier) Verrill.}

Asterina pilosa Perrier, Bull. Mus. Comp. Zoöl., vol. ix, p. 16, 1881; Nouv. Arch. Mus., vi, p. 219, pl. iii, fig. 8, 1884.

Asterinopsis pilosa Verrill, Revis. Asterininæ, p. 480, 1913.

This species was described from a single six-rayed specimen; radii $6^{\mathrm{mm}}$ and $10^{\mathrm{mm}}$.

It is evidently very closely related to the $A$. lymani and may not be distinct from it. As in the latter the ventral and dorsal plates bear fascicles of elongated, slender spinules, appearing silky. They agree in having six rows of papulæ; four slender spines in the furrow-combs; and in most other respects. Off Dominica I., 118 fathoms, Blake Expedition.

Asterinopsis lymani (Perrier) Verrill.

Asterinopsis lymani Verrill, op. cit., 1913, p. 480.

Asterina lymani Perrier, Bull. Mus. Comp. Zoöl., vol. ix, p. 15, 1881 ; Nouv. Arch. du Mus., vol vi, p. 219, 1884. 
The following notes were made by me several years ago, on the type specimen preserved in the Museum of Comparative Zoölogy.

Rays unusually long for this group. Principal dorsal plates are small, lobate or cross-shaped, separated by numerous rather large papular pores; they bear close pencils of rather long, slender spinules, ten or twelve or more in each pencil. The spinules of the plates in the interradial areas are more slender and divergent.

On the actinal side the outlines of the interactinal plates are not distinguishable; each plate bears a group or pencil of four to six very slender, long, acute spinules, longer than those of the dorsal plates. Marginal plates very prominent, but not very large; not flat. Each bears a terminal close cluster of long, slender spinules, like those of the interactinal plates. The adambulacral plates bear a comb of about four or five slender, acute, regularly placed spinules in the furrow-series, and a group of three to six similar spinules on the outer surface.

The type was dredged by the Blake Expedition, off Barbados.

Genus Stegnaster Sladen. Type, S. wesseli Per.

Stegnaster Sladen, Voy. Chall., xxx, p. xxxiv, 376, 1889. Fisher, op. cit., p.

254, 1911b. Verrill, Revision of Asterininæ, p. 481, May, 1913.

Form depressed, pentagonal or stellate, with very short rays; margin thin.

Adambulacral spines form a continuous webbed series, the individual combs of three to five being united together; no spinules on the outer surface. Dorsal and ventral plates imbricated and, like their interstices, covered with a finely granulated dermis, which also forms a web between the minute spinules forming a feeble fan, on the interactinal plates. No dorsal spinules. Papular pores form six or more rows on the rays. Internal dorso-ventral columns are present near the margins. Form depressed, pentagonal, with thin margins. A few small ossicles occur between the dorsal plates; usually solitary. No pedicellariæ have been observed.

Besides the typical species, this genus seems to include $S$. inflatus Hutton, of New Zealand. 


\section{Stegnaster wesseli (Perrier) Sladen.}

Asterina wesseli Perrier, Arch. Zoöl. Exper. et Gen., vol. v, p. 231, 1876; Etoiles de Mer., p. 220, 1884.

Stegnaster wesseli Sladen, Voy. Chall., xxx, p. 778, 1889. Verrill, op. cit., p. $481,1913$.

Plate iii ; figures $3,3 a$.

The form is pentagonal with emarginate sides, or substellate, with very short, wide rays. Radii of one of the larger specimens, $16^{\mathrm{mm}}$ and $20^{\mathrm{mm}}$; ratio, $1: 1.5$. No. 758 , Yale.

Central part of dorsal surface is convex. The dorsal surface is everywhere covered with a granulated dermis, both on and between the plates. The granules are minute, but sharp and rough. The larger plates of the papular areas are convex, curved and deeply notched for the papular pores; in front of the notch is a small ossicle, bordering the pore proximally.

The interactinal plates are rather thick, closely imbricated, and covered, together with their interspaces, by a sharply and densely granulated dermis, which also invests the bases of the row of minute spinules; it also forms a continuous web nearly to the tips of the marginal adambulacral spines, uniting them in an unintermpted series to the ends of the rays; it also covers the jaws and peroral spines, the granules becoming there higher, like small acute spinules. Many of the interactinal plates bear a small transverse group or rudimentary fan of two to four very small, sharp spinelets, which are much obscured by the surrounding granulated skin. The granules are pointed, rough, and crowded.

The furrow-spines are sub-equal, slender, obtuse, mostly two or three to a plate, standing in a nearly straight row.

Dorso-ventral pillars or trabecule are well developed, rather stout, often curved. Jaw-spines form a continuous series with about six or seven on each side, grading into and united with the adambulacral row; apical ones stouter. No epioral spines seen. A pair of small pores, probably genital, are situated in each interactinal area, one on either side of the convex outer end of the jaw-plates.

The central part of the dorsal side of the disk is surrounded by five larger and more prominent lunate plates, which are the 
basal radials or earinals. The madreporite, which is triangular, small, and depressed, is bordered externally by two smaller lunate plates, just outside the row of basal carinals.

The interradial areas, destitute of papulæ, are relatively extensive, running up in a narrow area, nearly to the central pentagon. The plates on the interradial areas are rhombic, closely united, and a little convex.

The median line of each ray is occupied by a row of small elliptical plates, elongated radially, without papulæ. The papular pores are large, round, and form six radial rows, where most developed; a few are situated on the central area of the disk. Superonarginal plates are transversely oblong, sometimes constricted across the middle, or double, and about twice as large as the roundish infero-marginals; the latter, however, project a little more and thus form the edge of the margin. Both series are covered with sharp granules, like the dorsals. No pedicellariæ were found.

\section{Variations.}

A somewhat smaller alcoholic specimen (diameter $28^{\mathrm{mm}}$ ) appears somewhat different. The principal dorsal plates are more distinet and appear more convex and more regularly arranged. The outlines of many of the plates can be seen under the granulated dermis. The upper marginal plates show their outlines beneath the granules. When the granules are cleaned off, they are oblong with rounded angles, with the longer axis transverse to the disk-margins. They are of the same width and number as the lower plates, and about twice as long, vertically. Their width is about the same as that of the adjacent abactinal plates, and they are covered with the same form of granules. Ventral interradial plates bear somewhat prominent flattened fans of minute spinules, webbed together at their base and showing three to seven small points at the outer edge. Jaw-plates are raised in the middle in the form of low verruce, covered with uniform and very small spinules. The peroral spines are slender, rather longer than the adambulaeral spines, and closely webbed together. The adambulacral spines are free only at the tips, the web being continuous along the whole length of the groove.

Off Florida; Bahamas; Jamica; West Indies generally; Colon (coll. W. F. Bradley, Yale Mus., No. 758). 


\section{Family Pornnime Perrier.}

Gymnasteriadee (pars) Perrier, op. cit., 1884, pp. 165, 229, Sladen, 1889, p. 355.

Poraniidae Perrier, op. cit., 1894, pp. 163, 227.

Asteropidce (pars) Fisher, Smithsonian Misc. Coll., vol. 52, p. 90, 1908; op. cit. 1911b, p. 247. Verrill (pars), op. cit., 1914a, p. 304.

Disk usually large; rays short and broad. Dorsal ossicles sometimes in regular radial rows, on subimbricated, more often irregular, sometimes partly abortive, either covered with a thick, smooth or granulated dermis, or spinulose.

Marginal plates sometimes prominent; often small; usually oblique or overlapping; the lower ones projecting, and often with a small group of spinules on the outer edge, or with a single spine.

Interactinal plates often numerous; usually in regular oblique rows or chevrons or else in rows running to marginal plates. Papulæ in dorsal radial areas; sometimes interomarginal. Pedicellariæ lacking.

Adambulacral spines may form a simple row, transverse to the groove, or there may be also an inner comb of two, three or more, often partly rubbed.

The structure of some of the genera is very much like that of the Asterinidæ, with which the group might, perhaps, be united as a subfamily, without doing violence to their natural affinities.

The genus Poraniella, recently described, is more nearly intermediate than any other.

It is intended here to separate those genera of Asteropidæ closely related to the type, and especially those having bivalve or trivalved pedicellariæ, as a distinet family of the Valvulosa. Poraniidæ appear to belong rather with the Spinulosa, next to Asterinidæ.

\section{Genus Poranielda Verrill.}

Poraniella Verrill, Annals and Mag. Nat. History, vol. xiv, p. 19, July, 1914 c.

Small starfishes with short rays. Dorsal surface covered with flat imbricated plates, in regular radial rows on the rays, not concealed by dermis, and bearing few spaced marginal spinules; medial radial row is distinct. Papulæ are isolated and placed under the proximal edge of the radial plates. 
Superomarginal plates well developed, larger than dorsals, naked, or with few spaced submarginal spinules.

Inferomarginal plates are about as large as the upper ones, more prominent and form the thin margin; their outer edge has a comb of slender spines; their upper surface has a second parallel row of small spines, no papulæ pores between the rows.

Interactinal plates are imbricated in regular chevrous, each of which, except the first, has an impaired median plate. Most of these plates have two or three spinules standing side by side, otherwise the plates are naked.

Adambulacral plates have a horizontal regular inner comb of about three small spines discontinuous with the spines on the actinal face, which stand in a transverse line, usually of two or three. This genus resembles Asterina and Asterinides pretty closely, not only in appearance, but also in the arrangement of the imbricated dorsal plates and their spinules, and the position of the papulæ. The plates are larger, however, and do not become so numerous and small toward the margins. The marginal plates are much larger, and thicker, and therefore the margin is not so thin and acute.

The interactinal plates and their spinules are much as in $A s$ terina, though larger and much fewer. The presence of a regular furrow-comb of adambulacral spines is another similar feature, though the spines on the actinal face stand in a transverse row, not as they do in Asterina.

This genus, therefore, is a sort of connecting link between Asterinidæ and Poraniidæ. Its affinities seem, on the whole, to be more with the latter, though the thick dermis found in most genera of the latter is lacking. The genus most nearly related is, perhaps, Lasiaster ${ }^{15}$ of Sladen, if this be distinct from the earlier genus Rhegaster Sladen, which is denied by some.

15 Lasiaster Sladen, op. cit., p. 371, 1889. All the plates, above and below, and both marginals covered with thick dermis and all have a compact cluster of numerous small spinules, but they are absent from the sutural lines. Superomarginal plates are rather large and their outlines are visible through the dermis. Inferomarginals not larger, but more prominent, finely spinulated on both sides and with a row of spinules on the outer end.

Adambulacrals have two furrow spines, nearly or quite side by side proximally and becoming oblique distally; actinal face has three spines in a 
Poraniella also closely resembles, in general appearance, Marginaster of Perrier. The type of the latter (so designated by Sladen, 1889) is $M$. pectinatus Per. (1881.) This has a different structure of the dorsal skeleton and very different adambulacral spines, which do not form a furrow-comb. In fact, it is covered with a thick dermis and is, without much doubt, the young of a large species of Porania or some closely similar genus. ${ }^{16}$

The Marginaster echinulatus Perrier, is nearer Poraniella in structure, for it has furrow-spines in a comb of two or three and a transverse row on the actinal face as in the latter.

Poraniella Regularis Verrill.

Poraniella regularis Verrill, Annals and Mag. Nat. History, vol. xiv, p. 19, July, 1914c.

Plate vii; figures $1-1 a$. Plate $\mathrm{xv}$; figures $5-5 b$. Details.

A small depressed stellate starfish, with a wide and somewhat convex disk and short, rapidly tapered, subacute rays, with rather thin fringed margins. Radii of the type, $6^{\mathrm{mm}}$ and $12^{\mathrm{mm}}$; ratio,

transverse row. Interactinal plates are in regular chevrons, each with a compact cluster of small spinules.

Type, L. villosus Sladen (1889), said by Sussbach and Breckner (op. cit., 1910 , p. 219), to be the same species as $L$. hispidus (Sars, 1871); P. rosea Dan. and Kor. (1884); Rhegaster murrayi Sladen (1883); Poraniomorpha spinulosa Verrill (1879); $R$. borealis Verrill (1878). See Plate $x$, figures $3,3 a$.

If this be correct, the name should be Rhegaster hispidus (Sars), for Rhegaster is six years earlier than Lasiaster. Our two New England species appear to me to be distinct and should be called Rhegaster spinulosus and $R$. borealis. See Verrill, 1914c, pp. 17, 18, pl. i, figs. $1 a, 1 b, 2$.

The latter is very closely related to $R$. murrayi, the type of Rhegaster. It differs in having the interactinal spinules longer and in special clusters, but the whole dorsal and marginal surfaces are densely clothed with uniform erect miliary spinules, entirely concealing the plates and sutures, as in Rhegaster. Whether either of our species is the same as Rhegaster hispidus (Sars) I am not able to say. That is the earliest name of any species; borealis is next in order (1878.) In Lasiaster the spinules do not cover the sutures, and therefore the outlines of the plates are more or less visible, and the superomarginal plates are larger and thicker. See also 1914c, in Annals and Magazines Nat. History, vol. xiv, pp. 17, 18.

16 I have before me equally small specimens of Porania insignis V. and Rhegaster spinulosus V., which agree very closely with Marginaster in details of structure. 
1:2. Marginal plates are eight in each row. The two series are not quite opposite.

The dorsal surface is covered with rather thin and relatively large imbricated plates, overlapping adcentrally, and adradially, forming rows subparallel with the median radial row. Two rows each side of the median radial row have plates larger than the median, flat, thin, imbricated toward the median, with the free edge curvilinear and slightly notched or crenulate, and bearing three to five minute, acute, marginal, appressed spinules. Rest of the surface without spinules and not obscured by dermis. Isolated sinall papula are situated adcentrally to these plates, one or two under the free edge of each, except distally. These are followed toward the interradial margin by two short curved rows of similar, but smaller, plates without papulæ between them.

The median radial row of plates is narrow but distinct. Close to the tip of the ray the plates are small and regular, angular, and lie flat, with no pores between. Soon they become notched and turned up with two papular pores under the free edge. Proximally they stand up nearly edgewise and become smaller and are depressed below the level of the adjacent rows of plates. They bear two or three minute acute marginal spinules. The basal radial plates are much larger, but stand up obliquely, showing only one edge and part of the side. Each bears five or six minute spaced spinules on the proximal margin, and three or four scattered on the surface.

At the base of the interradial areas are two similar closely joined or united plates, of larger size, with a notch between them, from which a narrow naked line runs down to the interradial margin. The small madreporite lies in, or partly above, the notch between two of these plates, which with the basal radials, form a raised rim, surrounding a central group of smaller plates, mostly rounded, and having few minute marginal spinules.

The superomarginal plates, which in the larger specimens number nine or ten, are rather larger and thicker than the radial plates, and a little convex, with curved outer and inner margins. Each one bears two (rarely one) small submarginal spinules on the outer side.

The inferomarginal plates are similar in size and number, but more prominent, with the edge rounded, forming a rather thin 
scalloped margin to the rays. Each bears two rows of spinules; a short row of about three on the upper surface, which are acute and divergent; and a marginal row, usually of four slender halfwebbed spines, the middle ones largest, so that the outline of the group is curved. On the under side they are naked, transversely oblong, and the surface is covered with microscopic, raised dots.

The interactinal plates form three regular chevrons, with a few additional small plates in the interradial angle. (In smaller examples there are but two chevrons). In the first series there may be twelve or more plates, all paired. In the second and third chevrons there is an impaired interradial plate. All these plates have two or three small acute spinules, near the aboral edge, standing side by side, and subappressed. The plates are somewhat imbricated, more or less ovate, or subangular with rounded lateral edges, variable in size. The surface is covered with raised microscopic dots and covered only with a thin dermis that does not conceal them.

The adambulacral plates are small; each has a regular furrow comb of three slender webbed spines, directed horizontally. On the actinal face, and separated from the inner ones by a naked groove, are two or three, usually two, larger divergent spines, standing transversely to the groove.

The adoral and epioral spines are similar to the ordinary adambulacrals, but rather larger and longer; the perorals are somewhat stouter and blunt.

This was dredged by the Albatross, off West Florida, at stations 2334 (No. 10,190, Nat. Mus., type) 67 fathoms; 2324, No. 10,129, 23 fathoms; 2333, No. 10,179, 169 fathoms; 2323, No. 18,484, in 163 fathoms. Also Bahamas, station 2649, No. 18,474, in 36 fathoms.

Young. The smallest specimen seen $($ No. 18,474) has the radii $4^{\mathrm{mm}}$ and $6.5^{\mathrm{mm}}$. Marginal plates seven in each row.

The dorsal plates are arranged nearly as in the type, but the specimen is preserved in better shape and all parts are neatly regular.

The plates are not only much smaller, but lie flatter and their outlines are less distinct because the dermis is a little thicker, most of the plates bear one small sharp spinule, situated on the 
inner edge, just over the papular pore, or between them when there are two pores.

The median radial row of plates is less compressed proximally than in the type, and less depressed, being nearly on the same level as those adjacent, but the plates have the same form, and distally near the ends of the rays they become flat, polygonal, and have no pores between them, as in the type; most of them bear a single median sharp spinule on the inner edge. There are three radial rows of plates on each side of a ray, the outer one of about three plates. Papulæ form two rows on each side of a ray, with a few in a third row. The five primary radial and five interradial plates are larger, thicker and more distinct than the rest, but are not turned up, as in the type, and they bear very few minute spinules. They surround a central area of small plates covered with dermis and bearing isolated spinules. A minute dorsal pore is present, surrounded by microscopic spinules; marginal plates are essentially as in the type, but all parts are much smaller, and the upper ones mostly bear but one minute spinule. The comb of marginal spinules and the inferomarginal plates are largely webbed and the spines are very slender.

Interactinal plates form two chevrons with a few of a third, most of them have two small webbed spines on the aboral end.

Adambulacral spines are like those of the type, but much smaller.

Other specimens are intermediate in size between the above and the type, and have intermediate conditions, as to plates and spinules, but all agree so closely that their identification is easy.

Poraniella echinulata (Perrier) Verrill, 1914c.

Marginaster echinulatus Perrier, Bull. Mus. Comp. Zoöl., ix p. 17, 1881;

Etoiles de Mer, p. 230, pl. i, figs. 6, 7 ; Exped. Trav. et Talism., p. 169, 1894, (redescribed). Sladen, Voy. Chall., xxx, 366, 1889.

Poraniella echinulata Verrill, Annals and Mag. Nat. History, vol. xiv, p. 20, July, $1914 c$.

Radii of the type are $3^{\mathrm{mm}}$ and $5^{\mathrm{mm}}$; ratio $1: 1.66$. The form is somewhat stellate. According to Perrier (1894) the type has the following characters :

On the dorsal side the central plate is surrounded by ten plates, five larger basals (interradials), and five radials, the last two 
sets are in contact. The radials are pentagonal. In this central area are no papular pores, but a large one stands next to the suture between the radials and basals.

The carinal row, beyond the basal, has five pentagonal plates. The proximal lobe overlaps the edge of the preceding plate, and has a papular pore each side of it. The other dorsal plates, similar in form, are in oblique short rows that run from the carinal to the marginal plates; the first row has three plates; the second and third two plates each.

There are isolated papular pores each side of the plates of the first row, forming four radial rows of pores. There are also two rows of small interradial plates.

The dorsal plates mostly bear from one to three small spines. No pedicellariæ were found.

The superomarginal plates are four to each side of a ray; they are longer than wide, destitute of a marginal row of spinules, but bear small scattered spinules. The ocular plate is rather large, ovate, unarmed. The inferomarginals are five to each side of a ray. They are longer than wide and each bears a row of five to seven marginal spinules, which are short and divergent, forming a marginal fringe. The distal plates are very small.

The few interactinal plates form two chevrons. The first has no impaired interradial, each of its halves has five plates adjoining the adambulacrals and larger than the latter, so that one corresponds to two adambulacrals.

The second chevron has an impaired interradial plate, and each half has two plates; a second odd interradial lies opposite the median suture of the inferomarginals. These plates are not imbricated and each usually bears two small central spinules.

The adambulacral plates project into the groove and the inner edge bears a divergent row of three to five small spinules; on the actinal side they bear a somewhat oblique transverse row of two or three somewhat larger spinules.

The jaws are elongated, each half bears a large terminal or peroral spine and a row of four smaller graded adorals; also one enlarged epioral, inclined toward the mouth.

Blake Station 278, in 69 fathoms, off Barbados (3 specimens.)

This species seems to be nearest Poraniella, but the cotypes, which I have examined, are all evidently very young. Thus the 
adult might be a Porania or some other related genus. I have seen only one type. It differs from the other similar small or young forms, in having more spines in the furrow-comb, as in Poraniella.

From $P$. regularis it differs especially in the form and arrangement of the dorsal plates. In the latter they are more numerous and show no tendency to form oblique rows running from the radials to the marginals, nor are the radial plates pentagonal, for their exposed edges are meniscoid or pelecoid. For the present, or until larger specimens can be found, I prefer to place this species under Poraniella, on account of its having the same arrangement of adambulacral spines and interactinal plates and spinules.

Genus Marginaster Perrier. (Type. M. pectinatus).

Marginaster Perrier, Bull. Mus. Comp. Zoöl., ix, p. 16, 1881; Etoiles de

Mer, p. 229, 1884. Sladen, Voy. Chall., xxx, p. 364, 1889. Perrier,

Exp. Trav. et Talism., p. 164, 1874.

Form pentagonal or stellate with short rays. Disk and rays a little convex, edges thin, bordered by a fringe of marginal spinules. Dorsal plates well developed, flatish, imbricated, covered with a thin integument, which often partially conceals the plates in alcoholic specimens; median radial row distinct. The larger plates usually bear few small spinules, often only one or two to a plate. Papulæ few isolated between the plates.

Upper and lower marginal plates distinct, about equal in number; the lower ones are larger and more prominent, and bear a terminal row of several spinules, forming a marginal fringe. Upper ones have fewer and smaller spinules, in a row in the type. Papular pores do not occur between the two rows of plates, in the type, but are present in some of the related species.

Interactinal plates few, rather flatish, imbricated or tesselated, arranged in short rows or chevrons, usually bearing one to three small clustered spinules. One or two plates are impaired between the jaws and the median interradial suture.

The adambulacral spines are small and in typical species form a short, transverse, usually oblique row of two to five spines; the two inner ones often stand nearly side by side. Jaw-plates relatively large, convex, separated by a median groove, and bor- 
dered by a regular lateral row of several spines, and a pair of larger peroral spines.

Papular pores occur mostly singly over most of the dorsal surface of the rays and disk, and sometimes between the marginal plates. In $\boldsymbol{M}$. pectinatus, the type, they are few and confined to the rays.

When first established by Perrier this genus included two very small unlike species ( $M$. pectinatus and $M$. echinulatus) from the West Indies. The former should be the type. These were both incorrectly figured. Later (op cit., 1894) Perrier redescribed them in detail, and added a third. They are quite unlike, as shown by the original types, which I have examined, and may represent two diverse genera, owing to the different character of the adambulacral armature, for in the second species there is an inner longitudinal fan of three webbed spinules on each plate.

As in Rhegaster they may both be the young of other genera, such as Porania, etc. I have studied a considerable series of these and allied species, but they are all small and probably mostly quite immature. Therefore, the status of the type of the genus seems to me rather uncertain.

At present, it seems best to restrict the genus to those species, which, like the type, have a simple transverse row of adambulacral spines. Those that have an inner longtitudinal comb should be referred to Poraniella, or to Rhegaster.

\section{Marginaster pectinatus Perrier.}

Marginaster pectinatus Perrier, Bull. Mus. Comp. Zoöl., ix, p. 16, 1881. Nouv. Areh. du Mus., vi, p. 229, pl. i, figs. 4, 5, 1884. Exp. Sci., Trav . et Talism., p. 167,1894 , redescribed. Sladen, Voy. Chall., xxx, p. 366,1889 . Verrill, $1914 c$, p. 18.

The type of this species, which is preserved in alcohol in the Mus. Comp. Zoölogy, has been examined by me.

The adambulacral plates are small and crowded; each bears an inner or furrow-spine and one or two outer ones, there being but one of these distally, while on the middle part of the groove there may be two, or sometimes three spines, forming a small simple transverse row. These spines are all very small, slender, and crowded, most so near the middle of the rays.

The interactinal areas contain about ten to twelve plates, 
which, when moist, are visible through the thin dermis that covers them. A few of them bear one, two, or sometimes three small clustered spinules.

The carinal radial row of plates is rather conspicuous; the plates are larger than those adjacent, irregularly four-lobed, overlapping by their lobes. Small, isolated, short, acute spinules are borne on most of the dorsal plates. The superomarginal plates of which there are six on a side, do not reach the margin; they bear only a few granule-like small spinules, as now preserved.

The inferomarginal plates project strongly beyond the margin; those in the middle of the interradial margin are decidedly larger than the others. The marginal fringe of spines, that they originally bore on each series, was mostly rubbed off before I first saw the specimen, in 1896, but Perrier (1894) states that there were four or five flat, lanceolate spinules on each plate of the lower series. His figure, however (1884), represents them as slender and acute. The figure is incorrect in various other respects.

According to the later description by Perrier (1894, p. 167), the type of this species has the following characters:

Radii $4^{\mathrm{mm}}$ and $5^{\mathrm{mm}}$. The adambulacral plates bear one inner spine and another, or more often two, on the actinal side, a little larger than the inner one, divergent and placed one behind the other in a transverse row.

On the dorsal side the central, five radial, and five interradial plates are distinct. The basal radials are triangular with rounded corners, with the wider end turned proximally. The five carinals are imbricated and slightly cruciform, decreasing regularly distally. The ocular or terminal plate is semicircular and without spines.

The central plate has three spinules: the interradials six or seven; the basal radials three; the carinals two or one.

Transverse rows of smaller elliptical dorsolateral plates run from the carinals to the marginals. The first and second series have apparently, three plates; the third two plates; the fourth and fifth each have one unarmed plate. The larger of these plates bear two or sometimes three, small spines; the smaller only one spine. On the disk there are a few other plates irreg- 
ularly placed. The papulæ are large, all dor'sal, and arranged in rows.

The superomarginal plates correspond with the lower ones; each bears a marginal series of three or four flat, lanceolate spinules.

The inferomarginals are five on each side of a ray. They are rectangular, broader than long; each bears a marginal row of four or five flat, lanceolate, acute, hyaline spinules, forming a marginal fringe of spines.

The jaws are triangular, of moderate size, not prominent. Each half bears an angular peroral spine, four lateral spines, and two or three epiorals.

The interactinal plates form a triangular area; three larger ones stand in an impaired median row, running from the jaws to the median interradial suture; one small plate intervenes between the second interradial marginal plate and the third adambulacral, a larger plate lies between the third marginal and the fifth adambulacral. A series of three plates, the middle one alone well developed, runs from the suture between the first and second, and that of the sixth and seventh adambulacrals; the last plate lies between the sutures of the second and third marginals and that of the eighth and ninth adambulacrals. Some of these plates bear a single spinule; most are without spinules.

Perrier refers to the type specimen as "unique" (1884, p. 230, foot note). He states that it was accidentally irregular, which was the case in the type seen by me. The only locality given was the Blake Station 32 , in 95 fathoms, N. lat. $23^{\circ} 52^{\prime}$.

\section{Porania (?) austera Verrill.}

Marginaster austerus Verrill, Revision Genera Starfishes, Trans. Conn. Acad. Sci., vol. x, p. 221, 1899.

Porania? austera Verrill, Ann. and Mag. Nat. History, vol, xiv, p. 20, $1914 c$.

Plate iii ; figures $1-1 a$. Plate xi f figures $6-6 a$. Details.

Body flat below, swollen above, with short, thick, rapidly tapered acute rays. Radii of the type $11^{\mathrm{mm}}$ and $17^{\mathrm{mm}}$; ratio, $1: 1.6$; marginal spines eleven. Whole surface covered with a rather thick dermis which conceals the outlines of all dorsal plates and most of the ventral ones, except the interactinals. 
The dorsal surface is eovered irregularly with small, short, blunt or clavate rough spines. These stand partly isolated, partly in little irregular rows of two to six. These rows run in various directions, but on the rays mostly obliquely or transversely to the ray, but without order. The concealed plates are irregularly lobed and reticulated, so as to leave rather large isolated papular pores, which are scattered over the whole dorsal surface, and also form a regular row between the two rows of marginal plates, where they are either single or two together. Madreporic plate, which is nearer the center than the margin, is small, oval, with fine gyri, and surrounded by small obtuse spines. Dorsal pore is small, surrounded by very small spinules.

The superomarginal plates are irregularly three-lobed or fourlobed, emarginate on both edges for papular pores. Each one bears about three or four small erect spinules like those around them, and irregularly placed.

Inferomarginal plates are prominent, beyond the upper ones, and form the margin. They have marginal notehes between them. Each bears a horizontally projecting, single, outer marginal row of about five or six elosely placed, slightly divergent, and only a little unequal, oblong, blunt spines. Above these, on the upper side, there is another row, corresponding in number, but not half so long, of small, acute spinules.

The under side of these plates, as seen through the thinner dermis, is transversely oblong, with the lateral margins slightly incurved, and with a small groove and marginal ridge at the inner end; the ridge may end in a slight tubercle at one or both ends. The rest of the surface is covered with minute rounded elevations.

The interactinal plates are casily visible, and mostly without spinules. They form oblique forked rows running from the marginals to the adambulacrals. The rows are separated by spaces covered only by the dermis, but the plates in each row are in close contact or slightly imbricated.

These rows or series of plates start from an angular plate opposite the suture between two inferomarginals. This is joined adorally by two (sometimes one) long-ovate, narrower plates, with the larger end centered; each of these is followed by two 
similar but smaller plates, each of which abuts against two adambulacrals.

The two primary interradial rows start from an impaired plate, in line with the suture between the first marginals. Its two halves diverge rapidly, in a curve, leaving a small, nearly smooth and naked, triangular area outside the jaw-plates. A few irregular small plates are here concealed under the dermis. In the type two to three of the interactinal plates bear a single small blunt central spine, nove have spinules.

The adambulacral plates are concealed by the dermis, which continues upward on the bases of the outer row of spines and forms a short continuous web between them.

Each adambulacral plate bears an inner small furrow-spine, and on the proximal part of the groove, mostly two larger, a little thicker, and somewhat flattened, oblong or slightly clavate blunt spines. Where not too crowded, these stand side by side, but they often stand more or less obliquely, and there may be but one on some plates. Near the distal end of the groove, they become more slender and more oblique, due to crowding. Near the jaw-plates a few plates may have two inner spines.

The adoral and peroral spines of the jaws are similar to those of the adambulacral plates, but slightly stouter, especially the apical ones. West Indies, special locality not known. (Coll. A. E. Verrill). Also taken by the Albatross.

This is probably immature, but I am unable to refer it to any described species.

\section{Suborder Velata Perrier. (See above). \\ Family Pterasterid æ Perrier.}

Pterasterida Perrier, op. cit., 1875; op. cit., 1884; op. cit. p. 180, 1894. Verrill, op. cit., 1899.

Pterasterida (pars) Sladen, Voy. Challenger, vol. xxx, p. 468, 1889.

Pterasteridee Fisher, op. cit., 1911b, p. 343 Verrill, op. cit., 1914a, p. 266.

This is one of the most peculiar groups of starfishes hitherto discovered. It shows in general characters, a remarkably high degree of specialization not found in any other group. Most of the genera and species are from the deep sea.

Disk usually plump; rays 5-8, usually five, rarerly $6-9$; upper 
surface covered by a supradorsal membrane supported by the tips of long, slender, divergent, often webbed, paxillary spinules and pierced by small concentric pores or "spiracles" often closed and invisible in preserved specimens and usually with a central osculum. Beneath this membrane is a "nidamental cavity" or gonocodium, traversed by the columnar pseudopaxillæ, and containing the papulæ. In this cavity the eggs are retained, and also the young, till they assume the adult form, often 8 to $10^{\mathrm{mm}}$ in diameter. The dorsal skeleton ossicles are lobed or cruciform, loosely reticulated.

The adambulacral spines usually form transverse webbed combs or fans (not much webbed in Hymenasterinæ).

Series of slender, divergent spines more or less appressed and attached to the under surface, or imbedded in it, and usually webbed to the adambulacral fans in Pterasterine, are always present. These peculiar" spines, called "actino-lateral spines" by Sladen, should rather be called retroambulacrals or outer adambulacrals, for they are attached to the outer end of the adambulacral plates. They are sometimes short, and do not reach the margin, except distally, on the rays, but in Pteraster and some other genera their tips usually form the marginal edge of the disk.

Between the bases of these there is usually a small slit or pore (actinal spiracle or "segmental aperture") furnished with a partly calcareous valve. Interactinal plates are lacking. Pedicellariæ have not been found. Jaws have a series of adoral spines, usually webbed. Epioral spines of large size, in one to three pairs, often without webs, stand perpendicular to the jaw; those of one pair are sometimes specialized and partially hyaline. Ambulacral feet are large, in two to four rows, with large apical suckers.

The supradorsal membrane may be thin and translucent, with thin muscular fibres, or thick and muscular. In some cases it contains calcareous spicules, muscular and cartilaginons fibers in the form of a network, and often abundant mucous glands. The copious mucus is phosphorescent in some cases (Diploptereaster.) The intestine and anal pore are well developed. Sexes are alike externally. 


\section{Subfamily Hymenasterinæ.}

The genera Hymenaster, Cryptaster and their allies form a distinct subfamily, Hymenasterince, differing from Pterasterince in lacking webbed combs of adambulacral spines and in other characters. It is a characteristic deep-sea group. One or two species occur in the West Indies in deep water.

\section{Subfamily Pterasterinæ. (See above).}

Genus Pteraster M. and Troseh.

Pteraster Müller and Troschel, Syst. Aster., p. 128, 1842. Type, P. militaris. Sladen, op. cit., p. 470, 1889. Fisher, op. cit., 1911b, p. 344, (Analytical table of all known species, pp. 368-370.) Perrier, op. cit., 1894, p. 181. Clark, op. cit., 1908, p. 286 (Analytical Table.) Verrill, op. cit., $1914 a$, p. 267.

Hexaster Perrier, Comptes-rendus, vol. 112, p. 1227, 1891. Type, H. obscurus Perrier.

Temnaster Verrill, Proc. U. S. Nat. Mus., vol. 17, p. 275, 1894. Type T. hexactis V. $=H$. obscurus $P$.

Disk large; rays 5 to 8 ; ambulacral grooves turn up distally, more or less reaching to the upper side of the rays.

Adambulacral spines form large, webbed combs. Retroambulacral or "actinomarginal" spines are closely appressed, ending in a fringe or fold. One pair of specialized epioral spines; these are often translucent distally. Supradorsal membrane furnished with a central contractile osculum, guarded by five or more groups of webbed, projecting spines. It usually contains irregular muscular or elastic fibers for its support and sometimes calcareous deposits. The muscular bands usually do not form a regular network and are generally very inconspicuous externally. Usually two rows of ambulacral sucker-feet.

Pteraster caribbeus Perrier.

Pteraster militaris A. Agassiz, op. cit. (non Müller.)

Pteraster caribbaus Perrier, op. cit., 1881, p. 13; Etoiles de Mer, p. 216, 1884.

\section{Plate vii; figure 4.}

The radii of the type were $15^{\mathrm{mm}}$ and $30^{\mathrm{mm}}$; ratio, $1: 2$. One before me has them $8^{\mathrm{mm}}$ and $12^{\mathrm{mm}}$. The adambulacral comb of very slender hyaline, webbed spines contains six or seven erect spines, increasing in length outwardly, and another, the retro- 
ambulacral, much larger and longer, recumbent, extending beyond the border of the ray and forming a webbed margin. The dorsal parapaxillæ, as seen below the supradorsal membrane, are mostly cross-shaped or four-lobed at the base, two of the lobes are often longer than the others, and somewhat enlarged distally. These lobes overlap and underlap those of the adjacent plates. From the center arises a very slender and rather long column, longer than the longest basal lobes, and about three or four times higher than thick. It is enlarged or subcapitate at the summit. Each bears about eight to ten long and very slender divergent, hyaline, webbed spinules, which enter and support the supradorsal membrane.

The jaws are prominent, subconical; each half has about six very slender marginal spines, becoming longer adorally.

The specialized epioral spine is relatively large, long, flatish, wider near the tip, or sublanceolate, nearly vitreous or translucent, and subhyaline in its distal half. It reflects prismatic colors in some lights.

The madreporic plate is hemispherical, raised on a stalk about as high as broad. The dorsal membrane is very thin and delicate and rises into many small conical or subacute angular elevations when dry.

This is a delicate and fragile species closely related to P. militaris of northern and arctic seas. Its supradorsal membrane is more delicate and its supporting parapaxillæ are longer and much more slender, with longer and more thread-like spinules.

This species was dredged by the Blake Exped. at four stations off Florida and among the Lesser Antilles, in 151 to 422 fathoms.

The Aibatross dredged it at. Station 2667, off Sonthern Georgia, N. lat. $30^{\circ} 53^{\prime}$, in 273 fathoms (No. 18,415, described above.) It was not obtained by the Bahama Expedition.

\section{Order Phanerozona Sladen (emended).}

Phanerozona (emended) Sladen, Voyage Challenger, Zoöl., rol. xxx, Introd. pp. xxviii, xli, 1889. Verrill, Revision, Trans. Conn. Acad., x, p. 200, 1899. Fisher, op. cit., 1911b, p. 17. Verrill, op. cit., $1914 a$, p. 280.

Valvatce + Paxillosce (as orders), Perrier, in Mem. Etoiles de Mer, Antilles, ete., p. 154, 1884.

Valvata + Paxillosa Perrier, Exped. Trav. et Talism., $\mu \mathrm{p} .22,23,29,29$, 1894; Resultats Camp. Scientif., Albert I, fase. xi, p. 16, 1896. 
This order includes starfishes varying in form from pentagonal to stellate, with long rays. They have two rows of large and thick marginal plates (rarely but one distinct row, as in Luidia), which are usually in contact and form a thick, nearly perpendicular margin. They are nearly always larger and thicker than the dorsal and actinal plates. Papular pores are nearly always confined to the upper surface and are usually placed singly, often in special areas. Dorsal skeleton various. The dorsal surface may be closely covered with angular tesselated plates, which may be naked, granulated, or covered with a smooth skin, or they may take the form of pseudopaxillæ, protopaxillæ or true paxillæ especially in the Paxillosa.

The various forms of paxilliform plates as distinguished in 1894, by the writer, are as follows :

True paxilla are columnar or hour-glass-shaped ossicles, usually with isolated, circular or lobed bases, which bear at summit a group of small spinules, of which the marginal series are different from the rest and divergent, so as to cover the intervening spaces between the spines, thus forming fascioles or channels for the circulation of water to the papulæ. These are highly developed in Astropecten and Luidia. Those called spinopaxillo are of the same general structure, but the center of the summit is occupied by a distinct spine, or by more than one. Such forms occur on some species of Luidia, Pontaster, etc.

Parapaxillce are rounded or stellate ossicles, or angular plates, with a raised central portion, tabulate, truncate, or like a low cone. They may be either isolated or articulated by their bases. The summit is covered with small, differentiated spinules, like those of true paxillæ. Those on the dorsal surface of Lophaster, Solaster, and Mediaster are examples. They sometimes bear a central spine.

Protopaxilla are similar, but less elevated, convex ossicles or plates, covered with round or angular granules, with the marginal series differentiated and more or less covering the grooves between the plates. As in the preceding, there may be a central spine in some cases. This form occurs on Cheiraster, many species of Goniasterida, etc. The transition from this last kind to simple, uniformly granulated plates is easy, when the grooves between the plates become obsolete. 
Pseudopaxilloe are articulated plates with flattened, usually lobed, and often overlapping bases, which bear a group of slender, fascicled or divergent spinules on the more or less raised central or subcentral area or boss. These have no differentiated marginal series of spinules. This form is seen in Henricia, ete.

In some families the plates are reticulated ossicles, smooth or bearing large spines or tubercles as in Oreasteridce. In other cases a thick skin may cover and obscure the plates.

The interactinal plates may be few in slender stellate forms or many in the pentagonal forms. In the latter cases they are usually arranged in definite rows, most often subparallel with the adambulacral plates, the latest formed ones being situated next the median, interradial, marginal plates, but they also form rows running from the adambulacral plates to the marginals; and often define fasciolated grooves.

They are most commonly tesselated and granulated, or else in the form of pseudopaxillæ or protopaxillæ; but they are sometimes spinose. They may be more or less imbricated by their edges or lobes.

Adambulacral plates are not compressed, rather large, usually oblong or quadrangular, and commonly bear numerous small spines, various in arrangement.

Ambulacral plates are rather large, not compressed nor crowded. Ambulacral feet are in two rows, with terminal suckers in Valvulosa; but in the Paxillosa they are large and pointed, without distinet suckers.

Pedicellariæ are sometimes lacking, but usually present and sometimes large. They may be bivalved, sessile, and seated over a pore (foraminate), or implanted in special pits on the plates (fossate); or else papilliform or fasciculate, composed of two to four or more modified, convergent spinules; or pectinate, consisting of two comb-like groups of spinules convergent over a suture between two adjacent plates, as in Luidiaster, or seated on a single plate.

The sessile valvular pedicellariæ with a pore between the valves are called foraminate; they may have two, or more than two, valves (bivalvular and trivalvular, ete.). In the suborder Valvulosa they are often provided with a pair of pits or fossæe, into which the valves fit when widely open. The valves in these 
are often spatulate, spoon-shaped, or suger-tongs shaped, or battledore-shaped, and usually may best be called plataleiform or spatulate. When furnished with receiving pits, they have been called excavate; but fossate seems to be a more appropriate term.

The peculiar papilliform pedicellariæ of the Paxillosa, with two to four or more slender valves, apparently formed by modified spinules or granules, are also found in certain of the Valvulosa. Sometimes such pedicellariæ are found associated with larger valvular pedicellariæ on the same specimen, as in the genus Nymphaster, and in a few other genera.

The following is the arrangement of the suborders and families adopted by the writer (op. cit., 1914a) :

\section{Order PHANEROZONA.}

Suborder I. Valvulosa Verrill = Valvata Perrier. (Sense extended.)

Family I. Ophidiasterdo Verrill, $1867=$ Linckiade Perrier, 1875.

Family II. ValvasterIde Fisher, 1911.

Family III. Asteropide Fisher, $1911=$ GyMnateride (pars) of authors.

Family IV. Oreasteride Fisher = Pentacerotidce Gray (restricted).

Family V. Mimasterid

Family VI. Goniasteride Forbes (restricted), includes $A n$ theneida Perrier (restricted).

Family VII. Odontasterid $\approx$ Verrill = Gnathasterince Perrier (pars).

Family VIII. ChæTasteride Ludwig.

Family IX. Archasterida Ver. (restricted to Archaster).

Suborder II. Nотомхота Ludwig (as an order).

Family X. BеNтhopectinide Verrill; Benthopectinince Verrill, 1894.

Suborder III. Paxillosa Perrier (sense restricted).

Family XI. Porcellanasteride Sladen.

Family XII. Goniopectinide Verrill.

Family XIII. Astropectinides Gray (restricted).

Family XIV. LuIDIID $\&$ Verrill = Luidiince Sladen. 
All these families, except Nos. ii, iii, v, and ix are represented in the West Indian area, but some of them occur only in deep water.

Subfamilies of GonIaSTERD开.

Subfamily I. Goniasterinæ Verrill = Pentagonasterince Sladen (pars).

Subfamily II. Pseudarchasterine Sladen.

Subfamily III. Medinsterine Verrill.

Subfamily IV. Nectrinne Per.; Fisher.

Subfamily V. Hippasterina Verrill.

Subfamily VI. Antheneinæ Fisher (sense restricted).

Subfamily VII. Leptogonasterine Perrier.

Subfamily VIII. Chitonasterin

Those subfamilies represented in the West Indian shallowwater fauna are the first, third and seventh. But the seventh is essentially a deep-sea group; only a few stray examples occurring in less than $\mathbf{1 5 0}$ fathoms. The third and fifth families are well represented in the deeper waters. The others are chiefly extralimital.

\section{Suborder VaLvulosa Verrill.}

Valvulatce (order) Perrier, Nonv. Arch. Mus. Hist. Nat., vi, 1885.

Valvata (order) Perrier, Exped. Trav. et Talism., pp. 22, 23, 28, 29, 1894.

Valvata (suborder) Verrill, Revision, Trans. Conn. Acad., $\mathbf{x}$, p. 200, 1899.

Valvulosa Verrill, North Pacific Starfishes, p. 284, 1914a.

These starfishes are stellate or pentagonal and usually rather stiff in appearance, and are nearly always five-rayed. The dorsal plates are most commonly tesselated and granulated, or else take on the character of protopaxillæ or pseudopaxillæ. Owing to the generally close union of the plates, especially of the large marginal plates, most of these starfishes are rather rigid, showing much less flexibility than in most other groups. The Ophidiasteridce are exceptional in this respect, for they are mostly flexible in life.

Ambulacral feet are large, with well developed suckers.

Pedicellariæ are often lacking; when present they are usually valvular, foraminate and sessile, or fossate. The valves may be either granuliform, or large and broad, or narrow and spoon- 
shaped, plataleiform, spatulate, or battledore-shaped, rarely papilliform. There may be two to five valves. The valvular form of the pedicellariæ first led to the establishment of this group.

The various kinds of dorsal plates pass into each other by various intermediate forms, so that it is impossible to draw any very strong or sharp family lines on this character alone, though the character of the plating may generally be taken as of generic value. They are more frequently polygonal and tesselated; often in the form of protopaxillæ or parapaxillæ; sometimes deeply lobed and openly reticulated; sometimes imbricated.

Sometimes they are naked; often spinose; very rarely truly paxilliform; sometimes covered by a thick, smooth, or granulated integument.

Both rows of marginal plates are usually well developed and form a stout margin to the disk and rays.

Interactinal plates are usually rather numerous and tesselated or imbricated. A distinct dorsal pore is usually present. Genital pores are generally ten, usually all separate, situated in the dorsal interradial areas; sometimes serial on the sides of the rays.

Superambulacral plates are present in some genera, absent in others. The existence of superambulacral plates, formerly supposed to be characteristic of Astropectinida, occurs in several of the genera now referred to Valvulosa (viz., Mediaster, Dytaster, Pseudarchaster, etc.), and in other groups.

Adambulacral plates wide, with a longitudinal group of small furrow-spines and with one or several spines on the actinal side, often becoming much longer distally. Jaw-plates are large and usually convex on the actinal surface, bearing numerous oral and epioral spines.

This is a very extensive group, found in all seas.

\section{Family Ophidiasteride Verrill.}

Ophidiasterida Verrill, Trans. Conn. Acad. Sci., i, part 2, p. 344, 1867; op. eit., p. 308, 1914a.

Linckiadce Perrier, Revision Stellerides, p. 117 [381], 1875.

Linckiidce Sladen (pars), op. cit., 1889, p. 397. Fisher, op. cit., 1911b, p. 240.

Linckiadk Viguier, Squelette des Stell., p. 144, pl. ix, figs. 1-13; pl. x, figs. 1-7, 14-19 (structure), 1879. 
Form stellate, usually with five slender, flexible rays, but the number is variable in some autotomous species.

Abactinal and marginal plates usually tesselated or subimbricated, in rows or irregular; in most cases granulose (covered with rather thick, smooth skin in Leiaster), sometimes tuberculated, rarely spinose.

Marginal plates are usually well developed, in two regular rows, but often not conspicuous and rarely so thickened as to form a rigid margin. They are similar to the dorsal plates, as to granulation.

Papulæ usually numerous, mostly abactinal and lateral and in groups, sometimes single; in some of the genera they occur also between or below the marginals, or between the interactinal plates.

Adambulacral plates small, covered with either granules or spinules, the margin bearing one or two rows of small spines, no more.

Pedicellariæ often lacking; when present, usually bivalve, sometimes spatulate and fossate. Superambulacral plates often present.

\section{Genus Ophidiaster Agassiz (restricted).}

Ophiaiaster '(pars) L. Agassiz, Prod. Monog., 1834. Gray, op. cit., 1840, p. 283; Synopsis, 1866. Müll. and Trosch. (pars), Syst., p. 28, 1842. ophidiaster (emended) Lütken, op. cit., p. 163, 1864. Perrier, Revision, p. 384,1875 ; op. cit., 1884, p. 221 (descr.)

Linchia (pars) Nardo, 1834. Von Martens, op. cit., p. 351, 1865.

Disk small; rays slender, subterete, closely granulated. The dorsal plates are in about three to five regular rows, leaving squarish or angular papular areas between them in regular rows. Papular areas sometimes occur, also, between the marginal rows; rarely, also, in one submarginal row. The marginal plates, which form two regular rows, are not unlike the dorsals, and closely granulated. Interactinals are smaller, angular, and usually form one or two narrow rows. Adambulacral plates usually have two unequal small spines on the inner edge, and one just back of them in the second series decidedly larger, stout, but not much elongated. Superambulacrals are usually present but small. Fossate pedicellarix, usually with spatulate valves, occur on most species. 


\section{Ophidiaster guildingit Gray.}

Ophidiaster guildingii Gray, op. cit., 1840, p. 284; Synopsis, p. 13, 1866 (description inadequate). Perrier, Revision, p. 387, 1875 (no description). Luïtken, op. eit., 1871.

Scytaster mülleri Duchassaing, Ann. Rad. des Antilles, 1850 (t. Perrier from types.)

Ophidiaster flaccidus Lütken, Vidensk, Meddel., p. 86, 1859 (good description.)

Rays five, with a weak skeleton, roundish, slender. Radii of a medium sized specimen $5^{\mathrm{mm}}$ and $60^{\mathrm{mm}}$; ratio $1: 12$. Other specimens have shorter rays. The dorsal and lateral surfaces are covered with about nine rows of plates, between which there are eight equally spaced and pretty regular rows of large papular areas, each with about five to twelve papular pores. There is no median area destitute of papule. Marginal plates are much like the dorsals. All these plates are covered with small, unequal, squammiform granules, some of them minute.

The adambulacral plates bear two rows of small obtuse spinules; those of the inner or furrow series are small, equal, and crowded; those in the adjacent outer row are decidedly larger, about half as numerous, with some granules between their bases.

The color, in life, commonly varies from orange-red, with irregular yellow markings, to purplish brown, with blotches of dirty white (Clark).

Lütken (op. cit., 1871) recognized that his 0 . flaccidus is the same as $O$. guildingii Gray.

Locality of Gray's types was unknown. Perrier, who examined the types, states that they are identical with $O$. flaccidus.

St. Thomas (Lütken; Perrier). Fort Reef, Port Antonio, Jamaica (Clark.)

\section{Ophidiaster Florid E Perrier.}

Ophidiaster floriada Perrier, op. eit., 1881, p. 9; Mem. Etoiles de Mer, p. 221, pl, iv, fig. 1.

This was described from a single young specimen (radii 5 and $33^{\mathrm{mm}}$ ) from off Florida, in 201/2 fathoms.

It is, perhaps, the young of $O$. guildingii, the common shallow water West Indian species.

According to Perrier it is formed much like a Linckia. The dorsal and marginal plates form seven regular rows of elongated 
oval plates, covered with a granulation much like that of the actinal side. The plates are rather prominent and distinct.

No papulæ are found below the inferomarginal plates; between the marginal and dorsal rows there are six regular rows of papular areas, each having two to four pores.

The disk has ten distinct radial and interradial plates.

Interactinal plates are smaller than the marginals, arranged in few regular rows, without papulæ between them, but defined by the rather large rounded granules that closely and regularly cover them.

The adambulacral plates bear two contiguous rows of spines; those of the inner marginal row are small, regular, and equal; in the outer row each group has a much larger, obtuse median spine and a small flat one each side of it.

On the interradial areas are two rows of interactinal plates that bear spines similar to those of the outer adambulacral spines but smaller; some of them bear fossate pedicellariæ, having spatulate valves. The second row is, however, in the young specimen, feebly developed with few plates.

Straits of Florida, in 123 feet (Perrier, Coll. Mus. Comp. Zoöl.). Probably 123 fathoms was intended. Off E. Florida, 277 fathoms, Albatross collection.

OpHidiaster aLEXandRi Verrill, sp. nov.

Plate xiii ; figures $3,3 a, 3 b$. Details. Plate xxv; figure 2. Type.

Disk small, rays regularly tapered, subacute. Radii of the type $11^{\mathrm{mm}}$ and $60^{\mathrm{mm}}$; ratio, $1: 5.5$. The upper and lateral surfaces of the rays have five very regular and nearly equal rows of somewhat prominent plates, closely united radially, but so openly and regularly united transversely as to leave nearly square papular areas, which form very regular rows. They contain about eight to ten pores.

The disk is somewhat convex. It has a set of basal radial and interradial plates, and a central, larger than those of the rays, and a little swollen.

The madreporic plate is large, round, flat, covered with fine radiating gyri. The whole surface of the plates and the papular areas is covered with a fine even granulation, above and below. 
The interactinal rows of plates, beneath, are so closely united and densely granulated that their outlines are not visible without preparation. When denuded they are seen to form three rows. The three plates in a transverse series are imbricated. These plates are ovate, except the one next to the adambulacral plate, which is truncated at the suture, and corresponds in width and position to the adambulacral that it joins. Two transverse series correspond to one inferomarginal. The latter are much larger and four-lobed.

The small transversely oblong adambulacral plates are finely granulated and bear a simple row of very small and short, flat, blunt marginal spinelets, two to a plate; and an outer row of much larger and longer, stout, tapered spines, alternating with very small acute spinelets, one of each kind on each plate.

Dredged by the Bahama Expedition at stations 56 and 57 on the Pourtales Plateau, off Florida, in 200 to 225 fathoms. Taken by the Albatross at station 2416 in 276 fathoms, coral sand and shells, N. lat. $31^{\circ} 26^{\prime}$, off Georgia, several specimens. (Nat. Mus.; Yale Mus.)

Perrier (1884, p. 172, and 1894, p. 37) listed an undescribed species of this family as "Fromia mexicana" from station 207, off Martinique, in 96 fathoms. This seems not to have ever been described, and is to be regarded as a MSS. name.

\section{Genus Linckia Nardo.}

Linckia Nardo, Okens Isis, 1834, p. 717. Gray, op. cit., 1840, p. 284; Synopsis, p. 13, 1866. Lütken, Vidensk. Meddel., pp. 163, 164, 1864 (emended); op. cit., p. 266, 1871. Viguier, Arch. Zoöl. Exper. et Gen., vol. vii, p. 147, pl. x, figs. 1-6 (strncture), 1878. Verrill, op. cit., 1867, p 285; op. cit., p. 309 1914a. Perrier, op. cit., p. 399, 1875; Etoiles des Mer, p. 226, 1884. Sladen, op. cit., vol. xxx, p. 408, 1889. Fisher, 1911b, p. 242.

Ophidiaster (pars) Müller and Troschel, Syst. Ast., p. 28, 1842.

Disk small ; rays long, slender, nearly terete, usually five, variable in number in some autotomous species. Adambulacral plates bear granule-like structures, in two or three close series, those in the second row alternately larger. Pedicellariæ not observed. Two madreporites in autotomous species.

Interactinal plates usually form two or more close rows. Dorsal plates are irregularly arranged, not forming definite 
radial rows; closely granulated. Papulie are numerous, in clusters on the dorsal side, but are lacking below the marginal plates.

\section{Linckia nodosa Perrier.}

Linckia nodosa Perrier, Revision, p. 417, 1875; Etoiles des Mer, p. 226, 1884. Sladen, Voy. Chall., pp. 409, 786, 1889. Fisher, op. cit., 1906, p. 1088.

Plate xiii; figures $2-2 a$. Plate xxix; figures $1 a, 1 b$.

The type of this species had the radii $11^{\mathrm{mm}}$ and $91^{\mathrm{mm}}$; ratio, $1: 8.3$.

The dorsal plates form about three irregular crowded rows; some of these plates, irregularly disposed, are larger and more convex than the others, or even subnodose; similar swollen plates also occur upon the disk.

The papular areas are small and well defined; they mostly have six to eight pores; fewer on the disk. Madreporic plate large, flat, with numerous fine, sinuous gyri.

The marginal plates are squarish, covered with granules a little smaller than those of the interactinal plates; between the two rows are roundisl papular areas, with about twelve pores.

There are several rows of interactinal plates proximally, the inner ones short; the outer or peractinal row extends nearly or quite to the tip of the rays. These plates are all covered with small rounded granules, those near the adambulacral plates are a little the larger.

The adambulacral spines are almost granuliform; they form two rows; those of the margin of the groove are alternately larger and smaller; the larger are clavate, the smaller cylindric. Close to these are the spines of the outer row; each of these is opposite one of the smaller spines of the inner row; they are rather larger than the larger of the inner row. External to these spines is a row of granules larger than those of adjacent plates and also some intermediate small granules. There are no actinal papular pores.

A larger specimen before me was taken by the Albatross off Pensacola, Fla. The radii are $13^{\mathrm{mm}}$ and $125^{\mathrm{mm}}$; ratio, $1: 9.6$.

The rays are well rounded above, flattened below, and taper very gradually. 
The dorsal surface of the rays is covered with a broad, very irregular band of large, swollen, evenly convex, unequal, roundish plates, mostly in contact radially to a variable extent. These, where most regular, seem referable to three rows, by reason of the large, irregular papular areas between them. The plates that seem to belong to the median row average larger and more prominent than the others, but are unequal and seem to be crowded out of position by the growth of others.

Outside of those described, and on the sides of the ray, there is a much more regular row of dorsolateral plates, which are also roundish and strongly convex, but less so than those above. They are in serial contact, but are joined to the row above by small connective ossicles and large intervening papular areas, which form here a regular row. The papulæ are small and very numerous in these and the dorsal groups. Twenty to thirty or more can be counted.

All these plates, as well as those below, are covered closely with small, nearly uniform rounded granules, which also surround the papular pores, but there become angular, so that four or five around each pore look like small valves.

The two rows of marginal plates are very distinct and nearly equal and regular. Their plates are less convex and not so large, about five corresponding to four in the row above. They are broadly in contact serially, but the two rows are separated by a regular row of large papular areas, like those above.

Below the inferomarginals and closely joined to them and to each other there are three or four rows of squarish interactinal plates, so closely united and compactly granulated that their outlines are concealed. Their granules gradually become coarser and angular near the adambulacral spines.

The adambulacral plates are small and concealed by granules. Each bears two unequal inner erect spines; both are flattened and obtuse. The larger is more than twice as large as the other, but only a little higher. Outside these, but close to them, and alternating with them, is a single larger, obtuse, flattened, erect spine, about twice as large as the larger inner ones, and about as broad as high. These, like the inner ones, form a regular continuous row, very distinct from the adjacent granules.

These rows continue to the jaw plates with but slight change, 
but three or four of the most proximal ones of the outer row, and especially the first, become larger, higher and more obtuse, and stand a little farther back from the inner row, the first pair becoming the epioral spines on the small jaws. The inner spines on these few proximal plates also become a little more elongated. About eight somewhat more slender spines in a continuous row, form the peroral armature of the angle of the combined jaw plates.

The granules in the adoral area are larger and higher than elsewhere.

The ocular plate is small, roundish or broad-ovate, convex or mammiform, not bilobed and not granulated. It is turned upward.

The madreporic plate is large, situated below the basal interradial plate and nearly fills the space between two large basal radials, one of which it joins. It is covered with very numerous fine, even, radiating and bifurcating gyri.

The disk is covered with a group of large, unequal, very convex rounded plates, like the radial plates adjacent. Ten of the larger of these can be referred to the basal radial and interradial plates. These enclose an irregular group of about five larger and several smaller plates. The diameter of the larger plates is about $4^{\mathrm{mm}}$; of the madreporic plate, $5^{\mathrm{mm}}$.

I have also examined a young specimen in the Museum of Comparative Zoölogy, labeled as this species by Perrier, and taken by the Blake, at station 100, off Moro Light, Cuba, in 250400 fathoms.

This agrees well with larger specimens, of medium size, taken near the same place by the Bahama Expedition, but its adambulacral spines are relately smaller, and less differentiated from the adjacent coarser granules. The granules of the inferomarginal plates are more unequal, there being two or three rows of distinctly larger ones on the otherwise evenly granulated surface.

These characters seem to be due to the immaturity of this specimen. The dorsal plates are also relately less swollen than in the larger examples.

It was dredged by the Albatross, in 130 fathoms, off West Florida, and in 21 fathoms, off Pensacola (large specimen de- 
scribed above); also, by the Blake, off Moro Light, in 250-400 fathoms; off Tortuga I., Antilles, in 6 fathoms.

The Bahama Expedition took it at station 3, off Havana, in 110 fathoms. The locality of the type was not known. According to Bell, it also occurs in Torres Strait. Probably this is an error.

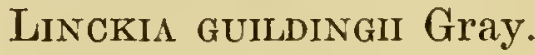

Linckia guildingii Gray, Ann. and Mag. Nat. Hist., vol. vi, p. 285, 1840; Synopsis, p. 14, 1866. Perrier, Revision, op. cit., vol. iv, p. 408, 1875. Sladen, op. eit., p. 410, 1889. A. Agassiz, North Amer. Starfishes, p. 105, pl. xiv, figs. 1-6, 1877. (Details of structure.) Verrill, Trans. Conn. Acad., vol. xi, p. 36, 1901; vol. xii, p. 281, pl. xxxiv, c, fig., 1907; (In The Bermuda Islands, Part v, p. 281 (325), 1901. R. Rathbun, Brazilian Echinod., p. 148, 1879.

Ophidiaster ornithopus Müll. and Troschel, Syst. Aster., p. 31, 1842 (t. Perrier from types). Lütken, op. cit., p. 80, 1859. Duj. et Hupé, op. cit., p. 361, 1862.

Linckia ornithopus Verrill, Geog. Distribution Echinod., Trans. Conn. Acad. Sci., vol. i, p. 344, 1867 ; op. cit., vol. i, p. 367, 1868.

Linckia ornithopus Lütken, op. cit., p. 80, 1859; pp. 266, 270, 271, 1871. Scytaster stella Duch., op. cit., p. 4, 1850 (t. Perrier from type.)

\section{Plate xxviii; figure 3.}

The rays are long, slender, well rounded in life. They are often unequal and vary in number; most frequently they are five or six, sometimes four or seven, due to autotomous division. The dorsal plates in this species are numerous, thick, somewhat convex, irregularly polygonal, and closely crowded, often overlapping by their edges, mostly without connective ossicles, except very small ones laterally. They are like all the rest of the plates, above and below, thickly covered with fine granules. The papular areas between them are small, with few papulæ.

The marginal plates are rather larger than the dorsals, more quadrangular, and form two nearly equal, regular rows.

There are usually, in adults, at least two long regular rows and some shorter ones of much smaller, squarish interactinal plates, and also a small triangular interradial group. These are covered and obseured by the crowded granulation.

Adambulacral plates bear two rows of small, short spinules, and there is also, especially proximally, a row of similar spines 
on the adjacent series of interambulacral plates, parallel to the outer row, so that they resemble a third row of interambulacral spines. These interactinal spines agree in number and stand opposite to the outer interambulacral spines.

There are usually two madreporic plates in those specimens that divide by autotomy. Specimens with any number of rays from one to five are to be found. Those in the "comet-form," due to autotomy or injury, are not uncommon.

The types of $O$. ornithopus (M. and Tr.) were from Vera Cruz; those of S. stella were from Guadeloupe.

Perrier (1875) stated that he had examined these types and found them identical with $L$. guildingii, as well as with authentic specimens from the Cape Verde Islands. Gray's type was from St. Vincent Island.

On the American side this species occurs at the Bermudas, Florida Keys, Bahamas, Vera Cruz, throughout the West Indies, and south to Bahia, Pernambuco, and the Abrolhos Reefs, Brazil. Cape Verde Islands (Perrier and others). The Yale Museum has it from Pernambuco, Brazil (coll. C. F. Hartt, No. 4557), and the comet form from the Abrolhos Reefs (coll. Hartt, No. 1583).

\section{Genus Narcissia Gray.}

Narcissía Gray. op. cit., p. 287, 1840; p. 15, 1866. Sladen, op. cit., pp. 398, 413, 1859. Perrier, Exped. Trav. et Talisman, pp. 329, 330, 1894.

Ophidiasteridæ with serially arranged radial plates, the median and two marginal rows larger; all granulated. Papulæ stand singly or in pairs between the plates. Adambulacral plates have three longitudinal series of short, thick spines, often prismatic.

\section{NARCISSIA TRIGONARIA Sladen.}

Narcissia trigonaria Sladen, op. cit., p. 414, pl. lxv, figs. 5-8, 1889.

Rays rather long, triquetral, with a strong median radial keel composed of large, somewhat swollen plates; margins rounded with well developed, convex, marginal plates in both series, about thirty-seven in the type. All the plates are covered with minute, uniform granules. Papulix stand singly between the plates, or in pairs. 
The adambulacral plates have three series of short, thick, subprismatie spines, about four in each series, those of the outer one mueh smaller.

Off Bahia, Brazil (Sladen). Specimens from off West Florida, in 25 and 26 fathoms (Nos. 18,454-6, Nat. Mus.) appear to belong to this species.

\section{Family Orensteride Fisher.}

Penlacerotide (pars) Gray, 1840 and 1866. Perrier (pars), 1884, 1894. Sladen, op. cit., 1. 342, 1889 ; and of many other writers.

Goniasteridee (pars) Verrill, 1867. Perrier (pars), 1875.

Oreasteridce Fisher, op. cit., 1911b, p. 18. Verrill, op. cit., p. 282, $1914 a$.

Large phanerozonate starfishes whieh have a large, thick, massive, eushion-like or angulated disk and stout rays. The dorsal areas are large, supported by a retieulated skeleton, leaving large papular areas, containing great numbers of small papular pores, confined to the dorsal surface. The dorsal plates are largely oblong or bar-like, and often have a stellate arrangement. The plates are more or less obscured by a thiek granulose dermis.

The marginal plates are relatively small and ineonspicuous, granulated, and covered by dermis. Like the dorsal plates they may also bear large conical spines.

The interactinal areas are large, covered with thick, tesselated plates, bearing coarse granules, small bivalve pedicellariæ, and often one or more stout eentral spines. Adambulacral plates have a marginal series of spinules, and one or more thiek spines on the aetinal surface.

Besides the genus Oreaster, this family includes Culcita, ${ }^{17}$

17 The arctic starfish described by Süssbach and Breckner (Seeigel. Secst. Schlang. N. und Ostsce, p. 217, pl. i, figs. 4-6, 1910) as Culcita borealis, does not belong to this genus nor to the same family. It seems to be gencrically most nearly related to a large deep-sea form from our northern waters, having a thick dermis and partly aborted dorsal skeleton described by mo as Chondraster grandis (op. cit., 1895, p. 137), formerly as Porania grandis (pars), op. eit., 1878, p. 371.

In this arctic, so-called Culcita, the body is even more swollen and cushion-like, due to a still more rudimentary skeleton, but I see no reasons for separating it from Poraniidx, with which it agrees in other respects. Therefore I have proposed for it a new genus, Culcitopsis, with $C$. borealis for its type. See also Verrill, 1914c, p. 21. 
which is confined to the Indo-Pacific ocean, and several other Pacific genera.

\section{Genus OREnSTER Müller and Troschel.}

Pentaeeros Linck, De Stellis Marinis, p. 21, 1733 (not binomial). Schülze, Betracht. der Verstcin. Seesterne, p. 50, 1760, $t$. Sladen (not binomial). Schröter, Mus. Gottwald. Testac. Stell. mar., cte., P. 58, Nürnberg, 1782, $t$. Sladen (not binomial).

Pentaceros Gray, Ann. and Mag. Nat. Hist., vi, p. 276, 1840. Synopsis, p. 6, 1866. Perrier, Revis. Stell., v, p. 52 [236], 1876. Agassiz, A., North Amer. Starfishes, p. 108, pl. xvi, figs. 1-7 (structure), $187 \pi$. Viguier, Arehiv. Zoöl. Exper. et Gen., vii, p. 193, pl. xi, figs. 4-6, pl. xii, figs. 3, 4, 8-11 (strueture), 1878. Sladen, Voy. Chall., xxx, p. 343 , 1889. Perrier, Exp. Trav. et Talism., p. 406, 1894.

Goniaster (pars) L. Agassiz, Prodr., p. 191, 1835.

Oreaster Müll. and Troschel, Syst. der Aster., p. 44, 1842. Von Martens, Ostasiat. Echinod., p. 81, 1866. Lütken, Vidensk. Meddel., 1859, p. 63 ; op. cit., 1864, p. 161 [39]. Verrill, Trans. Conn. Acad. Sei., i, pp. $278,343,1867$; op. cit., p. 367,1868 . Perrier, Pedicellaires, p. 69, 1869.

This genus includes many large, massive, tropical starfishes, with a large and usually high, swollen, angular disk and rather rigid-looking rays.

The dorsal plates are thick, stellate-reticulated, leaving large papular areas between them, with many small papulæ. The plates are always granulated and some or all often bear large spines or tubercles.

The marginal plates are paired, but not very large, and partly concealed by the thick granulose dermis. The inferomarginals are often confined to the lower side, the superomarginals forming the border. Those of each series may bear stout conical spines or tubercles.

The interactinal plates are numerous on the disk and are usually closely tesselated, bearing granules and conical spines. Strong internal interradial septa containing large calcareous plates support the disk.

The adambulacral plates bear, each, a longitudinal row of two to four or more rather small spines on the inner margin and one or several much larger and thicker spines on the actinal surface.

Pedicellariæ are often numerous, bivalve, usually small, or about equal to the granules among which they are scattered. 


\section{Oreaster Reticulatus (L.) M. and Trosch.}

Asterias reticulata (pars) Linn., Syst. Nat., ed. x, p. 661, 1758. Retzius, op. cit., 1783; Diss., p. 14, 1805. Lamarck, Ann. sans Vert., vol. ii, p. $556,1816$.

Oreaster reticulatus M. and Trosch., Syst. Aster., p. 45, pl. iii, fig. 2, 1842. Pentaceros reticulatus with $P$. grandis and $P$. gibbus Gray, Ann. and Mag., vol. vi, p. 277, 1840, and Synopsis, p. 6, 1866.

Pentaceros reticulatus A. Agassiz, North Amer. Starfishes, p. 108, pl. xvi, figs. 1 to 7 (details of structure), 1877. Viguier, Nouv. Arch. Zoöl. Exper. et Gen., vol. vii, p. 193, pl. xi, figs. 4-6 ; pl. xii, figs. 3, 4 (structure), 1878. Nutting, Narrative Bahama Exp., pp. 52, 187, 202, 212 (colors).

Asterias gigas Linn., Mus. Tessinianum, p. 114, pl. ix, 1753.

Oreaster gigas Lütken, op. cit., p. 64, 1859. Verrill, op. cit., i, p. 367, 1867. R. Rathbun, op. cit., p. 149, 1879.

$O$. lepidosus Grubo and $O$. tuberosus Behm are additional synonyms (t. Lütken). Also A. sebce Blainville. $O$. aculeatus Gray is the young (t. Perrier).

A very large massive species, having a broad, thick or high swollen disk, usually with interradial contractions, in dry specimens, corresponding to the attachment of the stout calcareous, internal, interradial septa.

Radii of a fair-sized specimen are $90^{\mathrm{mm}}$ and $200^{\mathrm{mm}}$; ratio, $1: 2.22$. Much larger specimens occur, up to $500^{\mathrm{mm}}$ or more in diameter. Many have shorter rays.

The dorsal plates have a very distinctly stellate-reticulate arrangement. The median radial row is distinct. Their portions imperfectly visible at the surface are narrow and at their nodes there is nearly always a short, stout, conical spine, both on the rays and disk. The median radial ones are a little larger. The whole surface, between the spines, is closely covered with small unequal granules mingled with small bivalve pedicellariæ of similar size. The granules also extend up on the bases of the spines, ending in a definite ring or border of short, angular, flat or truncate granules. All the granules are minutely roughened.

The papular areas are very large, with great numbers of single papulæ.

The upper marginal plates are not large; about 20 to 22 occur on each side of each ray, in mature specimens. They form the margin of the disk, but their outlines are obscured by the thick 
covering of granulose dermis and two to four short, thick, conical spines that each one usually bears. Their granules are rather coarse, unequal, polygonal, and closely packed. Intermingled with the granules are small bivalve pedicellariæ of sizes similar to the adjacent granules.

The inferomarginal plates are similar in size, and are confined to the actinal side, except close to the tips of the rays. They are granulated in the same way as the upper ones, and each usually bears a cluster of three to five or more short conical spines, the larger ones smaller than those of the superomarginals and quite similar to those of the interactinal plates.

The interactinal plates are numerous, forming large areas, extending well out on the rays. They are arranged in simple divergent rows, the first rows subparallel to the adambulacral plates, but also forming single oblique rows, each one corresponding to a single adambulacral plate, but two usually corresponding to a single inferomarginal plate. They and their sutures are covered with large granules and bivalve pedicellariæ coarser than those on the dorsal side, and each usually bears also a central group of two, three, or more, short, stout, blunt, unequal spines.

Their pedicellariæ mostly have an ovate or elliptical basal raised cup, which encloses the basal part of the two wide and short valves. They are larger than those of the dorsal side, with relatively wide valves.

The adambulacral plates have a marginal series, nsually of three or four, small, flat or angular blunt spines, and the actinal side bears one or two short, stout, conical spines, surrounded by coarse granules and many raised bivalve pedicellariæ.

The ambulacral feet are large and strong, with large suckers.

The colors, in life, are various, and seem to differ in different localities. According to Nutting its colors in the Bahamas are often deep red relieved by the bright yellow color of the spines. "Others were various shades of red, deepening into a rich maroon, alternating with orange and yellow" (op. cit., p. 53). According to A. H. Verrill those that he saw at Samana Bay, San Domingo, were green or greenish in color, while those that he saw at Dominica Island were yellow or orange-yellow, varying to yellowish brown. According to Clark (op. cit., p. 5, 1898) it is "orange-red of some shade" in Kingston harbor, Jamaica, 
where it is plentiful. When dried it usually becomes deep terracotta color or brown.

In life it is more flexible than its appearance would indicate. Nutting states that it can curve its rays above its back until the tips touch.

This is the largest and most massive West Indian starfish and also one of the most common in shallow water. It has a wide range, extending from South Carolina to the Abrolhos Reefs, Brazil, and to the Cape Verde Islands. It is very common in the Bahamas, where large numbers were obtained by the Bahama Expedition, and about the Florida reefs and keys, as well as throughout the West Indies. Abundant at Bahia and Pernambuco, low tide to two fathoms, and at the Abrolhos Reefs (R. Rathbun). South Carolina (Agassiz).

Family Goniasterid $æ$ (Forbes), emended Verrill.

Goniasteride (pars) Forbes, 1840. Verrill, Trans. Conn. Acad. Sci., i, p. 343, 1867. Perrier (pars), Revision, Arch. Zoöl. Exper. et Gen., iv, pp. 281, 283, 289, 291, 1875; op. eit., r, p. 1, 1876.

Pentagonasterince Viguier (pars), subfamily, op. cit., vii, p. 166, pl. x, figs. $20-25,1878$.

Pentagonasteridre (pars) Perrier, op. eit., p. 231, 1884. Sladen (pars), op. eit., pp. 260, 264, 1889.

Goniasteride Verrill (restricted), Revision, in Trans. Conn. Acad. Sci., x, p. 145, 1899 (non Viguier). Fisher, op. eit., 1911b, p. 158. Verrill, op. cit., 1914a., pp. 281, 285, 286.

Phanerozonate starfishes usually having a rather broad flat or slightly convex, rather rigid disk, sometimes nearly pentagonal in form, but often stellate with more or less prolonged rays. Marginal plates usually large and thick, forming a thick, nearly vertical margin, the two rows equal or subequal.

Dorsal plates are various, but usually tesselated, polygonal, or roundish, sometimes lobed or substellate, united directly or by internal ossicles. They are commonly granulated or protopaxilliform, sometimes spinulose, or they may bear tubercles or spines; rarely naked, or covered with soft skin, with or without granules.

Interactinal plates usually numerous, angular, tesselated, or imbricated. Superambulacral plates may be present or absent. Tube-feet are in two rows and have suckers. 
Pedicellaria usually present, often large, usually bivalve, but may be multivalve, foraminate, often fossate. They may occur on any of the plates, or on the thick skin that covers them in some genera (Anthena, etc.).

This is a very extensive family, found in all seas, with numerous genera. Many of the genera are found only in the deeper waters.

It may be divided into several subfamilies. See above.

Subfamily GONiaStERIN

Genus Goniaster (Agassiz), Gray (restr.). Type, G. cuspidatus.

Goniaster (pars) Agassiz, Prod. Mem. Soc. Neufch., 1836.

Goniaster Gray, Ann. and Mag. Nat. Hist., vol. vi, p. 280, 1840. Type G. cuspidatus; Synopsis, p. 10, 1866 (non Perrier, 1876, nec Sladen, 1889).

Pentagonaster (pars) Perrier, Revis., Arch. de Zoöl., v, p. 24, 1876. Sladen, Voy. Chall., xxx, p. 264, 1889.

Astrogonium (pars) Müll. and Trosch., Syst., pp. 52, 56, 1842.

Phaneraster Perrier, Exp. Sci. Trav. and Talisman, pp. 334, 337, 387, 1894. (Type G. semilunatus = cuspidatus.)

Goniaster Verrill, Revision Genera, p. 150, 1899. Fischer, op. cit., 1911b, p. 167. Verrill, $1914 a$, p. 286.

The form is stellate-pentagonal, or stellate with a broad disk and short rays.

The dorsal plates are large, polygonal or roundish, covered with crowded, short, angular granules, with a larger marginal series; sometimes they also bear pedicellariæ. Between these there are often, in adults, many small ossicles, usually bearing groups of few granules. Papular pores are present between most of the abactinal plates, except in the small interradial areas.

One or more large, stout, conical tubercles or spines occur on more or less of the dorsal margins and abactinal plates, in adult specimens; or verruciform swellings, in the same situations, in the young. In most adults these conical spines form a central group on the disk and five large radial groups, but the number of plates that bear spines is variable; sometimes they occur on nearly all the dorsal plates.

The marginal plates are large, thick, convex, not numerous, and usually naked, except for one or two marginal series of granules, but they are more or less granulous over the surface in the very young. They are more numerous in the ventral series. The 
distal inferomarginals sometimes bear small conical spines or tubercles. Those in the dorsal series may not decrease regularly distally; the last one is sometimes as large as, or even larger than, the one that precedes it. The apical plate is small, conical.

The adambulacral spinules are numerous and closely crowded in three or more rows; the row next to the furrow series is largest. They grade into the spinulation of the interradial areas.

The interactinal plates are large, polygonal, and crowded, mostly in series parallel with the adambulacral plates, and covered with coarse granules; the granules on the center of the plates are often larger and may be like small tubercles. Sometimes a few bear conical spines.

Pedicellariæ may occur on the dorsal, marginal, and interactinal plates, and they sometimes occur, also, on the sides of the dorsal spines. They are fossate, small, high, slender, pincershaped, with spatulate blades and corresponding fossæ on the plates. They are often entirely lacking.

When very young (up to 12 or $14^{\mathrm{mm}}$ in diameter) there is no appearance of dorsal spines or tubercles and the marginal plates are few in number and granulated.

This genus is found in all the great oceans, in warm latitudes, and in shallow water or at moderate depths. The Indo-Pacific species ( $G$. cuspidatus) the type of the genus, has a very wide distribution.

\section{Goniaster americanus Verrill.}

Goniaster americanus Verrill, Amer. Journ. Sci., vol. ii, p. 230, 1871 (full description).

Pentagonaster semilunatus (pars) Perrier, Arch. de Zoöl. exper., จ, p. 24, 1876.

Phaneraster semilunatus (pars) Perrier, Sci. Exp. Trav. et Talis., p. 388, 1894.

Pentagonaster parvus Perrier, Mem. Etoiles de Mer, Nouv. Archives du Mus. d'Hist. Nat., vi, p. 231, pl. vii, figs. 7, 8, 1884. (Young.)

Goniaster americanus Verrill, Revision Genera, pp. 151-156, pl. xxiva, figs. 1, 2 (type) ; pl. xxvi, figs. 1-6, 1899.

Plate xiii; figures $5,5 a$.

The type had short rays and a broad disk; radii $35^{\mathrm{mm}}$ and $62^{\mathrm{mm}}$; ratio, $1: 1.8$. In this there are usually six superomarginal plates and seven inferomarginals on each side of a ray, but this 
number varies from less than three up to nine or more, on a side, according to age. The largest number counted by me was 19 in one interradial are on a specimen with radii $35^{\mathrm{mm}}$ and $65^{\mathrm{mm}}$.

The type has numerous conical dorsal spines, for they occur on nearly all the radial and disk plates, but not on the marginals, though some of these are swollen or somewhat tubercular. In the type the penultimate superomarginal is a little larger than those that precede it, but in others, equally large, they decrease regularly in size. One or two distal pairs are usually in contact medially.

The dorsal plates are rather large, polygonal, with regular granules. Most of them, except on small interradial areas and near the tip of rays, are surrounded by numerous (10 to 12) simple papular pores. Proximally, in adults there are, also, small, interpolated, granulated plates between the larger radial plates and between the papulæ.

On each of the distal adambulacral plates there is a single large, obtuse conical spine, outside the furrow-series of slender spinules. These spines are longer and larger than the more numerous corresponding spines of the more proximal plates. There are usually, in large specimens like the type, four stout, prismatic, blunt, crowded spinules on each plate, in the furrowseries.

This type specimen (Museum of Yale University) has a large number of high, pincer-like fossate pedicellariæ, with two slender spatulate or spoon-shaped blades, and a slightly enlarged articulating base; the blades are sometimes straight, but often more or less strongly curved to the right or left. The blades, when fully expanded, rest in socket-like depressions of the plates, which correspond in shape and curvature with the blades, so that the two belonging to a pedicellaria with curved blades, form, when taken together, a crescent-shaped or semicircular fossa, with a round central pore and a wider rounded depression at each end. Sometimes one or two granules exist close to the pedicellariæ, and when rubbed off the pits that they leave make the markings on the plates more complex.

Pedicellariæ of this form are present on a large proportion of the interactinal plates; on some of the marginal plates; on the borders of the spiniferous dorsal plates, around the bases of the 
spines, 1 to 6 on a plate; on the basal part of the spine itself; and on those dorsal plates that do not bear spines, 1 to 4 or more.

On the interactinal plates they are variously placed and irregularly oriented; most of the plates have but one, which is most commonly near the center, but many have two; those plates in the row next to the adambulacral plates usually have two or three. The pedicellariæ on the dorsal plates and on the spines are smaller than those of the lower surface, but have the same form and similar fossæ. Each pedicellaria of the interactinal and dorsal plates occupies a small, slightly elevated, smooth, rounded or ovate area, surrounded by granules. A pedicellaria and a stout blunt tubercle co-exist on some of the interactinal plates, near the jaws. Many specimens are destitute of pedicellariæ.

Some specimens have large, stout spines on several of the interactinal plates, near the jaws.

The distal superomarginal plates of some large specimens bear large, acute, conical spines. In other cases they bear lower obtuse spines, or mere tubercles. The number of rows of large radial spines is variable and also the number in a row. They may be higher and more acute than in the type, and much fewer in number.

The number in the principal radial rows varies from three to six, in the larger examples. Sometimes there are only eight to ten large spines on the dorsal side, irregularly placed.

I have examined four young specimens of this species from the Blake Exp., preserved in the Museum of Comparative Zoölogy.

Three of these were types of Pentagonaster parvus Perrier. They agree perfectly with those of similar size collected by the steamer Albatross in the West Indies. With the latter they form a complete series, connecting the smallest with the full grown examples from the same region.

The specimens next to the smallest in size are 25 to $35^{\mathrm{mm}}$ in diameter (types of $P$. parvus) and usually have six marginal plates on each side, above and below. In the smaller of these the upper and lower marginal plates and the interactinal interradial plates are nearly or quite covered with small granules, but in the somewhat larger specimens more or less of the central area of these plates is naked. Most of them show a distinct central 
swelling where the conical tubercles would have appeared later. In some the dor'sal plates are entirely covered with granules, but in others the ecntral area is naked, the amount of naked surface increasing with age, but not regularly so. The papular pores increase in number with age and cover more and more of the median radial areas and the central area of the disk, but these areas have no sharp boundaries.

The type was from off South Carolina, in rather shallow water. This species was taken by the Albatross at twelve or more stations in the West Indian region, in 21 to 50 fathoms, and by the Blake at three stations, in 84 to 129 fathoms (all young).

This, or an allied species, has been recorded from Brazil, under the names $G$. cuspidatus or G. semilunatus, which properly belong to the Indo-Pacific species. I have seen no Brazilian specimens.

Several variations (Nos. $\mathrm{A}-\mathrm{H}$ ), due largely to age, have been described by the writer. (See Revision Genera, pp. 151-155, 1899.) Details of the distribution are also given in that article.

Plinthaster dentatus (Per.) Fisher.

Pyrenaster dentatus (Per., p. 242, 1884). Verrill, 1899, p. $167=$ Plinthaster dentatus Fisher, 1911b, p. 165. (Notes on type.)

This species was recorded by Perrier (1884, pp. 170, 242), as from Blake stations, Nos. 100, 111, 260, in 250 to 1,500 fathoms, and by me (1899) from 478 to 1,639 fathoms.

Also recorded by Perrier from Blake station 264, in 41 fathoms. It is evidently a deep-sea species, of a deep-sea group. This last record is typographically erroneous, Blake station 264 was in 416 fathoms, gray ooze off Grenada. Perrier (1884) gives the depth correctly on page 180. (Table of localities, but erroneonsly in other places in the same report.)

\section{Subfamily Mediasterinæ Verrill.}

Mediasterince Verrill, Revision Genera, p. 178, 1899 ; op. cit., 1914a, p. 294.

This subfamily was proposed in 1899, for Mediaster and several allied genera, closely related to Goniasterince, but having the dorsal plates in the form of parapaxillæ, besides other characters.

Since its establishment large numbers of related new genera and species have been discovered by several deep-sea explora- 
tions, which serve to unite the two subfamilies very closely. Therefore it is now hard to draw the line between them.

It may be just as well to abandon the subfamily and unite the genera under Goniasterinæ, as Professor Fisher (1911b) has already done.

As there is but a single species, within my present limits, that can be referred with certainty to the Mediasterince, it is not my intention to discuss the question at this time, and therefore I now retain the group chiefly as a matter of convenience.

\section{Genius Mediaster Stimpson.}

Mediaster Stimpson, Journ. Boston Soc. Nat. Hist., vol. vi, p. 490, pl. 23, figs. 7-11, 1857. Type M. aqualis Stimp.

Mediaster Sladen, Voy. Challenger, Zool., vol. xxx, pp. 263, 752, 1899. Verrill, Revision Genera, p. 178, 1899. Fisher, op. cit., 1911b, p. 196. Verrill, op. cit., 1914a, p. 295.

Isaster Verrill, Proc. U. S. Nat. Mus., vol. xvii, p. 257, 1894. Type M. bairdii Ver.

Form stellate, with a broad flat disk and moderately long tapered rays.

The dorsal plates or parapaxillæ are regularly arranged in radial rows, of moderate size, somewhat elevated in the center, mostly roundish, covered with a rosette of short, obtuse spinules or granules. When these are removed the plates on the central part of the disk and along the median region of the rays appear as roundish or oval convex bosses. They are connected together by five or six internal radiating ossicles, between which are the pores for the papulæ. Thus the plates appear to be stellate at the base, though they are not actually of that shape. In a limited interradial area the plates are closely joined and tesselated. The median row of dorsal plates extends to the apical plate of the rays in the type, but not in some of the other species. Some of the plates bear a central, broad, sessile, valvular pedicellaria, which, in the type species, is nearly as wide as the plate. They are sometimes lacking. The papulæ may be single, or (as in the type) clustered.

Marginal plates are well developed, not swollen, granulated, rather numerous, higher than broad, paired, upper and lower series nearly equal in size and number, and with their sutures 
more or less closely corresponding vertically; oblique in the type. No odd interradial plate.

The adambulacral plates bear a regular marginal row of three to seven slender spinules, and usually two exterior longitudinal groups or rows of shorter spinules, which may be angular and obtuse, and toward the tips of the rays, some of them, in the type, become larger and longer. Some of these spinules may be replaced by spinuliform or clavate, two or three-bladed pedicellariæ.

The interactinal plates are angular, often rhombic, closely arranged in rows subparallel with the ambulacral grooves, covered with a rosette of granules, the central granules often replaced by a wide valvular pedicellaria. The dentary plates are not very prominent. Small superambulacral plates are present in all the species dissected.

\section{Mediaster (?) Pedicellaris (Perrier) Verrill.}

Goniodiscus pedicellaris Perrier, op. cit., 1881b, p. 23 ; Nouv. Arch. du Mus., vi, p. 245, pl. iv, fig. 3, 1884. Sladen, op. cit., p. 756, 1889.

Mediaster (\&) pedicellaris Verrill, Revision Genera, p. 183, 1899. Fisher, $1911 b$, p. 197.

One of the types of Perrier, in the Museum of Comp. Zoölogy, examined by me, had the following characters:

The radii are $18^{\mathrm{mm}}$ and $59^{\mathrm{mm}}$; ratio, $1: 3.3$. Dorsal plates, large, roundish, the summit convex when naked, but flat when covered with the spinules; the largest have abont sixteen marginal, tapered, acute spinules, and one to five or more somewhat larger, acute, central ones. Intervening papular pores large, single, about six around each plate, except that there is none between the plates in the median radial rows; a row on each outer border of the abactinal area extends nearly to the end of the rays, or to within about ten marginal plates of the end.

The median series of plates extends about four or five plates farther than the lateral, but ceases within four or five plates of the tip; from thence the marginal plates are in contact.

Superomarginal plates bevelled and covered with small, sharp, spaced spinules; the upper spinules are shorter than the lower ones, larger, stouter, acute, divergent; those around the margins are similar and do not form regular fascioles. 
Inferomarginal plates large, roundish, with one or two marginal series of sharp, divergent, stout spinules, and a central larger one. Sometimes there are three to five central spinules on the dorsal plates and on the row of plates next to the adoral plates. Pedicellariæ small, narrow, elevated, spatulate in form and rather numerous on the dorsal side.

Station 295, Blake Exped., 115 to 180 fathoms. This species was also taken by the Albatross in the West Indies.

This species, for lack of duplicate specimens, has not been dissected to ascertain the presence of dorsal connective ossicles, and therefore it is referred to Mediaster with some doubt.

Mediaster (?) agassizii Verrill, op. cit., 1899, p. 181.

This species was also taken in the West Indies by the Blake Expedition, but the locality and depth are unknown.

Genus Rosaster Perrier.

Pentagonaster (pars) Perrier, op. cit., p. 22, 1881; Etoiles de Mer, p. 238, 1894.

Rosaster Perrier, Exped. Trav. et Talisman, p. 386, 1894. Verrill, Revision Genera, p. 197, 1899. Fisher, op. cit., 1911b, p. 164.

Stellate with slender rays and large disk, marginal plates large, regularly paired, covered with spinules; no spines on dorsals.

It has rounded, columnar, paxilliform abactinal plates (parapaxillæ), covered, like the marginal and interactinal plates, with small spinules. Most of the superomarginal plates of the rays are in contact medially.

The inferomarginal plates are spinulose and agree in number, position, and nearly in form with the dorsals. Interactinal plates are thick, closely arranged in two or more chevrons on the triangular interradial area; each row has an impaired median plate; they are spinulose.

Adambulacral plates do not have a prominent inner angle. They bear a straight furrow-series of four or five slender spines, and on the actinal surface two or three larger erect spines, which form a regular row. Superambulacral plates are small. Fossate pedicellariæ with spatulate valves are often present on the dorsal plates; smaller erect ones sometimes occur on the marginal and adambulacral plates. 
The paxilliform dorsal plates are thick and have slightly lobed bases (usually six lobes); they are united by these lobes, without intermediate ossicles, and have isolated papular pores in the intervening spaces; the median radial row is distinct but like the others. On the disk the five interradial primary plates are much larger than the others, round, tabulate, and spinulose.

The marginal plates are separated by deep ciliated grooves, but are not fasciolated.

Only one species of the genus is known.

\section{Rosaster alexandri Perrier.}

Pentagonaster alexandri Perrier, Bull. Mus. Comp. Zoöl., ix, p. 22, 1881. Nouv. Arch. du Mus., vi, p. 238, pl. vi, figs. 3-8, 1884.

Rosaster alexandri Per., Exp. Sci. Trav. et Talism., Echinod., p. 387, 1894.

Verrill, Revision Genera and Species of Starfishes, p. 197, 1899.

Plate xi f figures $3-3 b$, details. Plate xvii; figure 2.

Form small, stellate, with a large disk, incurved sides, and rays tapering to slender tips. Radii of a specimen taken off Havana, by the Bahama Expedition, $7^{\mathrm{mm}}$ and $15^{\mathrm{mm}}$; ratio, $1: 2.12$; marginal plates nine, large.

The six superomarginal plates that form the evenly ineurved margin of the disk are distinctly larger than those on the rays; they are wider than long, convex, and rise above the paxillar area, forming a stout border. Those on the rays are at first rectangular but decrease rapidly in size and become square. Seven pairs are in contact medially. Ocular plate is broad ovate, not notched above. The marginal plates are covered with spaced small, short, rough spinules, smaller and acute above, larger and more obtuse or clavate on the outer side and along the margins of the sutures, which have deep grooves, but are not fascioled.

The dorsal paxillar area is pentagonal, not extending beyond the basal radial plates. The radial areas are covered with regularly stellate parapaxillæe, which have a thiek six-lobed base and a short eylindric, or slightly tabulate, central boss or column, surmounted by a divergent stellate group of about eight to ten short slender spinules, surrounding a larger, slightly spiniform central one. The spinules are very regularly arranged, and are minutely thorny at the tips. In each of the intervals between the basal lobes there is a papular pore. In the interradial area 
there is a small group of seven to ten more irregular plates, closely joined and without intervening papulæ. On the radial areas there is a median row of parapaxillæ, not differing from those adjacent.

Around the center of the disk there are five interradial, round, tabulate parapaxilla, more than twice as large as the others and covered with similar rough spinules of which there may be sixteen to eighteen marginal and ten to twelve in a central group.

The small convex madreporic plate is attached to the outer edge of one of these plates, which are united to five smaller radial plates; within these there is a group of six plates of which one is central and a little larger than the others, which are like the radials, and have intervening papular pores. No dorsal pore is ordinarily visible.

The inferomarginal plates agree closely with the upper ones in size, form, ciliated grooves and spinulation, and stand exactly opposite them. The interactinal plates are few relatively large, thick, slightly lobed within, and are closely united or else slightly overlap by their edges. They bear small, upright, rough, acute spinules, six to eight surrounding a central one on the larger plates. These plates form a continuous row of nine next the adambulacrals with the impaired plate next the jaws. In the second row there are about five small plates, with the median one impaired.

The adambulacral plates are small, short, rectangular, two of them about correspond to one of the larger interactinals; and three distally to one marginal. Their inner margin is very straight and bears an even row of four or five very slender subequal spines, which completely interlock across the narrow groove. On their actinal surface they have two upright, longer and somewhat larger acute spines, side by side; on the adoral plates these became decidedly larger and longer. On a few of the adambulacral plates there is an upright small two-valved, spatulate pedicellaria.

No pedicellariæ were found on the upper side of this specimen, but on some others a few of the dorsal plates have one or sometimes two, fossate pedicellarix with spatulate valves.

It was taken by the Bahama Expedition on the crinoid ground, off Havana, in about 200 fathoms. 
It was taken at several stations by the Blake, in 84 to 1930 fathoms; and by the Albatross at a number of stations in the West Indies and Gulf of Mexico, in 98 to 980 fathoms. A number of specimens were taken, off Havana, on the cinoid grounds in 98 to 201 fathoms.

\section{Subfamily Leptogonasterinæe Perrier.}

\section{Genus Anthenoides Perrier.}

Anthenoides Perrier, Bull. Mus. Comp. Zoöl., vol. ix, p. 23, 1881; Etoiles de Mer, p. 246, 1884. Verrill, Revision of Genera, p. 173, 1889. Fisher, op. cit., p. 173, $1911 b$.

Disk broad with regularly incurved borders and rapidly tapering rays, becoming slender distally. Both series of marginal plates are well developed, opposite, paired, and form a stout border to the disk and rays. Radius of disk is equal to about ten proximinal marginals.

Dorsal plates are polygonal or slightly lobed, nearly equal, pretty closely joined in mosaic, with small papulæ between them. The median radial row is distinct. There are few or no secondary plates except next the radial rows.

All the plates, above and below, are covered with a thin smooth dermis, partly concealing the plates.

All the marginal, interactinal, and dorsal plates are more or less granulated, beneath the dermis.

The inferomarginal plates have one or more larger granules, tubercles, or small spines on the outer end; in the larger specimens forming a row of spinules.

Interactinal plates form a large area, extending to about midlength of the ray. They are polygonal and closely joined. Those next the adambulacral plates and near the jaws mostly bear a bivalve pedicellaria with short valves.

The adambulacral plates have an inner regular row of several (5-8) small spines, and an actinal row of two or three larger ones.

\section{Anthenoides peircei Perrier.}

Anthenoides peircci Perrier, op. cit., p. 23, 1881; Etoiles de Mer, p. 247, pl. viii, fig. 1, 1884; Comptes rendus, 1889, p. 60. A. Agassiz, Three Cruises Blake, vol. ii, p. 103, fig. 379, 1888.

Anthenoides (?) Nutting, Narrative, p. 169, figure 1, 1895. 
Plate iii ; figure 2. Young. Plate $\mathrm{x}$; figures 1-1b, 2-2f. Details.

Disk broad more or less swollen; with evenly incurved margins, bordered by rather large, stout, marginal plates, and covered with numerous pretty regularly arranged polygonal plates, which form the median radial rows. Rays rapidly tapered becoming slender distally, bordered by smaller convex plates, which are in contact distally. All these plates are finely granulated beneath a thin dermis that covers them, but does not entirely conceal their outlines.

The type of Perrier had the radii $32^{\mathrm{mm}}$ and $80^{\mathrm{mm}}$; ratio, $1: 2.5$. It had about 27 marginal plates, on each radial side. He mentioned others of larger size. One had the radii $53^{\mathrm{mm}}$ and $156^{\mathrm{mm}}$. Another had them $33^{\mathrm{mm}}$ and $131^{\mathrm{mm}}$. These were from 151 to 150 fathoms. One taken by the Bahama Expedition had the larger radius about $62^{\mathrm{mm}}$; diameter $125^{\mathrm{mm}}$, or about five inches.

The inferomarginal plates, in the larger specimens, have a marginal row of several small spines, or even more than one row, on the interradial plates, when they become larger.

Sometimes there is a ridge or line of coarser granules along the superomarginal plates, on large specimens.

The interactinal plates are numerous, extending to middle of rays. They are polygonal, closely joined, granulated, and with a thin outer dermis. Those next the jaws and adjacent to the adambulacral plates bear a low, bivalve pedicellaria.

The adambulacral plates have a furrow-series of about six to eight small graded spines, the largest in the middle; on the actinal side there is another row of about three larger and shorter spines. Very young specimens of this species have an appearance quite unlike the adults, and may be mistaken for some other species. $^{18}$

This was taken by the Bahama Expedition on the Pourtales Plateau, in 80 fathoms ("five inches in diameter"). Young ones were taken in 60 fathoms, off Key West, station 26. It was dredged by the Blake in 151 fathoms off St. Lucia; in 150 fathoms, off Guadeloupe; 85 and 82 fathoms, off Barbados; 73 fathoms, station 290, off Barbados (young); and at station 266, in

18 In the Blake collection some young from station 243, in 82 fathoms were labelled "Dorigona bifurcata Perrier, MSS.," but other similar specimens were correctly identified and labelled by Perrier. 
461 fathoms, off Granada (very young). The bottom at these stations was sand and shells or gray sand, except that in 85 fathoms, which was "hard."

\section{Family Chætasteridæ Ludwig.}

Chotasterine (subfamily of Linckiadx) Sladen, Voy. Chall., xxx, pp. xxxv, 397, 1889. Perrier, Exp. Trav. et Talism., p. 328, 1894.

Linckiade (pars) Viguier, op. cit., vol. vii, p. 147, 1878. Perrier, op. cit., 1884, p. 164.

Chatasteridce (family) Ludwig, op. cit., 1899. Fisher, op. cit., 1911b, pp. $18,21$.

Stellate starfishes with elongated well rounded rays and small disk. Dorsal and marginal plates similar in several definite rows, elevated in the middle and bearing slender, divergent paxilliform spinules; some plates may be larger and nodulous. Internally they have radiating comnective ossicles. Papular pores dorsal, mostly isolated, none intermarginal. Adambulacral plates have a marginal row of slender spinules and a group of small ones on the actinal side. Ampullæ single. Odd interradial marginal plates may be present. Interradial septa calcified. Pedicellariæ unknown.

Genus Chætaster M. and Trosch. (emended), type, C. subulata.

Chetaster (pars) M. and Tr., 1840, p. 321. Syst. Ast., p. 27, 1842. Perrier, Revis. Stell., Arch. Zoöl. Exper. et Gen., v, p. 249, 1876 (not deseribed). Viguier, Arch. Zoöl. Exper., vii, p. 152, pl. x, figs. 8-13, 1878 (structure).

Chataster Sladen, op: cit., vol. xxx, pp. 397, 398, 399, 1889.

Nepanthia (pars) Gray, 1840, p. 287; Synopsis, p. 15, 1866.

Chataster Fisher, op. cit., 1911b, pp. 18, 20, 21.

Characters are included in the description of the family. ${ }^{19}$ It is the only genus. Very few species are known.

The type species is C. longipes (Retz.) = Asterias subulata Lam., found in the Mediterranean and East Atlantic, off the Azores, etc., and ranging down to 1100 meters or more.

19 The position of this family is uncertain. The character of the plates and spinulation is much like those of Henricia, of the Echinasteridx. It agrees with that family in having simple ampullæ. 


\section{Cifetaster nodosus Perrier.}

Chataster nodosus Perrier, Arch. Zoöl. Exper., v, p. 250, 1876. Sladen, Voy. Chall., xxx, pp. 398, 399, 778, 1889.

Chctaster longipes (pars) Sladen, op. cit., p. 399, 1889.

Plate viii; figures 1, 2. Plate xiii; figures 4, 4a. Details.

Rays five, nearly terete, long, slender, regularly tapered to unusually slender tips and bearing large, scattered, tubercular plates. Disk small, margins rounded. Radii of one $10^{\mathrm{mm}}$ and $74^{\mathrm{mm}}$; ratio, $1: 7.3$; of another, $9^{\mathrm{mm}}$ and $76^{\mathrm{mm}}$; ratio, $1: 8.5$.

The dorsal and lateral surfaces of the rays are covered with eleven radial rows of plates, five on each side and one carinal or median, the latter similar in size and form to those adjacent.

The lower ones, on each side, are smaller and their rows cease at about the middle of the rays; near the tips there are but five rows. These plates have an expanded base and an elevated central portion, which is smaller, transversely elliptical, nearly flat on the top, which is covered by numerous small, slender and delicate hyaline spinules; those around the margin are longer, very slender and when perfect interlock across the spaces intervening between the plates. They break off easily at the base and then the plates appear granulated.

The larger tubercle-like plates are often three to five times larger than the others, and much more elevated; they are round or elliptical, convex, and covered with very numerous small slender, rough spinules, those on the middle shorter. These large nodular plates are irregularly distributed and differ in number on the several rays; the number is often twenty to twenty-five. They occur both on the median and lateral radial rows of plates, but not on the disk in our examples.

Papular pores of rather large size occur singly, in rows between all the dorsal and dorso-lateral rows of plates except next the marginals. There are about two to each plate.

The two regular rows of marginal plates are situated well down on the ventral side. They are larger than the adjacent lateral plates, thick, transversally oblong proximally, becoming squarish and then rounded distally, convex and covered like the dorsals with very numerous slender, minute, rough spinules, 
which form a very regular marginal fringe, but they are shorter than those of the dorsals. The interspaces between these plates and between the two rows are narrower than those of the dorsal surface and contain no papular pores. The two rows are much alike, but the lower ones are larger.

The adambulacral plates are similar in form, about one-fourth as large, two of them corresponding to one inferomarginal. Each one bears a crowded group of slender, rough, hyaline spinules on the actinal surface, and a crowded furrow-series of four to six somewhat larger ones. Within the outline of the disk these spines, and also those of the actinal side, become much longer and setiform.

There is a small triangular group of interactinal plates, spinulated much like the dorsals, with rough hyaline spinelets.

The dorsal plates of the disk are rounded, smaller than those of the rays, but spinulated in the same way. The madreporite is small and covered with similar spinules.

Taken by the Bahama Expedition at station 16, of Havana in 200 fathoms, (specimen described above), and at station 7, off Havana, 140 fathoms, one specimen. The type was from off Guadeloupe.

The tuberculated specimens taken off Bermuda, in 30 fathoms, by the Challenger and referred to $C$. longipes by Sladen, belong apparently to this species.

\section{Chetaster longipes Sladen (?).}

Chcetaster longipes Sars, op. cit., p. 107, 1857. Sladen, op. cit., p. 399, 1859 (not described). Perrier, op. cit., p. 329, 1894 (not described). Asterias longipes Retzius, Diss. Aster., p. 20, 1805.

Asterias subulata Lamarck, op. cit., p. 568, 1816.

Chcetaster subulatus Müll. and Troschel, op. cit., p. 27, 1842.

Sladen states that his Bermuda specimen is young, and has some nodosites, which recall those of $C$. nodosus Perrier.

Probably it was a young specimen of the latter, which occurs off Florida in similar depths. C. longipes is a Mediterranean species, ranging to the Azores.

Off Bermudas, in 30 fathoms, and off Fayal, Azores, in 450 fathoms (Sladen), East Atlantic, in 102 to 1139 ineters (Perrier.) 


\section{Family Odontasteride Verrill.}

Gnathasterince (pars) Perrier, Exp. Trav. et Talism., pp. 244, 251, 1894.

Odontasteridae Verrill, Revision Genera and Species of Starfishes, p. 201, 1899. Fisher, op. cit., $1911 b$, pp. 18, 153. Verrill, op. cit., 1914a, p. 302.

Form either pentagonal or stellate with a broad disk. Marginal plates well-developed in both series.

Jaws, each with a single, recurved, more or less hyaline median spine, or with two such spines, side by side. In the latter case one of these spines arises from near the apex of each oral plate. Both conditions sometimes occur, abnormally, on the same specimen.

An odd interradial marginal plate, above and below, on each side.

The marginal plates are covered either with spinules or granules; sometimes the upper ones are granulated and the lower spinulose, like the corresponding disk-plates; they usually have deep fasciolated sutures.

Abactinal surface covered with more or less paxilliform plates, parapaxillæ or protopaxillæ, with intervening large papular pores on the radial areas.

Interactinal plates angular, covered either with spines or granules. Small simple pedicellariæ sometimes occur on the interactinal or abactinal plates. They may have two, three, or four papilliform blades.

Adambulacral plates usually bear elongated spinules arranged in three or four pairs of small transverse rows, generally only two or three of the furrow-series are on each plate; sometimes only one. Oral plates usually have elongated, acute marginal and apical spines. They are sometimes closely united along the median suture; in other cases (Odontaster), they are separated by a space covered only by membrane.

\section{Genus Odontaster Verrill.}

Odontaster Verrill, Amer. Journ. Science, xx, p. 402, 1880. Proc. U. S. Nat. Mus., xvii, p. 262, 1894. Amer. Journ. Sci., xlix, p. 136, 1897.

Gnathaster Sladen (pars), Voy. Challenger, vol. xxx, Asteroidea, p. 285, 1889. Perrier (pars), Exp. Trav. et Talism., p. 244, 1894.

Odontaster Bell (pars), Proc. Zoöl. Soc., London, p. 260, 1893. Verrill, Revision Genera and Species of Starfishes, p. 205, 1899. Fisher, op. cit., $1911 b$, p. 154 . Verrill, op. cit., $1914 a$, p. 303.

Form stellate, with a wide disk and short rays. 
A single, odd, hyaline, recurved movable spine is on the apex of each jaw. The oral plates are large, partly separated by an open fusiform space covered by membrane. Abactinal surface covered with elevated, convex or clavate paxilliform plates, or parapaxillæ, which usually bear clusters of elongated spinules, like true paxillæ; their bases are stellate. The upper marginal plates are usually finely spinulated.

The adambulacral plates usually bear several rows of spines, usually three or four in the furrow-series, rarely but two.

The odd interradial marginal plate is usually triangular or wedge-shaped. Simple pedicellariæ occur rarely.

The radial abactinal plates form more or less evident obliquely transverse rows and some extend nearly or quite to the apical. plate.

Papular pores are generally large and placed singly in the angles around the radial parapaxillæ.

The inferomarginal plates and interactinal plates are covered with acute, more or less elongated spinules.

\section{Odontaster hispidus Verrill.}

Odontaster hispidus Verrill, Amer. Journ. Sci., vol. xx, p. 402, 1880. Proc. U. S. Nat. Mus., vol. xvii, p. 263, 1894. Amer. Journ. Sci., vol. xlix, p. 136, 1895; Verrill, Revision Genera and Species of Starfishes, p. 205, pl. xxix, figs. 8, $8 a, 1899$.

Plate xiii; figure 6.

Form depressed, stellate, with a rather broad disk. Radii vary in proportion from $1: 2$ to $1: 3$. A large example has the greater radius $55^{\mathrm{mm}}$; lesser, $16^{\mathrm{mm}}$.

The marginal plates are only moderately developed and do not eneroach much on the disk, either above or below. In large examples there are about 37 to 39 on a side, in each series. They are convex and separated by wide and rather deep sutural grooves. The upper and lower nearly coincide. The upper ones are squarish, with rounded angles; the lower ones, along the disk margin, are higher than long. The odd interradial one is somewhat wedge-shaped, and only a little smaller than those adjacent to it.

The abactinal plates are round at top, convex, well separated; those of the radial areas and center of the disk are elevated, with a somewhat capitate top, covered by a dense cluster of slender, 
elongated, acute, divergent spinules. Between most of the radial plates, over a large area, there are moderately large papular pores, about six around etch plate. Smaller pores are scattered over the center of the disk, but they are absent from small interradial areas and from the distal part of the rays.

The interactinal plates all bear dense groups of rather stout, elongated, tapered, mostly acute or subacute spinules, essentially like those of the lower marginal plates.

The marginal plates of both series are densely covered with small elongated, divergent spinules which overarch and partly conceal the sutural furrows. The spinules on the upper plates are slender and acute. Those on the lower plates, especially those on the actinal side, are longer and much stouter, terete and tapered, subacute or acute.

The jaws are rather large, rhombic; the two plates are separated by a rather wide sutural furrow covered with membrane; they are covered with spines on the margin and actinal side, like those of the adambulacral plates. The median, reeurved epioral spine is large, somewhat compressed; the distal part is hyaline and very acute.

The adambulacral plates are transversely oblong, rather narrower than the adjacent interactinal plates. Each one, proximally, bears two, or more often three, unequal spinules of the furrow-series, but more distally they bear only two, nearly equal ones. On the actinal face each plate bears about four or five quite similar spines, which sometimes seem to stand, more or less distinctly, in pairs. These spines, like those of the furrowseries, are essentially like those of the interactinal plates, in size and form.

Regularly 4-rayed and 6-rayed specimens have been taken.

It is easily distinguished from our other species by the small marginal plates and stout interactinal spinules.

This species was taken by the U. S. Fish Commission at many localities, from off Martha's Vineyard to Florida, in 43 to 480 fathoms and more.

The Albatross also dredged another speeies in the West Indies, which is similar to $O$. setosus Ver., if not the same. 


\section{Suborder Nотомчота (Ludwig).}

Benthopectinide + Pontasterince Verrill, Revision Genera Starfishes, p. 217, 1899.

Pararchasterince Sladen, Asteroidea Challenger Exped., pp. xxviii and 4, 1889. Perrier, op. cit., 1894, p. 252.

Notomyota Ludwig (as an order), with families Cheirasterida and Benthopectinidce Ludwig, Notomyota eine neue Ordnung der Secsterne. Sitzungsb. Köng. Preuss. Akad. Wissensch., vol. xxiii, pp. 435-466, 1910. Verrill, op. cit., pp. 283, 310, ${ }^{*} 1914 a$ (as a suborder.)

Benthopectinida Fisher, op. cit., 1911b, p. 120.

This group includes starfishes, mostly from the deep sea, having long, angular, subacute rays, in which there is a dorsal pair of special muscle bands rumning from the base to near the tip, and serving to curve the rays upward over the back. The podia are large and tapered, with a small terminal sucker, marginal plates of both rows are well developed with a tendency to become more or less alternate and often oblique. Their sutures are usually more or less fasciolate.

In the interradial angles some of the genera (e.g. Benthopecten) have an impaired median, marginal plate in both series; sometimes in only one series. Other genera have no odd plate. The marginal plates usually bear one or two long spines in both series and the surface is covered with acute spinules.

Dorsal surface is covered by protopaxillæ, parapaxillæ, spinose parapaxillæ, or simple spinose plates, rarely with true paxillæe.

Papulæ may be distributed over much of the dorsal surface of the rays, or may be limited to the proximal median part of the rays, or concentrated in specialized areas (papularia) near the base of the rays.

Actinal interradial area is small or may be nearly abortive; it is sometimes occupied by one to six or more large pectinate pedicellariæ.

Similar pectinate pedicellariæ may occur between the plates, on the marginals, or on the dorsal surface. Bivalve pedicellariæ occur in some genera.

Adambulacral plates have the inner end angular or prominent and projecting into the groove. It bears a row or comb of numerous slender spines; one, two or more larger spines stand on its actinal face, and sometimes a pedicellaria.

\footnotetext{
* Misspelled as Myonota on pages 283, 310, 311.
} 
The most distinctive feature is the presence of a pair of definite dorsal muscle bands in the rays, extending from near the base to the tip and enabling the rays to be bent strongly upward with great facility. The order Notomyota was based on this character, as the name implies.

The large pectinate pedicellariæ, with numerous incurved papillæ, sometimes arising from and between two plates, are also characteristic of this group, but they are sometimes lacking, especially in the young.

\section{Family Benthopectinidæ (Verrill) Fisher.}

Benthopectinidee and Pontasterince Verrill, Trans. Conn. Acad. Sci., x, pp. $200,217,1899$.

Parachasteridce Sladen, op. cit., 1889, p. 4.

Benthopectinidae Fisher, 1911b, p. 120 . Verrill, op. cit., p. 310, 1914a.

An almost strictly deep-sea family. Form stellate; disk rather small; rays five, elongated, with two rows of thick, spinose, marginal plates, which are not exactly paired, but are sometimes alternate, or nearly so. Adambulacral plates are angular and have elongated furrow-spines and one or more enlarged actinal spines.

The species of this family are numerous and occur in all oceans, but they are nearly all deep-sea species. Some of them extend to the greatest depths from which starfishes have been obtained. Only a few occur in depths less than 150 fathoms, none are found in very shallow water.

Those genera that have an impaired interradial marginal plate were formerly placed by me in a special family, Benthopectinida, later reduced to a subfamily, Benthopectinince. The discovery of certain deep-sea species that vary in this respect, and others that are intermediate, renders it useless to longer maintain such a subfamily group. Benthopecten spinosus Ver. occurs in very deep water off the Atlantic coast of the United States. Other species occur in all the oceans.

It is represented in the West Indies by $B$. simplex (Perrier), which occurs in 1323 fathoms (Blake Exped.). Redescribed in detail (op. cit., 1894, pp. 254, 256) as Pararchaster simplex. It was described from a very young specimen. 


\section{Genus Cheiraster Studer.}

Cheiraster Studer, Sitzungs. Naturf. Freunde, Berlin, xvi, pp. 130, 131, 1883; Anhang z. d. Abhandl. d. k. preuss. Akad. Wiss. Berlin, pp. 49, 51, 1884. (Type is C. gazellœ Studer.) Perrier, Exped. Trav. et Talisman, p. 269, 1894. Sladen, op. cit., 1889, pp. 3, 25. Ludwig, Notomyota, pp. 442, 454, 1910. Fisher, op. cit., 1911b, pp. 120, 123.

Pontaster (pars) Sladen, op. cit., pp. 23, 25, 1889. (Type of Pontaster is P. tenuispinus.)

Benthopectinidæ which normally have no odd interradial marginal plates. The papulx, situated at the base of the rays, are not gathered into a special, median papularium, but form a bilobed group, often U-shaped or V-shaped, which, in the adult, may contain many papulæ and cover most of the base of the ray and extend on the disk but in the young it may contain only one to three or four pores and show no evidently bilobed character. The apex of the group is directed toward the disk.

The central part of the disk may, in the adult, bear a cluster of more or less numerous long acute spines, but these are few or lacking in the young, and in the adults of some species.

The dorsal surface is closely covered with low, round or angular irregularly arranged parapaxillæ or spinoparapaxillæ. A boss or short columnar process arises from the flatish plates, and is surmounted by a stellate marginal serics of spinules or granules, and with one or several central spinules, which may be spiniform in some species, or granule-like in others. Distally the radial plates may become flatter, minute protopaxillæ.

The two rows of marginal plates are well-developed and usually decidedly alternate, and more or less angular, with oblique sutures. Each plate of both series usually bears one large acute marginal spine; often one, especially the lower one, may have one or several smaller secondary spines around its base. The surface of these plates is covered with small spinules or spiniform granules, larger beneath; the inferomarginals may also have one or two transverse rows of spines beneath, in some species.

The proximally angular adambulacral plates have a marginal series of numerous slender graded spines on the inner edges, which is continuous with a series of smaller spines around the outer margin. In the center of its actinal surface, each plate has one or two, or sometimes alternately one and two, larger, acute, usually erect spines. 
Pectinate pedicellariæ may be present on the interactinal plates, or between them, or on the inner end of the inferomarginal plates, or sometimes on the adambulacrals. They may be few or many, or entirely lacking, especially in the young.

Ludwig (op. cit., 1910) made the external generic distinction between this genus and Luidiaster almost entirely dependent on the presence of one spine, in this, on the actinal side of the adambulacral plate, while in Luidiaster there are two or more. This, however, is not a valid generic difference, for several of the species have either one or two, on consecutive plates, and nearly all have two, in large specimens, on some of the plates.

The internal dorsal muscular bands of the rays are not attached to a crest of the proximal ambulacral ossicles, in those species examined. According to Fisher, this is the most definite character for separating it from Luidiaster. The same character seems to separate it from Pectinaster. But the muscular bands are not known in many species. Dry specimens and unique types cannot be examined as to this feature.

Young specimens less than $20^{\mathrm{mm}}$ in diameter usually cannot be referred with any certainty to either genus, for their papularia, pedicellariæ, and characteristic marginal spines may be lacking or rudimentary.

\section{Cheiraster mirabilis Perrier.}

Archaster mirabilis (pars) Perrier, Bull. Mus. Comp. Zoöl., vol. ix, p. 27, 1881; Nouv. Arch. du Mus., vol. vi, p. 256, pl. 9, fig. 4; not pl. viii, figs. 7, 8, (nor pl. x, fig. 3), 1884.

Cheiraster coronatus (pars) Perrier, Exp. Sci. Travail. et Talisman, Echinod., p. 271, 1894.

Archaster coronatus (pars) Perrier, op. cit., 262, 1884; op. cit., p. 271, 1894 (full deser. two varieties.)

Cheiraster coronatus (pars) Ludwig, Notomyota, op. cit., pp. 455, 456, 1910.

Plate xiv; figures 5, 5a. Details.

The type of this species, as described by Perrier in 1881 and copied in 1884, is the very same specimen (from station 148, St. Kitts) as that described by him in 1894 (p. 271), as "Cheiraster coronatus" "A. Premier type, bras ellongés," and there made the typical form of the latter. This is, of course, contrary to the ordinary rules of nomenclature, for mirabilis has three years 
priority, and was described from a single type-specimen..$^{20} \quad C$. coronatus was not described till 1884, and its type was from off Havana, in 805 fathoms, No. 2.

Therefore his $C$. coronatus of 1894 is the same thing as his $A$. mirabilis of 1881 . Whether his $C$. coronatus of 1884 is a distinct species, is another question, to be settled only by a new study of the type, or other specimens identical in character.

The type of this species, according to the revised description by Perrier $(1894$, p. 271$)$ under the later name of $C$. coronatus, has the following characters:

Radii $10^{\mathrm{mm}}$ and $85^{\mathrm{mm}}$; ratio, $1: 8.5$. The rays are long and slender. Marginal plates forty to forty-two. The center of the disk has about a dozen large spines.

The superomarginal plates are rather small, imbricated, their proximal convex border alone being visible. They agree in number with the inferomarginals, but are not in line with them. Their surface is covered with numerous fine spinules. Those beyond the third bear a large conical marginal spine; that on the fourth plate is usually much larger than the others. Those of the first to third plates are more or less aborted.

The inferomarginal plates are covered with long and slender spinules; on the first three plates there are also four or five spines, increasing in size upward; on the fourth plate the large marginal spine becomes 7 to $8^{\mathrm{mm}}$ in length; those beyond gradually decrease in length; below the large spine there is usually at least one secondary spine. Some of these plates have a rudimentary fasciculate pedicellaria.

The dorsal plates are numerous, small, rounded, flat, covered with extremely small spinules, almost reduced to the form of granules visible only with a lens.

The center of the disk has about a dozen long, conical, movable spines. (Condensed from Perrier.)

The papular pores form two symmetrical lateral groups, which are prolonged toward the center of the disk and become coalescent at a larger radial plate. Five larger interradial plates are

20 At the end of the 1851 description there is a brief description of another specimen, which in 1884 he made the type of a new species ( $A$. insignis), which is now Dytaster insignis. Thus the name mirabilis cannot be applied to any species except that first described, with the type specimen, from Station 148, in 380 meters, off St. Kitts, as its sole type. 
also distinguishable. Some of the plates on the papular areas are enlarged and similar to those that have a central spine. The madreporic plate is large, round, and covered with radial gyri. It is surrounded by plates bearing larger spinules; that on the adcentral side is largest.

The adambulacral plates project into the groove; the inner edge bears ten to twelve graded spines, the middle one longest; the rest of the margin, on the actinal side, bears about a dozen very small conical spinelets. On the center of the actinal face there is one large, movable, conical spine. On some of the plates there are one to three small spinelets around its base. (In some of our specimens part of these plates have two unequal, long, slender spines.)

The interactinal plates form three series; the first has six plates (three each side); the second has four; the third two. These plates bear a set of spines about parallel with the adambulacrals; one of the inner plates of the first row is longer and larger; other small spinules cover the plates.

Two or three pectinate pedicellarix occur on the sutures of these plates, one on each series. They have five or six papillæ on each half.

The jaws are prominent, each half is wedge-shaped, and bears about eleven marginal spines, the two inner much the larger; the lateral ones slender, subequal. Epioral spines are numerous; three inner ones are larger.

Some of the specimens before me agree well with the characters given by Perrier for his original type, and agree with some of his cotypes that I have studied in the Museum of Comparative Zoölogy. Many of these are evidently immature.

Perrier (1894, p. 271) made the presence of a group of spines on the center of the disk the special character of this species (under the name coronatus) and stated that this separates it from all the other species of the West Indian fauna.

In this statement he certainly went too far, for at least two other species have the same feature. Very likely, therefore, he still included in his species specimens of more than one species.

He recognized two varieties: one with short and the other with long rays, the latter being the typical mirabilis, as shown above. The form with short rays may be distinct. Its type was from 
station 238, in 127 fathoms, off Camman. It may be identical with $C$ echimulatus Per., as now understood by me. It is perhaps the form figured by Perrier (1884) on pl. $x$, fig. 2.

Ludwig (op. cit., p. 455, 1910) considered C. mirabilis the young of coronatus and erroneously adopted the latter name. The name mirabilis has three years of priority. Moreover the type specimen of mirabilis was larger than that of coronatus. Perrier, 1894, kept the two as distinct species, though he displaced the names and put his former types of coronatus with that of mirabilis.

With only the records given by Perrier, it is not possible to give accurately the distribution of this species in the Blake dredgings, separately from the other forms compared with it by him, in 1884, for in most cases he gives no information even as to the presence of spines on the disk. The following stations, however, are valid for this form:

Station 148, off 'St. Kitts, in 208 fathoms, fine sand; station 238, off Grenadines, in 126 fathoms, coral sand; station 264, off Grenada, in 416 fathoms, gray ooze; station 291 in 200 fathoms, off Barbados. Most of the above have been confirmed by examinations of the specimens.

It was also taken by the Albatross at a number of stations, in similar depths. The Bahama Expedition dredged specimens at station 2, off Havana, in 210 fathoms.

\section{Cheiraster mirabilis coronatus (Perrier).}

Archaster coronatus Perrier, op. cit., 1884, p. 262.

Cheiraster coronatus Perrier (pars), 1894, pp. 271, 275 (not the form then described).

C. coronatus (pars) Ludwig, op. cit., pp. 455, 456, 1910.

The type of this species, as originally described by Perrier, in 1884 (p. 262) was from Blake station 2, in 805 fathoms. Its characters, which were given briefly, are as follows:

Radii $8^{\mathrm{mm}}$ and $65^{\mathrm{mm}}$; ratio, $1: 8.1$. Superomarginal plates 43 . The rays are slender and long, with the interradial angles scarcely rounded.

The superomarginal plates are longer than broad, angles rounded; each bears one median marginal spine; that of the 
fourth plate is larger than the others; those of the two more proximal plates ${ }^{21}$ are much smaller; none on the first.

Inferomarginal plates have a marginal spine much larger than the others, surrounded at base by several sinaller spines less than half as long; otherwise the plate is covered with small spinelets.

The dorsal paxillæ are rather small, covered with equal small spinules. About fifteen long, slender, acute spines surround the center of the disk. Madreporic plate is small, prominent, rounded, pretty coarsely grooved, situated near the marginal plates.

The interactinal plates are in a single series with small spines. (No pedicellariæ are mentioned.) The adambulacral plates bear a semicircular row of nine graded marginal spines, and a single straight, long, slender, acute spine on the actinal face.

The jaw-plates bear, each, ten marginal spines, decreasing from the oral end backward, and also some small epioral spines, both on the surface and bordering the naked sutural area between them.

The papular pores are not mentioned by Perrier, nor any pedicellariæ.

So far as his description shows, there is no character by which this form is distinguishable from typical C. mirabilis, but a reexamination of the type is desirable, especially with reference to the papular arrangement and the special characters of the dorsal parapaxillæ.

Among my notes, made when I examined the Blake collection, in 1899, there is no mention of the type of this species. Probably I did not see it. Most likely this is only a slight variation from the typical form of the original $C$. mirabilis, as suggested by Perrier himself, in 1894. The only point worthy of note, in the description of Perrier, is the apparently more spinose condition of the inferomarginal plates, in this respect approaching those of $C$. echinulatus. Perrier gave only two localities : station 2, off Havana, in 805 fathoms, and station 19, off West Florida, in 310 fathoms (one very young).

21 Perrier says third and fourth plates, evidently by an error, for second and third. In this respect his description, when corrected, applies well to his figure, pl. ix, fig. $4=C$. mirabilis. 


\section{Cheiraster echinulatus Perrier.}

Archaster echinulatus Perrier, Revision, vol. v, p. 268, 1876; Etoiles de Mer, p. 263, pl. x, fig. 4, 1884 .

Cheiraster echinulatus Perrier, Exped. Trav. et Talisman, p. 278, 1894 (brief description.)

Pectinaster echinulatus Ludwig, Notomyota, pp. 449, 450, 1910 (no description.)

Plate xiv; figures 2, 3. Details. Plate xix ; figure 2. Plate xxv; figure 1.

The single specimen originally described by Perrier, from off Barbados, was very young, and most of those later listed from the Blake Expedition are also small. Neither of his descriptions are very complete, nor does his small photographic figure give much aid in identification. I have examined part of the specimens recorded by him, however, and therefore refer much larger specimens to his species.

According to Perrier (1876) his type had the radii $4^{\mathrm{mm}}$ and $16^{\mathrm{mm}}$; ratio, $1: 4$; marginal plates, 15 . The largest specimen mentioned later had 19 marginal plates. Some of our specimens have 26 or more.

In the type the adambulacral plates had a circular marginal group of ten to twelve slender spines, the largest on the inner angle, and one larger spine on the center of the actinal face.

The inferomarginal plates have one marginal spine, not particularly long, and several unequal secondary spines, below its base, some of which are not very much shorter than the large one. The superomarginal plate has one larger spine, as in most species.

The papular pores were "one to three at the base of the rays, near the median line."

The dorsal paxillæ were rather large, with about ten marginal granules.

The jaw-plates have each a row of about nine long, slender, close spines, with the two rows opposed to each other, and a larger tooth-like spine. ${ }^{22}$

22 The type, according to Perrier (1876), came from off Barbados, in 100 to 315 feet, Hassler Expedition. Probably fathoms were here intended for most of the Hassler dredgings there were in 75 to 100 fathoms, and this is a rather deep-water species. 
These details are now given because this was the first species of the family to be described from the West Indian fauna, and because, owing to its marked immaturity, its identification, from the imperfect description, is difficult. Moreover, there has been a question as to its generic place, since Ludwig has referred it to Pectinaster and has made it the young of my Pontaster sepitus (1885) 1895.* Both these conclusions are erroneous.

In 1884 , Perrier only added that only two interactinal plates separated the inferomarginals from the jaws (a feature of the young); that these plates have pectinate pedicellariæ; that the dorsal paxillæ have a central caducous spinule; that the ambulacral feet have small suckers; that the number of marginal plates varies from fifteen to nineteen; that the dorsal marginal spines have a number of spinules around their base; and that in the larger specimens some pretty long spines surround the center of the disk.

Most of these features are common to several other species, especially when young. The last two are of most importance, though other related species have spines on the disk.

The most distinctive character given is the presence of numerous secondary spines around both series of larger marginals.

In 1894 he referred the species to Cheiraster, although he recognized Pontaster and Pectinaster ${ }^{23}$ as distinct genera; and stated that it is nearly related to C. mirabilis but may be distinguished by its shorter rays, broader at base; its circular pectinate pedicellariæ; its larger inferomarginal spines, accompanied by several spines of smaller size; and by the larger size of the dorsal paxillæ. He adds that the interactinal plates are two to six in a single range (a youthful character).

In neither place does he describe the correct arrangement of the papulæ, which would be the only character by which it could be distinguished from Pectinaster. This we can now supply by

* Archaster sepitus Verrill, Amer. Jour. Sei., vol. xxix, p. 151, Feb., 1885; Expl. by the Albatross in 1883, pp. 519, 543, 1885. Pontaster sepitus Verrill, Proc. Nat. Mus., vol. xvii, p. 247, 1894; ditto, vol. xlix, p. 137, 1895. Range, 368 to 858 fathoms. Taken at several stations between N. lat. $41^{\circ}$ $53^{\prime}$ and $39^{\circ} 40^{\prime}$.

23 Ludwig (1910) referred this species to Pectinaster. Perhaps he was misled by Perrier's imperfect description of the papular areas. Perrier apparently saw but one limb of the V-shaped group. 
means of larger specimens. In his immature specimens the papular areas were feebly developed, and probably hard to see.

The Bahama Expedition dredged four good specimens at station 61 . One of these, in alcohol, has the radii $9^{\mathrm{mm}}$ and $36^{\mathrm{mm}}$; ratio, $1: 4$. Marginal plates 26 .

It has about twenty larger, tapered, acute spines on the central part of the disk, with a number of others bordering and on the papular areas, not so large, and grading down to the spinose parapaxillæ of the radial area, which are scattered among the ordinary form, even to the distal fifth of the ray, those beyond the basal part of the ray having the central spinelet small, but acute, surrounded on the larger ones with an inner circle of about eight to ten very small clavate spinules, and an outer circle of twelve to sixteen or more. Those plates that lack the acute spinelet have a central clavate spinule like those around it, or often two or three of them. Toward the tips of the rays the plates become very small, closely crowded, so that when denuded they are polygonal and in mosaic. They bear few granule-like spinules in small rosettes.

The papular pores are in a bilobed or V-shaped group, the apex adcentral, each limb having two rows of six to eight each. The two limbs are separated at first only by the single median row of plates, more distally by two or three rows. The two main rows of each limb are separated by a single line of plates, and they converge adcentrally, and finally are united by a line of two or three pores just adcentral to the largest spine on the group, arising from a prominent plate, in the apex of the $\mathrm{V}$. The papular pores are very small and difficult to see, even with a good lens, on some of the specimens. There is sometimes a third short outer row of papulæ on each limb in the larger specimens.

The superomarginal plates are rather large, convex, and encroach upon the disk forming a strong narrow border, widest in the interradial areas, where the sutures are transverse. Beyond the third plate the sutures become more and more oblique and the plates more rhomboidal. Each of these plates, except the first, bears an acute tapered, slender spine, not very long, hardly equal to the length of two adjacent plates. That on the fourth plate is not notably enlarged, those on the second and third be- 
ing only a little smaller. The first plate usually has the spine rudimentary or lacking. Below the base of these spines there are proximally usually two or three small, acute, secondary spines. The surface of the plate is covered rather thickly with short, acute, erect spinules; those below the spine are longer. The sutures between the plates are wide, but only feebly fasciolated.

The inferomarginal plates are thick and form a strong raised border to the under side of the disk and rays, which appear sunken below the border. These are more strongly spinulose than the upper ones, especially on the outer part, where the spinules become large and sharp. Each of the plates bears one large marginal spine, similar to the dorsals, but rather longer. Below this, on the proximal plates there is a double group of five or six secondary spines, one or two of them about half as long as the large one. More distally these become reduced to two or three. These and the coarse spinules between them give the under surface a very spinose appearance.

The adambulacral plates have a very prominent inner angle which bears a row of eight to ten slender graded spines, continued around the actinal edges by more slender spinules. On the actinal face are borne proximally either a single large tapered spine, or else two unequal spines; in the latter case the smaller spine may be on the aboral or on the adoral side of the larger one. The plates with two spines may alternate irregularly with those with only one. Beyond the middle of the ray most of the plates bear two nearly equal spines.

The interactinal plates form, on each area, one row of about eight plates, and a shorter row of four or five small plates.

Pectinate pedicellarix, broad ovate in form, with raised borders, are present over the sutures between part of the larger interactinals. There may be from one to four on each area; most often two; sometimes none. These plates also bear a central spine, with basal spinules around it. Peroral spines are rather large and stout.

These specimens are considerably larger than those seen by Perrier, but they differ little except in those features naturally due to increased age. In my specimens the character of the papular areas is that of typical Cheiraster, and not at all like Pectinaster, in which Ludwig placed the species. 
The localities where it was taken by the Blake, as recorded by Perrier, were mostly in the Gulf of Mexico, off West Florida and Alabama, in 84 to 229 fathoms. I have also seen it from station 158 (?), off Montserrat, in 147 or 148 fathoms.

It was taken by the Albatross at several stations in the West Indies, among others at station 2125, in 208 fathoms, off Curacoa, No. 10,109, Nat. Mus. (See plate xiv, fig. 3.)

By the Bahama Expedition it was taken at stations 31, 35, 61, off Key West, Fla., in 75 to 100 fathoms (see plate xix, fig. 2); and at station 2, off Havana, in 110 fathoms. (See plate xiv, fig. 2.)

Cheiraster planus Verrill, sp. nov.

Plate xviii; figure 2. Type.

Of this species I have seen but one specimen (No. 18469, Nat. Mus.).

The disk is rather wide for the genus and the rays long, becoming very slender distally. Radii are $13^{\mathrm{mm}}$ and $92^{\mathrm{mm}}$; ratio, $1: 7$. Marginal plates, 39 . Radius of disk is equal to five and one-half proximal plates. Paxillar area is equal to three times the breadth of second marginal plate.

The superomarginal plates of the rays are rather large, somewhat convex, forming a thick but not wide somewhat raised border. They are rather rhomboidal with oblique sutures and alternate with the lower ones.

Each bears a rather long, slender, terete, regularly tapered, acute spine, in length about equal to two plates; that on the fourth plate not much larger than the following; those on the second and third are somewhat smaller; the first very small. Rest of the plate nearly uniformly covered with very small, slender, acute, spaced spinelets; the sutures are fasciolated with more slender spinules.

Inferomarginal plates have a similar marginal spine, but with one or two secondary spines, not half as long, below it on the proximal plates; elsewhere the surface is covered with acute spaced spinelets, larger than those on upper plates, grading downward to short appressed conical forms. About sixteen proximal adambulacral plates correspond to the first ten inferomarginals. 
very small, roundish plates that are not much crowded. They bear a very small stellate group of minute spinules, which, on the larger radial plates, form a marginal row of about six to nine, around a central one of the same size or slightly larger and acute. Those on the papular areas, around the madreporic plate and on the central part of the disk are partly larger with larger and more numerous spinules. On the papular areas, interradial areas, and near bases of the rays some of them bear a small central spine; some of these exceeding the diameter of the plate. These are not found much beyond the bases of the rays, except a few sparsely scattered along the ray, of smaller sizes.

The papular areas are large and well defined, U-shaped, with two rows of about six or seven pores in each limb. They are slightly raised above the general level.

The madreporic plate is irregular in form, not very large, deeply grooved, and surrounded by six enlarged parapaxillæ.

The combined jaw-plates are broad-ovate with the oral edge broadly rounded and bearing four rather large and stout, blunt peroral spines; on one jaw there is a median odd one, deeper in the mouth. The lateral marginal row has six slender spines. Epioral spines are not very numerous, in two or three rows on each side, the anterior pair larger.

The adambulacral plates have a prominent obtusely angular and rounded inner margin, which bears a row of eight to ten slender graded spines, continued along the actinal edges by smaller spinelets. The actinal face has one rather large and stout, tapered, central spine; some few plates have a smaller secondary spine.

The interactinal plates form two rows; counting both ends the first row has eight or ten plates; the second has about four, with others rudimentary. They are spinulated like the inferomarginals and some of the larger ones have a central erect spine.

No pedicellariæ of any kind could be found.

This is a very distinct species, unless some of the young, without discal spines, called mirabilis by Perrier, prove to be its young. Most of them, however, have a very different papular area, when any is visible. The absence of pedicellariæ may be merely an individual peculiarity, but is unusual in this genus, with specimens so large. 
All the marginal plates have clearly fasciolated sutural grooves.

This specimen was taken by the Albatross in the winter of 1885 , in the West Indies, but the locality was not recorded. (No. 28469, Nat. Mus.)

Cheiraster enoplus Verrill, sp. nov.

Plate xviii; figure 1. Type.

A large species with a wide, flat disk and long, tapering, angular rays, armed with two rows of long, tapered, acute spines, one to a plate, and with a central group of 12 to $15 \mathrm{long}$, slender, acute spines on the disk. Superomarginal spines are nearly confined to lateral surfaces, so that the paxillar area is wide and covered with very small, even parapaxillæ.

Radii of the type are 21 and $185^{\mathrm{mm}}$; ratio, $1: 9$. Marginal plates about sixty. The sides of the disk are evenly and broadly incurved, and in the median interradial areas the superomarginal plates searcely reach the upper edge and do not form a rim, but farther out they form a narrow, slightly raised rim. The primary plates and those more central bear each a long, slender, terete, very acute spine, about fifteen altogether. The central plate and spine are the largest.

The general surface of the disk and rays is covered very closely with very small rounded, convex, low parapaxillæ, covered with minute spiniform granules or with short, minute spinules. Those on the disk and bases of rays are larger, and have about 10 to 15 spinules around the edge, and a central rosette of three to twelve granules; about midlength of the rays they may have only six to eight marginal spinules and one or two central granules. Toward the tips of the rays they become almost microscopic.

Many of the larger parapaxillæ on the papular areas, and on the interradial areas have a small, erect, acute central spine.

The madreporic plate is large and convex with radiating gyri. It is surrounded by six convex paxilliform plates, larger and higher than the rest, each bearing a small spine.

The papular areas are large and broad, occupying more than half the width of the base of the ray, and extending, on the disk, to the eluster of long spines. There may be more than 200 small papulæ in each half. 
The half areas are long elliptical, pointed distally and divergent, united at two places by narrow cross-rows of papulæ.

The superomarginal plates are small, narrow, convex above, angular below, alternating irregularly with the lower series. The surface is evenly covered with very small, acute spinuliform granules, similar to those of the adjacent parapaxillæ. Each bears one large, outspreading, terete, evenly tapered, very acute spine, some of them $15^{\mathrm{mm}}$ long, or as long as the width of the ray at base. They have no secondary basal spines. Those on the first three interradial plates are much smaller than most; the first one is smallest. The fourth and fifth are largest; beyond that they decrease regularly.

The same arrangement, as to size, holds good for the inferomarginal spines, which are of similar length, but rather more slender. But these last have a group of three to five unequal smaller sized spines below them, one of which may be half as long as the primary spine. A row of similar acute spines extends along both the transverse under margins of the plate, two or three in each row, proximally. The rest of the surface is covered with small, erect, acute spinules. Close to its inner end there is often one (sometimes two) small, low, papilliform pedicellariæ, with six to eight small convergent valves.

The interactinal plates are in three chevron-like rows. The first forms a rather long row, next the adambulacrals; each half has six or seven plates. Each plate bears one or two slender spines, and usually a papillose, elliptical pedicellaria, with twelve to sixteen incurved papillæ. These often cover more than half the plate. Others of similar size and form occur in the sutures between two plates.

The adambulacral plates have a prominent, widely curved or often nearly semicircular inner edge on which there is a regular row of about 10 to 12 slender graded spines; this row is continued on the adoral and aboral edges by about six to eight much smaller spines or spinules. The actinal surface is concave and bears usually two long, rather slender spines, which on the proximal plates become more and more unequal, the outer spine becoming shorter and smaller, until on the basal three or four plates it is reduced to a rudimentary condition and may entirely 
disappear on some plates. A few miliary spinelets may occur around the bases of the large ones.

The combined jaw-plates are broad and short, with a wide elliptical suture, and a very broadly curved peroral edge, which bears two pairs of stout, blunt, peroral spines, the two middle ones considerably larger. The adoral row on each side has eight to ten slender spines, like other adambulacrals in size, but in a slightly curved row, the most adoral spine longest. Epioral spines are not very numerous, slender, acute.

The type, and only specimen seen, is from Albatross station 2128, N. lat. $19^{\circ} 55^{\prime} 46^{\prime \prime}$; W. long. $75^{\circ} 49^{\prime} 23^{\prime \prime}$, south of East Cuba, in 400 fathoms, blue mud and fine sand. (No. 7425, Nat. Mus.) It is dry, color yellowish brown.

In general appearance this is like Luidiaster, but it has the pedicellariæ and papulæ more like those of Cheiraster. I attach no generic importance to the presence of two large adambulacral spines on most of the plates.

The dry specimen affords no chance to ascertain the attachment of the radial muscular bands, which seems to be the only real distinction between the two genera.

Genus Pectinaster Perrier (emended).

Archaster (pars) Perrier, Etoiles de Mer, p. 263, 1884.

Pectinaster (pars) Perrier, Ann. Sei. Nat., vol. xix, p. 70, 1885 (type $P$. filholi Per.) ; Exped. Trav. et Talisman, p. 278, 1894. Ludwig (emended), Notonlyota, op. cit., p. 448, 1910. Fisher, op. cit., 1911b, p. 122.

Pontaster (pars) Sladen, op. cit., p. 23, 1889.

Cheiraster (pars) Ludwig, Asteroidea, p. 1, 1905.

Form regularly stellate, with regularly tapered angular rays, normally five. Odd interradial marginal plates lacking. Dorsal radial paxillary areas rather narrow, reaching the tip of the rays, covered with small, roundish, low or convex plates, bearing small spinules and often a larger central spine, on some of them.

Papularia specialized at base of rays, medial or central, and more or less smaller, but not two-lobed.

Marginal plates are well developed, usually not particularly large, more or less out of line in the two rows, so that the vertical sutures do not correspond, and are somewhat oblique. Those of both series are spinulose and bear one large spine, often with one 
or more smaller ones at its base. The sutures are more or less fasciolated.

Interactinal plates are present, in small numbers. They are spinulose and may have a central larger spine, and often sutural pectinate pedicellariæ.

The adambulacral plates have a prominent inner angle, which bears, at its edge, a row of six to ten or more spines; the actinal side has one or two large central spines and often a smaller accessory one, besides some small basal spinules. Sometimes there are two or more equal spines.

The pericellarix are fasciculate or pectinate. They may occur on any series of plates; rarely on the adambulacrals. Those on the interactinals are pectinate and usually largest. They may cover the suture between two plates, or occupy a single plate. Those on the dorsal plates are small, fasciculate, and are not always present.

The dorsal muscle-bands are well developed. Their proximal ends are attached to one or two ambulacral plates and to the superomarginals.

This genus is closely allied to Pontaster. The latter (typical) differs chiefly in having two-valved pedicellariæ, instead of pectinate ones; and in their position, for they mostly occur on the adambulacral plates. These plates also have two or more larger spines on the actinal side, instead of one or two, as is usually the case in this genus.

The number of actinal adambulacral spines cannot be trusted as a true generic character, for it varies on different plates of the same ray, but in this genus they seldom form a cluster, as they sometimes do in Pontaster.

Typical Pontaster also has more crowded papulæ and more specialized papularia, with a more complex calcified inner structure, and they are therefore more swollen externally than in this genus, in which they are sometimes scarcely at all swollen, especially in the young.

Fisher (1911b) made the bivalve form of the pedicellariæ and their position on the adambulacral plates the most diagnostic character to separate Pontaster from Pectinaster. This seems to me the most useful and most available method, except in those rather unusual cases when no pedicellariæoccur, and in the very young. 
Young specimens, up to $25^{\mathrm{mm}}$ in diameter, are often generically undeterminable, if pedicellarix are not present. At this stage of growth there is usually only one papular pore developed, but that is median at the base of the ray. A little later two more appear, one each side of the first. These and later conditions may coëxist on the different rays of the same specimen, owing to unequal rates of development.

This genus is common in moderately deep water of all the oceans. Some of the species descend to great depths.

\section{Pectinaster vincenti (Per.) Lindwig.}

Cheiraster vincenti Perrier, Exped. Trav. et Talisman, pp. 270, 275, 1894 (short description.)

Archaster mirabilis (pars) Perrier, Etoiles de Mer, p. 256, 1884 (= No. 231, p. 258.)

Luidiaster vincenti Ludwig, Notomyota, op. cit. 1910, pp. 452, 453, 1910.

According to the brief description given by Perrier in 1884 (p. 258) this species has the following characters, based on the types from station 231 :

The rays are rather short; radii are $10^{\mathrm{mm}}$ and $50^{\mathrm{mm}}$; ratio, $1: 5$. Superomarginal spines are 28. There are no large spines on the central part of the disk. The adambulacral spines have, on the actinal side, a groun of three or four spines, instead of one or two as usual.

The superomarginal and inferomarginal spines are shorter than in $C$. mirabilis.

The dorsal parapaxillæ have mostly a larger spinule in the center.

The pectinate pedicellarix, on the interactinal plates, are well developed, but variable in number and position, even on the different areas of the same specimen. There may be from one to four, or none at all on any one area.

In 1894 (p. 275) a few additions are made to the description: The large inferomarginal spine is accompanied by two or three smaller spines irregularly placed, and not constant.

The papulæ are arranged in a small median group, not very prominent (as it is in Pontaster, sp.). He compares it to Pectinaster oxyacanthus (Sladen, as Pontaster) but finds it quite distinet. As Perrier states dictinctly that the papularium is central "sur une plage impaire," this species should be placed in Pectinaster, not in Luidiaster, where Ludwig located it, or else 
in Pontaster, if the character of the pedicellariæ be ignored, for in the type of the latter the pedicellariæ are bivalved. Moreover, in typical Pontaster the papularia are more swollen and have a specialized calcareous framework internally.

The type was from station 231, off St. Vincent, in 95 fathoms (six specimens). The specimens from this locality, in the Blake collection, I have seen. They are all young except one.

Pectinaster mixtus Verrill, sp. nov.

Cheiraster mirabilis (pars) Perrier, op. cit., 1884 (non 1881), p. 256, pl. viii, figs. 7,8 ; op. cit., p. $276 c$, pl. xx, fig. $4,1894$.

Plate vi; figure 2. Plate xv; figure 2. Plate xvii ; figure 1.

It seems necessary, or at least desirable, to have a special name for the very common and often abundant small form of this group found in the West Indies. It is probably more abundant and more widely diffused than any other starfish of that region, in moderate depths. It also has a considerable range in dèpth.

At present it is impossible to tell whether any of the specimens are mature. Most are evidently immature, but cannot be referred to either of the larger species with certainty. Certainly they are not all of one species, as first described. Large numbers of specimens have been grouped together by Perrier (as his C. mirabilis of 1894, not of 1881). I have examined a considerable number of his lots, but not all, and have found some evidently mixed lots, including, for instance, the young of $C$. echinulatus. Others might be the young of $C$. planus or $P$. vincenti. Still, most of them appear to belong together. I propose to call the nore common species, provisionally at least, $C$. mixtus $=C$. mirabilis Per., 1894, in part. Although the specimens are probably all immature I am unable to refer them to either of the larger species described.

A specimen that agrees very closely with the one described by Perrier comes from Albatross station 2341, off West Florida, in 143 fathoms (No. 10,226, Nat. Mus.). This may be taken as the type. (See plate vi, figure 2.)

It has the radii $6^{\mathrm{mm}}$ and $26^{\mathrm{mm}}$; marginal plates 22 . The dorsal plates are nearly flat, polygonal, closely packed or tesselated, unequal in size. They bear numerous minute, almost granule-like 
spinelets in a rosette of two circles on the larger plates, about ten to twelve in the inner circle and twenty to twenty-four or more in the outer one, and many of the larger plates have an erect central sharp spinelet, often more than twice as long as the diameter of the plate. There is no central group of larger spines on the disk, but some of the plates there are a little larger than the average.

The papular pores are in a small, median, specialized cluster of five ol six. A central larger pore is surrounded by four plates, a little larger and more prominent than those adjacent, and with a rather larger central spinelet. The side of each plate next the pore is angulated and bears a miniature comb of minute spinules. Thus the four plates are convergent over the pore, and appear to be movable, to some extent, like an opereulum, for in some cases they lie flat and conceal the pore and in other cases they have the inner end raised, exposing it. 'Two of these plates are in the median radial line; the others are between them, to right and left. ${ }^{24}$ Two or four smaller pores appear between the outer angles of these four plates. No others are visible on some of the rays; on other's an additional small pair appears more distally. The central dorsal pore is distinct.

The superomarginal plates have a small acute spine; that on the fourth plate is only slightly longer; some of the more proximal plates have two spines, one above the other.

The inferomarginal plates have one marginal spine, equal to the upper ones, and also have a group of four to six or more secondary sharp spines, of unequal sizes, below their base, some of them half as long as the marginals. These grade downward into numerous sharp spinelets that closely cover the inferior surface, the lower ones minute.

The adambulacial plates have a prominent angulated inner end and bear a series of about seven to nine very slender spines on the edge. The actinal face usually has two elongated, very slender, sharp, unequal, larger spines. Sometimes a fasciculated, papilliform pedicellaria, with about four valves, replaces the two spines on some of these plates.

24 These appear to be the same as those spoken of by Perrier as four plates forming a cross. 
The interactinal plates form one row of four or six, and four rudimentary plates of a second row.

Pectinate pedicellariw, nearly circular in form, exist between most of the plates of the first row and rudimentary ones between those of the second row, so that there are three, four, or more on each area.

'The four apical or peroral spines are much stouter than the adorals and blunt, the two central ones most so, but not long. Each row of adoral or lateral spines has about nine slender, closely packed, subequal, and not very long spines. There are ten to twelve crowded, small epioral spines on each jaw-plate, the adoral one larger.

Younger specimens, with the greater radius 12 to $13^{\mathrm{mm}}$, have the same form and many of the special characters are developed. They have 12 marginal plates, obliquely placed. There is but one papular pore on each radial area. That is median and represents the larger median pore of the type. It is surrounded by four polygonal plates. When the dorsal plates are denuded of spines they appear closely united in a mosaic; they are of unequal sizes, larger than in most species, only slightly convex, and distinctly polygonal. On the disk and bases of the rays they are larger and many are regularly hexagonal. They retain the polygonal form nearly to the tips of the rays.

Adambulacral plates have six to eight very slender furrowspines and part have two slender spines on the actinal side. There are only four interactinal plates, and only one rudimentary pectinate pedicellaria, in some; while in other young of similar size there are two pedicellariæ to each area.

According to Perrier's description in 1894 (p. 276) of what he then called $C$. mirabilis the specimens (mostly very young) had the following characters:

The larger radius does not exceed $30^{\mathrm{mm}}$. The superomarginal plates are twenty-two; they stand obliquely and alternate with the lower ones and extend somewhat onto the upper surface; their outline, seen from above, is a parallelogram with inclined sides; they are covered with small spinules and have one pretty long marginal spine on each plate.

The inferomarginals are a little longer than wide; they are covered with small spines and have one long acute marginal 
spine, as long as a plate, often with a smaller spine at its base. Sometimes there is a small pectinate pedicellaria between two of these plates.

The dorsal parapaxillæ have roundish, flat bases, and bear about thirty almost granule-like, obtuse spinules and on most of them a delicate central spinelet.

The papulæ, at the base of each ray, vary from one to eight, according to age. One of these is larger than the rest and is situated in the median radial line. It is surrounded by four plates, which form a cross, and they are larger than those adjacent. The other papulæ are situated in the same transverse line, or. else a little more distal.

The interactinal plates are six to eight and form only one row. In the suture between some of them there is a pectinate pedicellaria, with six to eight papillæ; other pedicellariæ, smaller in size, may be present.

The adambulacral plates project strongly into the groove and each bears an inner nnarginal row of eight graded spines; other smaller spines continue the rows on the actinal edges. A large spine stands on the actinal side, sometimes accompanied by a smaller spine.

Several of the characters given above are due to immaturity, especially the small number of papular pores, of marginal plates, and of interaetinal plates. M. Perrier here restricts the name mirabilis to those specimens that lack long spines on the central part of the disk. This feature is, without doubt, in some cases due to immaturity and yet there are allied species that do not have them, even when of large size. Therefore there may be more than one species among the numerous small speeimens listed by Perrier as $C$. mirabilis, without central spines. A young specimen of the same species (No. 18,470 Nat. Mus.) differs only in characters due to its less development. Radii are $4^{\mathrm{mm}}$ and $18^{\mathrm{mm}}$. Its dorsal plates are flat, polygonal, and tesselated quite regularly. This feature alone is sufficient to distinguish it from the young of other species of similar size. Most of the larger dorsal plates have an acute, erect, central spinelet. Its papular pores are single on some of the rays. In that case there is only the primary pore surrounded by its four special plates. On some of the rays a small pore has already appeared on one 
or both sides of the first, between the outer angles of the four plates, but not always in the same angles. The inferomarginal spines are surrounded by basal secoudary spines as in the larger specimens. (See plate xvii, figure 1.)

The spines of the jaws and adambulacral plates are essentially the same as in the older specimen described above; part of the adambulacral plates even have two larger spines on the actinal face.

Interactinal row of plates is single, having two larger and two very small plates. Two or three small pectinate pedicellariæ have already developed on each area.

This is undoubtedly young. In the strong spinulation of the inferomarginal plates and the group of several secondary spines below the marginal one it is much like $C$. echinulatus, but the latter has a group of long spines on the disk; a different arrangement of papulæ; relatively coarser protopaxillæ, with fewer and smaller central spinelets. It seems hardly probable that it can be the young of echinulatus, for there is no great difference in size between this and some of the latter, nor is there any reason to think that the arrangement of the papular pores can change from the condition characteristic of Pectinaster to that of Cheiraster, especially in specimens nearly of the same size.

Whether this species ever develops large spines on the disk, when older, I cannot say. I have seen none with such spines.

This species, as listed by Perrier, was taken by the Blake Expedition at about 42 stations (not all recorded by Pcrrier), nearly all were between 73 and 314 fathoms. One was taken in 805 fathoms, off Havana; one in 611 fathoms, off Dominica, station 175; one in 1,030 fathoms, off Martinique, station 196.

Although I studied a large number of specimens of this species in the Blake collection, I have no memoranda in respect to these three from great depths. Perhaps some of them may be distinct. Perrier himself makes no remark about either, except the first, from 805 fathoms, which he says is a large specimen without pedicellaria. (Compare my C. planus.)

The Blake localities are nearly all among the Lesser Antilles. Three are in the Gulf of Mexico, off West Florida and Alabama, in 84 to 229 fathoms. I have no data sufficient to list all the 
forms without discal spines separately, for Perrier did not designate them and I did not examine nearly all the lots.

The Albatross also took this species in many localities, in the same region. The type (No. 10,226 Nat. Mus.) was from 143 fathoms, off West Florida.

It was taken by the Bahama Expedition at station 2, off Havana, in 210 fathoms.

Among those listed by Perrier as C. mirabilis there were probably some of the following species:

\section{Pectinaster gracilis Verrill, sp. nov.}

Plate vi; figure 1. Type. Plate xiv; figure 4. Plate $x v$; figures 1-1b.

Regularly stellate, with slender, tapering, depressed, acute rays. Radii of the type, which is probably immature, are $5^{\mathrm{mm}}$ and $30^{\mathrm{mm}}$; ratio, 1:6; another of same lot has them $4^{\mathrm{mm}}$ and $30^{\mathrm{mm}}$; ratio, $1: 7.5$.

The dorsal plates are roundish or elliptical, very unequal in size, somewhat convex, not crowded, nor closely tesselated. They bear a rosette of about six to eight very small clavate spinules, and most of the larger ones have a small upright, central spinelet, often as long as the diameter of the rosette; seldom twice as long. Near the tips of the ray the rosettes become minute and crowded, and the paxillary area very narrow.

The papular pores are five to seven on most of the rays. The primary central pore is larger than the others and is surrounded by about five to eight somewhat thickened and enlarged convex plates; usually two pairs are situated near it, one a little more distal and the other a trifle more proximal, and wider apart, or else in the same transverse line, so that they form either a trapezoid or rectangular figure, when regularly developed, but both in a pair may not appear at the same time; one or sometimes two, additional small ones appear on some of the rays, more distally, and sometimes a small pair more proximally. Thus it is probable that older specimens may have at least four pairs. Specimens slightly smaller than the type, in the same lot, have only three or four papular pores. Owing to the higher and thicker plates around the central and adjacent pores, the 
papular area shows as a small convex or raised area, covered with paxillæ rather larger than those near by, and some of the plates may bear a central spinelet larger than usual. There are no larger central spines on the disk. The madreporic plate is small with few gyri it is separated from the marginal plates by four or five rows of very small plates.

The jaws are relatively unusually wide and short, about as wide as long, convex, and laterally broadly rounded. The marginal spines are longer than usual, slender, divergent, not erowded, about six on the convex lateral margin, besides the apical or peroral one, which is larger and longer than the others, and acute. Each half of the jaw has about ten to twelve small spinelets, irregularly disposed, the two groups separated by a slightly prominent narrow carina, with no naked median sutural area.

The superomarginal plates have each a moderately long, slender, terete, acute spine. They are about equally spaced and pretty regularly graded, so that they form a very regular row. They have no secondary spines at the base. The rest of the plate is finely spinulose.

The inferomarginals also bear a similar marginal spine, without secondaries, their surface is covered with small, sharp, spaced spinules becoming very small at the inner end.

The adambulacral plates have a furrow-comb of seven or eight slender spines, continued around the actinal edges by several much smaller, slender, irregular spinules. The actinal face bears one (or sometimes two) rather long, slender, acute spines. About fifteen adambulacral plates correspond to ten inferomarginal plates.

The interactinal plates form a single chevron of about six spinulose plates. Only one or two rudimentary pedicellariæ are beginning to form on some of the areas. On specimens of the same lot, slightly smaller, there are only four interactinal plates and no trace of pedicellarix.

In form, size and general appearance this species resembles $P$. mixtus. It can be readily distinguished by the dorsal plates, which are rounded and convex, while in the latter they are flat and closely tesselated, as well as larger; in this the jaws are 
wider and their marginal spines and apical spines are fewer and much longer, and more acute; this also lacks the secondary spines below the inferomarginal one, which are a prominent feature in $P$. mixtus as well as in Cheiraster echinulatus and C. mirabilis. The arrangement of the papular pores and surrounding convex rounded plates is also characteristic.

Very common in the West Indies, in 70 to 300 fathoms.

The type (No. 10,564 Nat. Mus.) and cotypes were taken by the Albatross, but no station number is given. I have seen many others from the West Indies, in the Blake collection. The specimen figured on plate xv, figs. 1-1b, is from 126 fathoms, Antilles.

\section{Pectinaster oligoporus (Perrier) Verrill.}

Pontaster oliogoporus Perrier, Exped. Trav. et Talisman, p. 293, 1894. Archaster mirabilis (pars) Perrier, op. cit., p. 259, 1884.

The description given by Perrier $(1894$, p. 293) is very brief and mostly comparative, as to $P$. limbatus Sladen. The type and only specimen was young and came from station 143, Blake. According to Perrier its peculiarities are as follows:

$\mathrm{He}$ states that it is a typical Pontaster, with seven or eight papulæ united in a single group upon the median line, at the base of the rays, and says that according to Sladen's analytical key it would come next to $P$. limbatus, ${ }^{25}$ but in the new species the jaws are less spinose; the adambulacral spines are ten to twelve, and form a complete circle around the plate, and the the papulæ, instead of being in longitudinal rows, are in two or three irregular transverse rows. Also, there are eight interactinal plates in a single row. There are no pedicellariæ of any kind.

The type of this species, which I have not seen, was a "unique" specimen from Blake station No. 143, in 150 fathoms, ooze and sand, off Saba Bank, N. lat. $17^{\circ} 30^{\prime}$; W. long. $63^{\circ} 42^{\prime}$ $35^{\prime \prime}$.

$25 P$. limbatus, with which Perrier compared his new species, has no large spines on the disk, it has numerous small secondary spines around the base of the large inferomarginal spine, and the under side of the inferonarginal plates is thickly covered with coarse acute spinules; the upper marginal plates encroach on the disk; the dorsal paxilla have central spines; the adambulacral plates have two or three acute spines on the actinal face; the papularia are swollen, elliptical. 


\section{Pectinaster dispar Verrill, sp. nov.}

Plate xiv; figures $1,1 a, 1 b$. Details.

The superomarginals are large and wide, encroaching on the paxillary area, thus forming a wide and thick border. They have wide and deep, fasciolated, oblique, sutural grooves. Each bears one large spine of moderate length, about equal in length to one and a half times that of the plate. The breadth of the plate is more than half that of the radial paxillary area proximally.

The paxilliform plates are mostly small, stellate, spinose protopaxillæ. They bear six to eight long and acute marginal spinules, and a longer central, erect, acute spine. Their radiating spinules are longer, fewer and more spine-like than in any of our other species. The papular pores form a small, central, transverse group, with about four larger pores on each side of the central one, without specialized plates.

The inferomarginal plates are large and broad and have their lower surface closely covered with rather large, short, stout, acute, conical spinules, that are appressed and almost imbricated in about six alternating rows. They are stouter and more conical than in any of the other species, but not so long as in $C$. echinulatus. They increase in size and length outwardly. These are followed by three or four larger, unequal secondary spines around the base of the large, stout, marginal one. Some of the secondaries are more than half as long as the large one. The grooves between the plates are fasciolated with slender interlocking spinules.

The adambulacral plates are large and prominent. The marginal edge bears a row of ten to twelve, or more, long slender graded spines. The rows are continued all around the margin of the plate by ten to twelve smaller and more slender spines. The actinal face bear's two larger and very unequal spines. The larger one is very stout, conical, acute, not very long. The other is very slender, equally long, tapered, acute.

The type was from an Albatross station, locality unknown. (No. 18,468, Nat. Mus.) 


\section{Genus Luidiaster Studer.}

Luidiaster Studer, Sitzungs. Naturf. Freunde, Berlin, xvi, pp. 130, 131, 1883 ; Anhang Abhandl. K. Preuss. Akad. Wiss., Berlin, pp. 49, 51, 1884. Ludwig, Notomyota, 1910, p. 451. Fisher, op. cit., 1911b, p. 127. Verrill, op. cit. p. 311, 1914.

Acantharchaster Verrill, Proc. U. S. Nat. Mus., xvii, p. 268, 1894. (Type, A. dawsoni Ver.)

Rays usually five, angular, tapered. Disk small. Interradial actinal plates few, confined to the disk, spinous and with pectinate pedicellariæ.

The dorsal surface is covered with small, unequal, thin plates, mostly in the form of protopaxillæ and spinose parapaxillæ. ${ }^{1}$ The latter have a low, round column and bear a large, central, articulated spine surrounded at base by a circle of small spinules; they are found on the disk and usually along the median part of the rays. The protopaxillæ are smaller, and part of them bear only small spinules; others have a small central spine. The papulæ occur, in the adults, on most of the disk and entire basal part of the rays. Marginal plates of moderate size, more or less alternate, spiniferous; those of the upper series smaller than those of the lower, rounded, with a central eminence bearing a large, movable spine, sometimes with a group of small spinules around its base. The plates of the lower series may bear one or two large spines surrounded by spinules. There are no odd interradial marginal plates.

Large double-pectinate pedicellariæ are normally present on the interactinal plates or over their sutures in the adults, but may be partly or wholly lacking in the young. Similar pedicellarix of smaller size and fewer valves may occur on the marginal and dorsal plates; rarely on the adambulacral plates.

The larger interactinal compound pedicellarix may have ten to twelve or more ineurved papillæ on each side, while those of the dorsal surface have usually three to six. The central dorsal pore is very evident and is surrounded by papillæ. The adambulacral plates have a salient inner angle, and bear a horizontal divergent group of slender furrow-spines and a transverse actinal row of long spines, two, three, or more; rareiy one.

\footnotetext{
1 See pages 84,85 , above, for these terms.
} 
The jaw-plates are large and bear marginal and actinal series of slender spines.

The bilobed papularia often form a rather diffuse group on the basal part of the ray and on the disk; the two halves are separated by the median row of plates between which papulæ do not often occur. The papularia are not swollen. In the adult the papulæ may be very numerous; few in the young.

The dorsal muscular bands, in the few species examined, are attached proximally to a crest-like process of two ambulacral plates, as well as to the inferomarginals. Professor Fisher thinks this is a constant generic character. Other than this there are no definite or precise characters to distinguish this genus from Cheiraster. It may eventually be necessary to reunite them, under Cheiraster.

Personally I have not seen any West Indian species that can be referred with certainty to Luidiaster.

The description of the genus is given here mainly for the sake of comparison with Cheiraster and Pectinaster, but also because one of the above species ( $P$. vincenti) has been referred to it by Ludwig.

The new species, Cheiraster enoplus, described above, has the outward appearance of Luidiaster, and may eventually prove to belong to that genus, when its dorsal muscles can be studied. At present it is better to leave it in Cheiraster, for it has all the external characters of the latter.

\section{Suborder Paxillosa (Perrier, emended).}

Perrier (as an order), Exped. Traiv., pp. 28, 192, 1894. Verrill, Trans. Conn. Acad., x, pp. 199, 200, 201, 1899 ; op. cit., 1914a, p. 314 . Fisher, $1911 b$, p. 19.

These are Phanerozona in which the two rows of marginal plates are usually well developed and often spinose, (in Luidia only the lower are well developed). They usually have well marked fasciolated grooves between them, to convey water for respiration. The dorsal or abactinal plates are usually developed in the form of true, columnar paxillæ or spinopaxillæ; sometimes as parapaxillæ or pseudopaxillæ. Pedicellariæ are often present, usually consisting of several connivent papillæ, 
or spinule-like structures, on a plate, often surrounding a pit or pore. Sometimes two-bladed forceps-like forms occur.

Bivalve valvular pedicellaria are lacking. Ambulacral feet are generally pointed; sometimes flattened and natatory; rarely with a small terminal knob, but without a sucker.

Ambulacral ampullæ are usually double; single in Luidia, Ctenodiscus and allies. Dorsal pore present or absent. Superambulacral plates are usually present; sometimes absent.

The Paxillosa should only include such groups as do not have true bivalve pedicellariæ nor sucker-feet. The existence of true paxilliform plates on the dorsal surface cannot be made an invariable diagnostic character, for they occur in some forms of Valvulosa. The development of the ambulacral feet varies much in both groups, and probably depends more on the nature of the bottom anciently inhabited, than on the habits of existing species.

The gonads are commonly a single pair in the proximal part of the rays, but in Luidia and several deep-sea genera of Astropectinidæ there is a series along each side of each ray, (multiple gonads.)

The papulæ are confined strictly to the dorsal surface and often to limited or definite radial areas. They are generally simple and stand singly between the dorsal paxillæ, protected by the fascioles. In Luidia they become branched.

In Leptychaster antarcticus the eggs and developing young are carried between the dorsal paxillæ, and the young, of some size are attached to the dorsal surface. Some genera are known to undergo a complete metamorphosis, having free swimming larval stages (brachiolaria, ete.) The embryology of most of the genera is unknown.

\section{Family Astropectinide (restricted.)}

Astropectinidce (pars) Gray, Ann. and Mag. Nat. Hist., p. 140, 1840; Synopsis, p. 2, 1866. Sladen (pars), Voy. Challenger, xxx, p. 174, 1889 (includes Luidia). Perrier, op. cit., 1894, p. 193 (pars.)

Astropectinina Sladen, op. cit., 1889, p. 175.

Astropectinidee (sense ext.) Fisher, op. cit., 1911b, p. 37, (Analytical table of all recognized genera). Verrill, op. cit., 1914a, p. 314.

Paxillosa in which the disk is usually small or of moderate size. The rays are often much elongated. The dorsal surface is 
generally covered with highly developed true paxillæ (sometimes with parapaxillæ or pseudopaxillæ), covering fasciolated interspaces, lodging intervening simple papulæ.

Marginal plates of both rows are usually large, thick, and paired. The inferomarginals are often the larger transversely. They are either granulated or spinulose and often very spinose, with more or less simple fasciolated grooves between them, but never covered by a thick skin. Adambulacral plates are usually spinose or spinulose on the actinal surface and have a divergent row of furrow-spines, without a web.

Pedicellariæ are often lacking; when present they are usually fasciculate or papilliform, often consisting of two to four short, slender, connivent spinules, surrounding a special pore or pit. Ambulacral feet in two rows, large, usually pointed, never with suckers. Ampullæ double. Dorsal glands and pore usually present. Superomarginal plates always present.

Interactinal plates sometimes wanting; often more or less numerous and arranged in regular rows; usually spinulose and with fasciolated grooves between the rows, but without marginal webs; fascioles are sometimes lacking.

The aproctous condition, formerly supposed to be characteristic of the family, is unreliable, for in nearly all the genera referred to it there is a perfectly well defined dorsal or "anal" pore, and in some of the genera the pore is even elevated on the summit of a dorsal cone or chimney (Psilaster, Ilyaster, etc.) This pore, which I have designated as "pseudanus" or "nephridial pore," serves in this family (and in many others) chiefly if not entirely, for the discharge of the secretions of the lobulated dorsal gland (probably nephridial in function.)

Genus Astropecten Gray (emended).

Astropecten (pars) Gray, Ann. and Mag. Nat. Hist., vol. vii, p. 180, 1840;

Synopsis, p. 3, 1866. Müll. and Troseh., Syst. Aster., p. 67, 1842.

Sladen, op. cit., 1889, p. 193. Fisher, op. cit., 1911b, p. 55. Verrill, op. cit., $1914 a$, p. 317.

Stellaria Nardo, Oken's Isis, p. 716, 1834, (non Müller, 1832, Mollusca).

Asterias L. Agassiz, Prod., p. 191, 1835.

Rays more or less elongated, subacute, flat above, with true, abactinal, coronate or stellate paxillæ, and large, stout, paired and fasciolated marginal plates. The superomarginals are con- 
vex, encroaching more or less on the upper side of the disk and rays. They are often entirely granulose, sometimes spinulose, and often have one or two superior spines or tubercles. Inferomarginals spinulose and spinose, prolonged actinally, most of them reaching the adambulacral plates, but one or two interradial pairs may not reach the adambulacral plates, and in that case one or two pairs of small adoral interactinal ossicles may intervene, but these do not form regular rows, nor an important triangular area.*

The inferomarginals bear marginal spines and are closely spinulose and fasciolated laterally. Adambulacral plates are equal in number to the inferomarginals; the inner end is angular. They have a longitudinal group of about three, rarely four, furrow-spines, and two transverse rows, or a divergent group, on the actinal side, often with the central or aboral spine enlarged. The papulæ stand singly around the dorsal paxillæ; they are generally absent along the median line. Dorsal pore often indistinct or lacking; sometimes present. Superambulacral plates are well developed. Pedicellariæ are generally lacking; sometimes they are present on the adambulacral plates, and then are papilliform, with two, three or more valves. They sometimes occur also on the dorsal paxillæ and on the superomarginal plates.

The madreporic plate is commonly concealed by the dorsal paxilla; in some species it is exposed.

Species of Astropecten are very numerous and have been found in all tropical and warm-temperate seas in suitable localities. They live mostly on sandy or muddy bottoms, in rather sheltered localities, when in very shallow water, but on the open sea bottoms when in water deep enough to be beyond the active action of the waves.

They customarily live buried just beneath the surface of the sand, keeping up a free communication with the water for respiration by means of currents drawn through the fasciolated grooves by ciliary action. But they can also live exposed, and can glide along quite rapidly by means of their large, muscular, ambulacral feet.

They are most numerous in depths of 10 to 60 fathoms, but

* Certain species having a notable group of interactinal plates were made a separate genus, Astropectinides, by me (1914a, p. 321). 
are often found in 100 to 200 fathoms. Very few species are found at great depths. The Challenger Expedition took only three species in depths greater than 350 fathoms. The deepest was in 450 fathoms. The Albatross, in the Pacific off Panama, apparently took one species, A. exiguus, in 2,136 meters (Ludwig), but there is some doubt as to the correctness of the label. It also occurred in much shallower water. The West Indian species, so far as known, all occur in less than 150 fathoms, and most of them in very shallow water.

The species of Astropecten are apt to be variable in many of their characters, regarded as specific, and therefore their synonymy is often complex. The number and size of the superomarginal spines are variable, not only with age, but independently of it. Species that normally have spines may sometimes occur without them. These spines are often undeveloped in the young, when of considerable size, when they would appear later. The different rays of the same specimen may differ as to the size, number, or partial absence of spines.

Variations in the inferomarginal spines are also frequent, both as to size and shape. All of our species except A. braziliensis normally have two to a plate, but three spines often occur on some plates in certain species. None have more than three, as do some foreign species. Dorsal paxillæ vary considerably, in some species, but in general are fairly constant.

Perhaps the most constant specific characters are to be found in the spines of the adambulacral plates, yet these vary to some extent.

Our West Indian species have three spines in the furrow-series and nearly all have two unequal, usually flattened, spines in the second (middle) series, with the aboral one larger. But a few of our species have two or three slender and nearly equal ones in that row.

This is, perhaps, the most available character for dividing them into two principal groups (see table below).

The West Indian species, like most others, are mostly destitute of pedicellariæ, or have one or two rarely, but $A$. americanus often has a nearly continuous series, of rather large size, on the adambulacral plates. The same is true of some specimens referred to $A$. nitidus $v$, under the varietal name forcipatus. 
Other specimens, almost identical in other respects, lack the pedicellarix, or have very few.

The most distinct or most divergent species in our fauna, is A. americanus, a form exceedingly abundant off the middle Atlantic coast of the United States, in 40 to 150 fathoms.

This not only has abundant pedicellariæ, but it is peculiar in many other ways. The dorsal paxillæ have unusually long slender spinules; the marginal plates are spinulose, instead of being granulose, as in most species and the adambulacral spines are all slender, a feature not found in most species. The superomarginal plates are concave transversely in the middle and thickened near the margins, a peculiarity not found in any other species known to me.

In the West Indian fauna there are now recognized eleven species, besides two or three named subspecific or varietal forms and two or three doubtful or insufficiently described species.

The character of the superomarginal spines, although a conspicuous feature is too variable to be of primary importance in grouping the species. Moreover, if classified by this as a primary feature, closely related or even varietal forms may be widely separated, and very diverse, species brought together. The following lists may, however, be of some use in the approximate location of adult specimens.

A. Species having two rows of spines on the superomarginal plates at least proximally: A. duplicatus; A. antillensis; $A$. braziliensis.

B. Species having one row of superomarginal spines or tubercles; rows often incomplete: $A$. articulatus; $A$. alligator; A. nuttingii.

C. Species having no superomarginal spines or tubercles: A. comptus Ver., nov.; A. americanus Ver.; A. americanus subgracilis Ver., nov; $A$. richardii Perrier; $A$. cingulatus Sladen; A. articulatus dubius (Gray); A. nitidus Ver., nov.; A. nitidus forcipatus Ver., nov.; $A$. ciliatus Grube.

Analytical Table of West Indian Species of Astropecten.

A. Adambulacral plates have one or two notably enlarged spines in the second row. Few or no pedicellariæ.

B. Superomarginal plates have, in the adult, one or two rows of spines. 
C. Superomarginal plates have only one row of spines.

D. Dorsal marginal spines small, placed on the outer curvature of the plates, most developed distally, seldom reaching the second basal plate. Superomarginal plates large and thick, well rounded above, closely granulated. Fasciolated grooves wide. Adambulacral spines mostly fiattened; the two in the second series much at and mostly spatulate or trimcate, aboral and much the larger; those of furrow-series compressed, elongated.

A. articulatus (Say).

DD. Dorsal marginal spines largest on the first two basal plates, which are larger and higher than the next plates.

A. duplicatus Gray (Young).

CC. Superomarginal plates have two rows of spines proximally.

E. Inferomarginal spines mostly two or three to a plate. Superomarginal plates not unusually numerous, about 20-30, large, advancing considerably on the disk and rays; basal ones broad and swollen above surface with close, short granules. Paxallar area not very wide, about twice width of marginal plates. Inferomarginals project laterally notably beyond upper plates and have two marginal spines. Rays of moderate length. Dorsal paxillæ crowded, not forming regular transverse rows.

F. Inner adambulacral spines large and stout, compressed; two in median row very unequal; aboral and large and stout, flat, trimcate. Dorsal paxillæ coronate, with short clanate or capitate spinules; central ones similar.

F. Paxillar area bears many spinopaxillæ.

Var. variabilis (Ltk.)

FF. Inner adambulacral spines three, all slender, divergent; two in second series unequal; aboral one obtuse, large and stout, not very flat nor spatulate. Dorsal paxillæ stellate, with the spinules slender and acute; central one erect.

A. antillensis Lütk.

EE. Inferomarginal spines mostly one on each plate. Superomarginal plates unusually numerous, (48-50), proximal ones high, narrow and angular above, proximal ones not notably enlarged; surface with spinules or elongated spaced granules, distinctly larger and longer around bases of spines; fasciolated grooves deep and narrow; spines of proximal plates elongated, 
acute. Disk rather wide; paxillar area at base of rays wide, about four times as wide as the narrow marginal plates; the paxillæ are small and even, regularly arranged in transverse rows on rays; their spinules are clavate or capitate. Inferomarginals scarcely project beyond upper ones laterally; their marginal spines long and acute. Inner adambulacral spines long, rather slender; two in second row very unequal; aboral one notably large and stout, not flat, subacute or obtuse.

A. braziliensis M. and Tros.

BB. Superomarginal plates in adults are destitute of marginal spines or tubercles.

G. Superomarginal plates in adult are unusually numerous, (46-48) much higher than long, large, rectangular, evenly rounded, vertically, compactly granulated, separated by narrow fasciolated grooves; proximal pairs larger, more convex. Paxillar area wide, proximally about three times as wide as marginal plate. Paxillæ small and even, coronate, crowded, not in obvious rows; their spinules are short, eapitate numerous. Inferomarginal plates do not project laterally beyond upper ones; marginal spines are large, mostly acute. Adambulacral spines are numerous, nearly all flat, often forming four rows of about three each; three in second row are flat and truncate; two aboral little larger, subequal.

A. comptus, sp. nov.

GG. Superomarginal plates not unusually numerous, usually less than 25; large, encroaching on the upper surface.

H. Superomarginal plates not unusually broad, about 25 to 30 , granulated, not more than about half as wide as the paxillar area, proximally; fasciolated grooves wide and deep. Marginal spines of inferomarginals stout and flattened. Adambulacral spines, strong, flattened; two in second series, truncate, unequal.

h. Dorsal paxillæ do not form obvious transverse rows on the rays; their spinules are subequal, short, capitate or granule-like. A. articulatus dubius (Gray).

$h \hbar$. Dorsal paxillæ form regular transverse rows on the rays; their spinules are numerous and unequal, the central ones larger, so that the outlines of the paxillæ are defined.

A. richardi Perrier.

HH. Superomarginal plates about 19, large, unusually broad, the breadth exceeding the length; proximally about as wide as 
the narrow paxillar area, or wider, compactly granulated. Inferomarginal spines two, small, slender, acute; lower side of plates covered with short, flat spinules, and with an aboral series of small spines. Adambulacral spines small, triseriate.

A. cingulatus Sladen.

AA. Adambulacral spines of second row not notably enlarged, nor very unequal; all rather slender; one sometimes longer.

I. Superomarginal plates have a row of small spines, at least proximally, in adult.

J. Adambulacral spines few and slender; superomarginal spines confined to the proximal plates; outer surface of plates granulated.

A. alligator Perrier.

JJ. Adambulacral spines triseriate, in three regular rows of three each; all slender; outer ones very slender. Superomarginal spines form a continuous row to tip of rays, slender, acute; the plates are narrow and high, covered with elongated granules or short spinules. Inferomarginal plates project beyond the upper ones; the two marginal spines are slender, acute; lower surface covered with small spines of various sizes, not limited to two rows, and with smail acute spinules between them.

A. nuttingi Ver., nov.

II. Superomarginal plates are destitute of spines or tubercles. Dorsal paxillæ form transverse rows on the rays: Inner adambulacral spines slender, three distally, often four proximally. Pedicellariæ often present.

K. Superomarginal plates transversely convex and closely granulated. Dorsal paxillæ form transverse rows and have short capitate or clavate stellate spinules. Inferomarginal plates have two slender, acute spines, or often three proximally; lower surface with two irregular rows of small acute spines and covered with minute, slender, acute spinules.

L. Adambulacral plates have proximally three to five rather long, slender spines in inner series; three to five more slender in a row in second series; and usually three or four still more slender in outer series. Few or no pedicellariæ on adambulacral plates.

A. nitidus Verrill, nov. Typical.

LL. Adambulacral plates have, at least in part, a large pedicellaria, usually with three slender valves, on the actinal side, re- 
placing part or all of the spines of the second, or sometimes the third, series. Other characters as in typical nitidus.

A nitidus, var. forcipatus Verrill, nov.

KK. Superomarginal plates are flattish or even a little concave transversely, and covered with small spaced spinules. Dorsal paxillæ small, high, openly arranged in spaced rows; their spinules are few, long and very slender. Inferomarginal plates project laterally beyond upper ones, and have two slender, very acute marginal spines, sometimes with a small pedicellaria above the base of each; under side covered with numerous slender, acute spines and spinules of various sizes, the spines not limited to two rows. Inner adambulacral spines very slender, mostly three, but often four or five proximally; second series has four or five slender spines or else a large, usually three-valved pedicellaria replacing most or all of the spines; third series has about three or four slender spines and sometimes a pedicellaria.

A. americanus Verrill.

$k k^{\prime}$ Disk smaller; rays more slender; paxillæ smaller; adambulacral pericellariæ larger, more often four-valved.

Var. subgracilis Ver., nov.

KKK. Inferomarginal spines two, flattened, with about three small spines below base. Adambulacral spines eight on actinal face, sometimes one longer on the center. Marginal plates 40-42.

A. ciliatus Grube.

Astropecten articulatus (Say) Müll. and Trosch.

Asterias articulatiss Say, Journ. Acad. Nat. Sci., Philad., vol. v, p. 141, 1825. Astropecten articulatus Müll. and Trosch., Syst. Aster., p. 72, 1842. Lütken, Vidensk. Meddel., 1864, pp. 128, 129 (description). Verrill, Notes on Radiata, Trans. Conn. Acad., i, p. 343, 1868 (distribution); Radiata of North Carolina, p. 438. Perrier, Revision, Arch. Zoöl. Exper. et Gen., vol. v, p. 290, 1876 (not described). A. Agassiz, North American Starfishes, p. 114, pl. 19, figs. 1-8, 1877 (details of structure.) Verrill, Expl. by the Albatross in 1883, pp. 40, 77, 1885; Distribution of Echinoderms, p. 133, 1895. Ives, Echinoderms Bahania Islands, Proc. Philad. Acad. Sci. for 1891, p. 337, pl. xvi, figs. 4-8 (includes a translation of Lütken's description.) Clark, Echinoderms of Jamaica, p. [4], 1898.

Astropecten dubius Gray, op. cit., 1840, p. 182; Synopsis, p. 4, 1866 (variety).

Diagnosis: This common species, in its normal adult form, has a rather thick disk and robust rays, with large, thick, stout 
superomarginal plates, which are evenly rounded vertically, densely granulated, and separated by deep and wide fasciolated grooves, clothed with innumerable fine spinules. On the distal half to three-fourths of the ray these plates bear, on the outer convex surface, a single small obtuse-conical spine. These spines rarely extend to the base of the ray. Paxillar spinules are crowded and capitate or clavate.

Inferomarginal plates bear two flattened, short, marginal spines, side by side, and a row of about four on the under side, near each margin, the aboral ones larger; between these the surface is closely crowded with small, flat, more or less scale-like spinules.

The adambulacral spines are triseriate or nearly so; inner ones are usually three, somewhat flattened; the next row has two flat spines, side by side, the aboral one larger. Sometimes there is a third spine; outer ones are four to six, small, flat, or spatulate spinules, either in one or two rows, or clustered.

Special description: A well grown normal specimen agreeing well with Say's type, is from Egmont Key, W. Florida (No. 2213, Yale Mus.).

Its radii are $17^{\mathrm{mm}}$ and $76^{\mathrm{mm}}$; ratio, $1: 4.5$; breadth of rays at base, without spines, $20^{\mathrm{mm}}$ with spines, $25^{\mathrm{mm}}$; breadth of paxillary area at second pair of superomarginal plates, $10^{\mathrm{mm}}$; breadth at 10th pair, $8^{\mathrm{mm}}$; radius of disk is equal to first six or six and onehalf marginal plates; height of second marginal plate is equal to length (radial) of three ( $2 \mathrm{~d}$ to $4 \mathrm{th}$ ). Number of marginal plates, 27-28 pairs.

The rays are thick and stout with rather blunt tips. The ocular plate is relatively large, turned up, short and thick, as wide as long, deeply bilobed, and grooved above with the sides swollen. Paxillary area broad, even.

The superomarginal plates are larger, and thick, well rounded transversely, not at all obliquely placed, except slightly near tip of rays. The first or interradial pairs are thicker and higher than the following, and wedge-shaped.

A single imperfect row of small, short, obtuse-conic or acornshaped spines is present on the distal two-thirds or three-fourths of the ray, extending on some of the rays to the fifth plate from the base, and to the last pair of plates at the tip of the ray. 
These small spines are situated on the outer or descending curvature of the plate. Small, regular, rounded, closely-packed granules cover the rest of the outer surfaces of the plates, but the sides in the fasciolated furrows are densely covered with very slender, elongated spinules, much finer than the granules. The grooves between the plates are wide and deep.

The dorsal paxillar area is nearly even. The paxillæ are closely packed, stellate; those along the middle are quite as large as the lateral ones. Each of the larger ones bears about six to eight divergent, marginal, short, clavate or capitate spinules, surrounding one, or sometimes two, of the same size and form. At the very center of the disk there is a small area of much smaller and finer paxillæ, on a slight elevation.

The madreporic plate is partially visible, closely surrounded by the normal paxillæ; it is not far from the marginal plates.

The inferomarginal plates bear two nearly equal, stout, slightly curved, marginal spines, side by side. On the proximal half of the ray these are much flattened, lanceolate or oblong lanceolate with rather acute tips; those in the interradial angle are shorter and flatter; those beyond the middle of the ray are less flattened and more acute. The longest are scarcely equal in length to the radial length of two of the adjacent superomarginal plates.

Extending downward from the outer of these spines, and bordering the aboral margin of the plates there is a spaced row of about five smaller, flattened, usually appressed, acute spines; the upper one, close to the base of the marginal, is about half as long as the latter; the others decrease gradually in size. Another less marked row of similar but smaller spines borders the adoral margin of these plates. The rest of the outer surface is closely covered with small, flat, blunt, mostly short, scale-like, imbricated spinules. These are often as wide as long.

The adambulacral plates, when well developed, have a furrow series of three rather stout, flat, truncate, divergent spinules; toward the mouth there are often four spines. These are nearly equal in size, but the middle one is slightly longer and vertically compressed, and is seated on the slightly prominent angle of the plate. The others are thin and slightly wider near the distal end. Back of these, on the actinal side, are two flat, truncated, 
unequal spines side by side; the larger one is on the aboral side of the plate, and similar in form to the outer of the furrowspines, but somewhat larger; the smaller one is more spatulate at the tip, and not quite so long. The outer end of the plate bear's a marginal group of five to seven, most often six, small, spatulate, divergent spines, which often form a stellate group, but in other states of preservation seem rather to form two radial rows of about three each, not very regularly placed. Rarely a short ovate pedicellaria replaces part of these spinules.

The peroral spines are numerous and rather stout; epioral are very numerous and crowded, small, spatulate and flat at the tip. Color of the dry specimen yellowish brown. The colors, in life, are variable. It is often orange. It may be purplish on the paxillar area, orange-red on the superomarginal plates, with the marginal spines purple, and lower surface yellow.

\section{Variations.}

This is known to be a variable species. The superomarginal plates vary in prominence and size, and their small conical spines may be reduced to tubercles, and disappear irregularly on more or less of the distal plates, or even be entirely lacking. In other cases they extend to the interradial plates.

The marginal spines of the inferomarginal plates may be less flattened, and more acute than in the one described above, especially on young specimens. The flat, scale-like spinules of their lower surface may be less flat and more slender. The inner adambulacral spines, in the young, may be much more slender and less flattened, and the same is true of the outer ones. Pedicellariæ, of rather small size, occur rarely.

The young. A young specimen from off St. Martine Reef, West Florida (No. 16,322 , U. S. N. Mus.) with the radii $10^{\mathrm{mm}}$ and $30^{\mathrm{mm}}$ has all the essential characters of the adult, but the small dorsal marginal spinules are not developed on the first five or six plates. Center of disk has a low cone.

A still younger specimen (No. 16,324, U. S. N. Mus.) from Cape Romanes, Fla., has most of the characters of the adult. Its small dorsal marginal spines extend, on most of the rays, to the fourth proximal plate.

There is a central conical elevation of the disk, with a minute 
dorsal pore at the apex. Radii $9^{\mathrm{mm}}$ and $28^{\mathrm{mm}}$, marginal plates 17-18 on a side.

\section{Teratology.}

A medium sized specimen taken on the Great Bahama Bank by the Bahama Expedition, May 17, is quite unlike any other that I have seen, in some respects. The radii are $14^{\mathrm{mm}}$ and $53^{\mathrm{mm}}$; breadth of rays at base, minus spines, $15^{\mathrm{mm}}$; breadth of paxillar area at $2 \mathrm{~d}$ marginal plate, $4^{\mathrm{mm}}$. Number of superomarginal plates 17 to 18 pairs. The marginal plates are unusually large and thick, well rounded, rising up considerably above the narrow paxillar area and separated by wide, straight, fasciolated grooves. The radius of the disk is equal to five marginal plates. The two interradials are particularly large and swollen, except in one interradius where they are narrower and separated partially by an unpaircd intercalated plate, bearing a small conical spine. Small conjeal spines are present on the outer side of more or less of the plates on the distal part of the rays, but are entirely lacking on some distal plates, but they extend proximally in some cases to the second plate and on one side of one ray to the first plate, which bears also a second similar spine at the summit. A few other short spines of the inner series occur on the first and second plates, thus approaching the condition seen in A. duplicatus, but these spines are few, small, and irregular on this specimen. The inferomarginal spines are flattened, as in the type, mostly two, but proximally three, subequal, on many plates.

The spinulation of the under side, including the adambulacral plates, is essentially the same as in the typical specimen of $A$. articulatus, described above.

Mr. Ives (op. cit., 1891) stated that the species described by Lütken and that figured by A. Agassiz, as $A$. articulatus, are different, and that the latter represents $A$. duplicatus Gray.

I do not agree with either of these propositions. The general figures by Agassiz accurately represent the species found on the coasts of North Carolina and Florida, when in perfect preservation, and agree entirely in all essential points with the descriptions by Say and Lütken, even to the row of small conical superomarginal spines on the distal part of the rays only - a characteristic feature mentioned both by Say and Lütken. 
When picked up on the beaches, or when poorly preserved, its appearance is much altered, aside from its ordinary variations, which are considerable.

On the other hand, the A. duplicatus of Gray, as determined by Perrier, after an examination of the types, is the same as A. variabilis Lütken. It is characterized by the presence of a double row of superomarginal spines, largest proximally, and is, in fact, the most spinose species of the West Indian fauna, and therefore quite unlike the figure by Agassiz.

For the same reason reference of Gray's (well named) $A$. dubius to A. duplicatus is evidently wrong, for Gray placed it in his group having no superomarginal spines. It may well be merely the not uncommon variety of $A$. articulatus in which the small superomarginal spines are obsolete or undeveloped.

Perrier stated, 1875, that he had examined cotypes of Lütken's species. He also states that in some of his specimens the upper marginal plates were entirely destitute of spines.

This species is common on sandy bottoms, in shallow waters, on the southeastern coasts of the United States, from Beaufort, N. C., to the Florida Keys, and on the western coast of Florida, north to Egmont Key and Tampa Bay.

It has been stated by A. Agassiz that it has been found on the coast of southern New Jersey, but I have seen none from that district. It needs confirmation. It ranges to Yucatan (Ives), and from the Bahamas to the Lesser Antilles. Dominica I. (A. H. Verrill). Many West Indian localities are doubtful because several authors have confused this with other species. Kingston Harbor, Jamaica, near Port Royal, in very shallow water on sandy bottoms, near or among mangroves (H. L. Clark). West Florida, near St. Martine Reef (U. S. Nat. Mus.).

Taken by the U. S. Fish Commission, at several stations off the Carolina coasts and Cape Hatteras, as far north as $35^{\circ} 42^{\prime} \mathrm{N}$. lat. It occurred there in 4 to 43 fathoms, 1883 to 1885 . Also off W. Florida, 27 to 88 fathoms.

It was taken by the Bahama Expedition, on the Great Bahama Bank, in shallow water. The Yale Museum has specimens from Egmont Key, W. Florida (W. T. Coons, No. 2213). 


\section{Astropecten articulatus dubius (Gray).}

Astropecten dubius Gray, Ann. and Mag. Nat. Hist., vol. vi, p. 182, 1840;

Synopsis, p. 4, 1866.

Gray gave a very brief diagnosis of his species. He placed it in a section of the genus destitute of spines on the superomarginal plates. Otherwise he only states that the marginal plates are rather broad and granulated; the inferomarginals do not project beyond the upper ones, and their marginal spines are broad and depressed; the rays are broad and tapering.

These characters, so far as they go, all apply to the form of $A$. articulatus which lacks superomarginal spines.

Perrier places dubius as a synonym of articulatus without comment. He does not say whether he had seen the type, but he mentions spineless examples of $A$. articulatus, as others have done, and such as I have personally examined. Therefore, I propose to retain the name dubius for this form or variety of articulatus. It agrees with the latter in all respects, except in lacking the small dorsal spines.

It has apparently the same range as the typical form. I have seen specimens from Florida and the Bahamas.

\section{Astropecten duplicatus Gray.}

Astropecten duplicatus Gray, Ann. and Mag. Nat. Hist., vol. vi, p. 185, 1840; Synopsis, p. 3, 1866. Perrier, Arch. Zoöl. Exper. et Gen., vol. v, p. 271,1876 (no description.)

Astropecten valenciennii Müll. and Trosch., Syst. Aster., p. 68, 1842, (t. Perrier, from type.)

Astropecten variabilis Lütken, op. cit., 1859, p. 51, described. Verrill, op. cit., 1867, p. 343 . A. Agassiz, Bull. Mus. Comp. Zoöl., i, 1869 (not described.)

Plate $\mathrm{xvi}$; figures 2, 2a. Details of variety variabilis.

Plate xxii ; figure 2. Plate xxiii ; figures 1, 2.

This is the most spinose species of the genus found in the West Indian fauna. The only good description published is that by Lütken, 1859, which is in Danish, except a brief Latin diagnosis. That of Gray is an imperfect diagnosis, three lines long, not sufficient to distinguish it from several other species. It has never been figured, so far as I know, although it is a common 
species. Hence there is considerable confusion as to the names. Perrier stated (1876) that he had examined the types of Gray and of Müller and Troschel, and a cotype, sent by Lütken, of his variabilis, and had found them all identical. Therefore the name given by Gray must be adopted. But Perrier gave no description of the species, except a translation of part of that of Müller and Troschel.

Special description: A well-grown specimen, before me, seems to be the fully developed and normal form of this species. It is

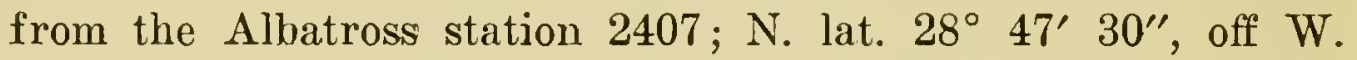
Florida, in 24 fathoms. (No. 10989, Nat. Mus.)

The radii are $14^{\mathrm{mm}}$ and $74^{\mathrm{mm}}$; ratio, $1: 5.3$; breadth of rays at $2 \mathrm{~d}$ marginal plate, without spines, $15^{\mathrm{mm}}$; radius of disk is equal to the radial length of five and a half basal marginal plates. Superomarginal plates are large and high; 25 on each radial margin.

The rays are angular, regularly tapered to narrow tips, high on the sides at base. The inferomarginal plates project, on the sides of the rays, beyond the upper ones, forming, with the lower ends of the latter, a lateral fasciolated furrow, covered with fine spinules.

The superomarginal plates are thick vertically with the outer side rising rather steeply, and the top, especially the first two pairs, prominent above the paxillar area. On the first seven plates there is a short, stout, tapered, acute spine, seated on the top of the plate and thus forming a short inner row. These spines are larger on the first two plates, decreasing to small short spines on the seventh.

An outer series of similar spines commences on the third plate and extends to the end of the ray, decreasing regularly. The surface of the plates is closely covered with short rounded granules, larger around the base of the spine, and grading into fine, short, crowded spinules in the fasciolated grooves, which are narrow and beyond the middle of the rays, distinctly oblique.

The inferomarginal plates bear two, or often three, rather short, flattened, subacute or acuminate spines; on the lower side there is along each margin a row of three or four unequal, flat, somewhat appressed spines, and between them the surface is covered thickly with rather coarse, elongated, somewhat flat and 
mostly blunt spinules, which are not appressed. Thus the lower surface appears unusually rough and spinose.

The adambulacral plates bear an inner group of three compressed, rather slender spines on the prominent inner angle; the median one, which stands farther in, is curved and larger than the others. Outside of these there are two very unequal spines, nearly side by side; the adoral one is large, stout, a little flattened, subtruncate, and much longer than the other, which is usually flat and slightly spatulate. Sometimes a second small one stands by its side. External to these there is a row of three or four slender spinules. There is a small group of three or four small, spinulated, interactinal plates.

The dorsal paxillæ are rather large, regularly stellate, and when the spinules are extended they interlock and cover the surface closely, but the spinules are often folded up in a compact fascicle, exposing the large papular pores. Their spinules are rather long, clavate or capitate; about eight to ten marginal ones surround one, or less frequently two or three central spinules of about the same form and size, or a trifle larger, but not spiniform. At the bases of the rays and on the adjacent parts of the disk they become larger, and many have four to eight central clavate spinules and twelve to sixteen around the margin. The radial paxillæ do not form regular transverse rows, but about ten to twelve can be counted across the ray proximally. They are as large along the middle of the rays as laterally. A few very small ones surround the minute dorsal pore.

Madreporic plate is nearly concealed by the paxillæ. Ocular plate is narrower, longer, less swollen, and less deeply bilobed than in $A$. articulatus.

\section{Variations.}

This species is decidedly variable, as shown by Lütken, and well deserves the name he gave it.

A well-grown specimen from Florida (No. 259, Yale Mus.) otherwise normal, is peculiar as to its dorsal spines. On some of the rays several of the proximal plates carry three or four small spines, and in one case the first plate has six such spines, while its mate has only three. On some of the other rays both have but one spine. These additional spines have mostly been produced 
by the enlargement of the larger granules that ordinarily surround the bases of the spines, and may be due to repair of injuries.

Inferomarginal plates have, in part, three acute marginal spines; there are about ten acute spines on the under side, and the intervening spinules are slender and semierect, not flattened. Radii $11^{\mathrm{mm}}$ and $60^{\mathrm{mm}}$. Marginal plates 26 on a side. Madreporic plate is partly visible. No pedicellariæ.

According to Lütken's diagnosis the essential characters of $A$. variabilis are as follows:

Radii $11^{\mathrm{mm}}$ and $52^{\mathrm{mm}}$; ratio, $1: 4.7$; breadth of ray, $13^{\mathrm{mm}}$.

Superomarginal plates large, with large biseriate or triseriate spines, often two or three to a plate. On the proximal plates of the rays there are commonly three large ones.

Inferomarginal plates are covered with somewhat large flattened secondary spines and spinules. Adambulacral spines triseriate; those of the inner row three, compressed; two in the middle row, of which the aboral one is larger and compressed; outer or third series minute.

On plate xxiii I have figured two specimens from St. Thomas I., sent by Professor Lütken, as cotypes of his species, called $A$. variabilis. They differ considerably in the characters of the dorsal paxillæ and the marginal spines, though they agree in general appearance and in most other respects. When compared with ordinary Florida specimens of $A$. duplicatus the rays appear narrower, the marginal plates higher, and their spines larger, while the paxillar areas appear narrower and more sunken below the level of the marginal plates, yet in most details of structure they agree very well.

These two specimens, although from the same place, differ widely in the structure of the dorsal paxillæ and in some other respects, so that they might well be considered local varieties if found in different localities. They may have come from different environments or different depths, not indicated on the labels. These and other variations were noticed by Lütken.

The specimen figured on pl. xxiii, figure 1, is nearly like the more ordinary or normal form described above. It has radii $11^{\mathrm{mm}}$ and $50^{\mathrm{mm}}$. The disk and radial paxillary areas are narrower than in the other. The paxillæ mostly lack a central enlarged 
spine, and have the form of ordinary paxillæ, the central spinule being short, clavate, like the rest, unless a trifle larger.

The surrounding stellate spinules are shorter than in the other, clavate, with blunt tips, so that the paxillæ appear smaller. On some parts of the rays they are arranged in evident transverse rows, toward each margin.

The inferomarginal spines are smaller and not so much enlarged or flattened. The secondary spines and the spinules of the under side are nearly the same in both, as are the adambulacral spines.

This specimen may be considered as representing the common or more typical form of the species.

\section{Variety VARIABILIS (Lütken).}

The specimen figured on pl. xxiii, fig. 2 , and of which the structural details are figured on pl. xvi, figures $2,2 a$, differs so much from the typical form that it may well receive a varietal name. This I propose to give by restricting Lütken's name to this form, which is one of those that he particularly described.

The radii are $11^{\mathrm{mm}}$ and $48^{\mathrm{mm}}$.

The superomarginal spines are large, flattened and expanded distally and subtruncated or obtusely lanceolate. Most of the proximal plates have three spines, two larger of nearly equal size, and an adoral smaller one; other plates have two, subequal or quite unequal; distally they are pretty regularly two and subequal.

In this specimen the narrow radial paxillary area is covered with rather large spinopaxillæ, which are nearly equal on the rays, but become small and crowded on the center of the disk. The larger ones, on the proximal part of the rays, have the central spinule subconical, rather stout, blunt, mostly as long as the diameter of the paxilla; sometimes there are two; those next the margin and on the distal part of the rays have the spinule more slender; toward the tips of the rays, the spines disappear and the paxillæ are of the ordinary kind and very small. The spinules of the larger paxillæ around the central spine are long, not very slender, blunt, divergent, not all in the same plane, so that they make rather large openly stellate forms, with the slender 
rays interlocking; the marginal spinules are usually ten to twelve on the larger paxillæ.

The under side of the inferomarginal plates has numerous sharp, unequal secondary spines in two rows, and between these numerous graded, rather acute, small subappressed spinules.

The secondary spines on the under side of the inferomarginal plates are of various sizes and acute; the surface spinules are small, subappressed, not very acute.

The adambulacral spines are well shown on plate xvi, fig. $2 a$, in their usual state. Sometimes there are two small spines on the adoral side of the large spine of the actinal face; sometimes the two are more unequal than in the figure.

The special feature on which this variety is based is the presence of numerous well developed spinopaxillæ on the dorsal surface.

\section{Comparative Characters.}

The most prominent features for the recognition of this species are the following:

A. The presence of two incomplete rows of short spines on the superomarginal plates, the two rows overlapping on the proximal part of the ray; and the enlargement of the first pair of plates and spines. These characters are also found in $A$. antillensis and $\boldsymbol{A}$. braziliensis.

B. The decided projection of the outer ends of the inferior marginal plates, along the sides of rays, beyond the outline of the upper plates, thus forming a sort of shelf, with a lateral fasciolated lane above it. This character was even mentioned by Gray (1840).

C. The large size of one of the adambulacral spines of the second series, but less so than in $A$. articulatus. Other characters of these spines, quite as important, need more careful scrutiny.

D. The large size and flattened or lanceolate form of the inferomarginal spines, which stand two or three on a plate, the proximal one larger; and the very spinulose condition of the under side of these plates.

According to the description of Müller and Troschel, their type of A. valenciennii had three ranges of adambulacral spines; 
the most interior contained three slender spines; the second consisted of one large compressed spine and a small one adorally placed; the external range contained three small truncated spines equal to the smaller one of the second range. It seems to be the typical form of duplicatus.

The young: Two very young specimens, taken by the Albatross, off West Florida, in 28 fathoms, are of interest. The smaller has the radii $3^{\mathrm{mm}}$ and $8^{\mathrm{mm}}$; the other $4^{\mathrm{mm}}$ and $12.5^{\mathrm{mm}}$ with 12 marginal plates in each series.

The latter has already developed the most obvious specific characters, so that one would not hesitate as to its identification. The first pair of interradial superomarginal plates are already enlarged and each bears an upright conical spine as long as the radial breadth of the plate. Enlarged granules are present on some of the following plates in the places where additional spines would have appeared.

The inferomarginal spines already have their flattened linearlanceolate form, though small. There is a prominent conical elevation in the middle of the disk of both, covered by minute paxillæ, and terminated by a very small apical pore.

The adambulacral spines and jaw-spines are like those of larger specimens, but in miniature.

The smaller specimen has ten marginal plates. No superomarginal spines have developed, but clusters of coarser granules on the first interradial plates show where they were about to form. The inferomarginal spines are more slender, but yet are somewhat flattened. The podia are relatively very large, flattened, acute.

This species is common and widely distributed in shallow water all through the West Indies, and in the Gulf of Mexico, and north to Florida.

Gray's type was from St. Vincent; that of Müller and Troschel was from Vera Cruz; those of Lütken were from St. Thomas, S. Cruz, and Florida. Perrier records it from North Carolina, but that needs confirmation. I have never seen it from so far north. In the Yale Museum there are specimens from the Florida Keys (No. 259) and also from the west coast of Florida, at Egmont Key, near Tampa Bay (E. Jewett coll., No. 1768). The Albatross dredged it off West Florida, N. lat. $26^{\circ} 18^{\prime} 30^{\prime \prime}$ and N. 
lat. $28^{\circ} 47^{\prime} 30^{\prime \prime}$ in 24 and 27 fathoms. Jamaica (Clark); Dominica I. (coll. A. H. Verrill).

Astropecten antillensis Lütken.

Astropecten antillensis Lütken, Vidensk. Moddelels., 1859, p. 47. Verrill, op. cit., p. 343, 1867. Perrier, Revision, op. cit., p. 282, 1876 (deseription.)

According to Lütken's original diagnosis his types had the following characters :

Dorsal marginal spines biserial in the adult; the inner series varies in number, largest near the proximal angle of the ray. Inferomarginal spines two, slender; the ventral side of these plates is covered with slender spines. Adambulacral spines sixbiseriate, median ones larger; outer median one flattened. His specimens varied from $22^{\mathrm{mm}}$ to $115^{\mathrm{mm}}$ in diameter.

Perrier states that the inferomarginal plates are sparsely covered with small, scale-like spinules, and also have a row, transverse to the ray, of larger secondary spines. The adambulacral plates bear two rows of spines, about five in each, the middle spine in each being somewhat larger.

It is very closely allied to $A$. duplicatus, and may prove to be only a local variety of that variable species. To determine this needs a larger series than I have seen. It is also closely related to $A$. braziliensis, but apparently less so than to $A$. duplicatus.

From the latter it differs in having more slender and not so flat marginal spines; more slender secondary spines and spinules on the inferomarginals, and in the more slender adambulacral spines, which appear to be more numerous, more slender, and arranged in two rows; the larger spine of the second row is not so much enlarged as in the related species.

According to Perrier, this species becomes $120^{\mathrm{mm}}$ in diameter. In his larger example all the superomarginal plates have one spine; on the first two plates it is on the upper margin; on those further out it is placed nearer the outer margin; some proximal plates have a second small or rudimentary spine on the inner margin, in line with those on the two interradial plates, thus showing a tendeney to form two rows.

Perrier, from an examination of the types, considered $A$. braziliensis distinct from this. He states that the latter differs in 
having only thirty marginal plates while braziliensis has fifty, of which those on the basal half of the ray bear two spines, but these are shorter and less acute; the former has, on the rays, paxillæ with a small central spinule and six marginal ones, increasing to eight on the disk, without change in character, while on A. braziliensis the radial paxillæ have eight to twelve marginal paxillæ and often two or three central ones, and on the disk they become crowded and granule-like, placed in concentric circles, losing their stellate character, and forming groups of twenty or more. Other differences are found in the adambulacral armature.

In antillensis there are two rows of adambulacral spines each with five or six, nearly equal, except the central one, which is a little larger, while in braziliensis there is an inner row with the middle one compressed, curved, and a little larger, and just behind this is one large, aboral, conical, pointed spine, having alongside of it, adorally, two others, not more than half as large; and still further back some irregularly placed small spinules (usually three or four).

He states that the inferomarginal plates are covered in both species with scales (flattened spinules), but in braziliensis they are more numerous, forming a uniform covering, but they are only appressed, not imbricated. In antillensis these spinules are more sparse and scattered.

St. Thomas (Lütken). Guadeloupe (Perrier).

\section{Astropecten braziliensis Müll. and Trosch.}

Astropecten braziliensis Müll. and Trosch. Syst. Ast., p. 68, 1842. Duj. et Hupé, op. cit., p. 415, 1862. Verrill, op. cit., 1864, p. 343. Perrier, Revision, op. cit., pp. 284, 288, 1876. R. Rathbun, op. cit., p. 150, 1879. Sladen, op. cit., 1889, pp. 194-198 (no description).

A large characteristic specimen, from Rio de Janeiro (Coll. C. F. Hartt, No. 5,204, Yale Mus.), has long, regularly tapered, acute rays, with a narrow angulated border of marginal plates, bearing proximally two rows of acute spines, the first on each side decidedly longer and larger, marginal spines, of the lower series, are long and acute, only one large one on a plate.

The radii are $16^{\mathrm{mm}}$ and $96^{\mathrm{mm}}$, ratio, $1: 6$; breadth of ray at base, minus spines, $17^{\mathrm{mm}}$, of paxillar area, at second pair of 
plates, $12^{\mathrm{mm}}$; radius of disk equals the length of first nine marginal plates; number of superomarginal plates is $48-50$, on a side.

The superomarginal plates proximally are high, angular, short and narrow, about as long as wide above, and encroaching but little on the paxillar area, so that the border of plates is narrow. Distally these plates become relatively wider, and more rounded, with the sutures oblique. The outer lateral faces of the proximal plates are nearly vertical. The first three or four plates are much compressed and short.

The inner row of dorsal spines continues only to about the ninth or tenth plate, decreasing rapidly in length to the last, which is a mere tubercle; the first is a stout, terete, acute spine, about $3^{\mathrm{mm}}$ high.

The outer row of spines usually begins on the third or fourth plate and extends nearly to the tip of the rays. These are small, conical, acute, gradually decreasing from the proximal to the distal ones. The upper surface of the plates is covered with elongated spaced granules, or granule-like spinules, largest around the bases of the spines. On the outer surface they become much smaller, like fine short spinules, and grade into the longer and more slender fasciolar spinules in the sutural grooves, which are wide and deep.

The inferomarginal plates scarcely project laterally beyond the upper ones, with subtruncate ends. They have only one large marginal spine, which is rather long, somewhat flattened, tapered or acuminate, and usually very acute. The longer ones are $3^{\mathrm{mm}}$ long, or equal to the length of three adjacent dorsal plates. Proximally many of the plates have no secondary marginal spine; others have, on the adoral side, a sinall acute spine not more than a fourth or a third as large. Distally the adoral spine becomes relatively larger and more

On the ventral side these plates have a transverse row of smaller acute spines along each margin, usually five or six in each, the outer one largest, just at the bases of the marginal spines. Elsewhere the surface is covered with small, semierect, flat, blunt or truncate spinules, not closely appressed, but semierect.

The adambulacral plates have furrow-series of three long, 
rather slender spines, slightly flattened; the central one longer and somewhat compressed. The second series consists of a very large and stout, tapered, obtusely pointed aboral spine, with one or two much smaller, slender, spatulate ones on the adoral side; when there are two, one stands behind the other. They are scarcely half as long as the large one. The outer row is pretty regular and formed by three to five small spatulate spines.

The dorsal paxillar area is rather wide, nearly even, densely covered with small coronate paxillæ whose outlines are mostly easily visible. On the rays the paxillæ form irregular transverse rows, except along the median band, where they are larger and crowded. The smaller ones on the rays have eight to ten marginal spimules around one or two granule-like, larger central ones.

The larger ones may have twelve to sixteen marginal spinules and three to six in the middle. On the disk most of the paxillæ are larger; they may have sixteen to twenty-four small marginal spinules surrounding a central rosette of slightly larger capitate ones, consisting of six to nine, in a circle, surrounding one or two in the center. The spinules are all short and capitate or clavate.

The madreporic plate is large and plainly visible, surrounded by a circle of the larger regular paxillæ, with only one row of them separating it from the marginal plate.

The ocular plate is unusually small and narrow, bilobed by a deep median groove. According to Perrier (op. eit., 1876, p. 284) the dorsal radial paxillæ have eight to twelve marginal stellate spinules with two or three central ones, but on the disk the spinules become more numerous and crowded, about twenty on a plate arranged in circles, and so reduced in length as to appear like granules, showing only their hemispherical ends, due to the crowding.

The superomarginal plates bear two rather short spines on the proximal half at least. These spines may be $1^{\mathrm{mm}}$ high.

The inferomarginals are almost entirely covered beneath with small flattened or scale-like, appressed spinules, which are not imbricated; near the transverse sutures these scale like spinules give place to four or five elongated, flattened, acute spines, increasing toward the upper margin, near which there is between 
the two rows a long flat acute spine nearly as long as the breadth of the plate, so that this margin seems to bear three spines, instead of the two marginals found in $A$. antillensis.

The adambulacral plates have an inner marginal series of three spines, in which the median is larger than the others, recurved, and flattened; on the actinal side there is a median, large, conical, acute spine, and two others, at one side, about half as long; exterior to these are other small spines, in a row or irregularly placed.

Off Bahia, Brazil, 7 to 20 fathoms, and at Fernando Noronha (Sladen). Bay of Rio de Janeiro, common, (C. F. Hartt; R. Rathbun).

Sladen (1859) in his analytical table, puts this down as having three inferomarginal spines. This appears to be due to the presence of two secondary spines, belonging to the two central rows, standing one on each side, and a little below, the single large marginal spine. When the second true marginal spine, of smaller size, appears it is on the same level or a little above the large spine and on the adoral edge of the plate.

This is the only species from the West Atlantic, known to me, that has, normally or commonly, only one true inferomarginal spine. This is, therefore, a good diagnostic character. Various foreign species have a single spine, normally.

Another good diagnostic character is the openly subspinulose covering of the superomarginal plates, while all the otherwise similar species have them closely granulated.

\section{Astropecten comptus Verrill, sp. nov.}

Plate xii; figures 3-3c. Details. Type. Plate xxii; figure 1. Type.

Rays rather stout, elongated; the largest adult has about 48 to 50 spineless, evenly granulated, transversely rectangular superomarginal plates, proximally about one-third as wide as the width of paxillar area of the ray, and encroaching on the upper side so as to form a conspicuous and somewhat raised border.

Radii of the largest specimen, $18^{\mathrm{mm}}$ and $95^{\mathrm{mm}}$; ratio, $1: 5.3$; breadth of ray at base, minus spines, $19^{\mathrm{mm}}$; breadth of paxillar area, $11^{\mathrm{mm}}$ at second plate. Radii of the type specimen (No. 
8,514) figured, $13^{\mathrm{mm}}$ and $58^{\mathrm{mm}}$; ratio, $1: 5.2$; marginal plates 38.

The superomarginal plates are broadly and evenly rounded, transversely rectangular, with the sutures straight and transverse to the ray, narrow, closely fasciolated. They are closely covered with short even granules, often polygonal, due to crowding; they grade regular into the minute, short fasciolar spinules.

The dorsal paxillar area has a nearly even surface, slightly areolated by the outlines of the small paxillæ. The latter are coronate, much crowded, not forming obvious transverse rows on the rays; they have a central rosette, of about five or six short capitate spinules or granules, surrounding one in the middle, and a marginal series of numerous small ones. The median radial paxillæ are as large as the lateral ones; those of the disk rather larger, with more spinules in the central rosette.

The inferomarginal plates scarcely project laterally beyond the upper ones; they have two moderately large and long, somewhat flattened and curved, acute marginal spines. The larger proximal ones are about as long as two marginal plates. The under side of these plates is covered with minute slender, suberect spinules and has a transverse low of small, acute spines near each margin, four to six in each, the aboral ones the larger.

The adambulacral plates have an inner series of three rather long flattened spines, the median one a little longer and vertically compressed; the median series has two, or sometimes three, sribequal, flattened, subspatulate or truncate spines, the aboral one slightly longer and larger; exterior to these are commonly two rows, with three each, of smaller, flat, truncated spinules, but these, on some plates, often form a divergent group of five or six around a central spine. No pedicellariæ were found on the type specimens. The largest specimen (No. 18,346, Nat. Mus.) is from off W. Florida, in 26 fathoms. No. 8,514 is from Albatross station 2,286, off Cape Hatteras, in 11 fathoms.

\section{Astropecten richardi Per.}

Astropecten richardi Perrier, Revision, op. cit., p. 292, 1876.

Radii of the type $18^{\mathrm{mm}}$ and $73^{\mathrm{mm}}$; ratio, $1: 4$. Rays slightly constricted at the base. Superomarginal plates are 22 to 25 on each side of each ray.

The superomarginals are rectangular, nearly twice as broad 
as long, slightly convex, separated by a groove, spineless, and covered nearly uniformly and closely with small hemispherical granules, becoming spinuliform in the sutural grooves.

Dorsal paxillæ are pretty fine, close, and form transverse series laterally, but are irregular on the median third of the ray and on the disk. Those of the rays have three or four central granules, or short spinules, and eight to ten marginal ones. On the disk the paxilliform marginal spinules are much more numerous and finer than the central ones, which may be ten to twelve, so that their outlines are well defined by this inequality.

The inferomarginals have two large upper spines, up to $4^{\mathrm{mm}}$ long, cylindric or flattened, not tapered, with a smaller spine at their bases. Their sutural grooves are bordered with regular spinules, near which is a regular row of six or seven spaced, elongated, slender, pointed spinules, arising from small notches in the plate. The spines are longer distally. There are also similar spinules on the free border and on the border next the adambulacrals. (Condensed from Perrier.)

The adambulacral plates have an inner marginal row of three divergent spines, the middle one longest; the actinal surface has two larger spines, one behind the other, the outer one often smaller or replaced by several spinules.

The type was from Cayenne, French Guiana. This appears to be very closely allied to $A$, articulatus, var. dubius. I have not seen the type.

\section{Astropecten cingulatus Sladen.}

Astropecten cingulatus Sladen, Voy. Challenger, Zoölogy, vol. xxx, p. 218; pl. xxxv, figs. 5, 6; pl. xxxix, figs. 1-3 (enlarged, details), 1889.

The rays are unusually short, with about 19 broad marginal plates, wider than high. The type had the radii $9^{\mathrm{mm}}$ and $28^{\mathrm{mm}}$; ratio, $1: 3.1$.

The superomarginal plates are large and broad, at middle of ray wider than the narrow paxillar area. They therefore form a wide border to the rays; surface elosely granulose.

The inferomarginal plates have two short, nearly terete, slender acute equal spines, with smaller acute spines at their bases and an aboral series of small acute spines beneath. The under side is covered with small, short, appressed spinules. 
Adambulacral plates triseriate; inner row of three slender unequal; second series of two or three, short, truncate, subequal. (Condensed, from Sladen.)

Easily distinguished by the broad marginal plates and small acute lateral spines. Taken by the Challenger, off Pernambuco, Brazil, between 32 and 400 fathoms (special station record lost).

Astropecten nitmus Verrill, sp. nov.

Plate $\mathrm{xx}$; figure 2. Type.

Regularly stellate with rather short acute rays and a prominent and wide border of spineless granulated plates.

Radii of the largest specimen (No. 18,344) are $11^{\mathrm{mm}}$ and $41^{\mathrm{mm}}$; ratio, $1: 3.7$; breadth of rays at base, minus spines, $12^{\mathrm{mm}}$; breadth of paxillar area, at second plate, $5^{\mathrm{mm}}$. The radius of the disk is equal to the length of seven proximal dorsal plates.

The superomarginal plates are wide, evenly convex, with deep, directly transverse, sutural grooves. The first plate is enlarged above, wedge-shaped, and larger than the next. The proximal plates are rectangular, the width of the third plate is equal to three times its length; distally they become nearly square. They are closely covered with small, short, rounded or polygonal granules.

The dorsal paxillar area is narrow, less than twice the width of the adjacent marginal plate at the base of the rays. The paxillæ are not very small and form pretty obvious transverse rows on the rays; those along the middle band are as large as the others. Their spinules are regularly stellate, small, clavate, about 10 to 15 on the larger ones, around the margin, surround one or two central spinules of the same size. Those on the disk are similar in size, except at a very small raised central area, where they become very small and crowded. The madreporic plate is partly visible, small, convex, separated from the marginal plates by about three rows of paxillæ.

The ocular plate is small, broader than long, deeply bilobed, strongly upturned.

The inferomarginal plates do not project beyond the upper ones; they bear two moderately long, tapered, acute, subequal spines. Their under side is covered with fine, acute, suberect spinules and two transverse rows of small acute spines. 
The adambulacral plates have three slender spines in the inner row, the middle one longer, larger, and compressed; sometimes there are four or five spines proximally, on a few plates. The second row usually has about three smaller and more slender subequal spines; the third row has three to five still smaller ones; a fourth row of three small spinules is sometimes present. Sometimes the spinules of the outer part form a divergent group of eight or nine.

A papillose pedicellaria often replaces the spines of the second series on more or less of the plates in variety forcipatus.

Young specimens, with the greater radius $13^{\mathrm{mm}}$ to $16^{\mathrm{mm}}$ have essentially the same characters.

Dredged by the Albatross off West Florida, at station 2,318, in 45 fathoms; station 2,836, in 111 fathoms; station 2,406, in 26 fathoms; and off Georgia, station 2,417, in 95 fathoms (variety); station 2,418, in 95 fathoms; station 2,313, in 99 fathoms (variety). The largest specimen (described above) is from station 2,762. (No. 18,344.) Range in depth, 20 to 111 fathoms.

AstropeCten Nitidus var. Forcipatus, nov.

Plate xvi; figure 3. Details. Plate $x x$; figure 1. Type.

This form agrees with the preceding in size, shape, and nearly all other respects, except the armature of the adambulacral plates.

In this a large, blunt, conical pedicellaria, with three to five slender valves, replaces all or most of the spines of the second series. It it usually near the aboral edge of the plate, and in that case there may be one or two small spines on the adoral edge. But it is frequently on the middle of the plate with no spine alongside. Two may occur on one plate, side by side.

These pedicellariæ may occur on nearly every plate, or they may be absent on part of them. The four or five slender outer spines are usually present with the pedicellaria.

Similar pedicellariæ occur on the few interactinal plates and sometimes a few of smaller size are on the inferomarginal plates.

Taken off South Carolina and Georgia by the Albatross, in 95 and 99 fathoms (Nos. 10,067 and 10,543); and off W. Florida, in 26 fathoms. 


\section{Astropecten alligator Pertier.}

Astropecten alligator Perrier, op. eit., 1881b, p. 30; Etoiles de Mer, p. 270, 1884.

According to Perrier the essential characters of the type are as follows:

Radii $9^{\mathrm{mm}}$ and $40^{\mathrm{mm}}$; ratio, $1: 4.5$; breadth of ray at base, $9^{\mathrm{mm}}$. Superomarginal plates are thirty on each side of a ray.

The disk and rays are flat; rays acute. The inferomarginal plates project laterally beyond the upper ones.

The superomarginal plates are little elevated, almost square; interradial ones broader than long. They are covered with pretty coarse, prominent, spaced granules. Three or four proximal plates bear each a single, pretty short, conical spine, on the middle of the interior border; that on the triangular first plate is largest; those farther out become nearer to the exterior side.

The inferomarginal plates have two flat and acute marginal spines; underneath they have a row of about three smaller flat spines along the aboral margin; the rest of the surface is covered with acute scale-like spinules, among which are some larger obtuse, flat spinules.

The adambulacral plates have a furrow-series of three divergent spines; one or two smaller ones are placed on the lateral margins, and three on its exterior margin. Sometimes there is also a central spine on the plate.

The paxillar area, at the base of the rays, is about equal to four times the breadth of the marginals. The paxillæ are small; they have six to eight slightly clavate spinules surrounding a group of central ones. They form pretty evident transverse rows of about fifteen, proximally, on the rays. Off Alligator Key, Florida, in 147 fathoms. ${ }^{26}$ I have not studied the type.

Astropecten nuttingi Verrill, sp. nov.

Plate xii; figures 2-2e. Details. Plate $x x i$; figures 1-2. Type.

A regularly stellate species, rather thin vertically. The disk is usually rather flat, and often has a central conical elevation.

26 Perrier (1884) gave the depth as 147 feet. There is no such depth given in the original lists of dredgings off Alligator Reef, but there is one of 147 fathoms (No. $194 \mathrm{P}$ ). Probably there was an error in transeribing the label. 
Radii of one of the larger are $10^{\mathrm{mm}}$ and $44^{\mathrm{mm}}$; ratio, $1: 4.4$. Another has them $10^{\mathrm{mm}}$ and $38^{\mathrm{mm}}$; ratio, $1: 3.8$. Another, $8^{\mathrm{mm}}$ and $32^{\mathrm{mm}}$; ratio, $1: 4$. The margin is narrow and not very thick, owing to the smallness of the marginal plates. The dorsal paxillar area is relatively wide.

The paxillæ are small, nearly equal and even, regularly stellate, arranged in obliquely transverse rows. Two rows usually correspond to each superomarginal. In the proximal interradial region there may be ten paxillæ in a row from the margin to the median radial line; opposite the eighth pair of plates there are about six; toward the tips of the rays the rows are indistinct. The larger proximal paxillæ may have eight to ten spinules around the margin and one, or less often two, in the center. At about the middle of the rays the larger ones have six to eight marginal and a single small central one. The spinules are slender, not very long, obtuse, or slightly capitate, all nearly equal. The paxillar columns are rather high and slender, with round or elliptical convex tops. They are in close contact by their bases along the median line, but elsewhere have isolated papular pores between them.

The superomarginal plates are rather small, higher than long, proximally, with the outer side nearly vertical and the upper end narrow but prominent. Their sutures are deep and finely fascioled. There are about thirty-two plates on each side of a ray, in the larger specimens.

The superomarginal plates are regularly covered with small, short and very slender spaced spinules, usually as fine and sometimes finer than those of the dorsal paxillæ; those in the lateral fascioles are still finer and very numerous. Each plate usually bears a small, rather short, tapered, acute spine on the most convex part of the upper side; these are larger proximally, gradually decreasing distally, and becoming very small on disappearing toward the tips of the rays. They are usually in a very regular row, but some are often lacking and sometimes there is a smaller one (sometimes two) close beside the larger one.

The inferomarginal plates correspond in number and length with the upper ones Their fascioled suture are deep and somewhat oblique proximally, becoming decidedly oblique distally. These plates are prolonged to the adambulacrals and are but little 
convex. Their outer surface is well covered with small, unequal, acute spines, which form about three or four irregular rows, transverse to the rays. These spines, at the middle of the row, may be as long as the radial breadth of the plate. There may be six to eight or more in a row. The upper ones, two or three in number, are larger and longer and stand at the base of the two large spines that stand on the superior margin of the plate, side by side. These are a little curved, often somewhat flattened, tapered and acute, those on about the eighth to tenth plates are somewhat the larger. In length they about equal the radial breadth of two plates, and are more than twice as long as the longest upper marginal spines.

Interactinal plates are very small and few, in the interradial areas. They are spinulated and some of them usually bear papilliform pedicellariæ.

The adambulacral plates proximally have a marginal row of three slender acute spines, of which the median is a little the longest and largest, and occupies the apex of the angular margin; it is a little curved and usually compressed. On the actinal surface of the larger subproximal plates, there are usually four or five similar, slender spines (three or four more distally). These may stand nearly in two rows, but normally three or four stand on the border of the plate and one, slightly larger, stands nearer the center, so that, as preserved, they often form a substellate group ; but more often they appear irregular and crossed, due to contraction or pressure. Sometimes four or more of these spinules converge and form a fasciculate pedicellaria, especially on the jaws, but these are often absent or very few.

The madreporic plates is small and nearly concealed by the paxillæ. A minute dorsal pore appears to be present at the summit of the central cone.

It was taken by the Bahama Expedition at station 64, off American Shoal, Fla., in 110 fathoms (five specimens, including the type) ; stations 56, 57, 58, Pourtales Plateau, in 200 to 225 fathoms (several, one specimen is rather thicker and more spinose than the type.) Station 28, off Florida, 116 fathoms, one young. It was taken by the Albatross, at station 2,418, in 90 fathoms, off Georgia, N. lat. $33^{\circ} 20^{\prime}$ (No. 18,350).

This species appears to be closely allied to $A$. alligator Per- 
rier. The description of the latter is not sufficiently precise, and in respect to the adambulacral spines, it is somewhat ambiguous. The description, so far as it goes, would indicate that it is a distinct species, but a reëxamination of the type is necessary in order to determine this with certainty.

\section{Astropecten americanus Verrill.}

Archaster americanus Verrill, Amer. Journ. Sei., vol, xx, p. 402, 1880; Expl. by Albatross in 1883, p. 542, 1885.

Astropecten americanus Verrill, Proc. Nat. Mus., vol. xvii, p. 255, 1894;

Distribution New Eng. Echinod., p. 133, 189j.

\section{Plate xvi; figures $1-1 a$}

The body is decidedly flat and thimner than in most species. Rays long, slender, tapering to rather acute tips.

The type had the radii $12^{\mathrm{mm}}$ and $74^{\mathrm{mm}}$; ratio, $1: 6.16$. It becomes considerably larger than this, with the larger radius up to $85^{\mathrm{mm}}$ or more. Ratios vary from $1: 5.25$ to $1: 6.25$. The radius of the disk is equal to the length of the first eight marginal plates.

Among several thousands, a few were found with six and some with four regular rays.

The dorsal paxillary area is rather wide; at the base of the rays it is about four times as wide as the opposite plate. The paxillæ are small, with a slender elevated column, and a divergent group of six to ten or more very slender elongated spinules, surrounding one or two central ones of similar size and form. They form narrow transverse rows on the rays. The rows are openly spaced so that the rather large and numerous papular pores can usually be seen. There is a narrow median band destitute of papulæ, where the paxillæ do not stand in rows.

The superomarginal plates are relatively small and numerous (40 to 50 or more), becoming very small toward the acute tips of the rays. At the base of the rays their width is about onefourth that of the paxillar area. They are rectangular proximally, broader than long, with nearly straight, deep and wide, transverse, densely fasciolated grooves; distally they become nearly square, with slightly oblique sutures. Proximally the outer and upper surface is usually transversely flat or distinctly concave, owing to the presence of a thickened margin next the 
sutures. They do not rise much above the paxillar area, nor encroach much upon it, but yet form a regular raised border.

Their outer surfaces are covered with very small, acute, spaced spinules; at the sutures these change rather abruptly into the longer closely fasciolated spinules. Nearly always there are no traces of spines or tubercles on these plates, but very rarely a small conical spine occurs on one to three of the proximal plates, but with no regularity nor constancy.

The inferomarginal plates project laterally a little beyond the upper ones; their lower side is flattened, and usually a little thickened at the aboral margin. They bear two slender, elongated, slightly flattened and very acute marginal spines; just above the base of each there is sometimes a small papilliform pedicellaria. The under side is covered with suberect, very acute, small, spaced spinules and small spines of various sizes; the larger ones form an aboral submarginal row, but others occur irregularly.

Interactinal plates are few and small, next the jaws; they are spinulose and often have a central pedicellaria.

The adambulacral plates have a furrow-series, usually of three slender spines distally, but often with four or five proximally. The second and third rows, when there is no pedicellaria, usually consist each of three or four slender, nearly equal spines, the outer ones a little smaller.

Often there is a large papilliform pedicellaria, usually with three valves, which replaces all or most of the spinules of the second row; if any remain they are on the adoral side.

The valves of the pedicellariæ are usually strongly spatulate, incurved somewhat, and truncate or notched at the tip. Although most have three valves, some have four, and others have but two.

The madreporic plate is large, with deep gyri. It is usually wholly or partly exposed and separated from the marginal plates by only one or two rows of paxillæ.

The ocular plate is small, about as wide as long, deeply bilobed, and with a proximal notch.

The jaw-plates are narrow and much elevated, densely covered with small slender epioral spines, the two clusters convergent. Adoral spines similar and very numerous. Peroral spines numerous, some much thicker ones at the apex are obtuse. 
Color in life, bright light yellow to orange-yellow; sometimes pale yellow.

This species was taken in vast numbers (many thousands), at about a hundred stations, by the Fishliawk and Albatross, 1880 to 1887, during the Explorations by the U. S. Fish Commission, off the eastern coast of the United States, in 43 to 296 fathoms.

It was most abundant in 60 to 150 fathoms, where two thousand to five thousand were repeatedly taken by us in a single haul of the trawl.

It occurs abundantly from N. lat. $40^{\circ} 23^{\prime}$ to the region off the Carolina coasts. Farther south it seems to be less common, but it reaches the Florida Straits, West Florida, and the Caribbean Sea, off Colombia.

It was taken by the Albatross at station 2647, in 85 fathoms, in the Straits of Florida; at station 2399, in 196 fathoms, off West Florida. Also at station 2143, in the Caribbean Sea, north of Colombia, in $\mathbf{1 5 5}$ fathoms (variety subgracilis).

This is probably the most abundant starfish, off our coast, if we except the littoral species of Asterias.

\section{Variety SUBGraciLIS, nov.}

Rays flat, long, narrow, very slender distally and acute. Paxillar area rather narrow, paxillæ small, with about eight to twelve very slender elongated divergent spinules, which in the dry specimens are mostly grouped in a fasciculate bundle, leaving the papular pores exposed. Distally toward the tips of the rays the paxillæ become very small with almost microscopic spinules. Proximally they form spaced transverse rows, except along the median band where there are no papulæ. Some of them have a small papilliform pedicellaria replacing part of the spinules.

Madreporic plate rather large, convex, exposed. Ocular plate smaller and narrower than in the typical form.

Superomarginal plates nearly as in the ordinary form, but with fewer and more minute spinules.

Inferomarginal spines are normally two, usually unequal, the adoral smaller and sometimes absent. These spines are very slender and acute. Small pedicellariæ often occur just above their base, and also on the under side of the plate.

Adambulacral spines are all slender; inner series of three, elongated and tapered; second series of two, subequal, slender, as 
long as inner ones, but usually replaced by a large three-valved to five-valved pedicellaria, with spatulate valves. These often form a regular and continuous series.

This variety differs from the typical form mainly by having a smaller disk and more slender rays, and more slender spines and spinules, and its adambulacral pedicellariæ are larger and more fully developed than in the type-form.

Taken in the Caribbean Sea, off the northern coast of Colombia, in 155 fathoms. Albatross station 2143, No. 18,464.

Astropecten ciliatus Grube.

Astropecten ciliatus Grube, Archiv. fur Naturgeschichte, vol. xxiii, p. 340, 1857.

According to the brief diagnosis of Grube, this species belongs to the group of species which have a cluster of six to eight or more spines on the actinal face of the adambulacral plates. He mentioned no superomarginal spines. These points would make it seem related to $A$. americanus and $A$. nitidus, but otherwise it does not appear to agree with either of those species.

The type was 4.5 inches (about $108^{\mathrm{mm}}$ ) in diameter; ratios of the radii, $1: 4.5$; superomarginal plates, 45 ; inferomarginals, 42.

The superomarginal plates are evenly granulated. The inferomarginals have two large, equal, flattened spines with three shorter ones below them.

The adambulacral plates have three furrow-spines and about eight on the actinal face, of which one is longer.

Puerto Cabello, Venezuela.

Doubtful species of Astropecten.

Astropecten spatuliger Perrier.

Revision, p. 296, 1876.

Said to be from Nicaragua, but whether Atlantic or Pacific is not stated. It is much like some Pacific coast species, with broad rays and flat spines.

Genus Blakiaster Perrier.

Blakiaster Perrier, op. cit., 1881, p. 28 ; op. cit., p. 265 , 1884; op. cit., p. 242, 1894. Type, B. conicus Per. Verrill, Revision Genera, p. 218, 1899. Fisher, The Genus Blakiaster, Bull. Mus. Comp. Zoöl., vol. liv, No. 4, p. 161, pl. 1, 1911; also, op. cit., 1911b, p. 40 . Verrill, op. cit., $1914 a$, p. 322 . 
The dorsal plates are rounded, decidedly convex above, with about six basal lobes, which unite by overlapping, leaving about six simple papular pores around each plate, except on the disk, along the median row, and on a small interradial area, where papulæ are lacking and the plates are more closely joined.

The dorsal plates are protopaxillæ, bearing many small, short, divergent spinules on the convex portion, but not forming fascioles. On the disk and base of the rays there are a few small interpolated plates.

A single row of plates separates the superomarginals distally in the type. There are no well-marked fascioles between the superomarginal plates. The marginal plates are thick, convex, regularly paired, somewhat oblique distally. The superomarginals are granulated or minutely spinulated. The inferomarginals are spinulated and also, in the type, bear a few larger spines in a submarginal transverse row. Grooves between the plates are shallow and have only poorly developed fascioles.

The interactinal plates form series subparallel to the adambulacrals, but there are a few unpaired plates in the median interradial line. The interactinal plates are tesselated, somewhat convex, roundish or subpolygonal, and bear divergent spinules that do not form evident fascioles nor regular radial rows.

The adambulacral plates are somewhat oblique, with an angular inner end, which bears a row of four to six spines; the actinal surface is covered with small divergent spinules, not fasciolated.

Jaws stout and convex, covered on the actinal side with spinelets, and with a row of about nine longer spines on each side. The peroral spines, in a pair, are larger.

The pedicellariæ are small, papilliform, with three to six valves surrounding a small pit in the plate. They are often lacking. Superambulacral plates are present. A small dorsal pore was present in some of the specimens examined by me.

Professor Fisher has given (op. cit., 1911) a more detailed description of the type of this genus, with photographic figures. I have also studied the type, as well as several other specimens. No other species is known, unless Bunodaster ritteri Ver., of California, be considered congeneric, as Fisher suggested (1911b, p. 40).

Bunodaster differs from Blakiaster by its less massive and differently shaped marginal plates, which are less complex and 
have more fully developed fascioles. The lower marginals have the spines in a central row or group, not submarginal. There is no differentiated median radial series of dorsal plates; nor any notable number of secondary ossicles, so evident in Blakiaster; nor any median radial area destitute of papulæ, as in the latter. There are well defined fascioles between the adambulacral and interactinal plates, not found in the latter; and the adambulacral spines of the adoral plates are deeply sunken in the groove, as in Persephonaster, but not in Blakiaster. The abactinal plates are thinner, more regularly stellate, and more delicately articulated by the slender radial lobes than in the latter, so that the test is more flexible. No pedieellarix were found in the type of Bunodaster.

In some of these characters Bunodaster is near to Persephonaster, but the latter lacks the odd interactinal plates, found in Blakiaster and in Leptychaster.

From the latter Bunodaster differs in the characters of the dorsal plates; in the less profoundly fasciolated grooves between the marginal plates; and in other characters; but it is perhaps as nearly allied to the latter as to Blakiaster. The genus Bunodaster is certainly closely allied to Blakiaster, Persephonaster, and Leptychaster, especially to the two former.

Perrier, in his later report (1894), has united Blakiaster with Leptychaster, but it seems to me sufficiently distinct. In this genus the interactinal plates are not arranged in definite radial series, nor do they have well developed fascioles between them. On the contrary, they have a rather irregular, crowded, tesselated arrangement, the plates being roundish or polygonal, pretty closely united, without the deep, sutural, fasciolated furrows found in Leptychaster. The marginal plates, also, have only rudimentary fascioles. The jaws are stout and evenly convex, instead of thin and carinate. The dorsal plates are larger, rounded, more convex, more regular, and less paxilliform. Leptychaster does not have spines on the inferomarginal plates.

\section{Blakiaster conicus Perrier.}

Blatiaster conicus Per., 1881, p. 28; Etoiles de Mer, p. 265, pl. ix, fig. 2, 1884. Verrill, Trans. Conn. Acad. Sci., vol. x, p. 218, pl. xxvii, fig. 7, 1899.

Leptoptychaster conicus Per.. Exp. Trav. et Talism., p. 243, 1894.

Blakiaster conicus Fisher, op. cit., 1911, p. 161, p]. i; op. cit. 1911b, p. 40, note. Verrill, op. cit., $1914 a$, pp. 322, 371. 
Plate iii; figure 4. Plate xi; figure 5. Details. Plate xiii; figures 1-1c. Details.

The type of this species, in the Museum of Comp. Zoölogy, is small and doubtless quite young. Some specimens obtained later are rather larger, but none appear to be adult.

Radii of the type $10^{\mathrm{mm}}$ and $27^{\mathrm{mm}}$; ratio, $1: 2.7$; marginal plates fifteen on each ray.

The median radial row of dorsal plates is slightly differentiated, the plates having more hexagonal bases, with shorter lobes, and therefore more closely united; they have no papular pores between them; near the base of the rays they have a few smaller plates between them, and such secondary plates also occur on the disk.

The spinules of the dorsal plates are slender, rough, divergent, but not fasciolated; the central spinules are longer and stouter than the others.

The superomarginal plates are closely covered above with short or granule-like spinules, which grade into slender spinules laterally, forming rudimentary fascioles, and become longer on the lower side.

The inferomarginals are more convex or swollen; they are covered with small sharp spinules, and also bear an oblique row of two to four or more slender, acute spines, situated near the distal margin, and usually appressed, so as to be directed distally.

The proximal interactinal plates are roundish or subpolygonal, rather crowded, tesselated or overlapping by their edges, with no evident fascioles between them. They are covered with slender, acute, divergent spinules. They have about three or four divergent rows or ehevrons with one unpaired plate in each row, except the first. A single row extends on the rays, beyond the disk.

The adambulacral plates are decidedly oblique, transversely elongated proximally, with the inner end angular and projecting into the groove. There are about five slender divergent spines in a row along the angular margin. The actinal surface is covered with a divergent cluster of small, slender spinules, similar to those of the interactinal plates. About ten proximal plates 
correspond to the first pair of inferomarginals. The ambulacral feet are conical, subacute.

The jaw-plates are prominent, convex, but not much enlarged, covered with acute spinules, the apical ones stouter.

The adoral series of spines are not deeply depressed into the groove, as they are in some of the allied genera.

The pedicellarix are small and papilliform or conical. The largest are on the interactinal plates. (See pl. xiii, fig. 1c.) They have four to six small, slender, convergent valves. Those on the dorsal and marginal plates are considerably smaller with three or four valves. They sometimes occur, also, on the adambulacral plates.

For some additional details see the description and photographic plates by Fisher (op. cit., 1911).

Perrier (op. cit., 1904) united this genus to Leptychaster unnecessarily.

The two original specimens were from the Blake Exped., station 25, in 92 fathoms, off Grenada; and in 175 fathoms, off Havana.

The Bahama Expedition took it at sta. 58, in about 200 fathoms, off Florida (4 specimens), and sta. 64, in 110 fathoms, off American Shoal (4 specimens).

It was dredged by the Albatross at several stations in the West Indies, in 92 to 175 fathoms, and in the Gulf of Mexico, off Alabama, in 178 fathoms, station 2357.

\section{Genus Sideriaster Verrill.}

Sideriaster Verrill, Revision Genera, p. 219, 1899. Type, S. grandis Ver.

Form broadly stellate with a very large disk; dorsal surface convex, and capable of inflation, closely covered with uniform, stellate paxillæ. Upper marginal plates are not large, lateral in position. Interactinal areas large, with numerous plates, mostly in single radial rows, with fasciolated grooves between.

The dorsal paxillæ are large, closely arranged, and nearly uniform in size and shape, regularly stellate, with short, even spinules.

The madreporic plate is very large, round, flat, fully exposed, and has very numerous, thin, radiating gyri. 
Papular pores are very numerous and are arranged singly, about six around each plate over the whole of the disk and rays, even close to the ends.

There is no distinct dorsal pore visible, nor do the central plates differ in size from those of the disk in general.

Marginal plates are small and not prominent. The upper ones are entirely confined to the margin, and are granulated, without spines. The lower ones form the lower part of the margin, but extend also on the disk below; they bear spinules with a median row of larger spines.

Interradial actinal areas are large, with numerous plates, the distal ones extending to the distal third of the rays. They are arranged in single radial series, each series usually corresponding to an adambulacral plate and most of them to a marginal plate, but some of the series are short and do not reach the margin, there being more adambulacral than marginal plates proximally, but distally they generally correspond in number, though there are sometimes, locally, two marginals to one adambulacral. These plates are covered with granules, and have divergent, fasciolated spinules along their radial margins, thus forming fasciolated grooves that are coincident with those between the marginal plates.

The adambulacral plates have a prominent furrow-angle, on which there is a large, median, compressed spine; at each side of this there are, in the furrow-series, two or three erect flattened spines; a stout spine occurs on the center of the actinal side, with a single or double row of shorter flat spines back of it.

The jaws are large, not very prominent, covered with numerous short, blunt spinules, and have furrow-spinules like those of the adambulaeral plates.

The only known species of this genus is from the Gulf of Mexico, in 68 fathoms.

SIDERIASTER GRANDIS Verrill.

Sideriaster grandis Verrill, Revision Genera, p. 220, pl. xx, figs. 8-8b, 1899.

Plate xii; figures 5-5b. Details.

Large, regularly five-rayed, with a broad, somewhat swollen disk, regularly and broadly incurved at the sides. The rays are rather large and rapidly tapered. Greater radii, 133-138 ${ }^{\mathrm{mm}}$; lesser, $40^{\mathrm{mm}}$. Ratio, $1: 3.4$. 
The dorsal paxillæ are round and high, remarkably uniform in size, arranged on the rays in imperfect, transverse, oblique rows. They bear a round, rosette-like cluster of rather coarse, short, clavate or capitate, divergent spinules, of which one is usually central, with 6 or 7 in a circle around it, while about 15 to 18 form the marginal row, interlocking with those of the adjacent plates, so as to conceal the papular pores. The latter are rather large and regularly arranged over the whole disk and nearly to the ends of the rays, usually six around each paxilla. The bases of the paxillæ appear stellate.

The margin is formed mostly by the upper plates, which do not extend at all upon the upper side. They are small and short, those on the interradial margins shortest and highest, at least four times as high as long. They are covered with coarse, rounded granules, and bordered with fascioles of slender spinules. The lower marginals are of the same length and extend considerably on the under side. They are covered closely with sinall, appressed, flattened spinules, largest centrally, grading laterally to the marginal fasciolated spinules. On the middlc of each plate there is a vertical row of about four stout, tapered, more or less flattened, acute spines.

The madreporic plate is remarkably large and flat or slightly concave, with very numcrous and thin radiating gyri.

The interactinal plates are granulated nearly like the upper marginal plates. Other under parts have been described above under the generic deseription.

Pedicellariæ occur in small numbers on the adambulacral plates and on the first row of interactinals. They have two or three short, stout, flattened, spinuliform blades, similar in size to the adjacent spinules.

Dredged by the Albatross at station 2378, in N. lat. $29^{\circ} 14^{\prime}$ $30^{\prime \prime}$; W. long. $88^{\circ} 09^{\prime} 30^{\prime \prime}$, in 68 fathoms, in the Gulf of Mexico, off Mobile, Alabama. (No. 10877, U. S. Nat. Mus.)

\section{Sideriaster? vestitus (Say) Verrill.}

Asterias vestita Say, Journ. Philad. Acad., rol. v, p. 143, 1825.

Astropecten vestitus Lütken, op. cit., 1859, pp. 27, 54 (no description). Ver-

rill, Proc. Boston Soc. Nat. Hist., rol. x, p. 339, 1966 (no description). Sideriaster? vestitus Verrill, Ann. and Mag. Nat. Hist., rol. xir, p. 21, $1914 c$.

This has always been a doubtful species. I am not aware that 
it has been redescribed by any writer since Say, in 1825 . Lütken mentions it as probably an Astropecten, but adds nothing to its history. It is ignored by Perrier, 1876, and by nearly all later writers, except quotations by name only.

The description by Say is very incomplete. Aside from characters common to all species of Astropecten, the only points of importance that he gives are the following:

The disk is broad, rays depressed. The dorsal paxillæ have ten to eighteen small, equal, cylindrical spinules.

The marginal plates bear "about four very much compressed, subquadrate, truncated spines, which are vertically appressed to the surface of the plate, and imbricated with respect to each other." Diameter fourteen inches. Cape May, N. J. "It is very rare on this coast."

Presented to the Philadelphia Academy of Natural Sciences, by Mr. Robbins.

In Ives's more recent list of Asterioidea (1889), in the collection of the Academy, no such specimen is mentioned. Probably the type is lost. It is probably not an Astropecten.

In having a large disk, and especially in having four appressed spines in a transverse row on the inferomarginal plates, the Sideriaster grandis V. agrees, perhaps, with Say's species. But he gives too little, as to other characters, to enable us to say whether they are related. Sideriaster grandis is from the Gulf of Mexico, in 68 fathoms, off Mobile, Alabama, and therefore might, possibly, occur in deep water, off Cape May, but it is not very probable that it does, for the very numerous dredgings of the Albatross in that region brought up nothing of the kind. Nor do we know whether the four appressed spines, mentioned by Say, occupy the same places as those of Sideriaster. This comparison, therefore, is intended as a suggestion.

Perhaps the most notable thing said about $A$. vestitus is the remarkably large size. Say states that his unique specimen was one foot and two inches in diameter. This size is much greater than that of any American Astropecten seen by me or recorded by others, but is not unusual for species of Luidia. Some foreign species of Astropecten have been described of that size, however.

As Say does not mention any spines of the superomarginal 
plates (as he does in the case of $A$. articulatus, where they are very small), it is to be presumed that there were none. The existence of four peculiar, appressed, flat spines, presumably on the inferomarginal plates, is the most important character given. He does not say that any are marginal.

The locality, Cape May, southern New Jersey, is north of the usual range of $A$. articulalus, and every other littoral species of the genus, known on our coast, but $A$. americanus occurs farther north, in deep water, off the coast. The latter, however, does not agree at all with the description.

It is possible that this specimen was not really obtained at Cape May, or if so, that it may have been fished up from deep water, off that shore, by local fishermen.

It is possible, though not probable, that it was only a very large specimen of a variety of $A$. articulatus, which is a very variable species, and not infrequently lacks spines on the upper marginals.

Genus Plutonaster Sladen.

Plutonaster Sladen, Narrative Challenger Exped., vol. i, p. 610, 1885; op. cit., p. 81, 1889. Perrier, Exped. Trav. et Talisman, pp. 312-313.

Form is stellate with a broad flat disk and rapidly tapered, rather rigid rays. The marginal plates are large and thick, rather rectangular, encroaching on the upper side to form a stout border, and standing opposite the lower ones.

The marginal plates of both series are closely covered with elongated granules. They may bear short, thick spines on one or both series, or spines may be entirely lacking. Grooves are fasciolated. The dorsal area is wide and closely covered with small parapaxillæ, showing no median radial row, but often in transverse rows on the rays.

Papulæ are widely distributed, except on the interradial areas. Pedicellariæ are generally absent, when present papilliform, with three or four valves. They occur on the interactinal plates. Dorsal pore distinct.

Adambulacral plates have a regular marginal row of small spines, and on the actinal face two or more longitudinal rows of mostly short or almost granule-like spinules; sometimes one is spiniform. The interactinal plates are numerous and stand in regular rows, from the adambulacral to the inferomarginal plates. 
This is essentially a deep-sea genus. The species seldom occur in less than 300 fathoms, but are often abundant at greater depths. Some occur in 1,500 to 2,000 fathoms.

\section{Plutonaster intermedius Perrier.}

Goniopecten intermedius Perrier, op. eit., p. 25, 1881; op. cit., p. 251, pl. vii, figs. 1, 2, pl. iv, fig. 4, 1884 .

Plutonaster intermedius Perrier, Exped. Trav. et Talisman, p. 316, 1894 (redescribed).

Perrier $(1884$, p. 252) mentions several very young specimens that he thinks belong to this species, as coming from $70,103,120$, and 213 fathoms, in the Lesser Antilles. They were from 8 to $25^{\mathrm{mm}}$ in diameter. Specimens so small as that, in this genus, can seldom be identified with any certainty, unless older ones come from the same locality, to form a series.

Adults of this species occurred in 833 to 955 fathoms and deeper. Therefore I doubt the identification of these young ones. The description is brief.

I did not see them when I examined the Blake collection. They are entered here, for want of a better place, until they can be studied more fully.

It should also be remembered that a large part of the Blake starfishes (as well as those of the Albatross) were taken by tangles, and that it is not an uncommon thing for small starfishes and other organisms to be overlooked and thus left on the tangles to come up again, with a subsequent haul, perhaps from a very different depth. Thus there may well be doubt of some unusual records of single small specimens of such objects. I write this from personal experience of 20 seasons in dredging.

Family Goniopectinide Verrill, 1899, p. 213.

Stellate with elongated rays. The marginal, adambulacral and actinal plates are bordered with peculiar pectinate spinules united by a web, thus forming specialized, continuous fascioles.

Dorsal plates are paxilliform or columnar and covered with small spinules. They are arranged in oblique transverse rows on the rays.

Marginal plates large, regularly paired, the sutures corresponding above and below; sometimes they are spinose. There may be 
an odd interradial marginal plate in each series (Prionaster). Surface of the marginal plates usually smooth or with a few scattered granules, sometimes entirely granulated, usually covered with a thin membrane.

Interactinal plates form radial series, usually double, running from the adambulacral to the marginal plates, with deep fasciolated grooves between them, continuous with the fasciolated grooves between the marginal plates.

The adambulacral plates project over the ambulacral furrows, forming constrictions; they bear a curved or angular series of furrow spinules united by a basal web.

The jaws are rather large and very prominent, with an open suture. They bear two or more enlarged apical spines, and more or less numerous smaller spinules on the actinal side.

Gemus Prionaster Verrill, 1899, p. 215.

This genus differs from Goniopecten especially in having an odd interradial marginal plate, in each row, and a double series of unpaired interactinal plates corresponding to them.

For more details see the original description. The genus includes only the following species:

\section{Prionaster elegans Verrill.}

Prionaster elegans Verrill, Revision Genera, op. cit., p. 216, plate; figures 4, $4 a, 4 b, 4 c, 1899$.

Plate xii; figures $4-4 c$.

Disk small; sides high and vertical, evenly incurved; rays high and nearly square at base, tapering regularly to the slender tips.

Radii of the type, $14^{\mathrm{mm}}$ and $70^{\mathrm{mm}}$; ratio, $1: 5$.

The marginal plates are oblong and much higher than long on the disk, but gradually become squarish on the rays. The upper and lower are exactly coincident, so that the vertical sutures are continuous. Their sides are nearly perpendicular and they encroach only a short distance on the disk, but at the middle of the rays each series is about as wide as the dorsal area; distally, near the tip of the rays, they are separated only by a single row of very small paxillæ. The distal plates bear groups of small spaced granules near the upper end. Each of the upper ones, 
except on the distal third of the rays, bears a small, movable, tapered, acute spine at the upper angle; those at the base of the rays are longer than the rest.

Some of the inferomarginal plates of the rays have a similar, but smaller, spine at the lower angle and near the distal edge of the plate; most of the interradials have also a small cluster of minute granules near the lower end. All the marginal plates are bordered by a very regular and even series of small spinules webbed together to their tips. Those of the upper plates are much more numerous, finer and closer, and more evenly pectinate; they nearly touch across the grooves. Those of the lower plates stand a little apart and are more divergent, about half as many in the same space as on the upper plates, and very similar to those between the actinal plates.

The actinal areas are not large and extend to about the eighth adambulacral. The median odd series consists of two closely united rows of about six each, the distal ones becoming very small. The next series contains a row of five plates and one of three similar plates; this series corresponds to the second and third adambulacrals.

The adambulacral plates are broad and roundish, the proximal ones quite oblique; their furrow-edge projects over the furrow and bears a row of 10 to 12 small, slender, acute spinules, which are somewhat divergent and webbed together for about half their length; they meet or interlock across the furrow, leaving rounded or ovate open spaces between them for the passage of the large and tapered ambulacral feet. On the outer and lateral margins of the plates there is also a series of divergent, webbed, fasciolated spinules like those of the actinal plates.

The madreporic plate is rather large, with fine gyri. The dorsal nephridial pore is situated in the center of a low elevation composed of very small, round paxillæ.

Taken by the Albatross at station 2401, in the Gulf of Mexico, in 142 fathoms. (No. 18,428, U. S. Nat. Mus.)

For more details see the original description.

Family Luidinæ Verrill.

Luidiidxe Verrill, Trans. Conn. Acad., x, p. 201, 1899. Fisher, op. cit., 1911b, p. 105. Verrill, op. cit., p. 333, 1914a.

Luidïne (subfamily) Sladen, op. cit., pp. 175, 244, 1889. 
Disk small, covered with true paxillæ, which are usually largest at the sides of disk and rays; rays five to ten or more, long, flat, flexible in life. Superomarginal plates small, paxilliform, often indistinguishable from the dorsal paxillæ. Inferomarginals transversely elongated, large, spinose, fascioled, corresponding in number and radial length with the adambulacrals and separated from them thronghout the rays by a row of small peractinal plates.

Pedicellariæ usually present on the actinal side, forceps-like, with two or three blades, or spiniform.

Ambulacral feet large, flattened, muscular; can be used as paddles for gliding rapidly along the bottom just under the surface of sand or mud. I have observed (1901) that Luidia clathrata swims or paddles with remarkable speed, just under the surface of the sand in shallow water, and that it swims or glides actively in an aquarium, by using its feet as paddles.

The dorsal nephridial glands, or "cœeal appendages," intestine and dorsal pore are lacking. The papulæ are branched.

This family is very distinct from all others, but nearest to Astropectinida. It is well represented in the West Indies, as in most tropical and subtropical seas.

\section{Genus Luidia Forbes.}

Luidia Forbes, Wern. Trans., 1839, p. 14; Mem. Wern. Soc., viii, p. 128, 1840. Müller and Troschel, Syst. Aster., p. 77, 1842. Sladen, op. cit., p. 244, 1887. Fisher, 1911b, p. 105. Verrill, op. cit., p. 334, 1914a.

Rays five to ten, rather flat, flexible. Dorsal columnar paxillæ have lobate, articulated bases; summits either plainly paxillose or with a central spine or tubercle (spinopaxillæ), or with both kinds; largest next the lateral borders of the rays. Inferomarginal plates spinose and spinulose. Pedicellariæ often absent; when present, forceps-like, with two or three blades or valves. They are nsually situated on the adambulacral plates; sometimes on the inferomarginals or peractinals.

Inferomarginal plates are transversely elongated, with wide and deep fasciolated grooves between them, bordered by slender spinnles; central portion with one or more rows of spines. Superomarginals small, paxilliform, rounded. Adambulacral plates short, with one furrow-spine (rarely two); they are separated 
by wide grooves. The dorsal paxillæ may be quadrate at surfaee and crowded, in regular rows, or stellate. Regular rows of papulæ between the rows of paxillæ. No superambulacral plates observed.

Gonads are multiple, in rows, with separate pores along the sides of the rays. Papulæ may be branehed. Ambulaeral ampullæ are single.

Luidia Clathrata (Say) Lütken.

Asterias clathrata Say, Journ. Acad. Nat. Sci., Philad., vol. v, p. 143, 1825. Luidia clathrata Lïtken, Vidensk. Meddel., p. 37, 1859. Gray, Synopsis, p. 4, 1866. A. Agassiz, North American Starfishes, p. 117, pl. xx, 1877. (Structure.) Verrill, Notes on Radiata, Trans. Conn. Acad., vol. i, p. 271, 1867; Amer. Journ. Science, vol. iii, p. 438, 1872; ditto, vol. xlix, p. 134, 1895; Trans. Conn. Acad. Sci., vol. xi, p. 36, 1901 (habits); Starfishes of N. Pacific, pp. 7, 31, pl. 103, fig. 1, 1914a.

\section{Plate xxiv; figure 2.}

This is a large, five-rayed species, with long rays.

The dorsal pasillary area of the rays is rather flat or somewhat convex, wide, eovered with unusually large, mostly squarish, or at least quadrangular, paxillæ which form proximally, in medium sized speeimens, about ten to twelve nearly regular rows. About four or fire of the lateral rows, on each side, are deeidedly larger and more regular than the rest. The first three rows are nearly equal; the others decrease regularly in size; the two. or three median rows are the smallest and least regular. On the disk they become more erowded, and irregularly arranged ; many are hexagonal, pentagonal, or polygonal; those in the eenter are the smaller and more irregular, being about equal in size to the median ones of the rays. All the paxillæ are eovered with numerous rather eoarse, short, nearly even-topped, but unequal, spinules. On the larger lateral paxillæ there are usually from twelve to sixteen larger central spinules whieh are enlarged and rounded at the tips, and stand in rows of three or four, while the margins are bordered with numerous much smaller, slightly elavate spinules. On the smaller median paxillæ there are usually six to eight of the larger eentral spinules, surrounding one or two in the middle, thus often forming a minute rosette-form, bordered by the finer marginal spinules.

The inferomarginal plates are large; each bears two unequal, 
acute, upper marginal spines; the upper one is less than half as long as the other, which is regularly tapered, often a little curved, but not flattened and very sharp; in length, the larger ones are about equal to one-fourth of the rays proximally, or equal to the width of the three adjacent rows of paxillæ. Around the bases of the large spines are a number of small acute spines.

Color in life, either gray, or salmon, or rose-salmon.

This species, like others of the genus, habitually lives concealed just under the surface of the sand. Its presence is betrayed, in shallow water, by the star-shaped impression that it forms by the action of currents of water flowing upward, through the paxillar areas, caused by ciliary action for respiratory purposes. When disturbed it glides away very rapidly, beneath the surface of the sand, by means of its large, flattened, muscular ambulacral feet, which it uses like paddles. It can also swim, by their aid, free of the sand, or on its surface.

Most common in less than 20 fathoms. Taken at 18 stations, from N. lat. $37^{\circ} 31^{\prime}$ to $35^{\circ} 12^{\prime}$, by the U. S. Fish Commission, in 10 to 48 fathoms. Common in shallow water from North Carolina southward to Florida and the West Indies. Rio Janeiro, Brazil. Rare north of Cape Hatteras; it has been recorded from southern New Jersey.

In the Yale Museum there are specimens from Egmont Key, W. Florida, W. T. Coons (No. 2195); Fort Macon, N. C., Dr. Yarrow (No. 4431); Rio de Janeiro, coll. C. F. Hartt (No. 5202); Cuba; etc.

Bermuda, common in sheltered situations just below low-tide level, on bottoms of shell-sand, concealed just below the surface.

All living specimens seen by me in Bermuda were either pale salmon or rose-salmon. Those from Florida and North Carolina are gray.

\section{Luidia alternati (Say) Lütken.}

Asterias alternata Say, Journ. Acad. Nat. Sci. Philad., v, p. 144, 1825.

Luidia alternata Iütken, Vidensk. Meddel., p. 42, 1859; op. cit., p. 301. 1871. Verrill, Notes on Radiata, Trans. Conn. Acad., i, p. 343, 1867. Perrier, Arch. Zoöl. Exper., v. p. 254, 1876. Sladen, op. cit., 1889, p. 250. Ires. op. cit., p. 326, 1890. Nutting, Narrative, p. 166. Clark, op. cit., p. $4,1898$.

Luidia variegata Perrier, op. cit., p. 257, 1876.

Luidia gramulosa Perrier, Pedicellaires, p. 109, 1869 (t. Perrier, 1876). 
Rays five, a little swollen or depressed, long and fragile. It grows to rather large size, up to $325^{\mathrm{mm}}$ in diameter; more often about $200^{\mathrm{mm}}$.

The dorsal paxillæ are small, rounded, and have a central spinule, longer and larger than the slender stellate ones that surround it. Four of the lateral rows of paxillæ are larger and more regular than the others with a longer middle spinule; those on the median part of the rays and on the disk are smaller, with fewer spinules. Those next to the marginals may lack the larger eentral spinule.

The inferomarginal plates bear two larger, long, acute, upper marginal spines, alternating in position, so as to form two series. On the lower side the plates also bear about three larger spines in a row, and many small acute ones.

The adambulacral plates bear either three or four slender spines in a transverse row, the innermost curved and smaller than the others.

The madreporic plate is usually concealed by the paxillæ.

This is a shallow-water species found mostly in sheltered localities on sandy or muddy bottoms, often just below low tide mark. Yet it extends down to 40 fathoms, off Florida (A. Agassiz), and to 88 fathoms in the Antilles (Perrier). Florida Reefs (Say); Yucatan (Ives). Off Bahia, Brazil, in 7 to 20 fathoms (Sladen).

It ranges from the coast of Florida throughout the West Indies to Bahia, Brazil. Port Royal, Jamaica, on muddy bottom near mangroves (Clark). St. Thomas, 20 fathoms (Lütken).

It was taken by the Bahama Expedition on the Great Bahama Bank (one young and two large) and near Key West, Florida.

It has not been found at the Bermudas.

I have examined the type of Luidia variegata Per. in the Mus. Comp. Zoölogy. It is evidently the young of this species. It was from Isle Breton, off the mouth of the Mississippi River.

Color in life: olive-green or purplish with yellowish irregular bands across the rays; under side yellow (Say). According to Nutting (Narrative, p. 166) the marginal spines of the larger specimens were chocolate-brown at the base and white at the tips.

The color in life, according to Ives, is straw-color, with three or four irregular transverse bands of blackish on the dorsal surface, not extending to the under side; spines greenish; ends 
of ambulacral feet orange-red. According to Clark (1898), the color of one at Jamaica was dark olive-green or purplish above, with irregular yellowish bands across the rays; beneath yellow. Some specimens have the spines banded with lighter and darker colors.

\section{LUIDIA ALTERNATA BICOLOR, variety nov.}

\section{Plate xii ; figures 1-1c. Details.}

The dorsal area is pretty evenly covered with small spinopaxillæ, having a small acute central spine, surrounded by a circle of about nine to twelve short clavate spinules. The spinopaxillæ are in pretty regular nearly equal longitudinal rows of twelve to fourteen or more.

The marginal plates bear three long, slender, acute, terete, bicolored spines, chocolate-brown on the basal half and pale or white distally.

The longer spines are about three times as long as the adjacent plates. The lower spine is considerably smaller and shorter than the two upper ones. It arises from near the adambulacral plates, and is sometimes lacking. The large spines are all surrounded at the base by a group of slender, very acute, small spines.

The adambulacral plates bear two slender, acute spines, one behind the other. The inner one is smaller, shorter, and curved outward. These are also surrounded at their bases by a number of small and very slender spines.

This was taken by the Bahama Expedition, off Key West, Fla., at station 39 , in 20 fathoms (one large), and at station 24 , in 60 fathoms (young). I have also seen it in the Albatross collections.

\section{Luidia eleggans Perrier.}

Luidia elegans Perrier, Arch. Zoöl. Exper., vol. v, p. 256, 1876; Etoiles de Mer, p. 269, 1884. Verrill, Amer. Journal Sci., vol. xx, p. 403, 1880 ; ditto, vol. xlix, p. 134, 1895; Expl. by Albatross in 1883, p. 543, pl. xiii, figs. $39,39 a$ (distribution).

Plate xvi; figures 4, 4a. Details. Plate xix; figure 1. Young.

This species, as taken by us, grows to more than $350^{\mathrm{mm}}$ in diameter. Color, in life, deep orange above, lighter below. 
It readily detaches its rays and therefore is seldom dredged entire. It normally has five rays.

The dorsal paxillæ are stellate, much crowded, smallest in the middle of the rays; larger laterally. Each bears a circular marginal group of very slender spinules, one to three in the center, and often, in adults, one to three blunt pedicellarix.

Inferomarginal plates have, in the adults, a vertical row of three long, tapering, acute spines, the upper ones largest. In the young usually but two spines are present.

The adambulacral plates have a transverse row of three rather slender, sharp spines; the inner one smaller and recurved; the middle one largest. A row of ovate, bilabiate pedicellariæ occurs between the inferomarginal and adambulacral plates.

The type, as described by Perrier, was young; it had the radii $5^{\mathrm{mm}}$ and $35^{\mathrm{mm}}$; ratio, $1: 7$.

The inferomarginal plates are short, almost vertical, and bear two or three long, sharp spines, besides their spinules.

The dorsal paxillæ are nearly alike, becoming more complex toward the borders. Each has a rather short central spinule, surrounded by six to ten longer, spaced, marginal spinules, scarcely enlarged at the tip, and forming a simple stellate group, giving the paxillar area a very uniform appearance. Madreporic plate was concealed by the paxillæ.

On the actinal side there is a row of two-valved pedicellariæ, between the adambulacral and inferomarginal plates.

Perrier (1884) mentions a much larger specimen, with radii $12^{\mathrm{mm}}$ and $115^{\mathrm{mm}}$, and considers the presence of two-valved pedicellariæ distinctive of the species.

The Bahama Expedition took, at station 63, in 85-95 fathoms, a young specimen agreeing very closely with the type, in size and most other characters. Its radii are $5.5^{\mathrm{mm}}$ and $36^{\mathrm{mm}}$; ratio, $1: 6.54$. It has two large, nearly equal, acute spines on the marginal plates, and occasionally a third, lower down. It also has a series of small bivalve pedicellariæ external to the adambulacral plates, as in the type, so that there can scarcely be a doubt as to its identity.

It differs, however, from Perrier's description in the character of the dorsal paxillæ. Instead of being nearly uniform, they are decidedly diverse in size. The lateral row, on each side, con- 
sists of stellate, round paxillæ about twice as large as those of adjaeent rows, and these are in turn at least twice as large as those along the median region. The latter are very small, with few slender spimmles, and much crowded.

The adambulacral plates of this specimen have three rather long, acute spines in a transverse row ; the inner one, on the apex of the plate, is shorter than the others, more slender, somewhat recurved and compressed.

Large numbers of specimens, many of them of large size, were taken at about forty stations, off the eastern coast of the United States, in 1880-1887, by the United States Fish Commission steamers, mostly in 53 to 146 fathoms, from N. lat. $37^{\circ} 31^{\prime}$ to the region south of Cape Hatteras. The Albatross also took it in the West Indies.

It was taken by the Blake, off Barbados, in 200 fathoms (Perrier). The locality of the type was not given. It was from the Mus. Comp. Zoölogy, dredged in "101 feet." Perhaps from the Hassler Expedition, off Barbados.

It was taken by the Bahama Expedition at station 63, in 85-95 fathoms, off Florida (2 spec. See pl. xix, fig. 1).

\section{Luidia barbadensis Perrier.}

Luidia barbadensis Perrier, op. eit., p. 29, 1881. Etoiles de Mer, p. 267, pl. $\mathrm{x}$, figs. $7,8,1884$.

\section{Plate xxiv; figure 1.}

Rays flat above, slender, commonly six, sometimes five. The type had the radii $10^{\mathrm{mm}}$ and $125^{\mathrm{mm}}$; ratio, $1: 12.5$. Greater breadth of rays about $11^{\mathrm{mm}}$.

According to Perrier the characters of the type are as follows:

Rays six, very long and extremely fragile. The three outer rows of paxillæ, on each side, have the paxillæ larger than those of the middle region; next there are two pretty regular rows of small paxille; the median ones are still smaller and irregularly placed.

The inferomarginal plates are covered with small spines and have a median row of larger conical spines, of which the last two are considerably larger and form the marginal row of spines.

The adambulacral plates have one furrow-spine, which is com- 
pressed and slightly recurved; outside of this are two other spines equally compressed, nearly straight, and placed a little obliquely, one behind the other. Outside of these are two or three smaller and more slender spines. Some of the plates bear papilliform pedicellariæ with three valves.

The two specimens figured by Perrier (1884) have five rays. The largest one of his types, when examined by me (1896) had six broken rays. It was from station 274, off Barbados, and is probably the one described by Perrier.

It was taken by the Blake at four stations, in 40 to 209 fathoms, mostly off Barbados.

The color, in life, appears to have been red.

A specimen from the Albatross collection (No. 10,449; see pl. xxiv, fig. 1) has six rays, but all of them had been broken off near the disk and are in process of restoration, giving it the appearance of having six short, rapidly tapered and acute rays. The original parts agree very well with Perrier's types and description. Radius of the disk $10^{\mathrm{mm}}$; of the rays, as repaired, 35 to $52^{\mathrm{mm}}$.

On the repaired portions of the rays the dorsal paxillæ are smaller than on the old part, and have fewer spinules, but are otherwise similar. On the old parts the four outer rows of paxillæ are distinctly larger than the others, but not equal among themselves. Those of the outer row are roundish with a convex rosette of about ten to twelve rather stout, clavate spinules, one to three being central, besides a large number of marginal slender, fasciolated spinules. Those of the second row are transversely a little oblong, with sixteen to twenty similar spinules on top, in two series, in rosette form. Those of the third row are more nearly square with about twelve to sixteen spinules in the rosette. Those of the fourth row are somewhat smaller and have about twelve to fourteen spinules in the rosette. Those of the fifth row are decidedly smaller, nearly round, and more like those of the median area. They mostly have a regular, round, terminal rosette of seven to nine spinules, of which one or two are central. On the median area they become still smaller, with fewer spinules, and are crowded irregularly, with papulæ between them. On the repaired parts the outer row of paxillæ usually has the largest rosettes. 
On the old parts the marginal plates have six or seven slender, acute spines in a transverse row. The upper one is small and sharp; the second and third are long and subequal; below these, on the inferior side, are three or four much smaller ones, in a row. Between and around the spines are numerous slender, sharp spinules.

The inner spine of the adambulacral plate is small and strongly curved; the second, on the margin, is nearly straight, about twice as large; both are compressed. The next two are smaller, acute; they stand nearly side by side, divergent. Outside of these is a rather large, conical, erect pedicellaria on many of the plates. Most of them have three valves; some only two.

Similar three-valved pedicellariæ of larger size occur on the interradial areas; four or five on each.

Station 2403, off West Florida, in 88 fathoms (No. 10449).

\section{Luidil convexiuscula Perrier.}

Luiclia convexiuscula Perrier, op. cit., 1881, p. 30; Etoiles de Mer, p. 268, pl. $x$, fig. 6,27 1884 .

A very slender six-rayed species. The type has the radii $5^{\mathrm{mm}}$ and $28^{\mathrm{mm}}$; ratio, $1: 5.6$.

Perrier gives the following characters:

Dorsal surface slightly convex, with the paxillæ almost equal, but a little smaller upon the median part of the rays and on the disk. They bear small, nearly equal, divergent spinules; the central ones are a little larger than the rest, but are not prolonged into a spine. There are about fifteen rows of paxillæ.

The inferomarginal plates are short, covered with small spines, and bear a single long marginal spine.

The adambulacral plates have one long, compressed, recurved furrow-spine, and outside of it a cluster of smaller spines.

Perrier recorded this species from six Blake stations, in 56 to 208 fathoms, among the Lesser Antilles, and in one station, in the Gulf of Mexico, in 101 fathoms.

Some of these specimens were examined by me in 1896 .

27 The references to the figures of this and the preceding species were incorrectly given by Perrier (1884) in his text. 


\section{Lumia MarcgraviI Lütken.}

Luidia marcgravii (Steenstrup MSS.) Lütken, op. cit., 1859, p. 43. Verrill, op. eit., 1867, p. 343.

Stella marina, Marcgrave, Hist. Rerum nat. Brazil, viii, p. 189, 1648.

Asterias 4. "The large starfish with eight or more slender arms" Browne, Civil and Nat. Hist. Jamaica, 393, 1756.

Luidia senegalensis (pars) Müll. and 'Trosch., Syst. Aster., p. 78, 1842 (non

Lam.). Perrier, Revision, p. 262, 1876. R. Rathbun, op. eit., p. 149, 1879.

A large species, up to $360^{\mathrm{mm}}$ in diameter, with a disk of $51^{\mathrm{mm}}$, almost always with nine slender, flattened, narrow rays; rarely eight. It is very fragile like most other species of the genus.

The larger lateral paxillæ are triseriate, rectangular, covered with about fifteen obtuse, central granules, surrounded by numerous setiform marginal spinules. The paxillæ in the median radial area are much smaller and minute.

A triangular area, bearing paxillæ, is intercalated in the interradial area, between the second and first rows of lateral paxillæ.

The inferomarginal plates are densely covered with short flat spines, larger centrally, and bear two larger, short, biserial, marginal spines. Adambulacral plates bear three or four compressed spines, the two inner ones curved.

The color, in life, according to Clark, is greenish or grayish above, yellow below, much as in $L$. clathrata, from the same places.

Our dried specimens are light gray with a darker bluish gray medial stripe, on each ray. Both have nine rays.

Perrier (1876) states that he has compared specimens from w Africa with others from Brazil and Guadeloupe and found no difter ances.

Lütken, however, made a very careful study of the American species and found it distinct, though nearly allied. He was certainly a very expert authority on starfishes.

Personally I have not been able to study a sufficient number of specimens from both regions to warrant any decided opinion. It is generally admitted that some other species of Echinoderms are common to the W. African and American seas.

Originally this species was recorded from Brazil by Marc- 
grave (1648), and a century later, by Browne (1756) from Port Royal and Kingston, Jamaica, where it has recently been found by Clark, in very shallow water, at Port Royal. Cotinguiba, Brazil, and San Domingo (Luitken). Pernambuco, Brazil, abundant (Rathbun), and Yale Mus., coll. C. F. Hartt, No. 5,201.

I do not know that it has been taken on the Florida coasts, or at the Bahamas. It seems to abound most on the tropical coast of Brazil. The Yale Museum has a cotype from Brazil, No. 1,343, sent by Lütken. 


\section{BIBLIOGRAPHY}

In the following list, most of the works relating particularly to West Indian starfishes have been included. Many of the early ante-Linnean works and later general works and text books have been omitted, though some that have been quoted above are included. Others, not here included, are quoted in full in the synonymy of particular species.

Although this list does not profess to be emplete, it is believed that it will prove useful, for no such bibliography of this subject has hitherto been published for the West Indian fauna.

Agassiz, Alexander. Preliminary Report on the Echini and Starfishes dredged in deep water between Florida and Cuba reefs, by L. H. de Pourtalès, Bull. Mus. Comp. Zoology, vol. i no. 9, pp. 253-308, 1869. (List of starfishes, eight species, on p. 308.)

- North American Starfishes. Memoirs Museum Comparative Zoölogy Harvard College, vol. v, no. 1, 4, 136 pp., 20 pls., Cambridge, Mass., 1877.

The first part relates to the embryology of Asterias. The second part includes descriptions and excellent figures, partly structural, of various species, including several from Florida and the West Indies, viz. Oreaster reticulatus, Echinaster sentus, Astropecten articulatus, Luidia clathrata, Linckia guildingii, Asterina folium.

- Three Cruises of the Blake. 2 volumes. In Bulletin Mus. Comp. Zoöl., vol. xv. Starfishes are in vol. ii, pp. 102-109, with figures 377387, 1888.

Agassiz, L. Prodrome d'une Monographie des Radiares ou Echinodermes. Mém. Soc. Sci. Nat. Neuchâtel, vol. i, pp. 168-199, 1835.

Blainville. See De Blainville, 1835.

Browne, Patrick. The Civil and Natural History of Jamaica, iii, 1756. Includes Oreaster reticulatus, etc. Not binomial.

Bruguieries, Histoire Natur. des Vers., Encyclopédie Méthodique. Paris, 1791.

Clark, Hubert Lyman. Notes on the Echinoderms of Bermuda. Annals New York Acad. Science, no. 19, vol. xi, pp. 407-413, Sept., 1898.

- The Echinoids and Asteroids of Jamaica, Johns Hopkins Univ. Circulars, no. 137, pp. 1-6, Nov., 1898.

Includes 14 species of Asteroids, with brief descriptions. 
- Some Japanese and East Indian Echinoderms. Bulletin Museum of Compar. Zoölogy, vol. li, p. 236, 1908.

Includes an analytical table of all described species of Pteraster.

De Blaniville. Dictionaire des Sciences Naturelles, vol. iii, Article "Asterie." 1804.

-. Manuel d'Actinologie. Paris, 1834.

Duchassaing, P. Anim. Rad. des Antilles. Paris, 1850.

DUJARDIN ET HUPÉ. Echinodermes, in Suites a Buffon. 1862. (Largely a translation of Müll. and Trosch., Syst. Asteriden.)

Various errors of translation have been noticed by Perrier, op. cit., 1875, 1876. Some relate to W. Indian species.

Field, G. W. Echinoderms of Kingston Harbor (Jamaica). Johns Hopkins University Circular for April, 1892.

Fisher, WALTER KeNDRICK. Necessary Changes in the Nomenelature of Starfishes. Smithsonian Miscell. Collections, vol. lii, pp. 87.93, 1908a.

- Some Necessary Changes in the Generic Names of Starfishes. Zoölogischer Anzeiger, vol. xxxiii, no. 11, August 18, pp. 356-359, 1908 .

- The Genus Blakiaster. Bull. Mus. Comp. Zoöl., vol. liv, no. 4, pp. 161-165, pls. i, ii, $1911 a$.

Diseusses also Leptychaster and Bunodaster.

- Asteroidea of the North Pacific and adjacent Waters. Part I. Phanerozonia and Spinulosa. Bulletin 76, Smithsonian Institution. 419 pp., 4to, 122 plates, $1911 b$.

Forbes, Edward. A History of British Starfishes and other Animals of the Class Echinodermata, $8^{\circ}, 269 \mathrm{pp}$., London, 1841. Published in six monthly numbers, the first of each month, from October, 1840, to March, 1841 (teste Bell, op. cit., 1890, p. 493). 1840-41.

GMELin. Linné, Systema naturæ, ed. xiii, p. 3161. 1789.

Gray, Jorrn Edward. A Synopsis of the Genera and Species of the Class Hypostoma (Asterias Linnæus). Ann. Mag. Nat. Hist., vol. vi, London, 1840 (pp. 175-184, November, 1840a; pp. 275-290, December, $1840 b)$.

- - Ann. Mag. Nat. Hist., vol. xx, $1847 a$.

- Descriptions of Some New Genera and Species of Asteriadæ, Proc. Zoöl. Soc. London for 1847 , pp. 72-83, $1847 b$.

- Synopsis of the Species of Starfish in the British Museum, pp. i-iv, 1-17; pl. i-xvi. London, 1866.

Griffiths, in Cuvier, Animal Kingdom, vol. xii, Sanborn, 1834.

GrubE, Edw. Archiv fur Naturgesch, vol. xxiii, p. 340.

Includes Astropecten ciliatus from Puerto Cabello.

HaManN, Oтto. Echinodermen. Bronn's Klassen und Ordnungen des Thier-reichs, Heft 2, Abth. 3, pp. 657-719, 1899.

Hartog, Marcus M. True Nature of the Madreporic System of Echinodermata, with Remarks on Nepliridia. Ann. and Mag. Nat. Hist., pp. 321326, November, 1887. 
Herapath, W. B. On the Pedicellariæ of the Echinodermata. Quarterly Journ. Micros. Sci., vol. v, p. 175, 1886.

Ives, Charles. The Isles of Summer, Nassau and the Bahamas. Pp. 356, 16mo, 14 text cuts, 12 plates. New Haven, Conn., 1880. Published by the author.

Contains a good figure of Oreaster gigas, pl. 19, fig. 2, and figures of other echinoderms, corals, fishes, shells, etc., by J. H. Emerton.

Ives, J. E. Catalogue of the Asteroidea and Ophiuroidea in the Collection of the Academy of Natural Sciences of Philadelphia; Proc. Acad. Nat. Sci. Philadelphia, for 1889, p. 160 (distribution), 1889.

- Echinoderms from the Northern Coast of Yucatan and the Harbor of Vera Cruz. Proc. Acad. Nat. Sci. Pliladelphia, pp. 317-340, pl. viii, 1890.

- Echinoderms from the Bahama Islands. Proc. Acad. Nat. Sciences, Philad., for 1891, pp. 337-341, pl. xvi, 1891a.

-. List of the Echinoderms and Crustacea in the Cabinet of Frederick Stearns, Detroit, Mich. Private publication, not dated; $1891 b$.

LAMarCK, J. B. P. A. DE. Histoire Naturelle des Animaux sans Vertèbres. First ed., vol. ii, Paris, 1816.

- - Second ed., vol. iii, 1840.

Linck, Joh. Henr. De Stellis marinis, folio, 107 pp., 42 pls., Lipsiæ, 1733.

Linne, Card. Museum Tessinianum, 1753.

Includes Asterias gigas (Oreaster).

- Systema Nature, ed. x, 1758.

- Ditto, ed. xii, 1766.

. Ditto, ed. xiii. See Gmelin.

Ludwig, Hubert. Verzeichniss der von Prof. Dr. Ed. Van Beneden an der Küste von Brazil, gessamelten Echinodermen. Mem. Cour. Acad. Roy. Belgique, vol. xliv, no. 5, 1882.

—. Die Seesterne des Mittelmeeres, $4^{\circ}, 191$ pp., 12 pls., Berlin, 1897.

- Arktische Seesterne. In Fauna Arctica (Röner and Schaudin), vol. i, article xiv, pp. 447-502, Jena, 1900.

- Notomyota, eine neue Ordung der Seesterne. Sitzungsber. k. preuss. Akad. Wiss., vol. xxiii, April, pp. 435-466, 1910.

Lü.tKen, Christian Frederick. Bidrag til Kundskab. om de ved Kysterne af Mellen-og Syd-Amerika levende Arter af Söstjerner. I, Naturhist. Foren., Vidensk. Meddel. Kjobenhavn, 1859.

- Kritiske Bemaerkninger on forskjellige Söstjerner (Asterider), med Beskrivelse af nogle nye Arter, ii, Naturhist. Foren., Vidensk. Meddel. Kjobenhavn, for 1864, pp. 123-169, 1865.

- Fortsatte kritiske og beskrivende Bidrag til Kundskab om Söstjernerne (Asteriderne), iii, Naturhist. Foren., Vidensk. Meddel. Kjobenhavn, for 1871, pp. 227-304, pls. iv, v, 1871.

Marcgraf, George. Historia naturalis Brasilix, vol. viii, 1648.

Includes Luidia marcgravii and Oreaster reticulatus. 
Mobius, Neue Seesterne des Hamburger und Kieler Museums. Hamb.

Abhand. Geb. Naturw., iv, 1859.

Includes Asteriscus stellifer, Brazil.

Müller, Johan, and Troschel, Franz Hermann. In Wiegmann's Arehiv, vi, Bd. i, pp. 318-326, Sept., 1840.

- Monatsb. Preuss. Akad. Wiss., p. 102, April. Berlin, 1841.

System der Asteriden, 3, Braunschweig, 4 134 pp., 12 pls., 1842.

Beschreibung neuer Asteriden. Arehiv fur Naturgeschichte, 10.

Jahrg., Bd. i, pp. 178-185, 1841.

MüLler, P. L. S. Carl v. Linné's vollstan. Natursystem, vol. vi, 1775.

Nachtrieb, H. F. Notes on Echinoderms obtained at Beaufort, N. C.

Johns Hopkins Univ. Studies from the Biolog. Laboratory, vol. iv, p. $81,1887$.

The author seems unaware of the earlier list by the writer. (See Verrill, A. E., op. cit., 1872.)

NARDO, J. D. De Asteriis, Oken's Isis, heft iii, pp. $716-717,1834$.

Nutring, C. C. Narrative and Preliminary Report of Bahama Expedition.

In Bull. Labor. Nat. Hist. State Univ. Iowa, vol. iii, nos. 1, 2, pp. 1-251, 1895. Starfishes are treated on pp. 78, 130, 135, 165-169, 212, and plate.

Contains notes on habits and colors in life.

Perrier, Jean Octave Edmond. Recherches sur les Pedicellaires et les Ambulacres des Astéries et des Oursins, $4^{\circ}, 188$ pp., 2 pls., Paris, 1869. In Ann. Sci. Nat. Zoöl. (5), vol. xii, pp. 197-304, pls. xvii-xviii, Paris, 1869 ; vol. xiii, article i, pls. ii-vi, 1870.

- Sur les Pedicellaires des Astéries et des Oursins. Arch. Zoöl. Exper. et Génér., iii, pp. vii-xv, 1874.

- Classif. et la Synonym. des Stellerides. Comptes rendus, No. 81, 1875, p. 1271, $1875 a$.

Contains observations on Goniaster americanus.

- Revision de la Collection de Stellerides du Muséum d'Histoire Naturelle de Paris, $8^{\circ}, 384$ pp., Paris, $1875 b$ (Asteriidæ, Echinasteridæ, Ophidiasteridæ). Arch. Zoöl. Exper. et Génér., vol. iv, pp. 265-450. 1875c. Vol. v, pp. 1-104 (Goniasteridæ); 209-304 (Asterinidæ, Astropectinidæ, Pterasteridæ). $1876 a$.

- Diagnoses of new species of Asteriidæ and Linckiidæ in the British Museum. Ann. and Mag. Nat. History, ser. 4, vol. xvii, pp. 34-36, 1876b. Translation by E. A. Snitli.

- On the Classification and Synonymy of the Stellerida. Ann. and Mag. Nat. History, ser. 4, vol. xvii, pp. 259-261, $1876 c$.

A translation of No. $1875 a$. It contains many statements in regard to the synonymy of the species of Lamarck, Gray, Müller and Troschel, and others, based on examinations of the original types, but without descriptions.

_. Les Stellerides des Illes du Cap Vert, Voy. Expl. A. Bouvier, Zoöl. Soc. France, Bull., ii, pp. 241-246, 187 i. 
Etudes sur la Répartition Géographique des Asterides. In Nouv. Arch. Mus. Hist. Nat., ser. 2, vol. i, pp. 1-108, 1878.

- Les Stellerides de l'Isle Saint Paul. Arch. Zoöl. Exper. et Gen., vol. viii, pp. 47-49, 1879-80, 1879.

- Les Etoiles de Mer des regions profondes du Golfe du Mexique. Paris Acad. Sci., Comptes Rendus, No. 91, pp. 436-439, 1880.

Contains Zoroaster ackleyi, Z. sigsbei, Hymenodiscus, gen. nov.

—. Sur les Etoiles de Mer, draguées dans les region. prof. du Golfe du Mexique, et de la Mer des Antilles par le navaire "The Blake," Paris Acad., Comptes Rendus, No. 92, pp. 59-61, 1881a.

Contains Anthenoides peircei nov.

- Description Summaire des Espèces nouvelles d'Astéries, Bulletin Mus. Comp. Zoölogy, vol. ix, no. i, pp. 1-31, June, $1881 b$.

These descriptions are reproduced, with few changes, in the final report, 1884.

- Les Campagnes du Travailleur, Assoc. France, Comptes Rendus, pp. $577-583,1883 a$.

- Expedet. de Talisman. Revue Sci., vi, pp. 737-741, $1883 b$.

- Mémoire sur les Etoiles de Mer, rec. dans la Mer des Antilles et la Golfe du Mexique (Blake Expedition). Nouv. Arch. du Mus. d'Hist. Nat., ser. 2, vol. vi, pp. 127-276, pls. i-ix, 1884.

- Note Preliminaire sur les Echinodermes, rec. par le Travailleur et la Talisman. In Nouv. Arch. Mus. Hist. Nat., ser. 2, vol. vi, p. 154, 1885.

- Echinodermes de la Mission Scientifique du Cape Horn; I, Stellerides. Mission Scientifique du Cape Horn, Zoölogie, vol. vi, 198 pp., 13 pls., Paris, 1891a.

- Stellerides Nouveaux provenant des Campagnes du Yacht L'Hirondelle. In Mém. Soc. Zoöl. de France, vol. iv, pp. 258-271, Paris, $1891 b$.

-. Echinodermes; I, Stellerides. Expéditions Scientifiques du Travailleur et du Talisman pendant les Annees 1880-83, 4², 432 pp., 36 pls. In Archives des Missions scientifique et littéraires. Raport sur les Travaux de la Comm. chargée par M. le Ministere de l'Instruction publique d'etudier la Faune sous-marine dans les grandes profoudeurs de la Méditerranée et de l'Ocean Atlantique, par M. Alphonse Milne-Edwards. Ser. 3, vol. ix. Paris, 1894.

In this important work many of the West Indian species, from the Blake Expeditions, are redeseribed more fully and often under revised generic names. On pages 36 to 40 there is a list of all the species obtained by the Blake in the West Indies and Gulf of Mexico.

—. Contribution a l'Étude des Stellerides de l'Atlantique Nord (Golfe de Gascogne, Acores, Terre-Neuve). Résultas des Campagnes Scientifiques accomplies sur son Yacht par Albert I., Prince Souverain de Monaco, fase. xi, 4to, 59 pp., 4 pls., Monaco, 1896. 
Rathbun, Richard. A List of the Brazilian Eehinoderms, with Notes on their Distribution, etc. Trans. Conn. Acad. Science, vol. v, pp. 139-158, June, 1879.

ROCHEFORT. Historische Beschreibung der Antillen-Inseln in Amerika gelegen, Frankfurt, 1668.

Includes Oreaster reticulatus.

Rondelet. Libri de Piscibus Marinis, 1554.

Includes Oreaster reticulatus.

SARS, MichaEl. Bidrag til Kundskaben om Middelhavets Littoral-Fauna, 1857.

Say, Thomas. On the Species of the Linnæan Genus Asterias inhabiting the Coast of the United States. Journal Acad. Nat. Sciences Philadelphia, Ser. i, vol. v, pp. 141-154, 1825.

Contains descriptions of 6 Asterioidea; 12 Ophiuroidea; 1 Crinoidea Extract in Ferrusac. Bull. des Seiences Naturelles, vol. xii, pp. 401403.

Seba, Albertus. Locupletissimi rerum naturalium Thesauri, vol. iii, 1761. Contains recognizable figures of some West Indian species.

Sladen, WM. Percy. Traces of Ancestral Relations in the Structure of the Asteroidea. Proe. York Geolog. and Polytech. Soc., N. S., vol. vii, 10 pp., pl. iv, 1880 .

- Asteroidea dredged during the Cruise of the Knight Errant in July and August, 1880. Proc. Roy. Soe. Edinburgh, 1881-1882, pp. 698$707,1882$.

Asteroidea dredged in the Faeröe Channel during the Cruise of $\mathrm{H}$. M. S. Triton, in August, 1882. Trans. Royal Soc. Edinburgh, vol. xxxii, part i, pp. 153-164, pl. xxvi, $1883 a$.

- The Asteroidea of H. M. S. Challenger (Preliminary Notices). Part ii, Astropectinidæ. Journal Linn. Soc. London, vol. xvii, pp. 214$269,1883 b$.

- On the Homologies of the Primary Larval Plates in the Test of Brachiate Echinoderms. Quarterly Journ. Microscopic Soc., pl. i, London, 1884.

- Report on the Scientific Results of the Voyage of H. M. S. Challenger. Narrative of the Cruise, $i$, part 2, 1885a.

- Report on the Asteroidea. Report on the Scientific Results of the Voyage of H. M. S. Challenger during the years 1873-76, Zoölogy, vol. xxx and a volume of 117 plates, London, 1889.

Sloane, Hans. A Voyage to the Islands Madera, Barbadoes, Nieves, St. Christophers, and Jamaica, with the Natural History, ete. Vol. ii, 1725.

Thompson, Wrville. The Depths of the Sea. London, 1873.

Troschex, Franz Hermann. See Müller, Johan, and Troschel, Franz Hermann.

VerRILl, AdDison Emery. On New and Imperfectly Known Echinoderms and Corals. Proc. Boston Soc. Nat. Hist., vol. xii, pp. 381-396, 1869. 
Notes on Radiata. Trans. Conn. Acad. Arts and Sciences, vol. i, number 2, pp. 247-613, pls. iv-x, New Haven, 1867-1871.

No. 3. On the Geographical Distribution of the Echinoderms of the West Coast of America (and Comparison of the Tropical Echinoderm Faunæ of the East and West Coasts of America). Trans. Conn. Acad. Sciences, i, pp. 323-351, 1867c. Reprint, 1870, with additions in footnotes.

- No. 4. Notice of the Corals and Echinoderms collected by Prof. C. F. Hartt, at the Abrolhos Reefs, Province of Bahia, Brazil, in 1867. Trans. Conn. Acad. Science, vol. i, pp. 351-371, pl. iv, Feb., 1868.

Includes four starfishes. Two are deseribed as new species, viz., Echinaster crassispina and Asterias atlantica.

- Descriptions of Starfishes and Ophiurans from the Atlantic coasts of America and Africa. Amer. Jour. Science, rol. ii, pp. 130-133. 1871a.

—. On Radiata from the Coast of North Carolina. Brief Cont. to Zoöl. No. xxii, Amer. Journ. Sei., vol. iii, pp. 432-438, June, 1872.

- Results of Recent Dredging Operations on the Coast of New England. In Amer. Journ. Science and Arts (3), vol. v, pp. 1-16, 1873a; $98-106,1873 b$; vol. vi, pp. $435-441,1873 c$.

. Report upon the Invertebrate Animals of Vineyard Sound, etc., Washington, 1873d. In Report of the Commissioner of Fish and Fisheries for 1871, pp. 295-778, pls. i-xxxviii, 1873-74. Also author's edi. tion, repaged, 1874 .

- Note on some of the Starfishes of the New England Coast. In Amer. Journ. Science and Arts (3) vol. xi, pp. 416-420, New Haven, 1876.

Corrections of Errors made by M. E. Perrier, in respect to New England species of Asterias.

- Notice of Recent Additions to the Marine Fauna of the Eastern Coast of North America, nos. 1 and 2. In Amer. Journ. Science and Arts (3), vol. xvi, pp. 207-215, 371-378, New Haven, 1878a, and $1878 b$.

- Notice of Recent Additions to the Marine Invertebrata of the Northeastern Coast of America, with Descriptions of New Genera and Species and Critical Remarks on Others. Proc. U. S. Nat. Mus., vol. ii (1879), pp. 165-205, Washington, 1880a.

- List of Marine Invertebrata from the New England Coast. Proc. U. S. Nat. Mus., vol. ii (1879), pp. 227-232, Washington, $1880 b$.

- Notice of the Remarkable Marine Fauna Occupying the Outer Banks off the Southern Coast of New England, No. 1, no. 3 and no. 4, Amer. Journ. Seience, no. 1, vol. xx, pp. 390-403, 1880c; no. 3, vol. xxxiii, pp. 135-142, 1882a; no 4, 216-225, New Haven, $1882 b$.

—. The same, no. 9, vol. xxviii, pp. 213-220, 1884a.

—. The same, no. 10, vol. xxviii, pp. 378-384, $1884 b$.

—. Tlie same, no. 11, vol. xxix, pp. 149-157, $1885 a$. 
Notice of the Remarkable Marine Fauna Occupying the Outer Banks off the Southern Coast of New England, and of Some Additions to the Fauna of Vineyard Sound. In the Annual Report of the U. S. Commissioner of Fish and Fisheries for 1882, 26 pp., $1884 c$.

- Results of the Explorations made by the steamer Albatross off the Northern Coast of the United States in 1883. In the Annual Report of the Commissioner of Fish and Fisheries for 1883, pp. 1-107 (503-699), 44 pls., Washington, 18856 .

Geographical and bathymetrical distribution.

- Descriptions of new Species of Starfishes and Ophiurans, with a Revision of Certain Species formerly Described. Proc. U. S. Nat. Mus., vol. xvii, pp. 245-297, Washington, 1894.

- Distribution of the Echinoderms of Northeastern America. Amer. Journ. Science, vol. xlix, pp. 127-141, 199-212, New Haven, 1895a. Abstract by H. Ludwig in Zoöl. Centralblatt, p. 40, February 2, $1895 b$.

- Revision of Certain Genera and Species of Starfishes, with Descriptions of New Forms. Trans. Conn. Acad. of Arts and Sciences, vol. x, part i, pp. 145-234, pls. xxiva-xxx, New Haven, 1899.

- Additions to the Echinoderms of the Bermudas, op. cit., vol. $x$ (part 2, Sept., 1900), pp. 583-587. 1900.

- Additions to the Fauna of the Bermudas from the Yale Expedition of 1901 (47 pp., pls. i-ix; 6 cuts in text), 1901. Trans. Conn. Acad. Sci., vol. xi, pp. 15-62, 1901.

Habits of Luidia clathrata on p. 36 ; rapid progression, ete.

Zoölogy of the Bermudas, vol. i, 427 pp., 45 pls., 1903.

Starfishes are discussed in article 10, p. 36.

- The Bermuda Islands, part 5, section i, Characteristic Life of the Bermuda Coral Reefs. Trans. Conn. Acad. Sci., vol. xii, pp. 160-316, 28 pls., 1 map, 120 text cuts, 1906.

Starfishes are discussed on pp. 280-281, pls. xxiv, xxxivc, xxxvic.

- Revision of the Genera of Starfishes of the Subfamily Asterininæ. Amer. Journ. Science, ser. 4, vol. xxxv, pp. 477-485, 2 text cuts, May, 1913.

Eight new genera established.

- Monograph of the Shallow-water Starfishes of the North Pacific Coast, from the Arctic Ocean to California, with Rerisions of various Extralimital Genera and Species. Harriman Alaska Series, vol. xiv, pp. 420, and a volume of 110 plates. Published by the Smithsonian Institution, $1914 a$.

- Review in Science, vol. xl, no. 1032, pp. 523-525, Oct. 9, 1914; and in Amer. Journ. Science, vol. xxxviii, p. 107, 1914, with errata.

- Nomenclature of Certain Starfishes. Amer. Journal Science, vol. xxxvii, p. 483, May, 1914b. Treats of Anseropoda luna (L.); Acanthas. ter planci (L.). 
Revision of some New Genera and Species of Starfishes, with Descriptions of a few New Genera. Annals and Magazine of Natural History, vol. xiv, No. 79, pages 13-22, plate I, July, $1914 c$.

Treats mostly of the family Poraniidæ.

- Report on the Starfishes of the West Indies, Florida, and Brazil, including those obtained by the Bahama Expedition from the University of Iowa, in 1893, 230 pp., 29 plates. 1915.

Viguier, C. Anatomie comparée du Squelette des Stellerides. Arch. Zoöl. Expér. et Génér., vol. vii, pp. 33-250, pls. v-xvi, 1879. 


\section{LIST OF SPECIES HEREIN DESCRIBED OR FIGURED}

Those prefixed by an asterisk $\left(^{*}\right)$ were taken by the Bahama Expedition. Those with a dagger $(\dagger)$ are extralimital, or from deep water.

Family AsTerid $\approx$

* Orthasterias subangulosa Verrill, nom. nov. Pl. ii, figs. 1, 2; pl. ix, figs. $1,1 a$

O. contorta (Per.)

Leptasterias fascicularis (Per.)

L. hartii Rathbun

L. mexicana (Lütken)

Coscinasterias linearis (Per.)

C. tenuispina (Lam.). Pl. xxvi, fig. 2 ; pl. xxvii, fig. 4 .

* Stephanasterias gracilis (Per.). Pl. ix, fig. 2-2c

S. hebes Ver. nov. Pl. ix, fig. 3. Type

Family ZOROASTERID

Zoroaster ackleyi Per.

Family Pedicellasterid 皮

* Coronaster briareus Ver. Pl. i, figs. 1, 2 ; pl. ix, figs. 4-4c

* Pedicellaster pourtalesii Per.

Family ECHINASTERID巫

* Echinaster sentus (Say). Pl. xxix, fig. 2

E. spinulosus Ver. Plate iv, figs. 1, 2. Types

E. braziliensis M. and Tr. Pl. xxvi, fig. 1

E. echinophorus (Lam.)

E. modestus Per.

Thyraster serpentarius (M. and Tr.)

Henricia antillarum (Per.)

* H. sexradiata (Per.). Pl. xi, fig. 7

H. microspina Ver. nov.

Family SolasterIde

* Lophaster radians Per. Pl. v, fig. 2 ; pl. vii, fig. 3 ; pl. xi, figs. 1-1c

Solaster caribæus Ver, nov. Pl. xxviii, figs. 1-1a. Type

Family KORETHRASTERID E

* Remaster palmatus Per. Pl. xi, fig. 2

Family AsterinIID $\mathbb{E}$

+ Asterina gibbosa (Penn.)

* Asterinides folium (Lütken). Pl. iii, fig. 5 ; pl. xi, fig. 4; pl. xxviii, fig. 2

† Asterinides modesta Ver. Pl. xxvii, figs. 1, 2. Types

Enoplopatiria marginata. Pl. vii, fig. 2. Brazil 
† E. siderea Ver. Pl. xxvii, figs. 3-3a

Asterinopsis pilosa (Per.)

A. lymani (Per.)

* Stegnaster wesseli (Per.). Pl. iii, figs. 3-3a

Family Poranidde

† Rhegaster spinulosus Verrill

$\nmid \mathrm{R}$. borealis Verrill. Pl. x, figs. 3, 3a. Type.

Poraniella regularis Verrill. Pl. vii, figs. $1-1 a$; pl. $\mathrm{xv}$, figs. $5-5 b$. Types

P. echinulata (Per.)

Marginaster pectinatus Perrier

Porania (?) austera Verrill. Pl. iii, figs. 1-1a; pl. xi, figs. 6, $6 a$. Types

† Poranisca lepidus Ver. Types. Pl. iv, figs. 3-7; pl. x, figs. 4-4a; pl. $\mathrm{xv}$, fig. 6. See op. cit., $1914 c$

$\dagger$ Culcitopsis borealis (Suss. \& Breckner) Ver.

Family PTERASTERId \&

Pteraster caribbæus Perrier. Pl. vii, fig. 4

Family OPHIDIASTERIDA

Ophidiaster guildingii Gray

O. floridæ Perrier

O. alexandri Ver., nov. Pl. xiii, figs. $3-3 b$; pl. xxv, fig. 2. Type

* Linckia nodosa Per. Pl. xiii, figs. $2,2 a$; pl. xxix, figs. $1 a, 1 b$

L. guildingii Gray. Pl. xxviii, fig. 3

Narcissia trigonaria Sladen

Family OrEASTERIDE

* Oreaster reticulatus (Linn.)

Family Goniasteride

* Goniaster americanus Ver. Pl. xiii, figs. 5-5a. Type

Mediaster pedicellaris (Per.)

* Rosaster alexandri Perrier. Pl. xvii, fig. 2; pl. xi, figs. 3-3b

* Anthenoides peircei Perrier. Pl. iii, fig. 2 ; pl. x, figs. $1-1 b ; 2-2 f$

Family ChaTASTERID

* Chætaster nodosus Perrier. Pl. viii, figs. 1, 2; pl. xiii, figs. 4-4c

C. longipes (?) Sladen

Family Odontasteride

Odontaster hispidus Ver. Pl. xiii, fig. 6 .

Family Benthopectinide

* Cheiraster mirabilis Perrier. Pl. xiv, figs. 5, $5 a$

C. mirabilis coronatus (Per.)

* C. echinulatus Per. Pl. xiv, fig. 3 ; pl. xix, fig. 2 ; pl. xxv, fig. 1

† C. planus Ver. nov. Pl. xviii, fig. 2. Type

†C. enoplus Ver. nov. Pl. xviii, fig. 1. Type

Pectinaster vincenti Per. 
* P. mixtus Ver. nov. Pl. xv, fig. 2 ; pl. xvii, fig. 1; pl. vi, fig. 2. Type

* P. gracilis Ver. nov. Pl. vi, fig. 1 ; pl. xv, figs. $1-1 b$; pl. xiv, fig. 4. Type

P. oligoporus Per.

P. dispar Ver. nov. Pl. xiv, figs. 1-1b. Type

† Pectinaster (Pontaster) forcipatus (Sladen). Pl. xv, figs. 3, 4. Young

† Pontaster sepitus Ver. See foot-note, p. 130.

Family Astropectinide

* Astropecten articulatus (Say)

A. articulatus dubius (Gray)

A. duplicatus Gray. Pl. xxii, fig. 2 ; pl. xxiii, fig. 1.

A. duplicatus variabilis (Lütken). Pl. xvi, figs. $2,2 a$; pl. xxiii, fig. 2

A. antillensis Lütken

A. braziliensis M. and $\mathrm{Tr}$.

A. comptus Ver. nov. Pl. xii, figs. $3-3 c$; pl. xxii, fig. 1

A. richardi Per.

A. cingulatus Sladen

A. nitidus Ver. nov. Pl. $x x$, fig. 2

A. nitidus forcipatus Ver. nov. Pl. xvi, fig. 3 ; pl. $x x$, fig 1

A. alligator Per.

* A. nuttingii Ver. nov. Pl. xii, figs. 2-2e; pl. xxi, figs. 1, 2

A. americanus Ver. Pl. xvi, figs. 1, 1a

A. americanus subgracilis Ver. nov.

A. ciliatus Grubé

* Blakiaster conicus Per. Pl. iii, fig. 4 ; pl. xi, fig. 5; pl. xiii, figs. 1-1c

Sideriaster grandis Ver. Pl. xii, figs. 5-5b. Type

$+\mathrm{S}$. ( ) vestitus (Say)

† Plutonaster intermedius Per.

Family Goniopectinides

Prionaster elegans Ver. Pl. xii, figs. 4-4c. Type

Family Luididis

* Luidia elathrata (Say). Pl. xxiv, fig. 2

* Luidia alternata (Say)

* Luidia alternata bicolor Ver. nov. Pl. xii, figs. 1-1c

Luidia elegans Per. Pl. xvi, figs. 4, 4a; pl. xix, fig. 1

Luidia barbadensis Perrier. Pl. xxiv, fig. 1

Luidia convexiuscula Perrier

Luidia maregravii Lütken. Pl. v, fig. 1. Cotype 


\section{LIST OF DEEP SEA SPECIES NOT DESCRIBED IN THIS REPORT}

\section{Family BRISINGID æ}

Hymenodiscus agassizii Perrier, $1881 ; 1884 ; 1894$, pp. 45, 52; 391-450 fath.

Freyella, sp. near F. sexradiata

Brisinga cricophora Sladen, 1859. Off Bermuda; 390 fath.

Brisinga, near $B$. costata

Brisinga, near $B$. elegans

Family ZCROASTERID

Mammaster sigsbei Per., 1881; 1884; 1894, p. 125; 208-324 fath.

Zoroaster fulgens Sladen, off Brazil, 675 fath.; off E. N. Amer. coast, 1250-1350 fath.

Family SOLASTERID

Radiaster elegans Per. 1881; 1884; 1894, p. 174; 982 fath.

Ctenaster spectabilis Per. $1881 ; 1884 ; 1894$, p. $155 ; 1920$ fath. Probably the same as Pteraster spectabilis Perrier in lists (without description).

Family Pterasterid \&

Hymenaster, sp.

Hymenaster, sp.

Calyptraster coa Sladen, 1889, p. 489, pl. 78, 79. Off Brazil, 132-400 fath.

Family Ophidiasterid

Fromia, sp.

Family GONIASTERIDE

Ceramaster grenadensis (Per.) Verrill, 1899, p. 162; 176 fath.

Plinthaster comptus Ver., 1899, p. 163, pl. xxvii, fig. 2, 555-683 fath.

Plinthaster nitidus Ver., 1899, p. 165, pl. xxvii, fig. 1-1b; 335 fath.

Pyrenaster dentatus (Per.) Verrill, 1899, p. 167, pl. xxvii, fig. 3-3b; 250-1639 fath.

P. affinis? (Per.) Verrill, 1899, p. 168; 1131-1323 fath.

Peltaster nidarosiensis (Storm.) $=P$. hebes Ver., 1899, p. 169. See pl. xxviii, fig. $4,4 a ; 294$ fath.

Litonotaster intermedius (Per.) Verrill, 1899, p. 172, pl. xxviii, figs. $5-5 b, 1467-1930$ fath.

Hippasteria caribæa Ver., 1899, p. 174, pl. xxviii, fig. 1, 1a; 268 fath.

Cladaster rudis Ver., 1899, p. 176, pl. xxviii, figs. $2-2 c$; 440 fath.

Mediaster agassizii Ver., 1899, p. 181

Nymphaster ternalis (Per.) Verrill, 1899, p. 185, pl. xxvi, fig. 7; 1961181 fath. 
N. subspinosus (Per.), 1881, 1884 ; Verrill, 1879, p. 185; 163-388 fath.

N. arenatus (Per.), 1881, 1884; Verrill, 1899, p. 186; 164-874 fath.

N. basilicus Sladen, 1859, p. 308, pl. lvii, figs. 8, 9 ; Brazil, 1200 fath.

Pseudarchaster hispidus Ver., 1889, p. 191, pl. xxx, fig. 5; 600 fath.

P. ordinatus Ver., 1899, p. 194, pl. xxx, figs. $4-4 b ; 324-335$ fath.

P. granuliferus Ver., 1899, p. 192 ; pl. xxx, fig. 6, 6a. Sta. 2751.

Paragonaster subtilis (Per.), 1881; 1894, p. 358; Verrill, 1899, p. 196; 1930 fath.

Plutonaster intermedius (Per.), 1881; 1894, p. 316, des.; 833-955 fath.

P. efflorescens (Per.), 1884; 1894, p. 322 ; Verrill, 1899, p. 211 ; 955 fath.

P. pulcher (Per.), 1881; 1884; 1894, p. $332 ; 573$ fath.

Dytaster insignis Per., 1881; 1884; 1894, p. 299, des.; 1930 fath.

Dytaster sp., near D. robustus Ver.

Family Odontasteride

Odontaster sp., near O. setosus Ver.

Odontaster sp., compact species

Family BenthopeCtinider

Benthopecten simplex (Per.), 1881; 1894, p. 254, descr.; 1323 fath.

Family Goniopectinid 2

Goniopecten demonstrans Per., 1881; 1884; 1894, p. 295; Verrill, 1899, p. 213 , pl. xxvii, fig. 5 ; $335-358$ fath.

Family AstropeCtINID

Psilaster sp., near P. floræ Ver.

Leptychaster, sp.

Family Porcellanasterid $A$

Porcellanaster cœruleus Sladen

Ctenodiscus crispatus? (Retz.) 


\section{EXPLANATION OF PLATES}

\section{Plate I}

Figure 1. Coronaster brareus Verrill. Dorsal side, $\times 11 / 2$

Figure 2. The same specimen. Ventral side, $\times 1 \frac{1}{2}$

\section{Plate II}

Figure 1. Orthasterias subangulosa Ver. Ventral side, $\times 2$

Figure 2. The same specimen. Dorsal side, $\times 2$

\section{Plate III}

Figure 1. Porania (?) austera Ver. Type. Ventral side, $\times 13 \%$

Figure 1a. The same specimen. Dorsal side, $\times 1 \%$

Figure 2. Anthenoides peircei Per. Young. Ventral side. Much enlarged

Figure 3. Stegnaster wesseli (Per.). Ventral side, $\times 1 \%$

Figure $3 a$. The same. Dorsal side, $\times 1 \%$

Figure 4. Blakiaster conicus Per. Ventral side, $\times 1^{11 / 6}$

Figure 5. Asterinides folium (Lutk.). Ventral side, $\times 21 / 4$

\section{Plate IV}

Figure 1. Echinaster spinulosus Verrill. From West Florida. Under side, natural size. Type

Figure 2. The same, No. 7395, Yale Mus. Dorsal side, natural size

Figures 3-7. Poranisca lepidus Ver. Cotypes. Young of several sizes; dorsal and ventral sides; all from one locality. See Annals and Magazine Nat. Hist., vol. xix, page 19, pl. 1, fig. 3, Л., 1914c. See also pl. $\mathrm{x}$ and pl. $\mathrm{xv}$, below.

Plate V

Figure 1. Luidia marcgravii Lütken. No. 1343, Yale Mus. Cotype from Luitken. Dorsal side. About $1 / 2$ natural size.

Figure 2. Lophaster radians Per. Bahama Exped., station 64. Ventral side of an alcoholic specimen, $\times 21 / 4$. See also pl. vii, fig. 3 and pl. $x i$, figs. $1-1 c$.

\section{Plate VI}

Figure 1. Pectinaster gracilis Ver. Type. No. 10,564. Dorsal side, $\times 2$

Figure 2. Pectinaster mixtus Ver. Type. No. 10,226. Dorsal side, $\times 2$

\section{Plate VII}

Figures 1, 1a. Poraniella regularis Ver. Type. No. 10,190 N. M. Dorsal and ventral sides, $\times 11 \%$. See also pl. $x v$, figs. 5 , $5 a$, details

Figure 2. Enoplopatiria marginata Hupé, from Brazil. Dorsal side, $X$ 13/4. No. 1341, Yale, from Lütken.

Figure 3. Lophaster radians Per. Dorsal side, $1 / 2$ natural size.

Figure 4. Pteraster caribbaus Per. No. 18,415, N. Mus. Ventral view, $\times 2$ 


\section{EXPLANATION OF PLATES}

\section{Plate TTIT}

Figure 1. Chetaster nodosus Perrier. Ventral view. About 4/5 natural size.

Figne ״. The sime specimen. Dorsal riew, $4 / 5$ natural size.

\section{PlaAte IX}

Figure 1. Orthusterias subangulosu Verrill. Under side of mitdle of a raly, $\times 5$

Figmre 1a. The same specimen. Dorsal side, $X 5$

Figures 2, ¿a. Stephanastcrias gracilis (Perricr). ['nder side of portions of a ray, $\times 10$

Figure $2 b$. The same. Dorsil side, $\times 10$

Figure 2e. The same. Jat and under side of disk, $\times 10$

Nigure 3. S. hebes Verrill, nor. Type (No. 18,46). Under side of prortion of a ray, $\times 10$.

Figure 4. Coronaster briturens Terrill. Dorsal side of disk and bases of lays. of a specimen from station 61 , Bahana expedition; $\times 5$

Fignre $4 a$. The same specimen. Under side of bases of three rays and jaws of an alcoholic specimen; $\times 10$

Figure $4 b$. The same. Two of the dorsal spines witls groups of minor pediceliaria, $X$ about 30

Figure $4 c$. The same. One of the large felipedal pedicellaria. Much enlarged

\section{PLA'TE X}

Figne 1. Anthenoides peirec Perrier. Under side of a portion of a very young specimen, same as plate iii, figure $2 ; \times$ :

Figure la. The same sperincis. Dorsal side. $\times: ;$; nephridial or dorsal pore.

Figure 1b. The kame specinem. Alambulacal spines, $\times 7$.

Figures 2, 2a. The simme splecies. Under side of a riy of a young specimen, but considerably older than that of figure $1 ; \times 3$

Figures $2 b, 2 r$. The same. Dorsal side of a ray, $\times 3$

Figure 2 $d$. The same speeimen. Adambulacral spines, $\times 7$

Figure $2 c$. The same. Arlambulacral spines in profile; $f$, furrow-comb; $c$, row on antinal face; $\times 7$

rigure of The same sperimen. Tho bivalie pediechlaria, P.P', and atljacent interantinal plates; $\times 18$

Figure 3. Rhegaster horcalis Verrill. Type. No. 343. Yale. I'art of the ventral side of a ray, $X \bar{j}$

Figure 3a. The same specimen. (roup of dorsal papular pores, $\times \&$

Figures 4, 4a. Poranisea lepidus Verrill. Type. Station 2269. Ventral and dorsal sides, $\times 5$

Figure $4 b$. The same. One of the inferomarginal plates and group of spinules. See also pl. iv, figs. 3-7. 


\section{PuATE XI}

Figure 1. Lophaster rentians Perrier. Portion of dursal side of a ray $X: 2$. Figure 1a. The same specimen. Under side of portion of al lay of an al. cololie spevimen; po, podia; $a$, adambulacral spines; $i, i$ inferoma. ginals; $m$, supcron:arginials; $\times 5$

Fignre $1 b$. The same. One of the dorsal parapaxille; $\times 16$

Fignue $1 c$. The same. Artambulacial spines of one plate; $X 16$

Figure 2. licmaster palmatus Perrier. Dorsal view of a part of the lisk and two lilys, $X 6$. Many of the dorsal spines are remored, to slow plates; $p$, dorsal pore

Fignre 3. Rosuster alcundri Perrier. Part of clisk and two rays of : young specimen, dorsal view; $p$, torsal pore; $i, i$, large basal interradial plates; $m$, madreporic plate. The spimules are partly removed to show form of plates; $\times 3$.

Figure $3 a$. The same. Two of the dorsal plates with rosettes of spinules, $\times 16$.

Figure $3 b$. The sane. Two of the dorsal spinules more enlarged.

Figure 4. Astcrinides folium (Lïtk.) Dorsal riew of a six-rayed specimen, about natural size.

Figure 5. Elakiaster conicus Perrier. Under side of disk and jaw of the specimen on plate $i i i$, figure 4, Bahama Exjed.; spinules are removed from part of the plates; $j$, jaw-plate; $n, a$, adambulacral plates; $a^{1}, a^{1}$, adoral adambulacral plites, one with spines; $i n$, in 1 , interactinal plates; $o, o^{1}, o^{11}$, impaired interactinal plates; $p$, pit where a pedicellaria was seated. $\times 5$.

Figure 6. Porania austera Verrill. Type. Dorsal riew of portion of disk at base of rays; $s, s$, superomarginal plates; $i, i$. inferomarginal plates; $j, j$ their secondary row of spimules. $\times 5$.

Figure $6 a$. The same sperimen. Under side of a prortion of the disk and base of a ray. $\times 5$.

Figure 7. Henricia sexradiata (Perrier). Under side of a ray. Specimen from Balıma Expedition; $m$, inferomarginal plates; $i$, interactinals; a, adambulacrals; s. s, adambulacral spines. $\times 16$.

\section{PLATE XII}

Figures 1, 1a. Luidia altcrnata bicolor Verrill. Type. Dorsal and rentral views of a part of a ray. $\times 3$.

Figures $1 b$. The same. Section of a ray; diagramatic; $a$, a, ambulacral single ampullac; $p$, podia; $n p$, ambulacral plates; ad, adimbulacral plate and spines; $m$, marginal plate and spines; $p a$, dorsal paxille.

Figure 1c. The same. One of the marginal spines; the shaded fortion is chocolate-brown; the innshaded distal part is white. $\times 13$.

Figure 2. Astropecten nuttingi Verrill. Type. Dorsal side of proximal part of a ray. $\times 6$.

Figure $2 a$. The same specimen. Under side of portion of a ray. $\times 10$. From Bahama Expedition. Station 58.

Figure $2 b$. The same. Diagram of profile of a border of a ray. 
Figure $2 c$. The same. Dorsal side of a superomarginal plate $(m)$ and projecting border of the inferomarginal plates $(i, i)$ and bases of spines. $\times 13$.

Figure 2d. The same. One of the dorsal paxillary rosettes. $\times 16$.

Figure $\_e$. The same. Three rosettes more enlarged. $\times 24$.

Figure 3. Astropecten comptus Verrill. Type. (No. 3,514, N. Mus.) Dorsal view of portion of a ray. $\times 4$.

Figure $3 a$. The same specimen. Under side of portion of a ray. $\times 4$.

Figure 32. The same. One of the fasciolated grooves between the inferomarginal plates. $\times 10$.

Figure $3 c$. The same. 'l'wo of the dorsal paxillary rosettes. $\times 24$.

Figure 4. Prionaster elegans Verrill. Type. Under side of a part of the disk and base of a ray. $\times 41 \%$.

Figure $4 a$. The same specimen. Under side of a part of the disk and base of a ray. $\times 4 \frac{1}{2}$.

Figure $4 b$. The same specimen. Tip of a ray. $\times 6$.

Figure $4 c$. The same. One of the dorsal paxillary rosettes, enlarged.

Figure 5. Sideriaster grandis Verrill. Type. Under side of portion of a ray. $\times 4$.

Figure $5 a$. The same specimen. An adambulaeral plate and its spines. $\times 6$.

Figure $5 b$. The same. One of the dorsal paxillary rosettes. $\times 41 / 2$.

\section{Plate XIII}

Figure 1. Blatiaster conicus Perrier. Portion of the proximal part of a ray, under side; $a d$, adambulacral plates and spines; $i a$, interactinals; $m$, inferomarginals. $\times 10$.

Figure 1a. The same. Dorsal plates and papula after removial of spinules. $\times 12$.

Figure 1b. The same specimen. A superomarginal plate and adjacent dorsal paxillæ. $\times 10$.

Figure 1c. The same. Two of the papilliform pedicellarize $(p)$, much enlarged.

Figure 2. Linckin nodosa Perrier. Dorsal side of a ray. $\times 4$.

Figure 2 $a$. The same specimen. Ventral side of part of a ray. $\times 4$.

Figure 3. Ophidiaster alexandri Verrill. Type. Dorsal side of part of a ray. $\times 4$.

Figure $3 a$. The same specimen. Under side of part of a ray. $\times 4$.

Figure $3 b$. The same specimen. Under side of a portion of a ray with spinules removed to show plates; $a$, adambulaceral plites; $a^{1}$, adambulacral spines; $i, i$, interactinal plates, in three rows; $m$, $m$, inferomarginals; $m 1, m^{1}$, superomarginals. $\times 4$.

Figure 4. Chatuster nodosus Perrier. Portion of muler side of a ray; $a d$, adambulacral plites; $m$, marginal plate. $\times 16$.

Figure $4 a$. The same specimen. P'ortion of the dorsal side of the base of a ray. $\times 16$. 
Figure 5. Goniaster americanus Verrill. Portion of the under side of the disk, with the jaw. $\times 4 \frac{1}{2}$.

lignre 5a. The same. Dorsal plates, with fossate pedicellaria. $\times \geq 0$. Fignre 6. Odontaster hispidus Verrill. l'ortion of dorsal side of a ray'; $p$, dorsal parapaxilla; $m$, superomarginal plates; $v, v$, inferomarginal spines. $\times 6$.

\section{Piate XIV}

Figure 1. Pectinaster dispar Verrill. 'Type. No. 18,468. Part of muler side of a ray; plates 6 to $9 . \times 5$.

Figure 1a. The same specimen. Papnlarimm. $\times 15$.

Figure 1b. The same specimen. l'ortion of the dorsal side of a ray. $\times 5$.

Figure 2. Cheiraster mirabilis Perrier. Part of a ray, mder side. $\times 7$. Station 2, Bahama Expedition.

Fignure 3. C. echinulatus Perrier. No. 10,109. N. Mus. Part of disk, under side. $\times 8$.

Figure 4. Pectinaster gracilis Verrill. Sta. 238. Portion of under side of a ray. $\times 10$.

Figure 5. Cheiraster mirabilis Perrier. Flom station 34, Bahama Expedition. Part of disk and base of a ray, showing papularium. $X \overline{5}$.

Figure $5 a$. The same specimen. Portion of under side of a ray. $X 5$.

\section{PLATE XV}

Fignre 1. Pectinaster gracilis Verrill. Cotype. Young. Sta. 238. Part of under side of the disk showing one sutural pectinate pedicellariat between two interactinal plates. $\times 9$.

Figure 1a. The same specimen. Upper side of ristal portion of a ray, with spinules removed from dorsal plates. $\times 9$.

Figure 1b. The same specimen. Base of ray and papularium in early stage of development with only three pores. $\times 15$.

Figure 2. Pectinaster mixtus Verrill. Cotype. Distal part of a ray with the spinules removed from part of the plates. $\times 6$.

rigure 3. Pectinaster forripatus (Slarlen). No. 18,488. Papularium of a young specimen; $d$, dorsal pore. $\times 12$.

Figure 4. The same species, No. 18,488a, N. Mus. Papularium with the spinules removed from plates. $\times 1$..

Figure 5. Poraniella regularis Verrill. 'Type. No. 10,190. Nat. MIus. Under side of two rays and part of disk. $\times 6$.

Figure $5 a$. The same specimen. Dorsal side of a ray; $s$, superomarginal plates; $i$, inferomarginals; $j$, secondary row of spines on the latter.

Figure 5b. The sanı. Adambulacral spines of one plate; $f$, furrow-comb of three spines; $e, e$, two spines of actinal face.

Figure 6. Poranisea lepridus Ver. Type. One of the jaws. $\times 10$.

\section{Plate XVI}

Nigure 1. Astropecten americamus Verrill. No. 25,149. N. Mus. Under side of part of disk and a jaw, showing papilliform perdicellariæ $(P, P)$ on adambulacral plates. $\times 7$. 
Figure 1a. The same specinen. Part of dorsal side of a ray, near base. $\times \tau$.

Figure 2. A. aluplicatus variabilis (Lütken). Type. No. 2,08t, Yale Mns. Portion of a ray, th to 6 th plates, dorsal side. $\times 9$.

Figure $2 n$. The same specimen. Under side of portion of a ray. $\times 9$.

Figme 3. A. nitidus forcipatus Terrill. Type. No. 10,n6i, N. Mus. Portion of under side of a ray. $\times 7$.

Figure 4. Luiria flegens Perrier. No. 5,5os, Yale Mus. Portion of under side of al ray. $\times 7$.

Nigure $4 a$. The sane specimen. Portion of the dorsal side of a ray. $\times 7$. Plate XVII

Figure 1. Pcctinaster mixtus Verrill. Young, (No. 18,470). Dorsal side. $\times 3$.

Figure 2. Rosaster alexandri Perrier. Dorsal side. $\times 3$, off Havana. bahama lixpedition. Some plates are lacking.

\section{Plate XVIII}

Figure 1. Chciraster enoplus Verrill. Type. No. 7,455, N. MI us. Dorsal side; $3 / 5$ natural size.

Figure 2. C. planus Verrill. Type. No. 18,469, Nat. Mus. Dorsal riew. $\times 11 / 5$

\section{Plate X1X}

Figure 1. Luidia elegans Perrier. Young. Dorsal view. $\times 31 \%$. BaLama Expedition, station $6 \%$.

Figure 1. Astropecten nuttingi Ver., sp. nov. Type. Bahama Exped., tion, station $61 . \times 31 \%$.

\section{PLATE XX}

Figure 1. Astropecten nitidus forcipatus Ver, nor. 'Type, No. 10,067. Dorsil side. $\times 12 / 5$.

Figure 2. A. nitidus Ver. Type, No. 18,344, Nat. Mus. $\times 1$ \%/5.

$$
\text { PLATE XXI }
$$

Figure 1. Astropecten nutingii Ver., sp. nor. Type. Bahama Exped., sta. 64. Dorsal side. $\times 11 / \overline{0}$.

Figure 2. The same splecimen. Under side. $\times 1 \frac{1}{3}$.

\section{Plate XXII}

Figure 1. Astropecten comptus Ver. Type, No. 18,346, Nat. Mus. Dorsal side. $\pi / 10$ natural size.

Figure 2. A. duplicutus Gray. No. 10,989, Nat. Mus. Dorsil side. T/10 natural size.

\section{PLATE XXIII}

Figure 1. Astropecten duplicatus Gray. St. Thomas. From Lütken. Dorsal view. $\times 11 / 4$.

Figure 2. The same, var, variabilis (Lïtken). Cotype, from Lïtken. Ventral riew. $\times 1 \frac{1}{4}$. No. 2,084, Jale Museum. 


\section{Plate XXIV}

Wigure 1. Luidia barbadensis Perrier. Dorsal view. No. 10,449, N. Mus. $\times 14 / 5$.

Wiguro 2. Lubria clutlurata (Say). From Bermula. Dorsal view. $\times$. Plate XXV

Fignre 1. Cheiraster cohinulalus (Her.) Voutal side; $\times 2$.

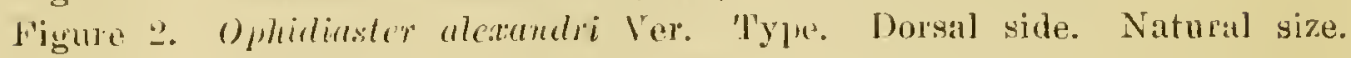
PLATE XXVI

Figure 1. Echinaster braziliensis M. and Troseh. Ventral side. Natural size. Specimen from Brazil.

Figure 2. Coscinasterias temuispina (Lam.) Var. Dorsil side of a sevenrayed, living, Bermuda specimeu under water; $: / 4$ natural size.

\section{Plate XXVII}

Figures 1, 2. Asterinides modesta Ver. Types. Tentral and dorsal viers of type specimens; $\times 3$.

Figure 3. Enoploputiria siderca Ver. Type. Ventral view of pat of the disk and a ray, with part of the spinules removed; $X 21 \%$.

Fignre $\ddot{a} a$. The same specimen. Dorsal view of a part of a ray and disk. Spinules are partly renoverl from the plates of the ray; $\times 21 \%$.

Figure 4. Coscinasterias temispina. Dorsal view of a living specimen under water. Abont natural size.

\section{PLATE XXVIII}

l'igure 1. Solaster caribaus lrer. Dorsal side of a small specinen; somewhat enlarged.

Figure 1a. The same specimen. Ventral sicle; more cnlarged.

Eigure 2. Asterinides folium (Lïtk.). Dorsal side; $\times 4$.

Nigure :3. Linckia guildingii Gray. Dorsal side of a young specimen, repproducing rays, after autotomy. Natural size.

Figure 4. Peltaster milurioscusis Storm $=$ P. hebes Verrill, type. Ventral side; $2 / 3$ nat. size.

Figure 4a. The same specimen. Group of plites on the dorsal sida of the disk, with most of the granules remover. Afuch enlarged.

\section{PLATE XXIX}

Figure 1. Linclia nodosa Per. Dorsal side; $X 1 \%$.

Figure 1a. The same specimen. Ventral sille; $X 11 \%$.

Figure 2. Fithaster sentus V. (?) Young. About natural size. Ballama Experlition. 


\section{SISTEMATIC INDEX}

The references are to formal descriptions. Synonyms are not included

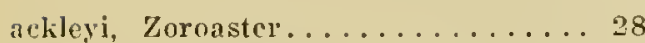

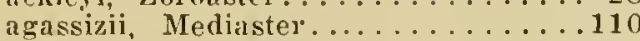

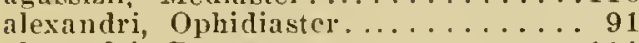

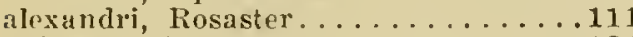

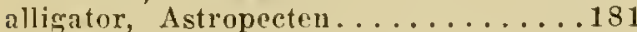

alternata bicolor, Luidia.........203

alternata, Luidia..............................

americanus, $A$ stropecteil . . . . . . . . . 184

innericanus, Goniastr1............104

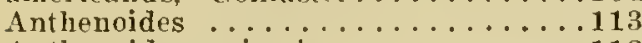

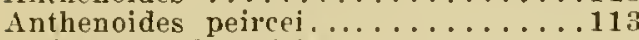

antillarum, Henricia ............. 46

antillensis, Astropecten.........179

articulatus, Astropecten............. 159

articulatus dubius, Istropecten .....165

Asteridae ...................14

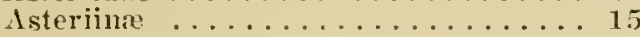

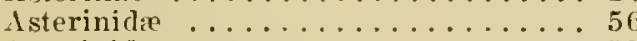

Asterinides ................. 58

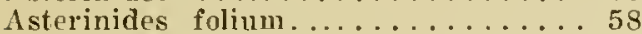

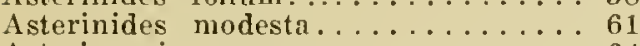

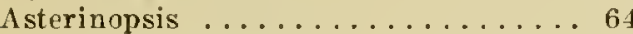

Asterinopsis lymani............ 64

Asterinopsis pilosa.............. 64

Asterioidea .................... 8

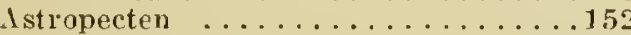

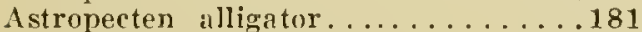

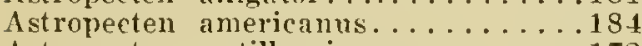

Astropecten antillensis....................

Astropecten articulatus........... 159

Astropecten articulatus dubins...... . 165

Astropecten brazilicnsis.................

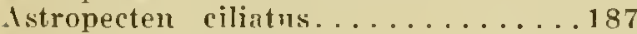

Ist ropecten ciugulatus............17

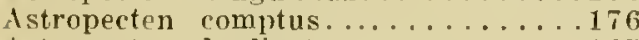

Astropecten duplicatus.............. 16

Astropecten nitidus............. 179

Astropecten nitidus forcipilis....... 180

Astropecten nuttingi..........................

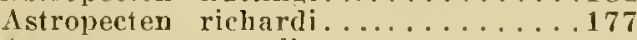

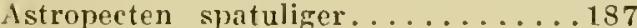

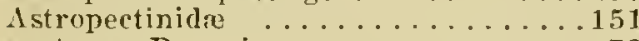

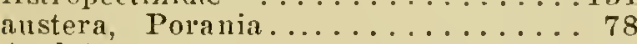

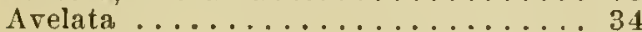

barbadensis, Luidia...........205

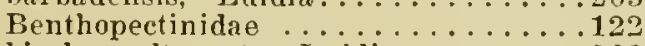

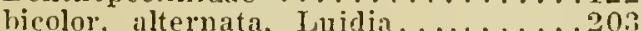

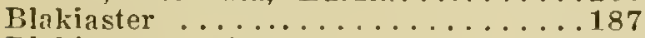

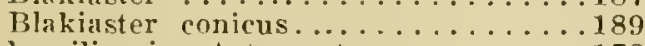

braziliensis, Astropecten........... 17 .

hraziliensis, Echinaster........... 41

briareus, Coronaster.................. 31

calibbreus, Pterastcr.......... 82

ra ribbous, Solaster................ 54

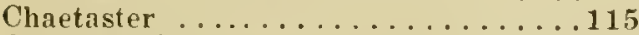

Chatasteridae ....................... 115

Chataster longipes...................... 117

Chataster nodosus................. 116

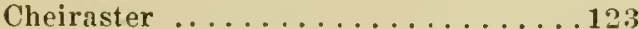

Cheiraster echinulatus. . . . . . . . 129

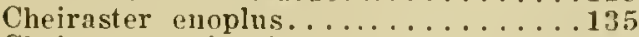

Cheiraster mirabilis............124
Cleiraster mirabilis coronatus......127

Cheiraster planus...............................

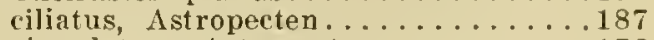

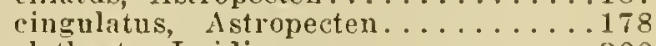

clatlirata, Luidia...............................

comptus, Astropecten ...........176

conicus, Blakiaster............... 189

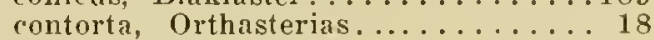

convexiuscula, Luidia ............ . . 207

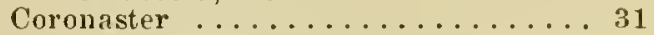

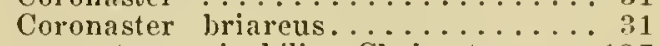

coronatus, mirabilis, Cheiraster....127

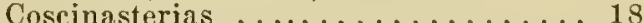

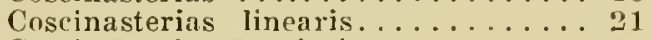

Coscinasterias temuispina.........

dentatus, Plinthaster.........................

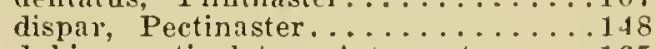

dubius, articulatus, Astropecten . . . 165

duplicatus, Astropecten...........165

Echinaster ....................... 35

Fchinaster braziliensis.......... 41

Fichinaster echinophorus.......... $4:$

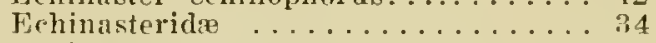

Echinaster modestus. .............. 43

Echinaster sentus.............. 36

Echinaster spinulosus. . . . . . . . . . 40

echinophorus, Echinaster........... 42

echinnlata, Poraniella.......... 73

echinulatus, Cheiraster........... 129

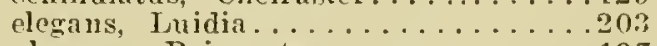

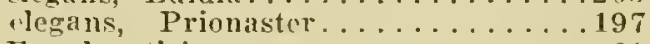

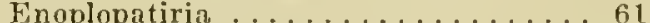

Fnoplopatiria narcinata......... 62

Enoplopatiria sirlerea ............... 6.3

enoplus, Cheiraster.............. 1i5

fascicularis, Leptasterias. . . . . . . . 22 floridie, Ophidiaster................. 90 folium, Asterinides............. 58 forcipatus, nitidus, $A$ stropecten..... 180

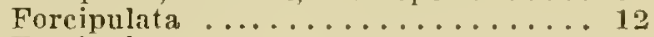
Forcipulosa ..................... 12

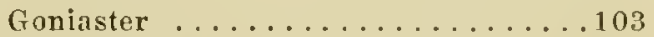

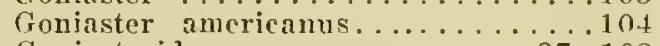
Goniasterida ............87, 102

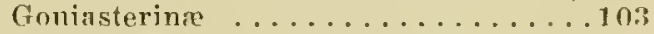

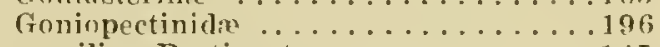
cracilis, Pectinaster.............. 145 gracilis, Stephanasterias.......... 25

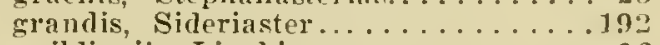

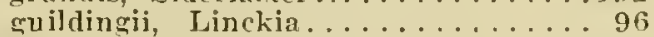
guildingii, Ophidiaster........... 90

hartii, Ieptasterias........... 23 liebes, Stephanasterias........... 26

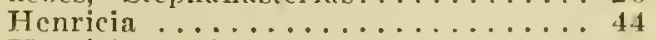

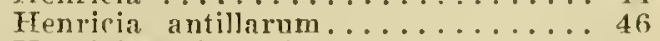
Henricia microspina............448

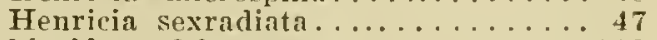

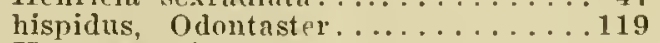
Hymenasterina ............. 82 
internedius, Plutonaster........196

Forethrasteridit ............ 54

Leptasterias .............. 22

Leptasterias fascicularis.......... 22

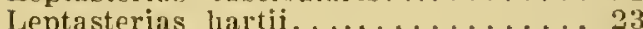

Leptasterias mexicana............. 24

Leptogonasterinae .............113

Linckia ................. 92

Jinekia guildingii............ 96

Linckia nodosa............... 9 .

linearis, Coscinasterias.......... 21

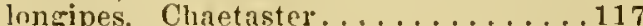

Topliaster ................... 50

Iophaster radians............ . 51

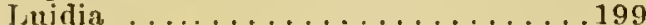

Luidia alternita.............201

Huidia alternata bicolor..........203

lunidia barbadensis............205

Luidia clathrata.............200

Luidia convexiusculiı . . . . . ..207

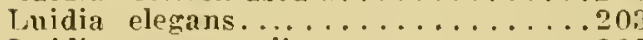

Luidia maregravii............208

Luidiaster ................ . 149

Iuidiidæe ................. 198

Jymani, Asterinopsis.......... 64

maregrarii, Luidia.......... . 208

Marginaster .............. 75

Marginaster pectinatus.........76

inarginata, Enoplopatiria......... 62

Mediaster ..............................

Mediaster agassizii............110

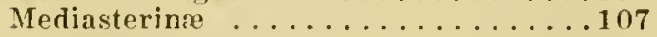

Mediaster pedicellaris. . . . . . . . . 109

mexicana, Leptasterias............ 24

microspina, Henricia...........48 48

mirabilis, Cheiraster.............. mirabilis coronatus, Cheiraster.....127

mixtns. Pectinaster.............140

modesta, Asterinirles............. 61

modestus, Fichinastrr..........

Narcissia . . . . . . . . . 97

Narcissia trigonaria.......... 97

nitidus, Astropecten...........179

nitidus forcipatus, Astropecten.....180

nodosa, Linekia............... 9:

nodosus, Chaetaster............116

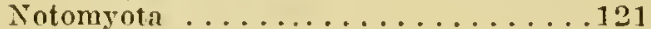

nuttingi, $\Lambda$ stropecten ............. 181

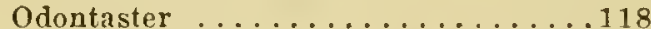

Odontaster hispidus............... 119

Odontasteridae .................... 118

oligoporus, Pectinaster.......... 147

Ophidiaster ................ 89

Ophidiaster alexandri............ 91

Ophidinster floridre............. 9n

Ophidiaster ruildingii............ 90

Ophidiasteridre................. 88

Oreaster .............. 99

Oreasterirlæ ................. 98

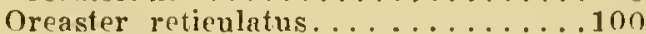

Orthasterias ................... 15

Orthasterias contorta............... 18

Orthasterias subanqulosit........ 16

palmatus, Remaster........... 55

Paxillosa ...................150

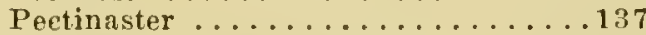

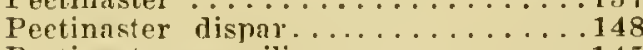

Pectinaster rracilis............... 145

Pectinaster mixtus. ........... 140
Pertinaster oliroporus...........147

Peetinaster vincenti............139

peetinatus, Marginaster.......... 70

pedicellaris, Nediaster............109

Pedicellaster

Pediceltasteridie................... 30

Pedicellaster pourtalesi.......... 32

peircei, Anthenoides...........112

Phanerozona ...........83,86

pilosa, Asterinopsis.............

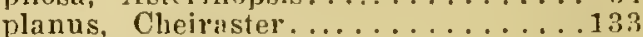

Plinthaster dentatus..............107

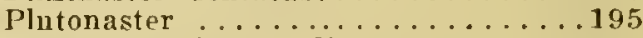

Plutonaster intermedius.............

Porania austera............ 78

Poraniella ................ 68

Poraniella echinulata............. 79

Poraniella regularis.............. 70

Poraniidae .............. 68

pourtalesi, Pedicellaster.........

Prionaster ................. 197

Prionaster elegans.............197

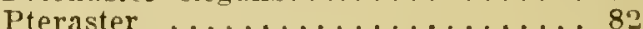

Pteraster caribbrus............ 89

Pterasterida $\ldots \ldots \ldots \ldots \ldots \ldots \ldots \ldots .80$

Pternsterine $\ldots \ldots \ldots \ldots \ldots \ldots \ldots$. 82

radians, Lophaster...........5 51

regularis, Poraniella............. 70

Remaster ................. 55

Remaster palmatus............ 55

reticulatus, Oreaster............ 100

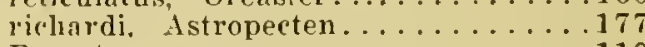

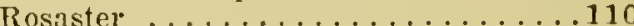

Rosaster alexandri............111

sentus, Echinaster.............. 30 serpentarius, Thyraster........... 4 sexradiata, Henricia............. 47 siderea, Enoplopatiria...........63

Sideriaster ................ 191

Sirleriaster guandis. . . . . . . . . 19.3

Sirleriaster vestitus. . . . . . . . . 19:

sladen, Stewnaster............ . rio

Solaster ..............

Solaster caribbais................. 54

Solasterida

spatuliger, istropectein ... . . . . . 187

Spinulosa .................

spinulosus, Echinaster........... to

Stecnaster sladen............. 65

Stemaster wesseli.............. 66

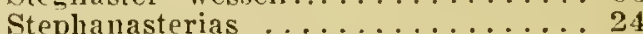

Stephanasterias gracilis.......... 25

Stephanasterias hebes............ 26

subangulnsa, Orthasterias.......... 16

Subgracilis .......................

tanuispina, Coscinasterias. . . . . 19, 20 Thyraster serpentarius........... it trigonaria, Narcissia............. 97

Valrulnsa ............... 87

Tarisbilis $\ldots \ldots \ldots \ldots \ldots \ldots \ldots \ldots \ldots . \ldots \ldots$

Velata....................... 80

restitus, Sideriaster.............. 19

rincenti, Pectinaster.............. 139

wesseli, Stegnaster.........66 66

Zoroaster ............... 27

Zoroaster ackleyi............... 28

Zoroasteride .............. 27 


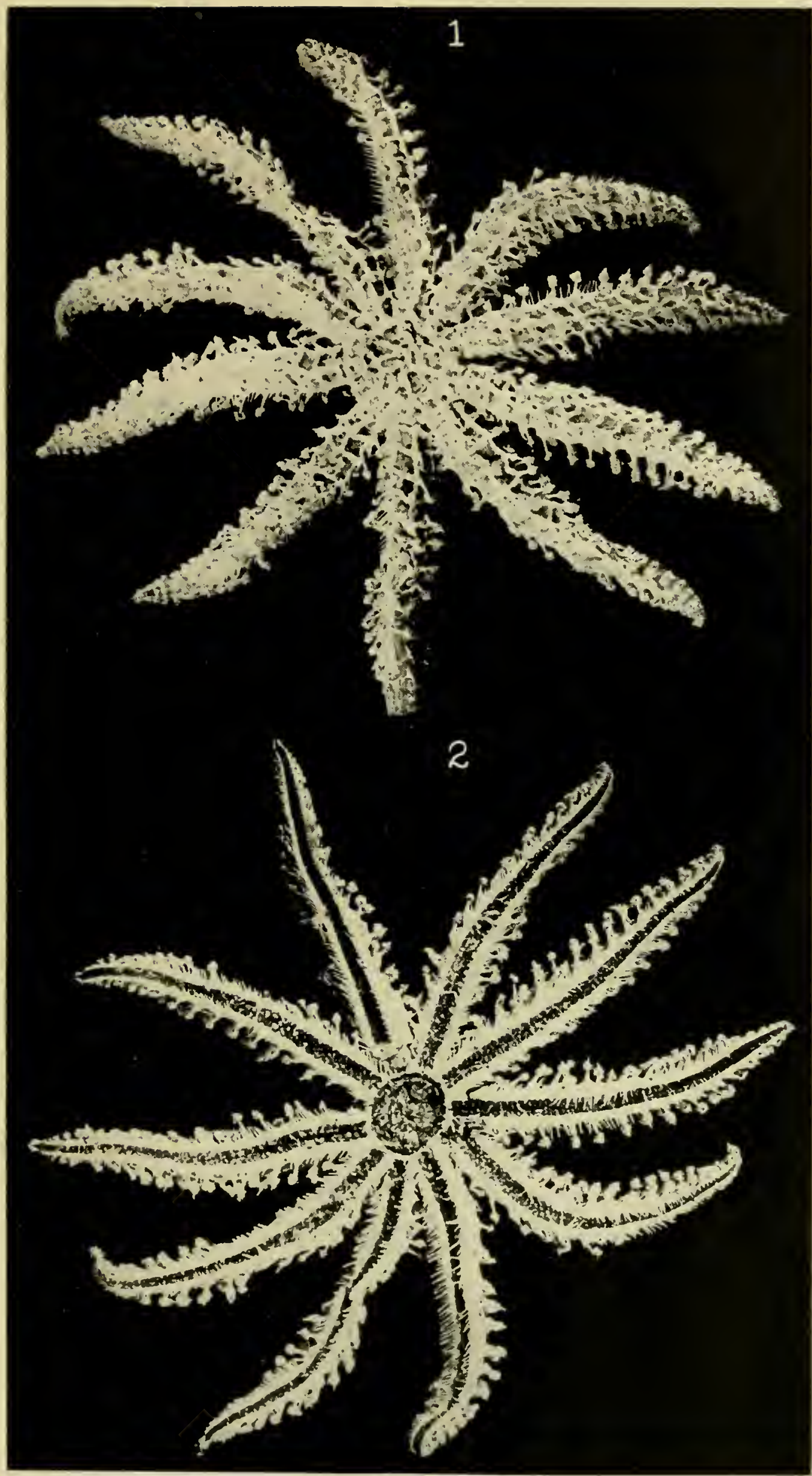

A. II. Terrill phot. 



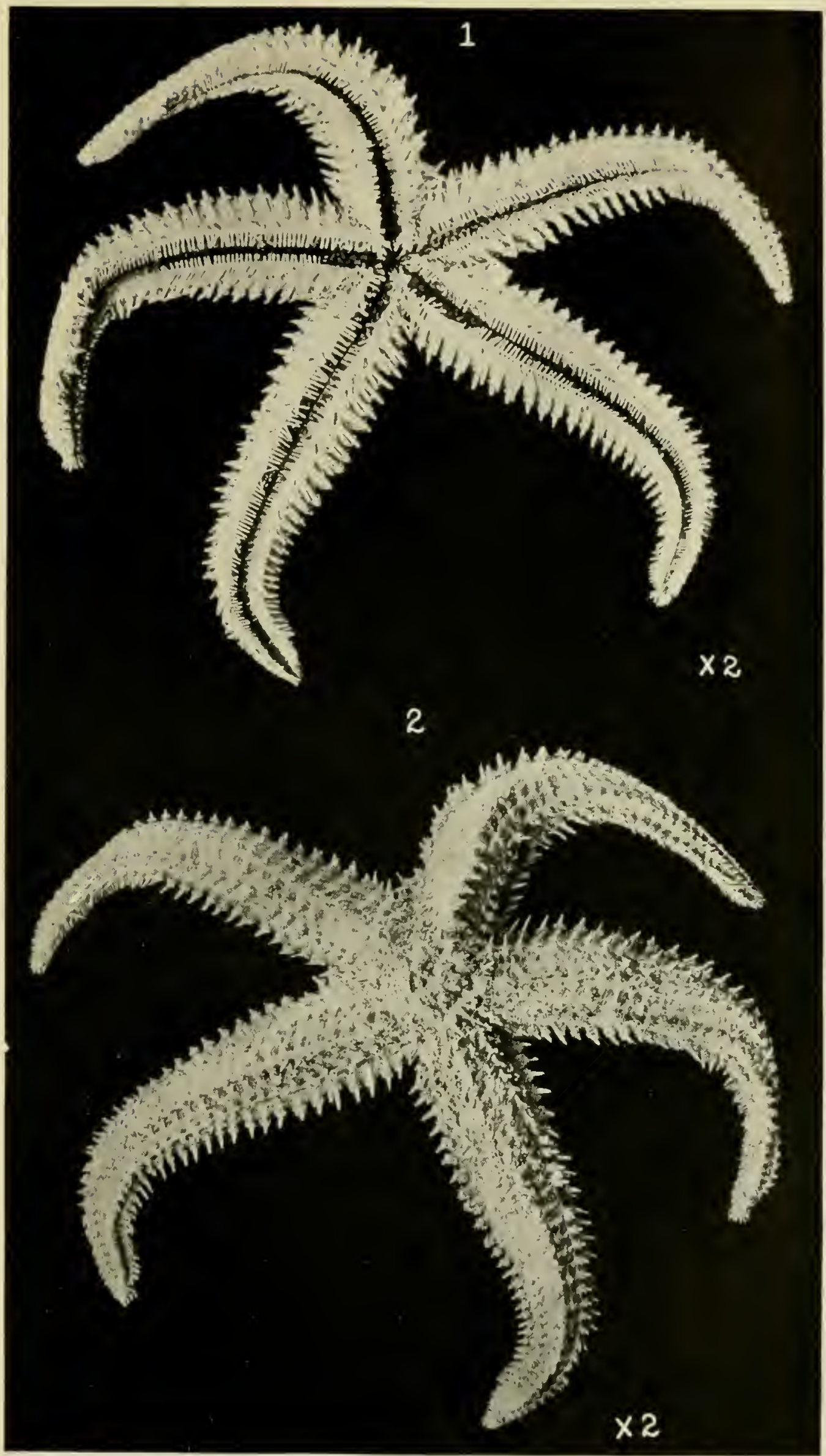

1. II. Terrill whot

WEST INIOIAN STARFISHES 



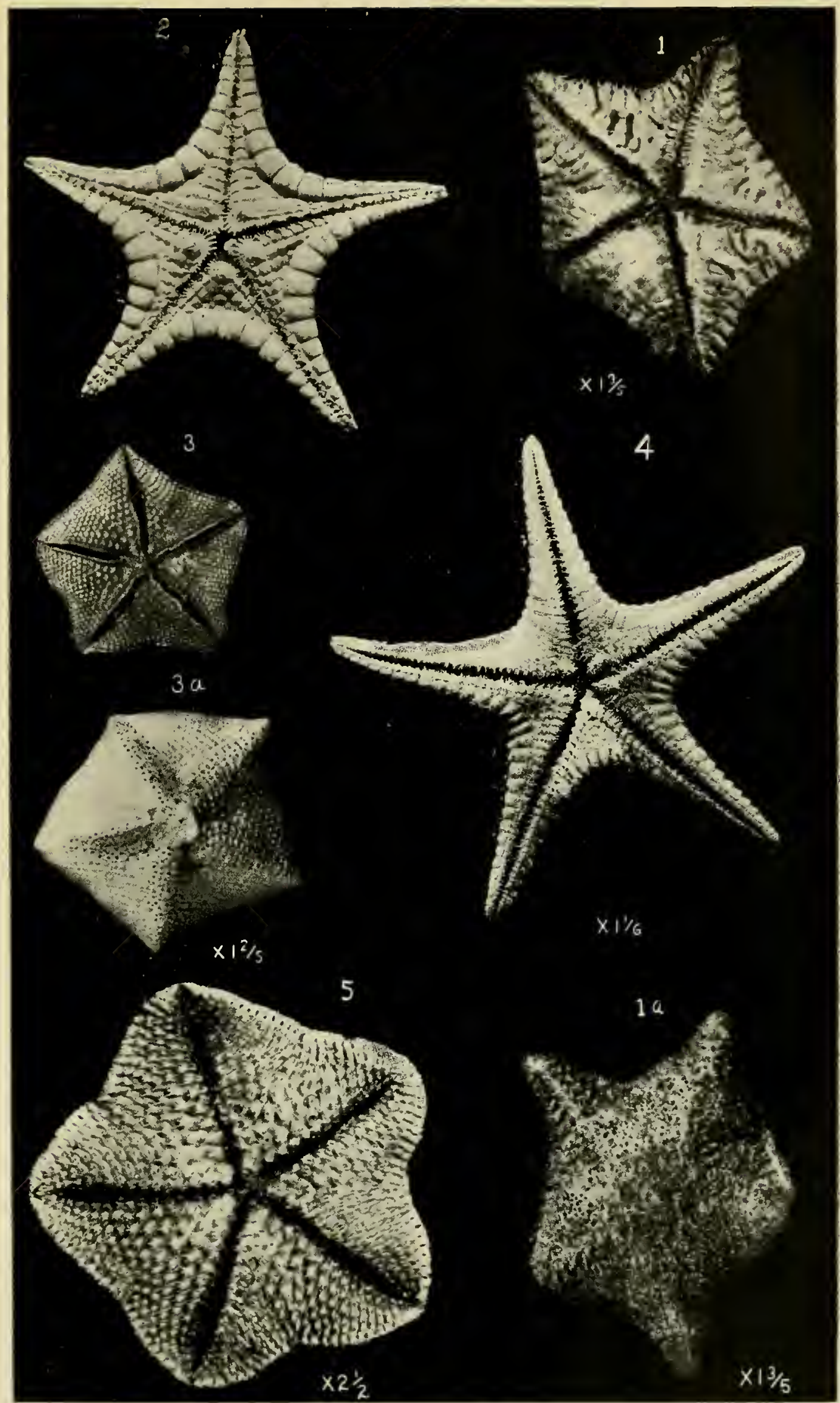

A. H. Verrill phot.

WEST INDIAN STARFISHES 



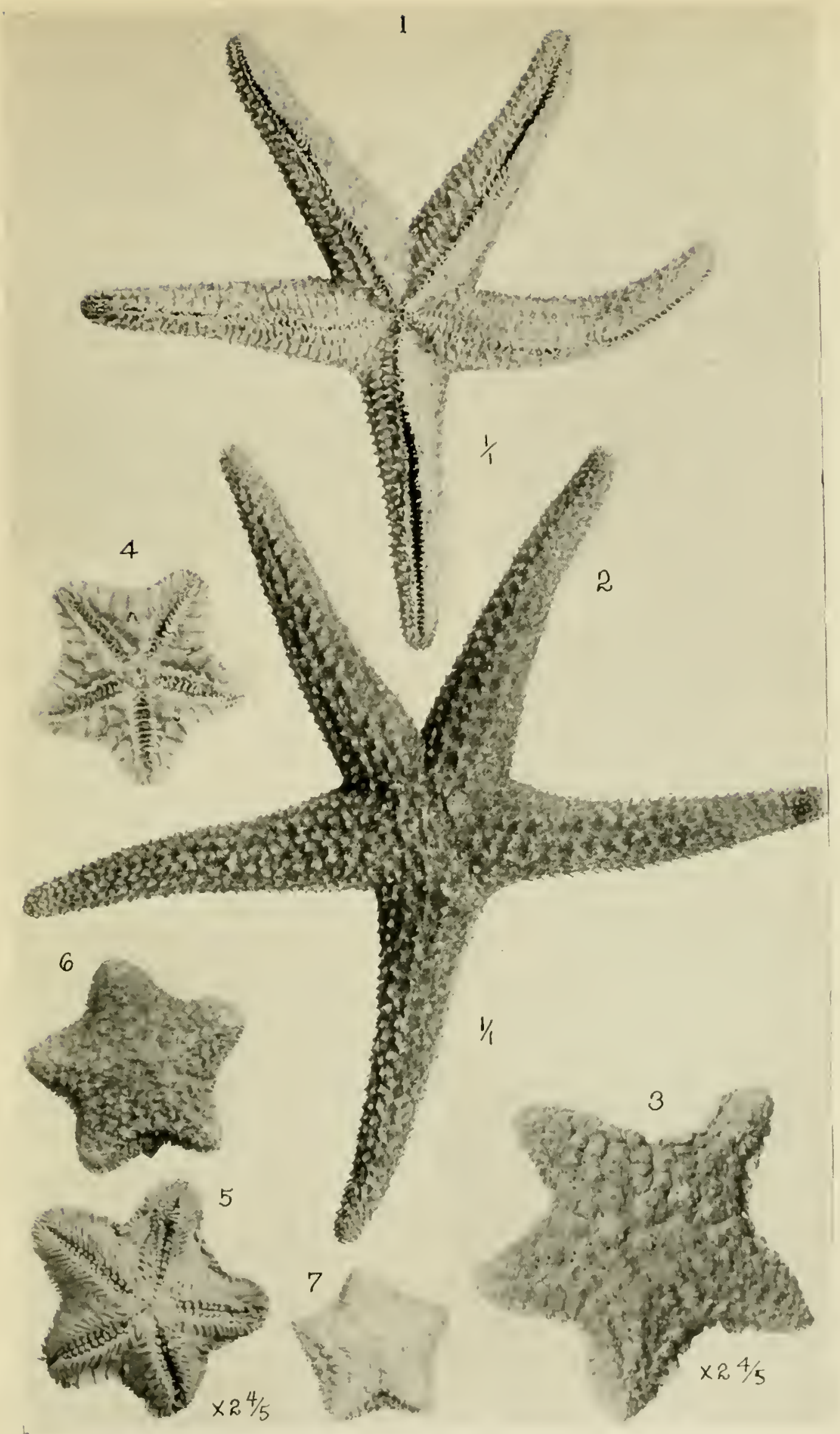

A. II. Herrill mhot.

WEST INIDAN STARFISHES 


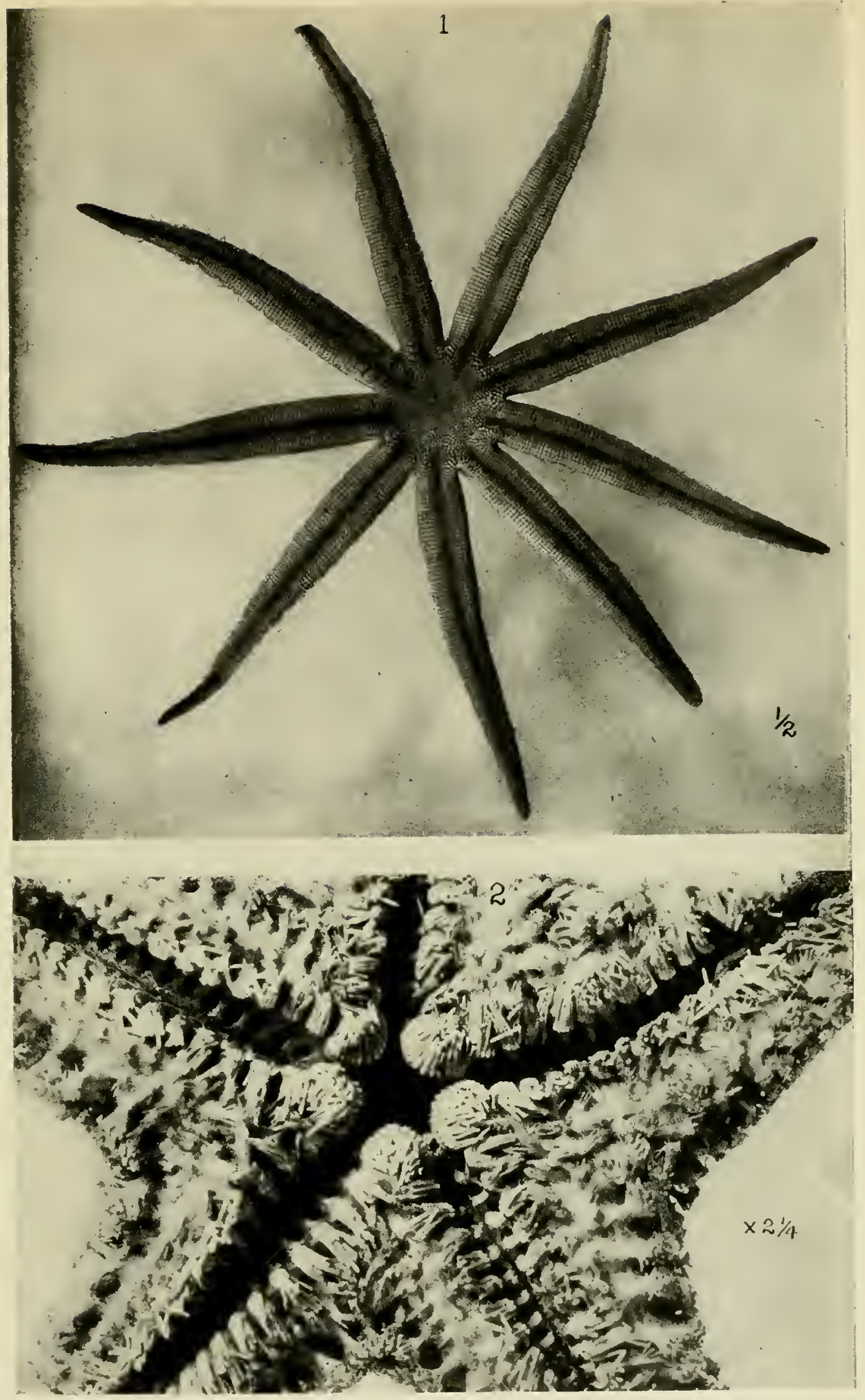

A. II. Terrill phet.

WEST INIIAN STARFISHES 



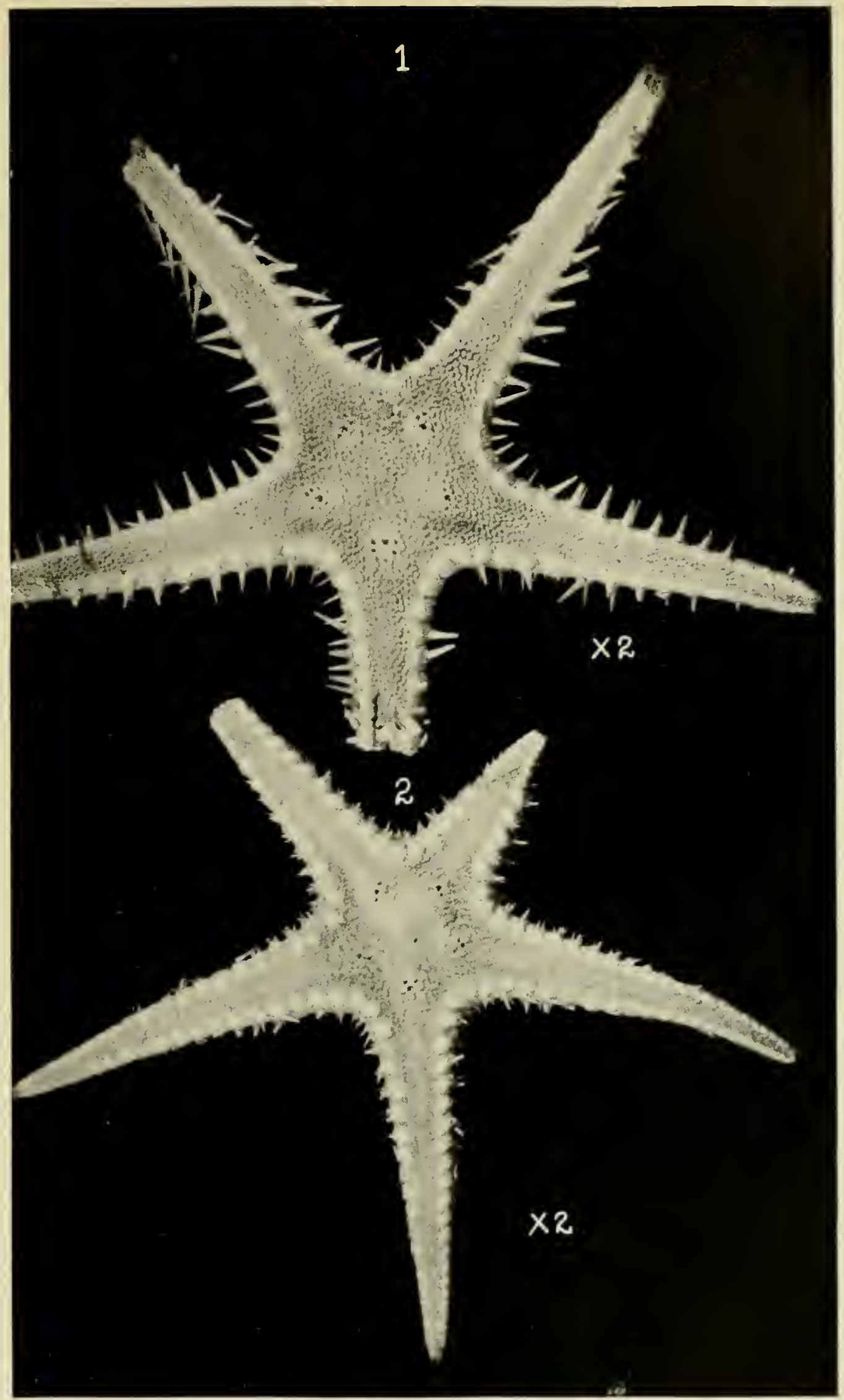

A. II. Terrill phot

WEST INOIAN STARFISHES 



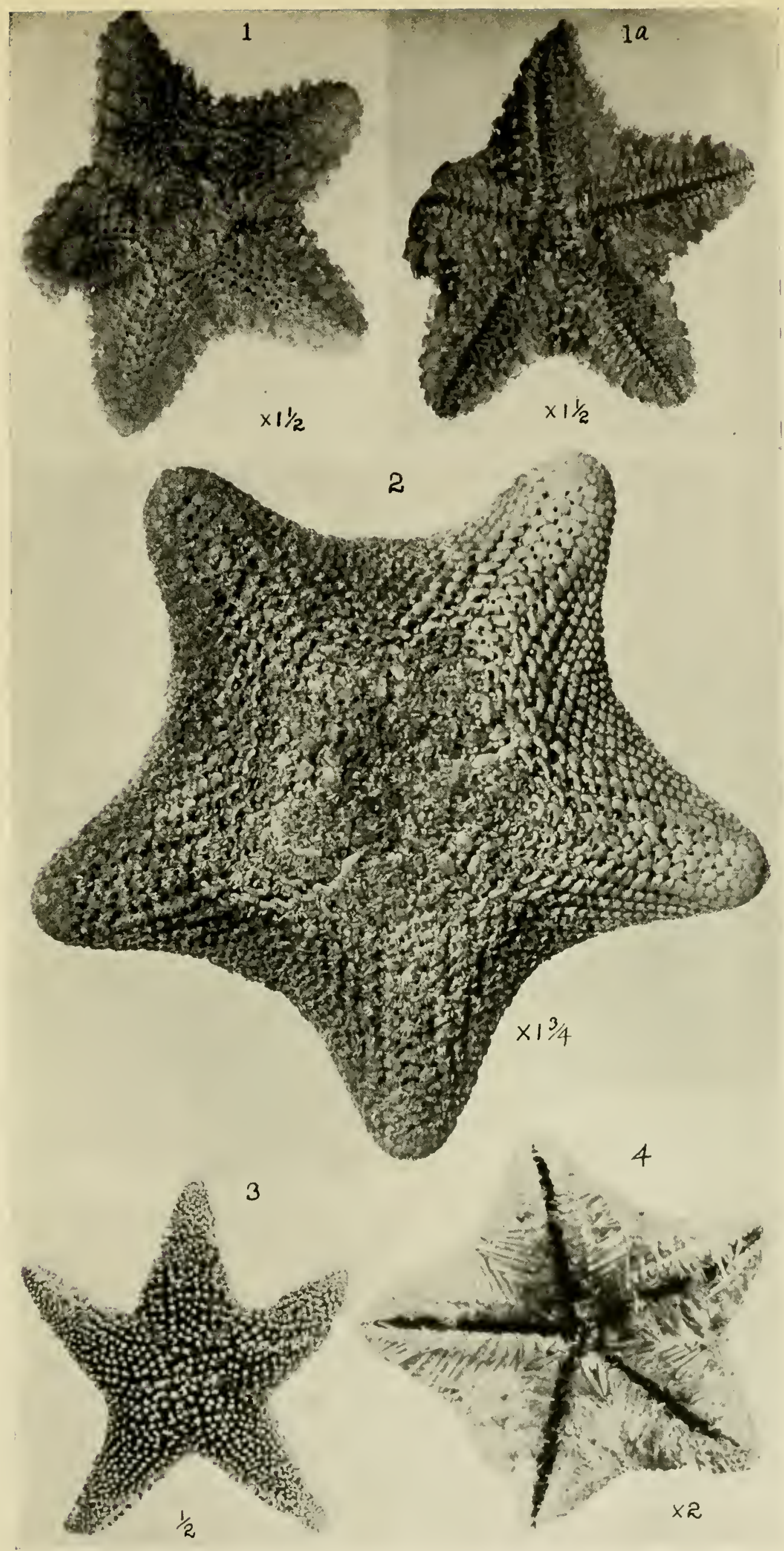

A. II. Verrill phot.

WEST INDIAN STARHISHES 



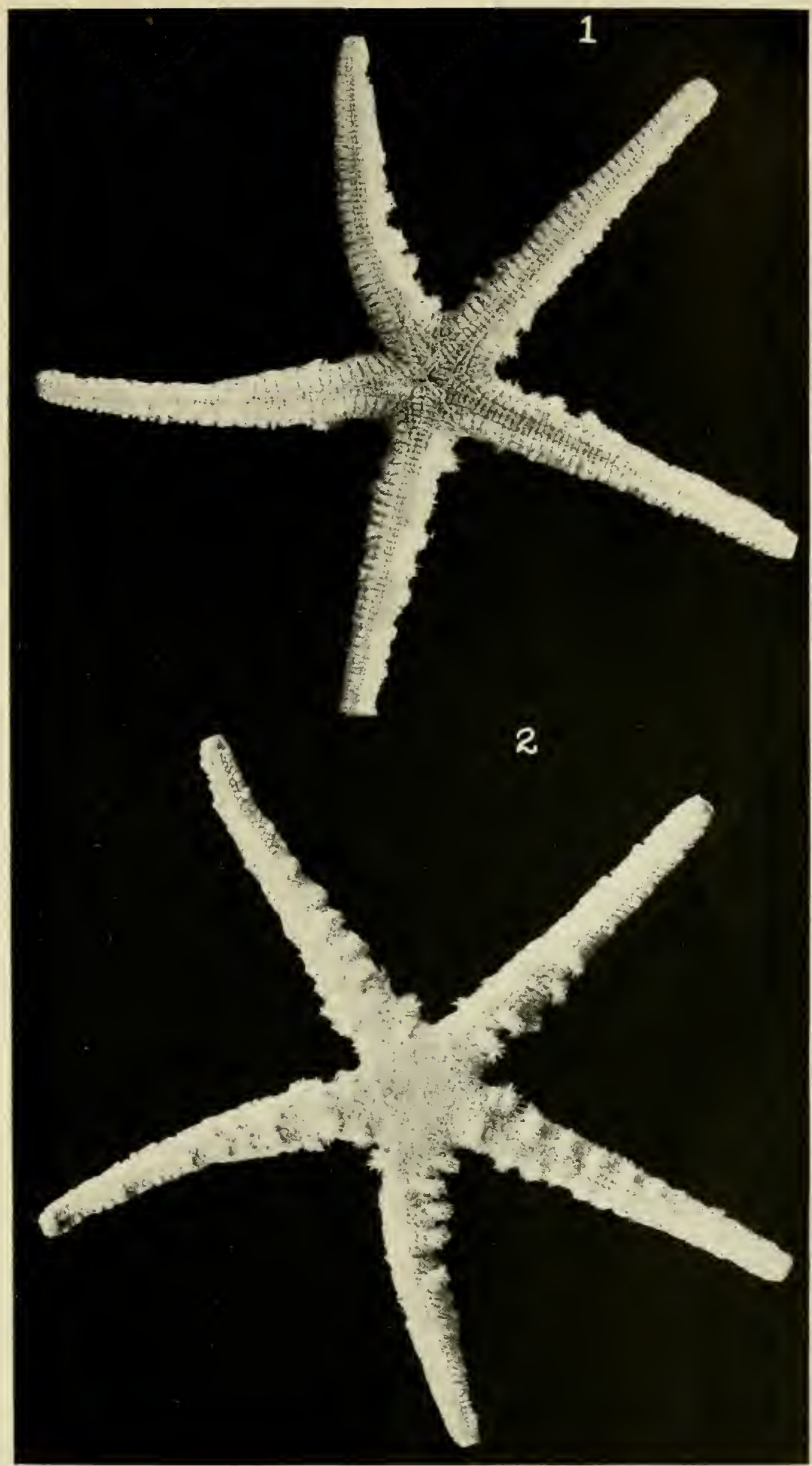

A. H. Ferrill phot.

WEST INDIAN S'TARFISHES 



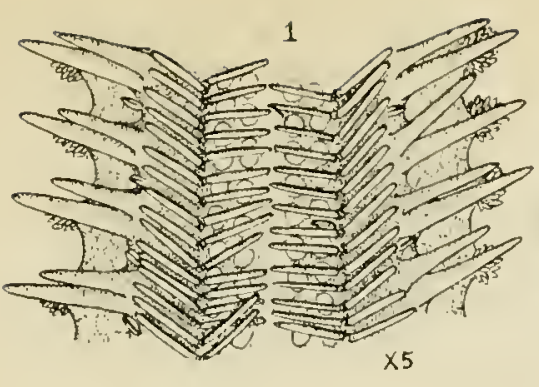

$1 a$
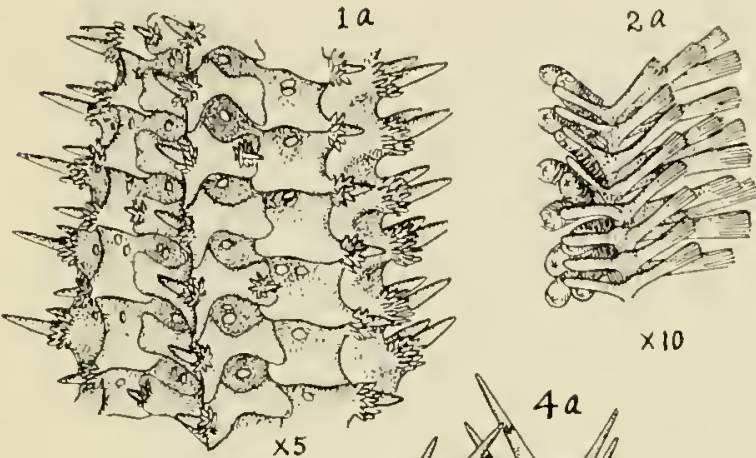

$\times 10$

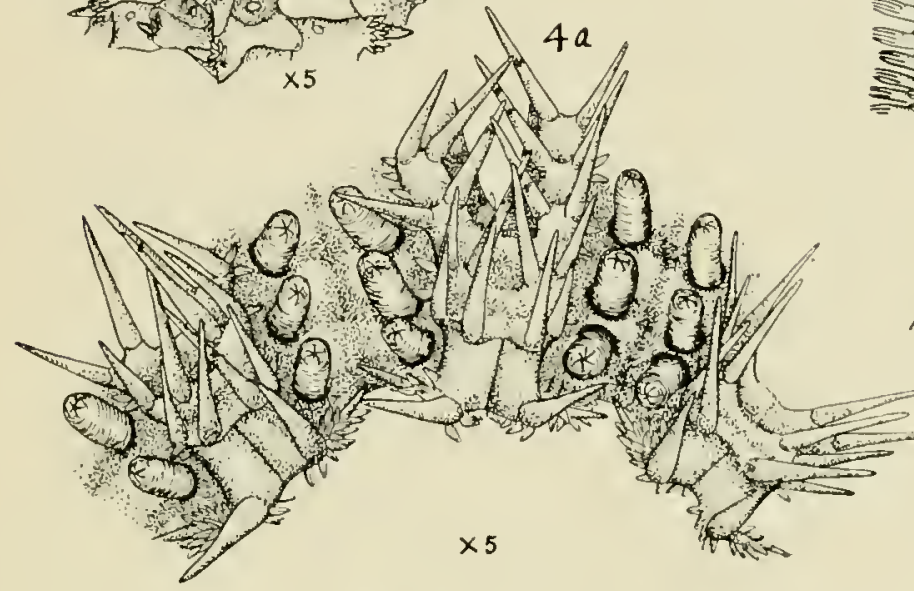

\section{4}

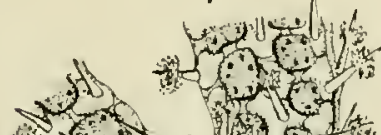

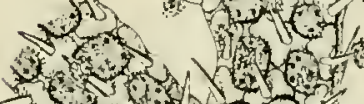

ond

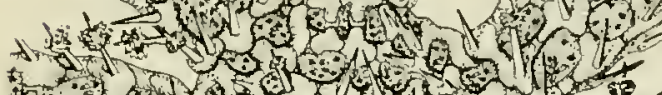

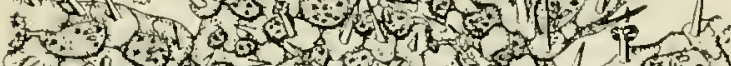

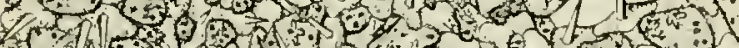

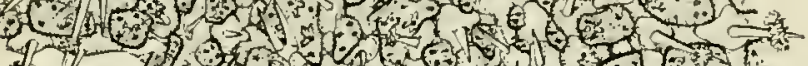

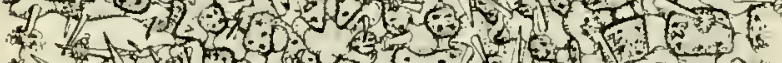

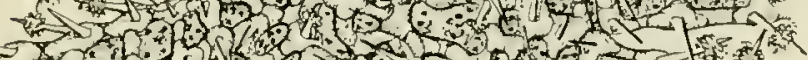

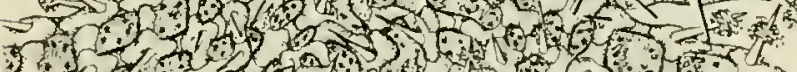

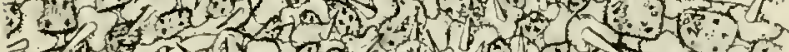

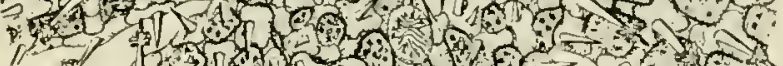

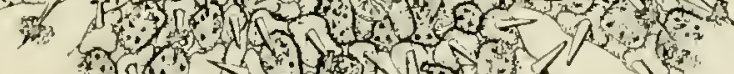

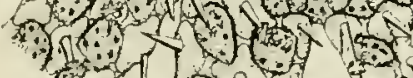
(5)

A. II. Trmill del.
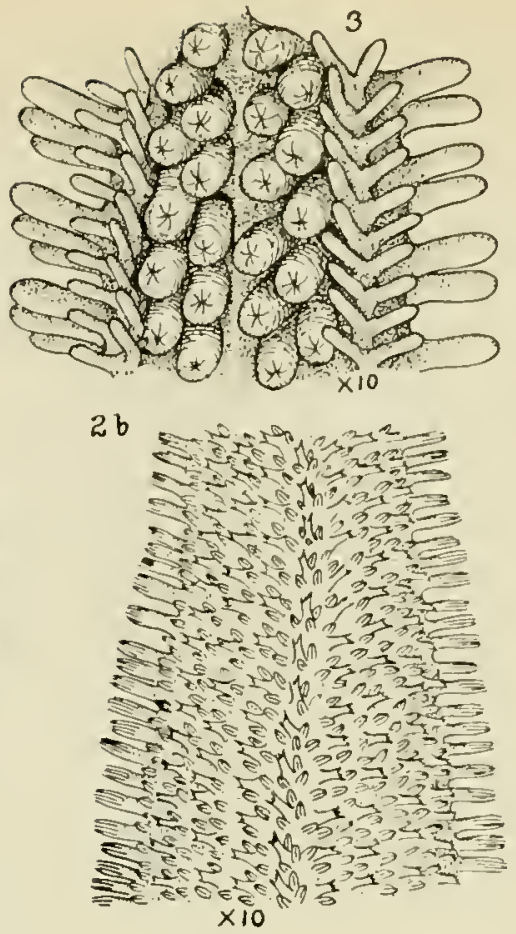

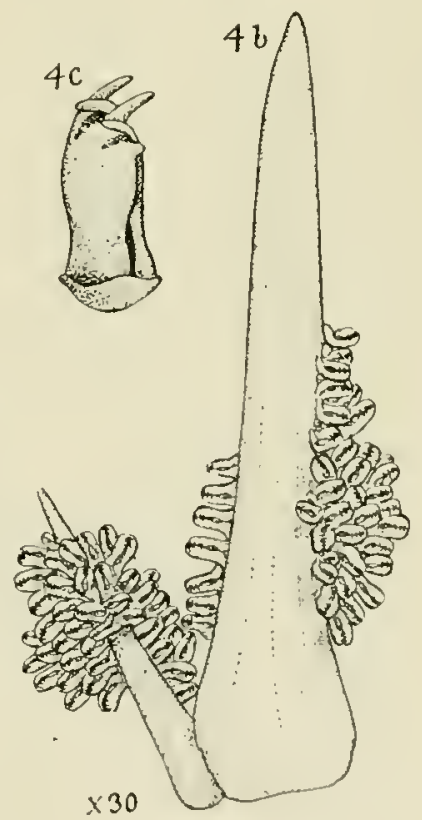

WEST INDIAN S'TARFISHES 


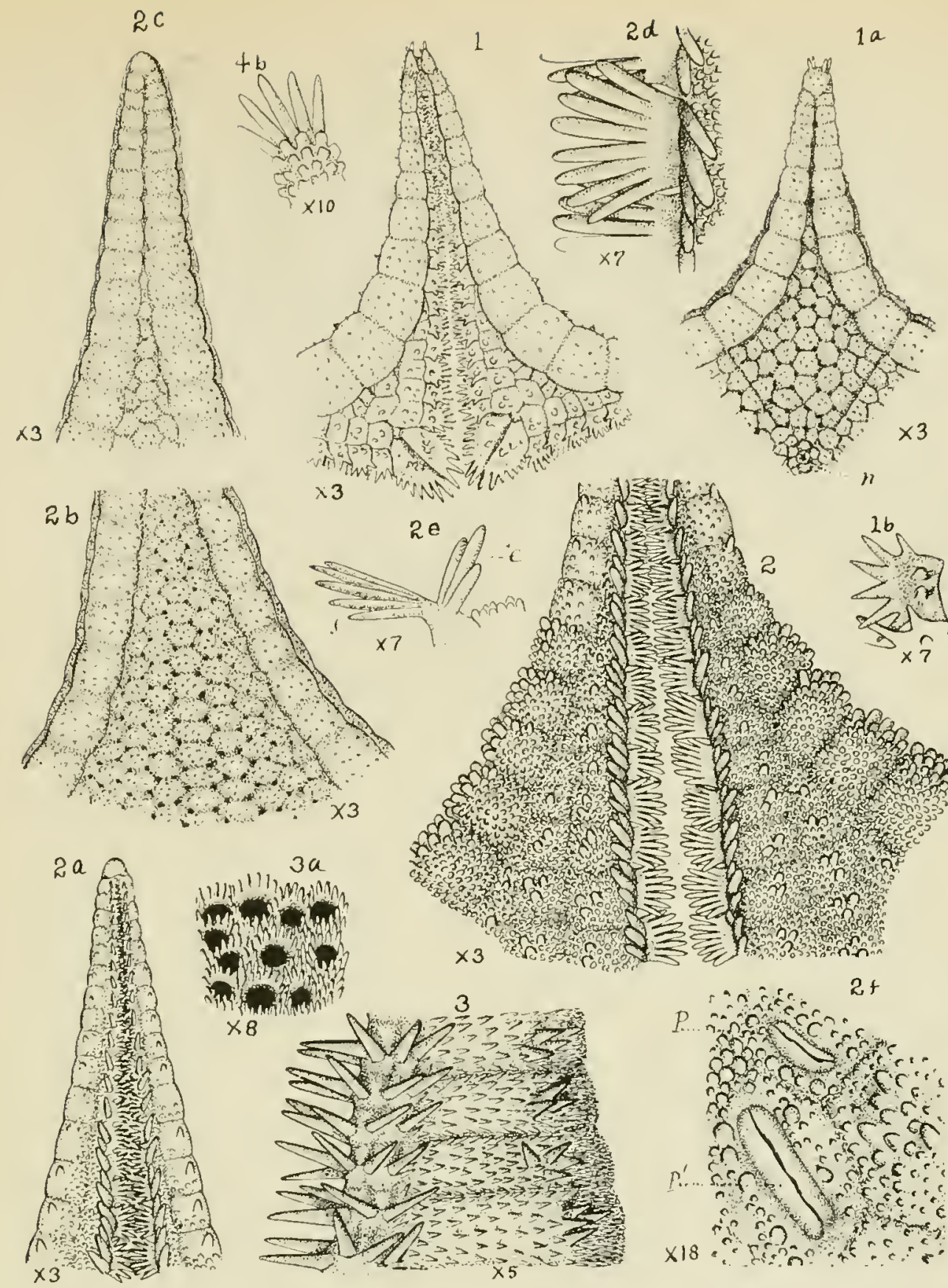


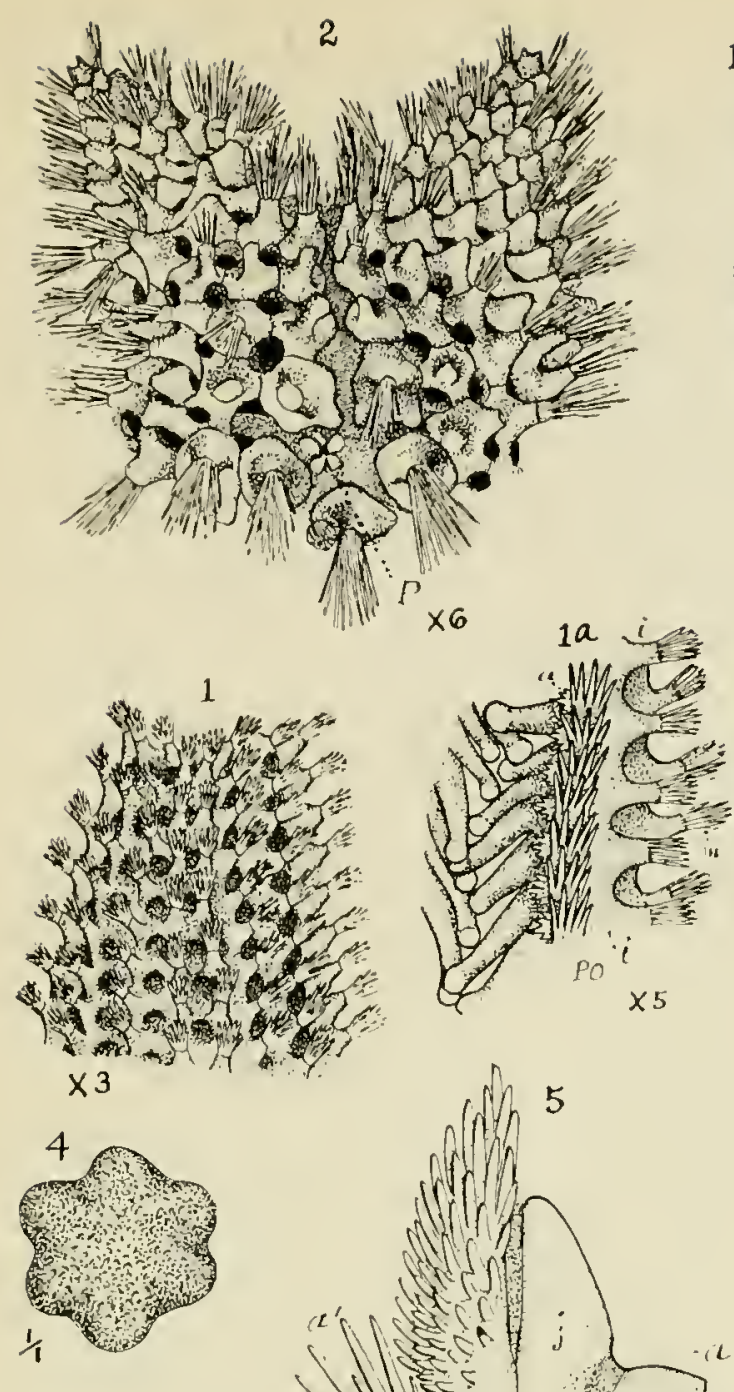
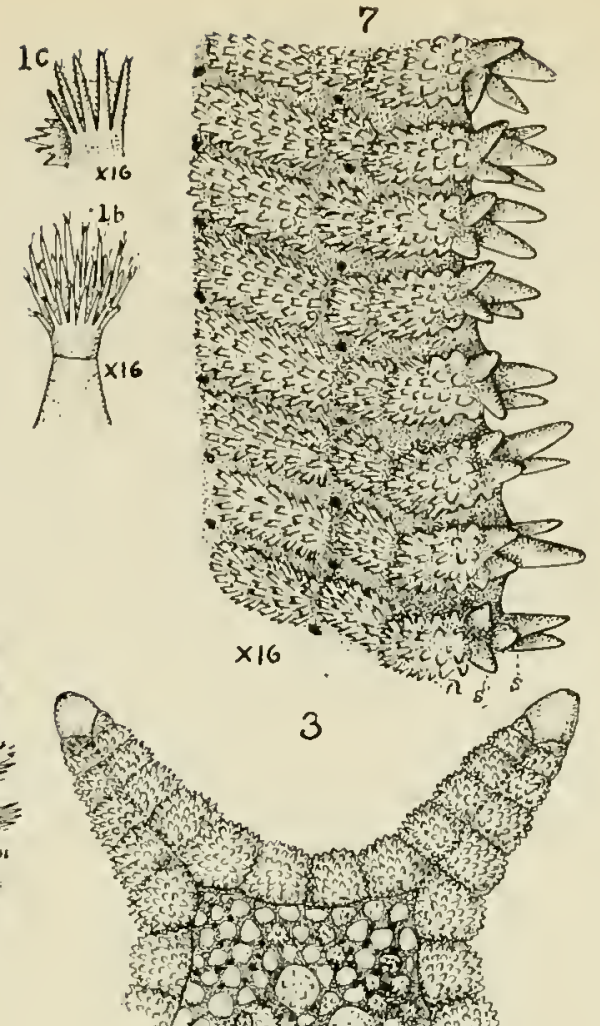

3

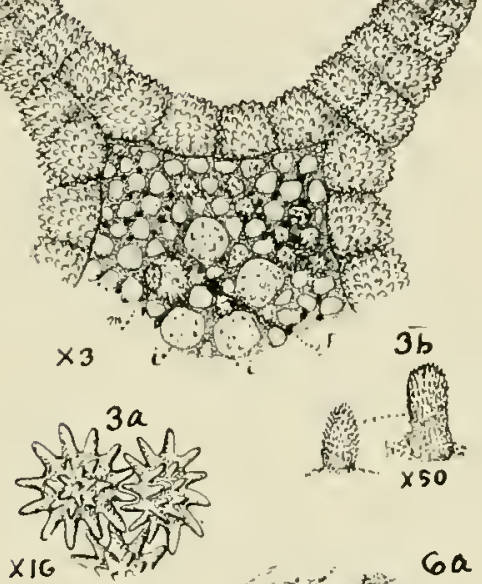

1114
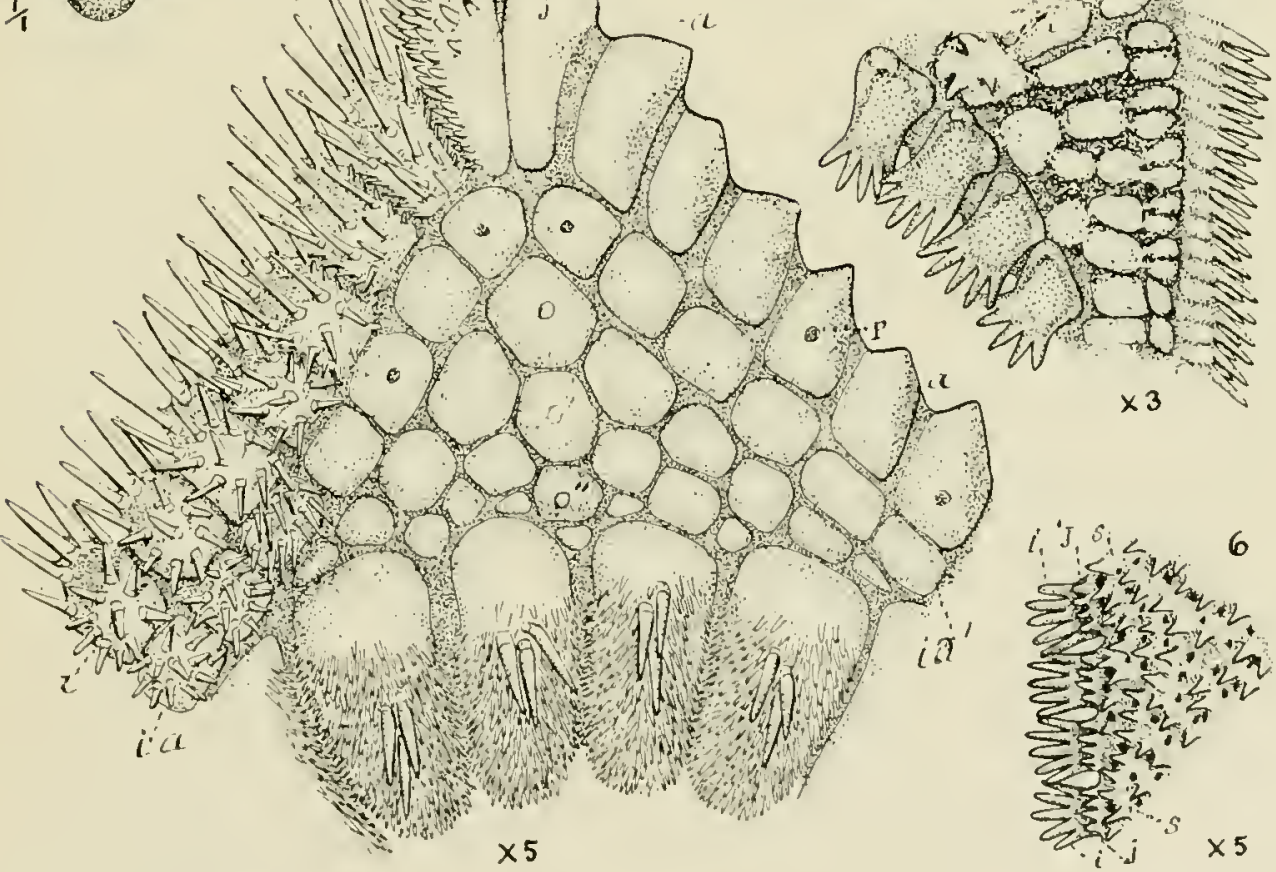

A. II. Terrill del.

WES'T INDIAN STARFISHES 

PLATE XII

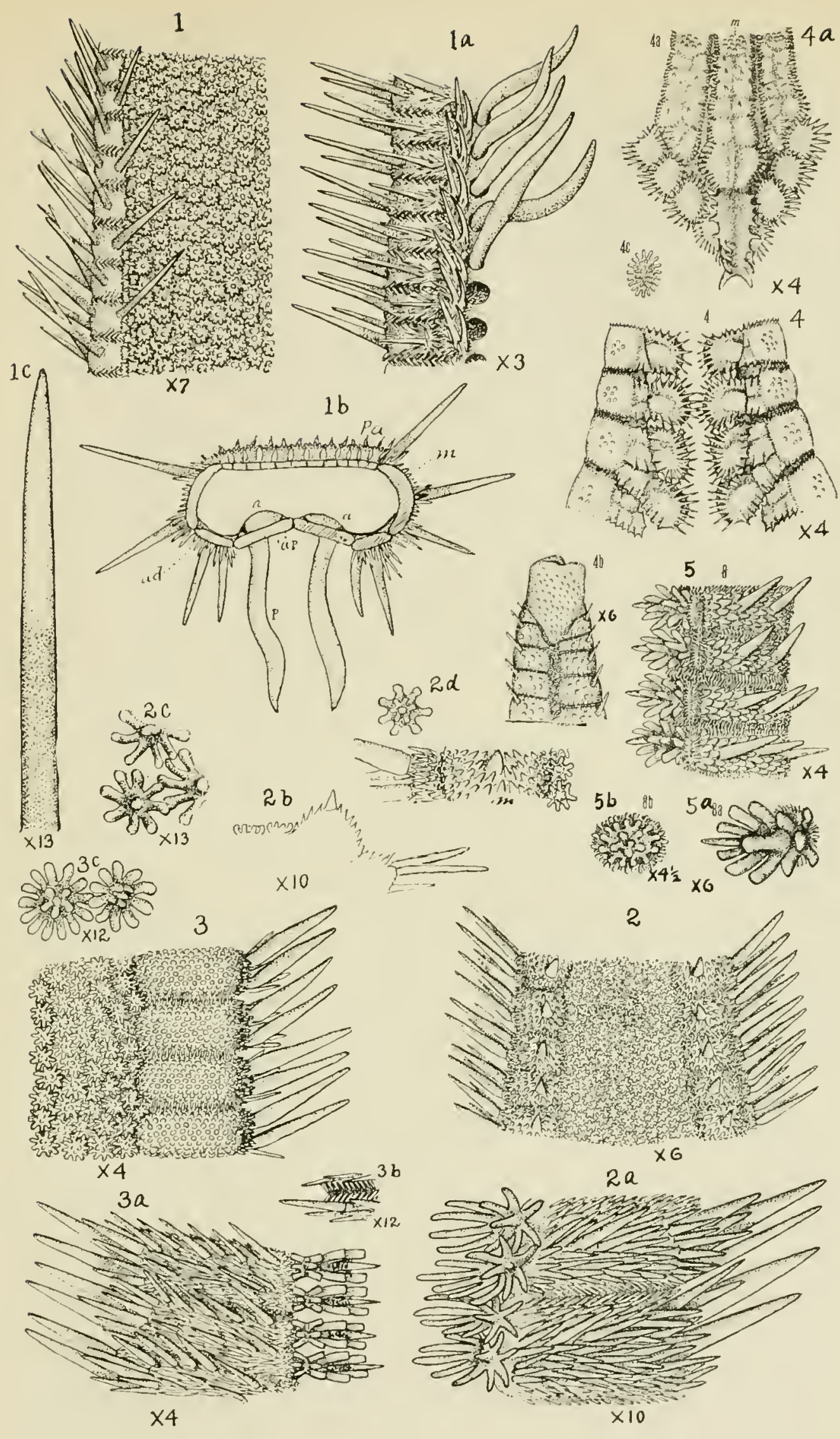

1. II. Terrill det.

WEST INUIAN STARFISHES 

2.

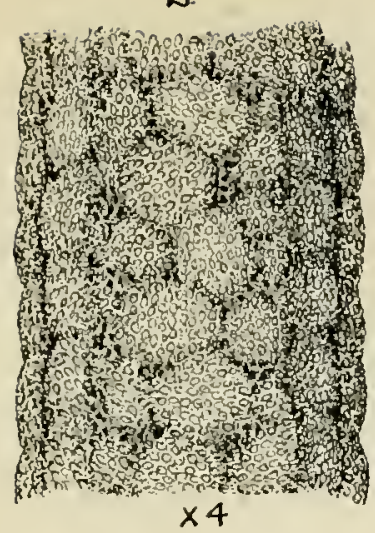

$3 a$
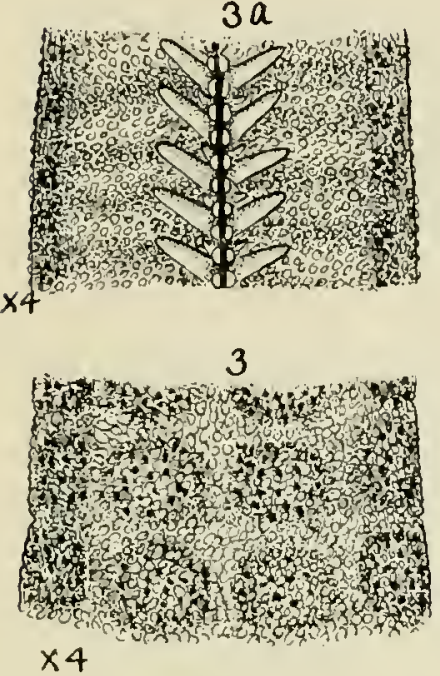
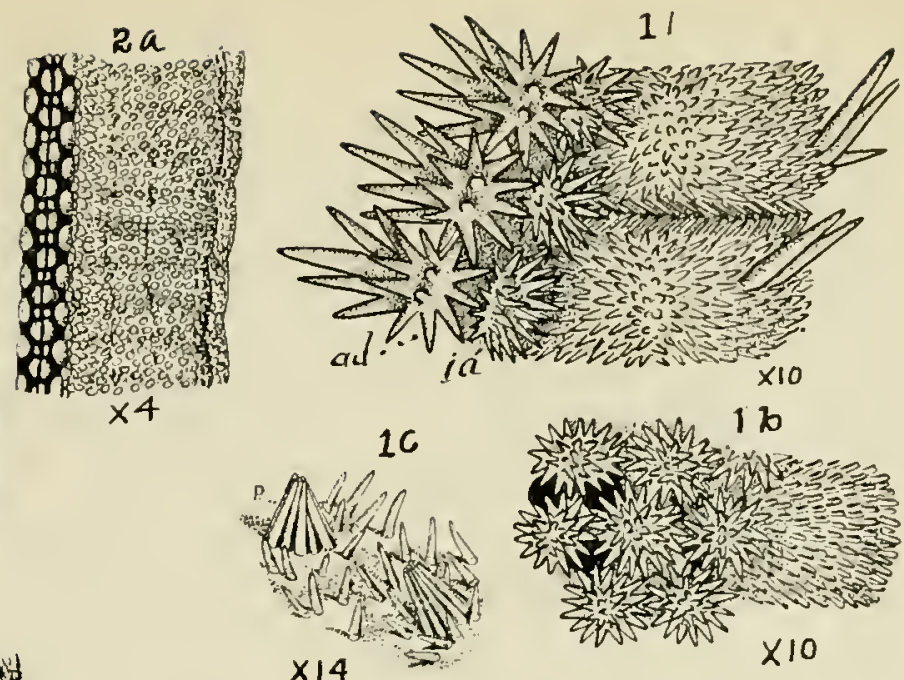

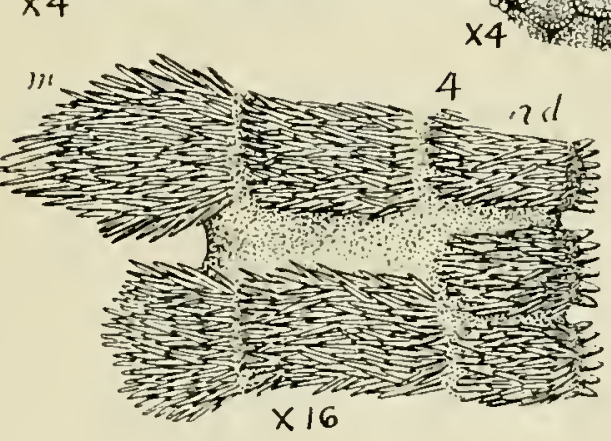

$4 a$

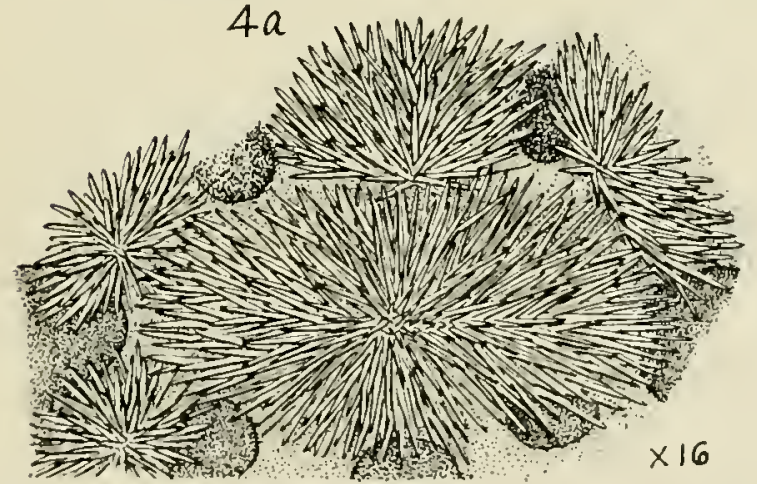

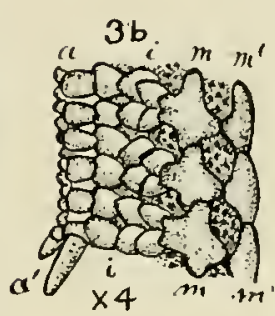
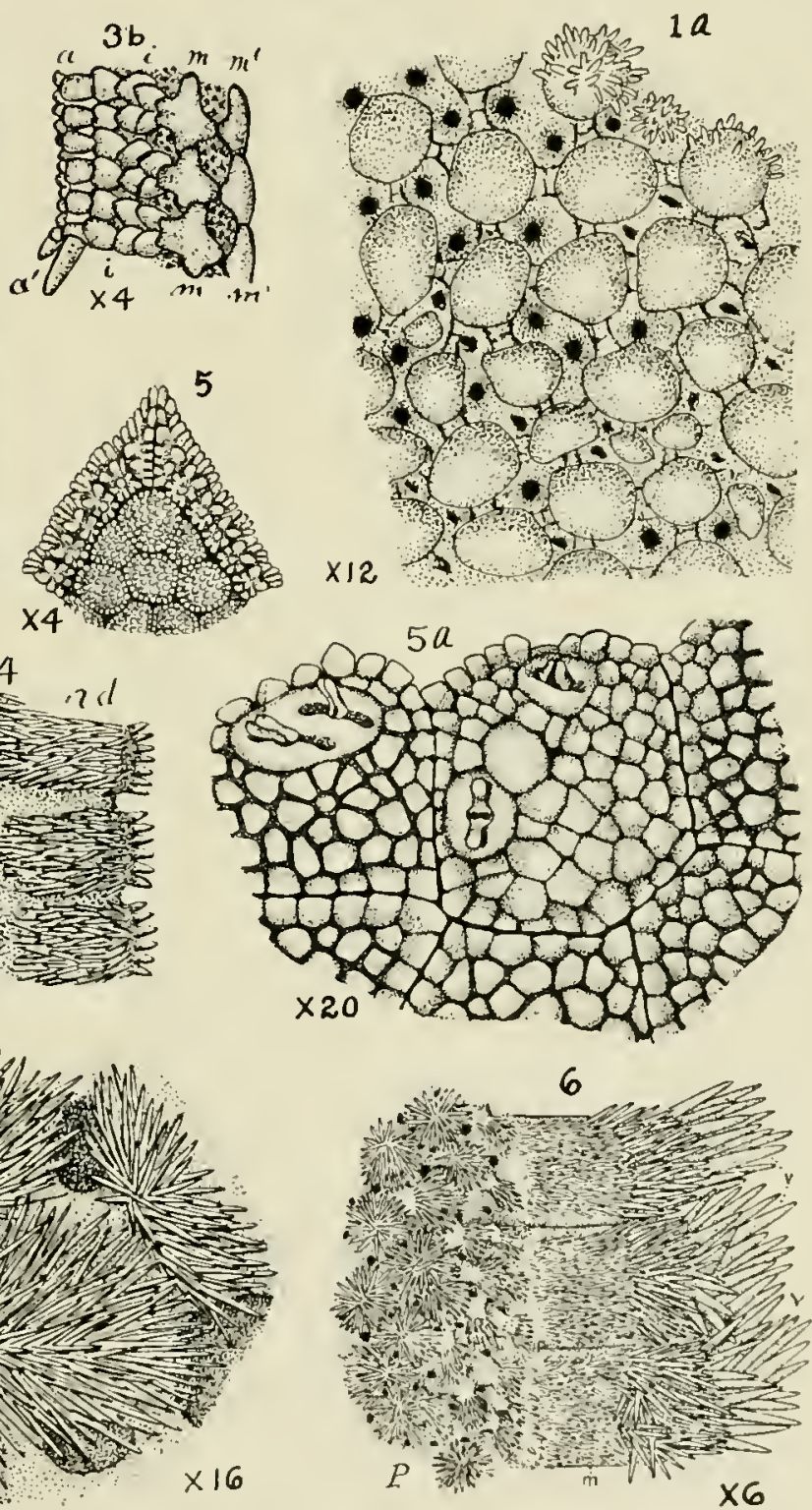

A. II. Verrill del.

WEST INDIAN S'TARFISIIES 



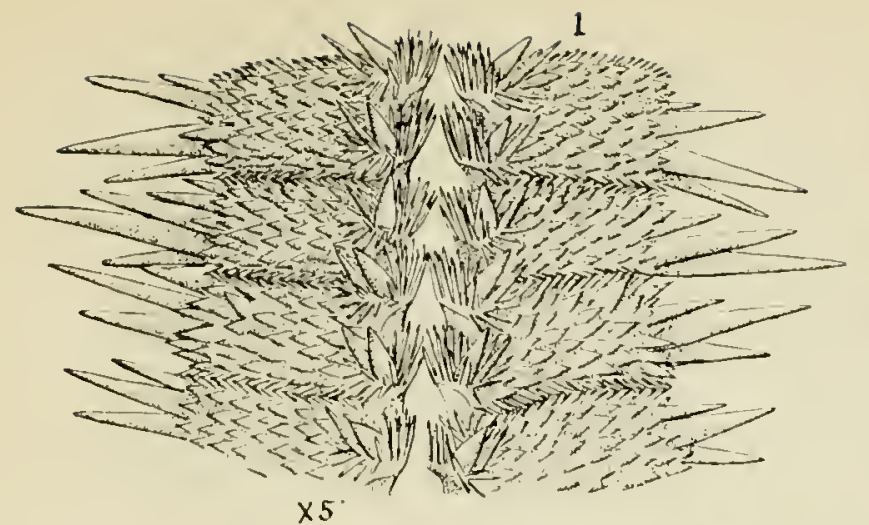

$\times 5$
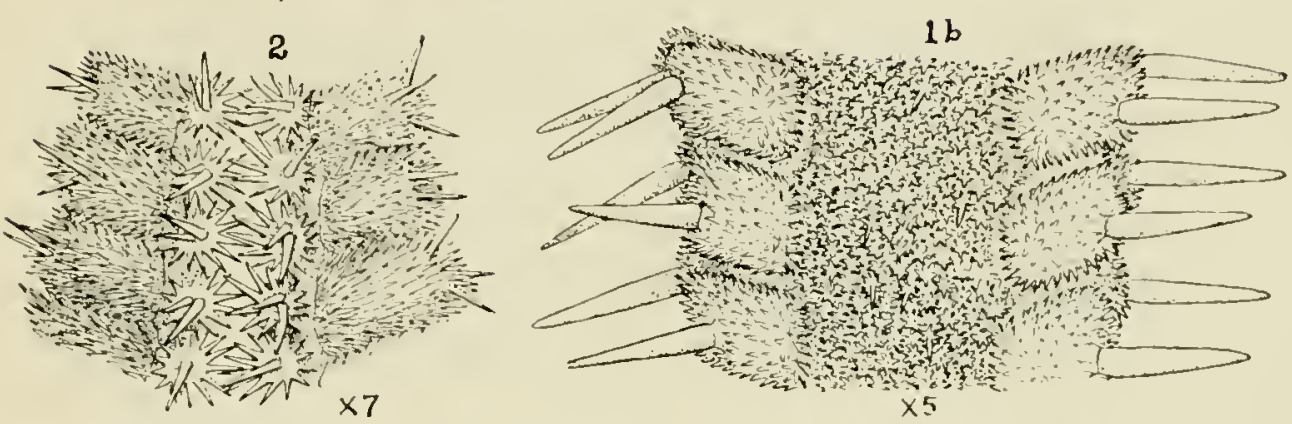

$5 a$

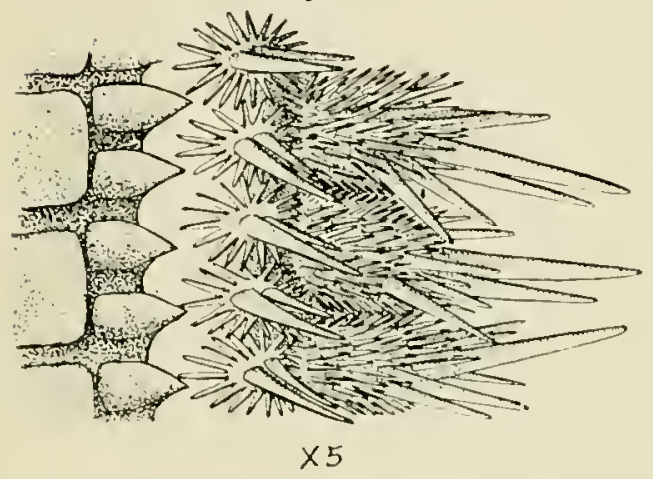

5

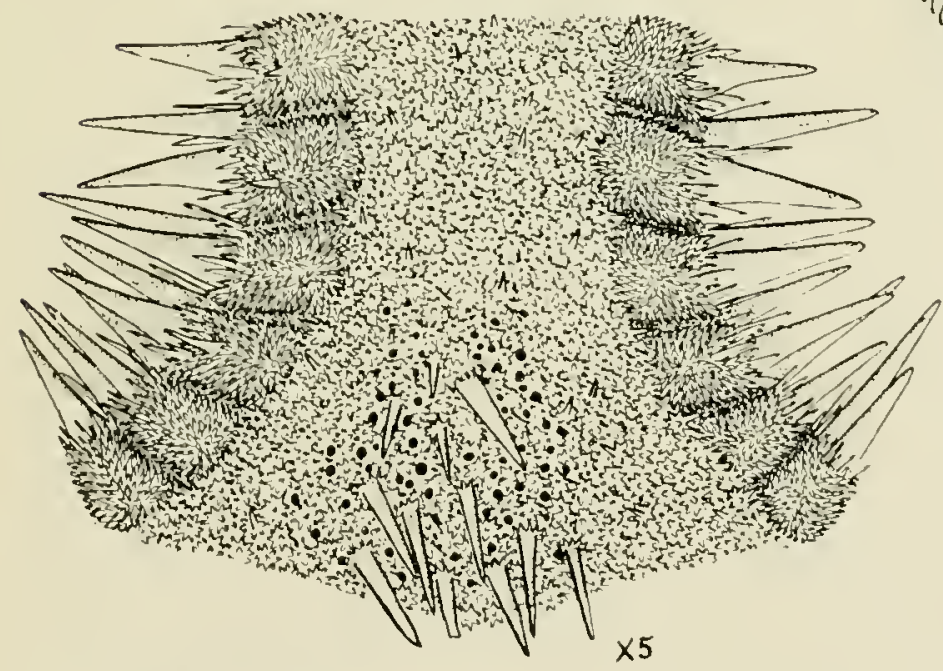

A. H. Terrill del.
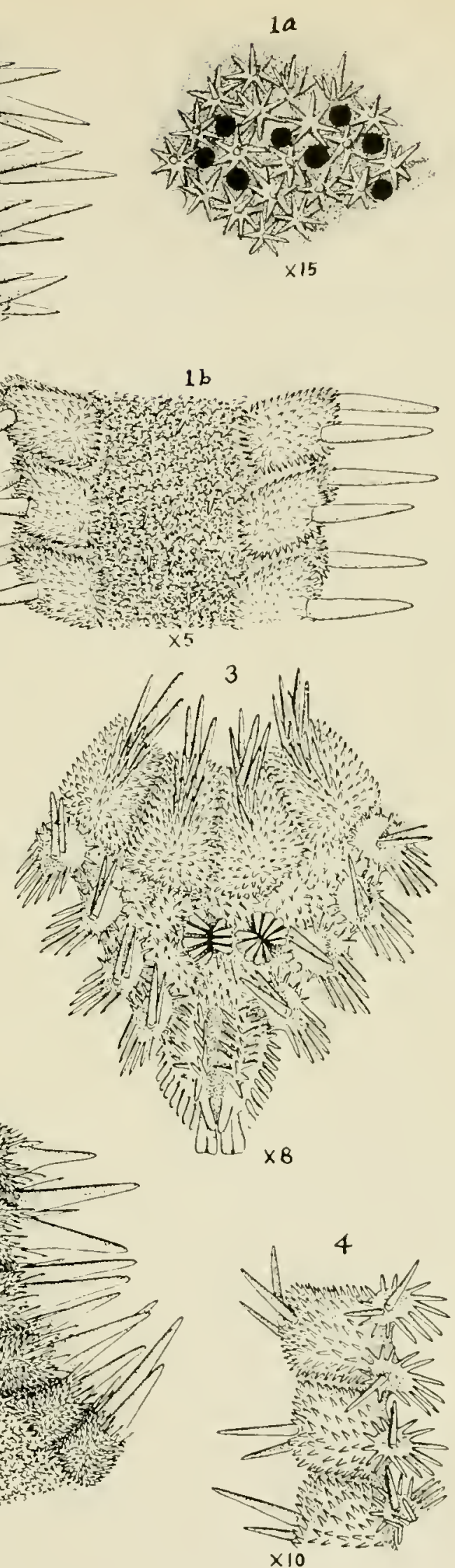

WEST INDIAN STARFISHES 



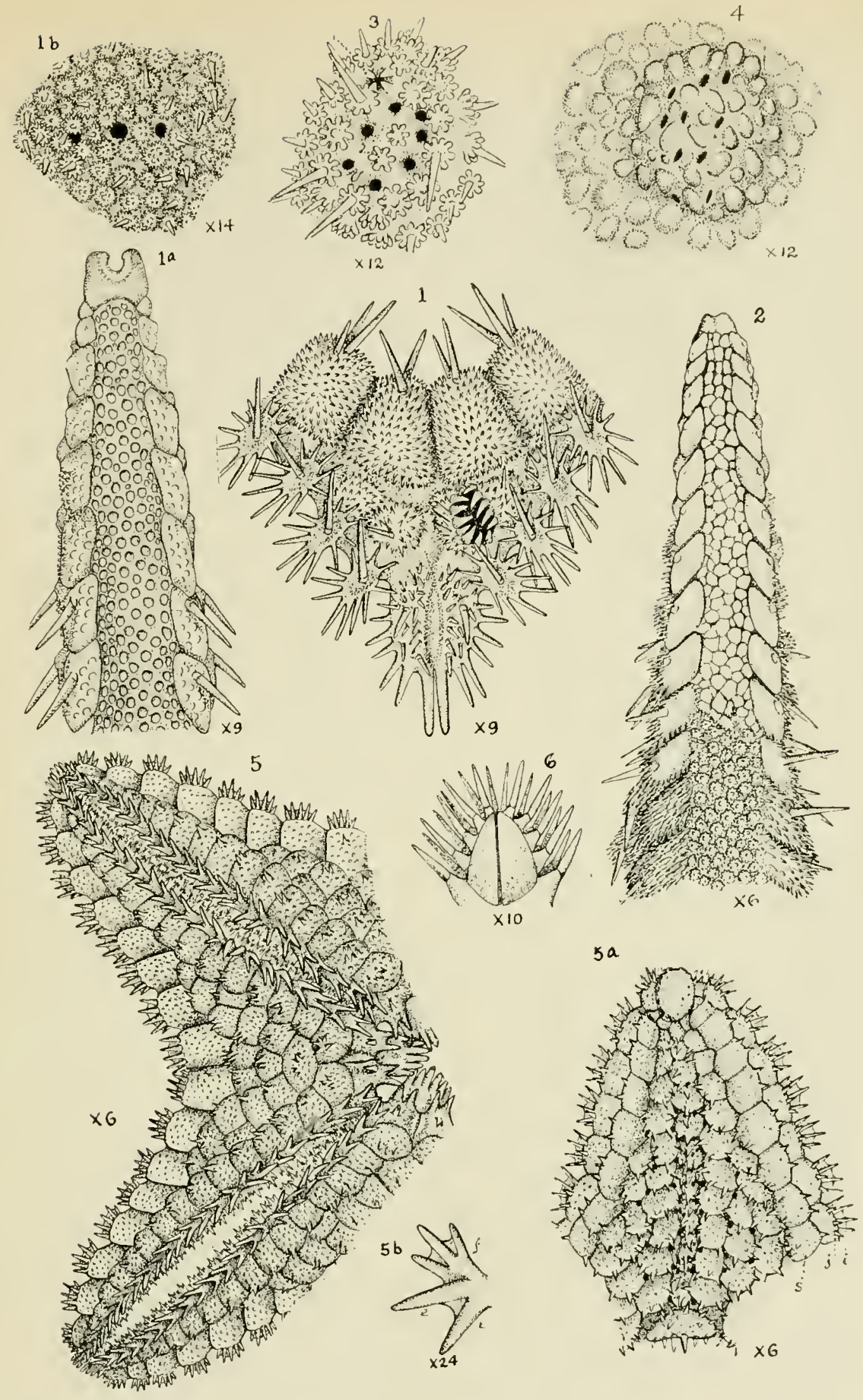

A. H. Terrill del.

WEST INDIAN S'TARFISHES 


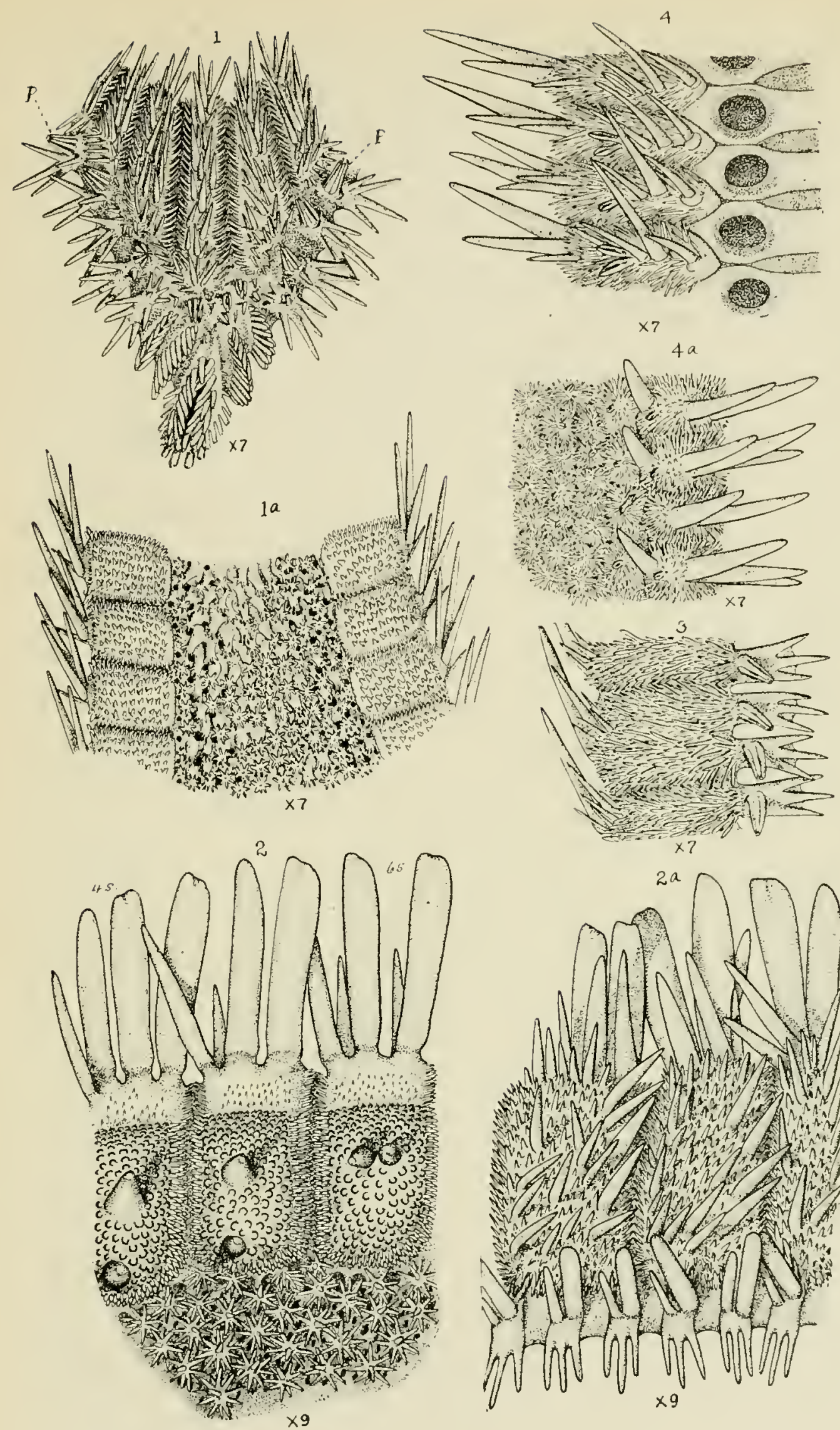

d. II. Terrill del.

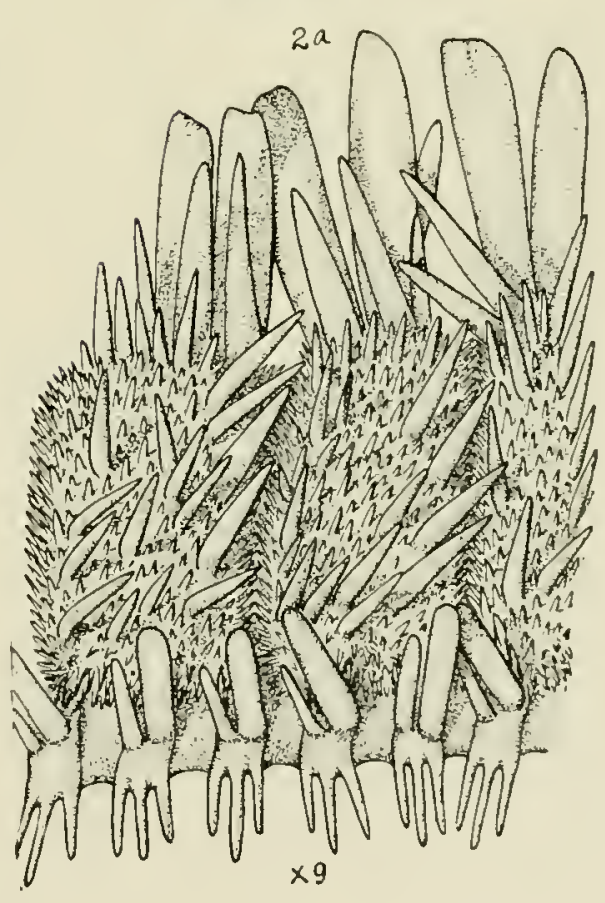

WEST INDIAN S'TARFISHES 



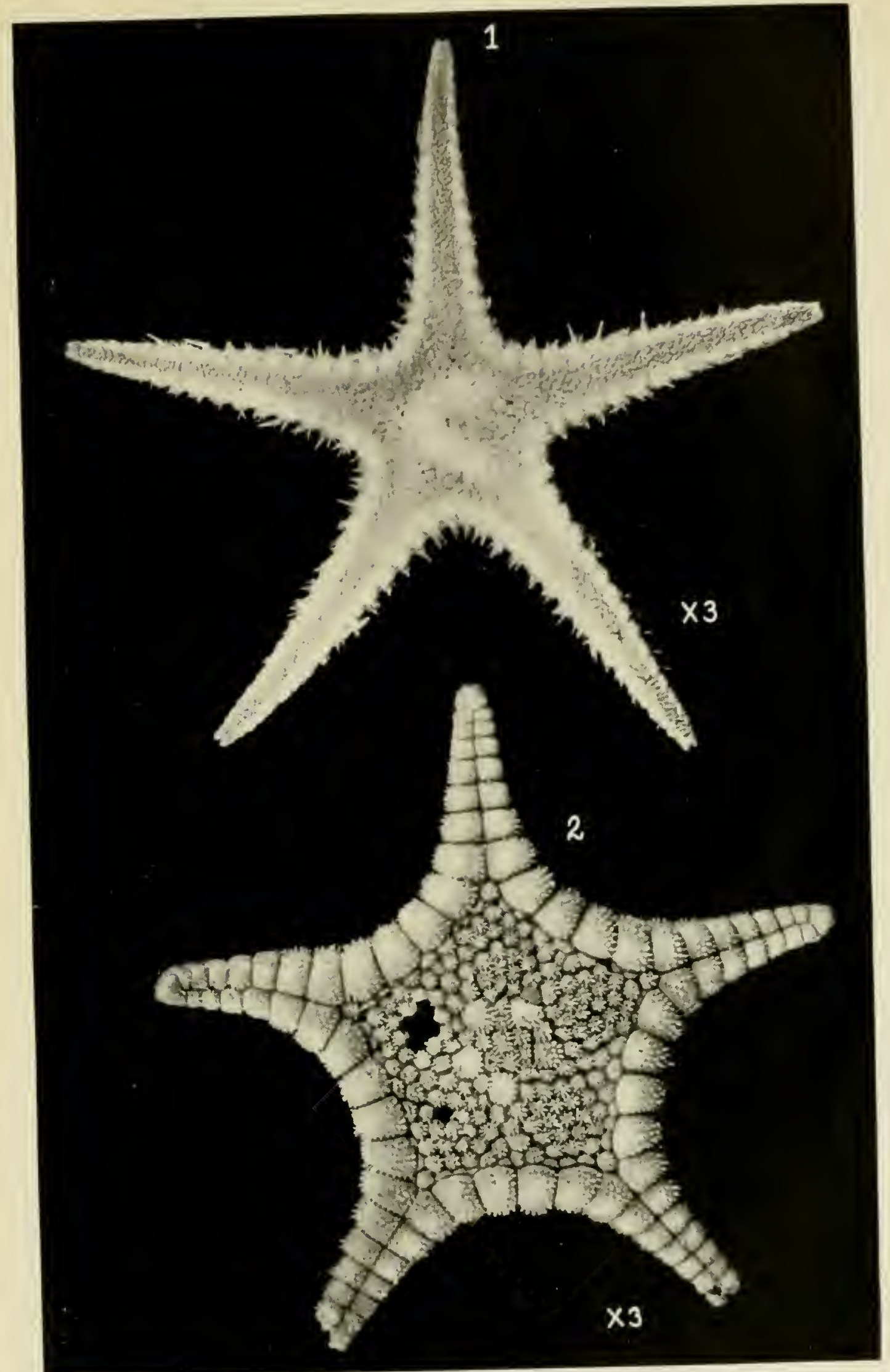

A. II. Terrill phot.

WEST INDIAN S'TARFISHES 

PLATE XVIII

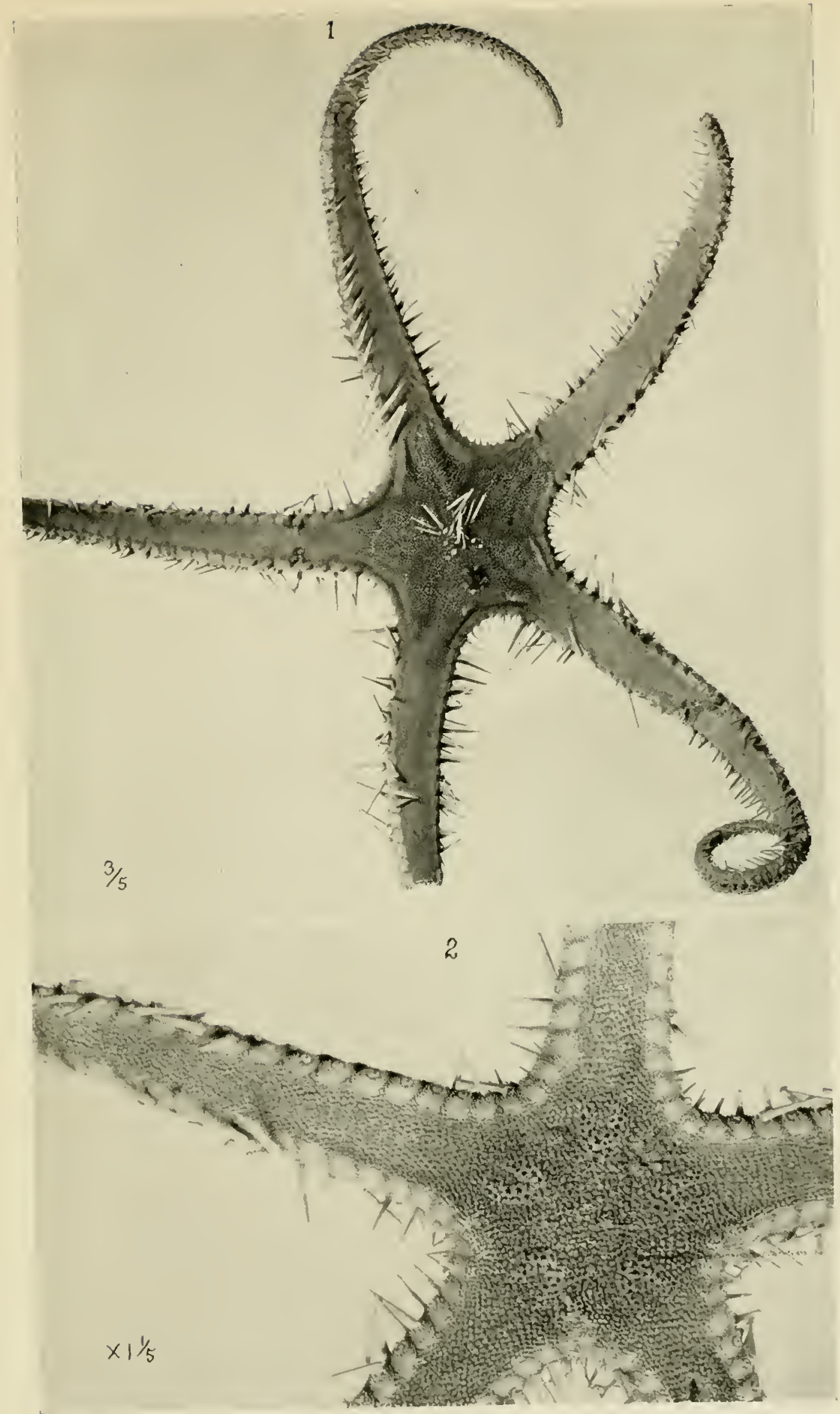

A. II. Verrill phot.

WEST INDIAN STARFISHES 



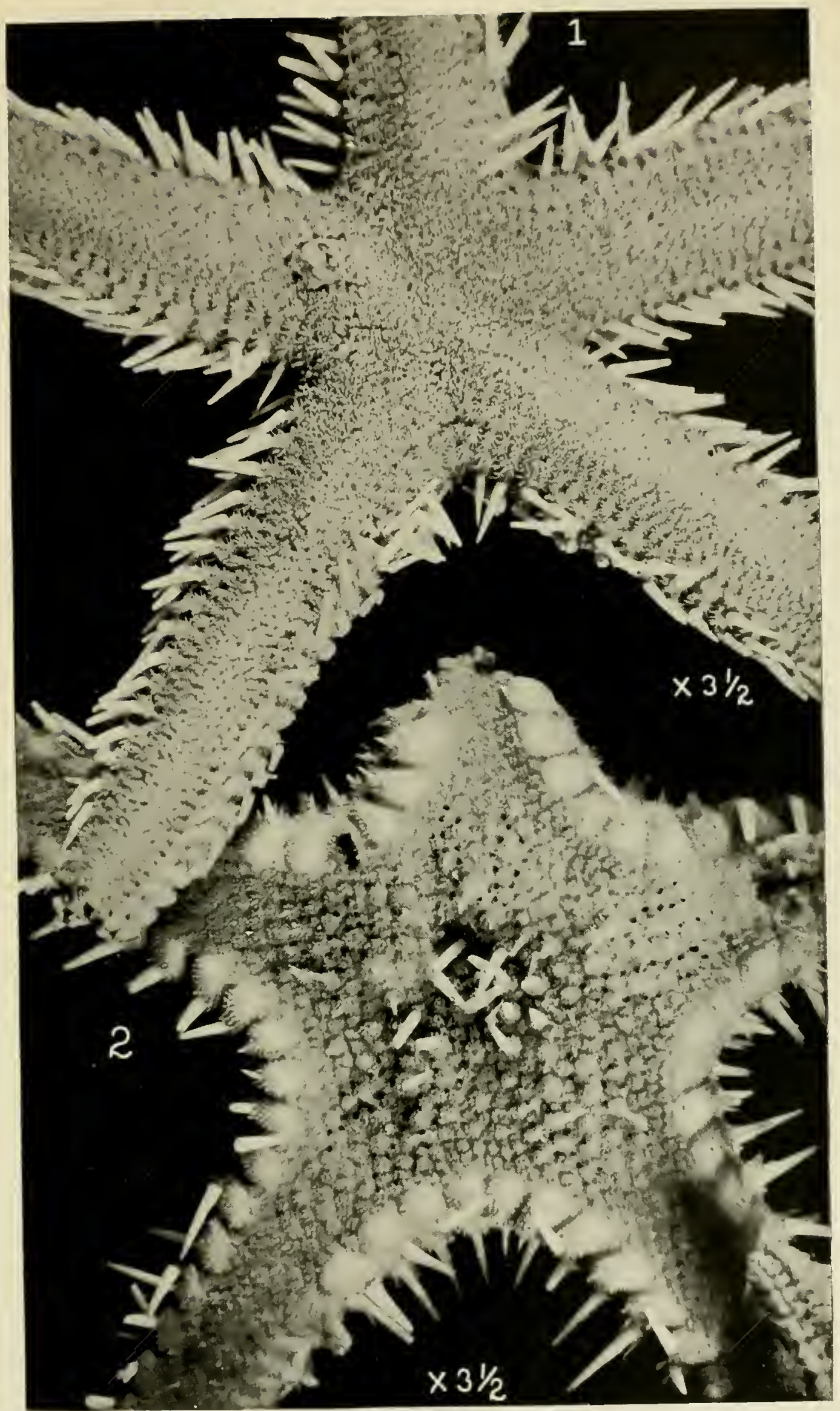

A. II. Terrill phot

WEST INDIAN STARFISIIES 



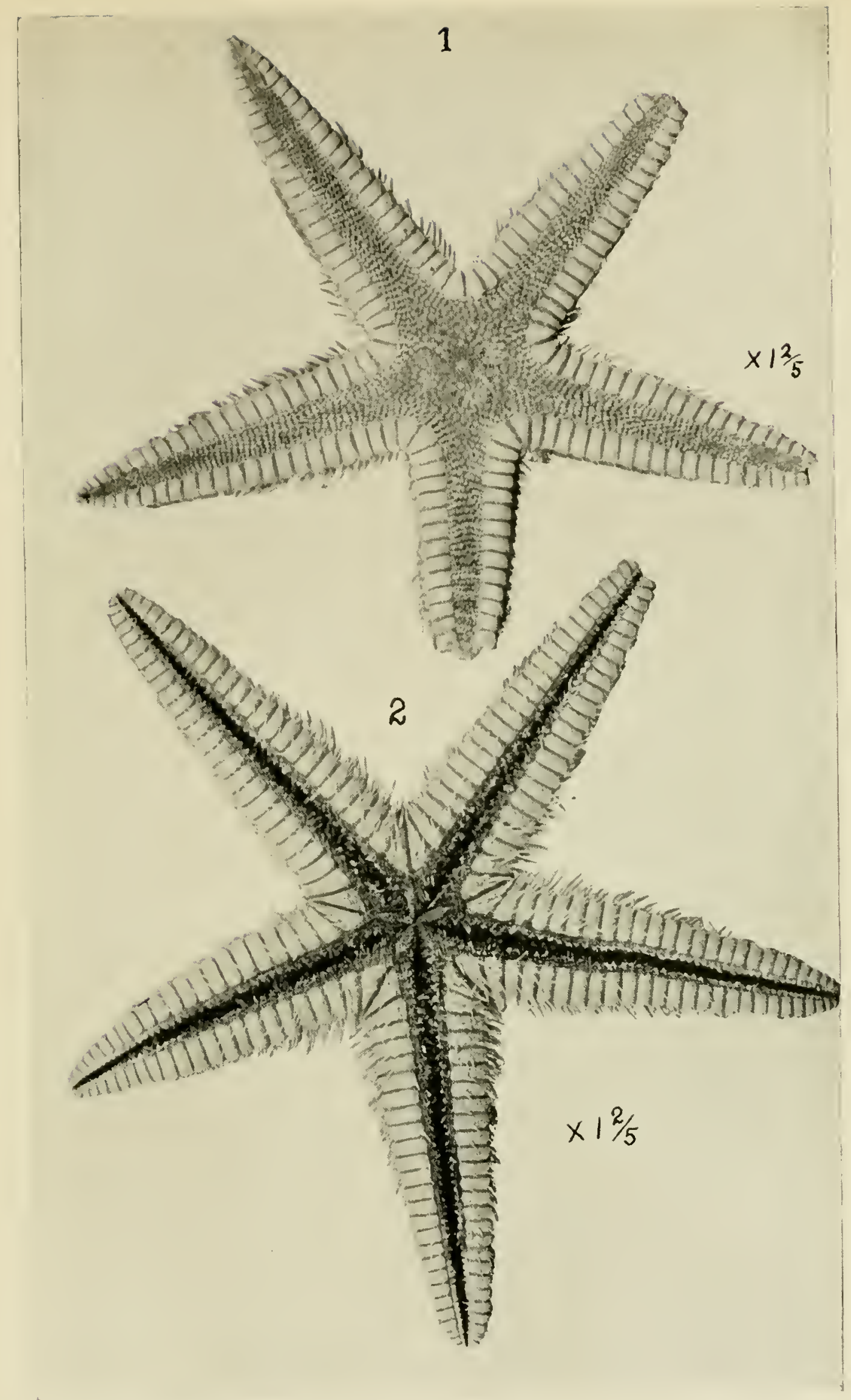

A. H. Verrill phot.

WES'T INDIAN STARFISHES 



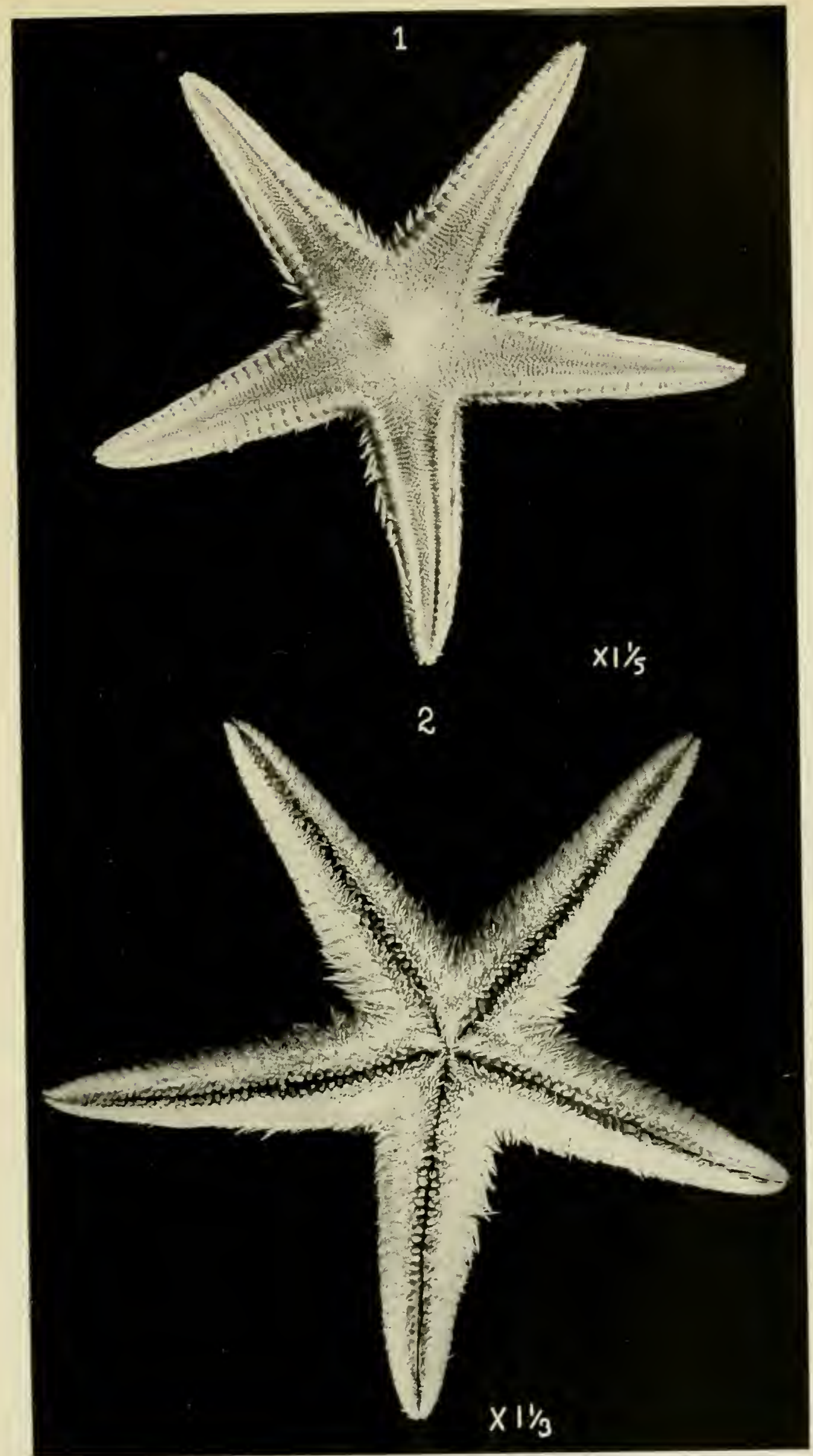

A. H. Terrill phot 



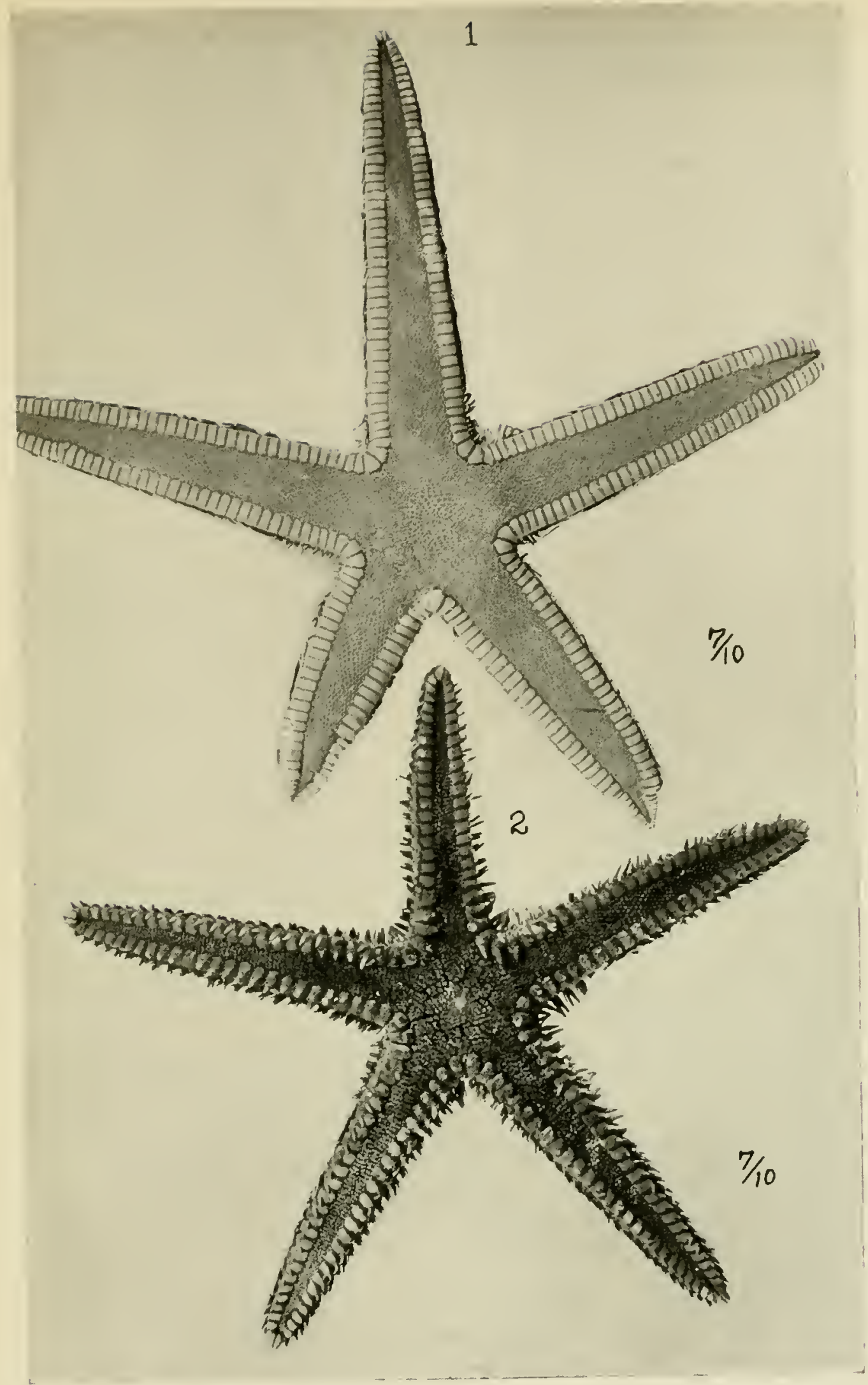

A. H. Ferrill phot.

WEST INDIAN STARFISHES 



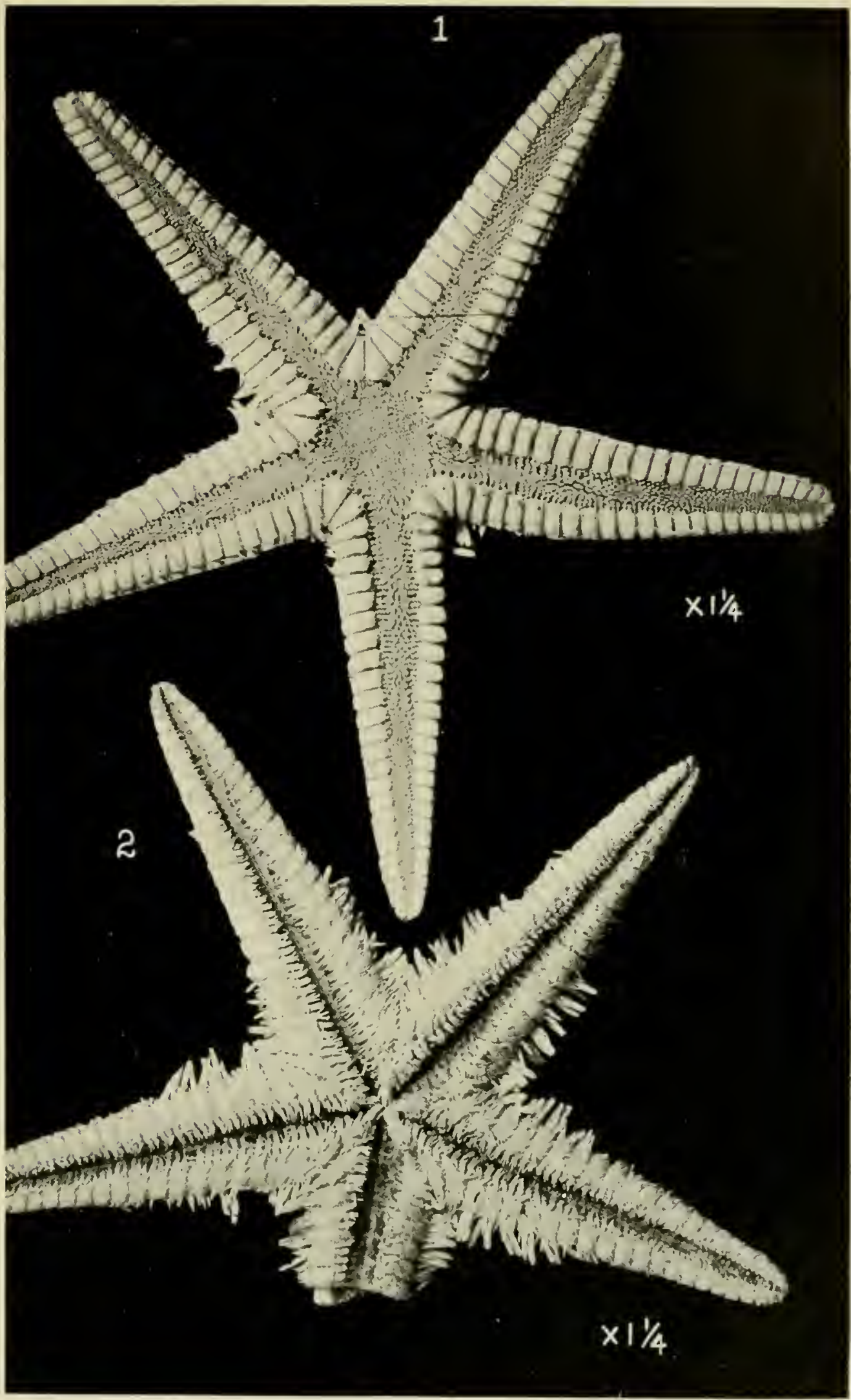

A. H. Terrill phot.

WEST INDIAN STARFISHES 

PLATE XXIV
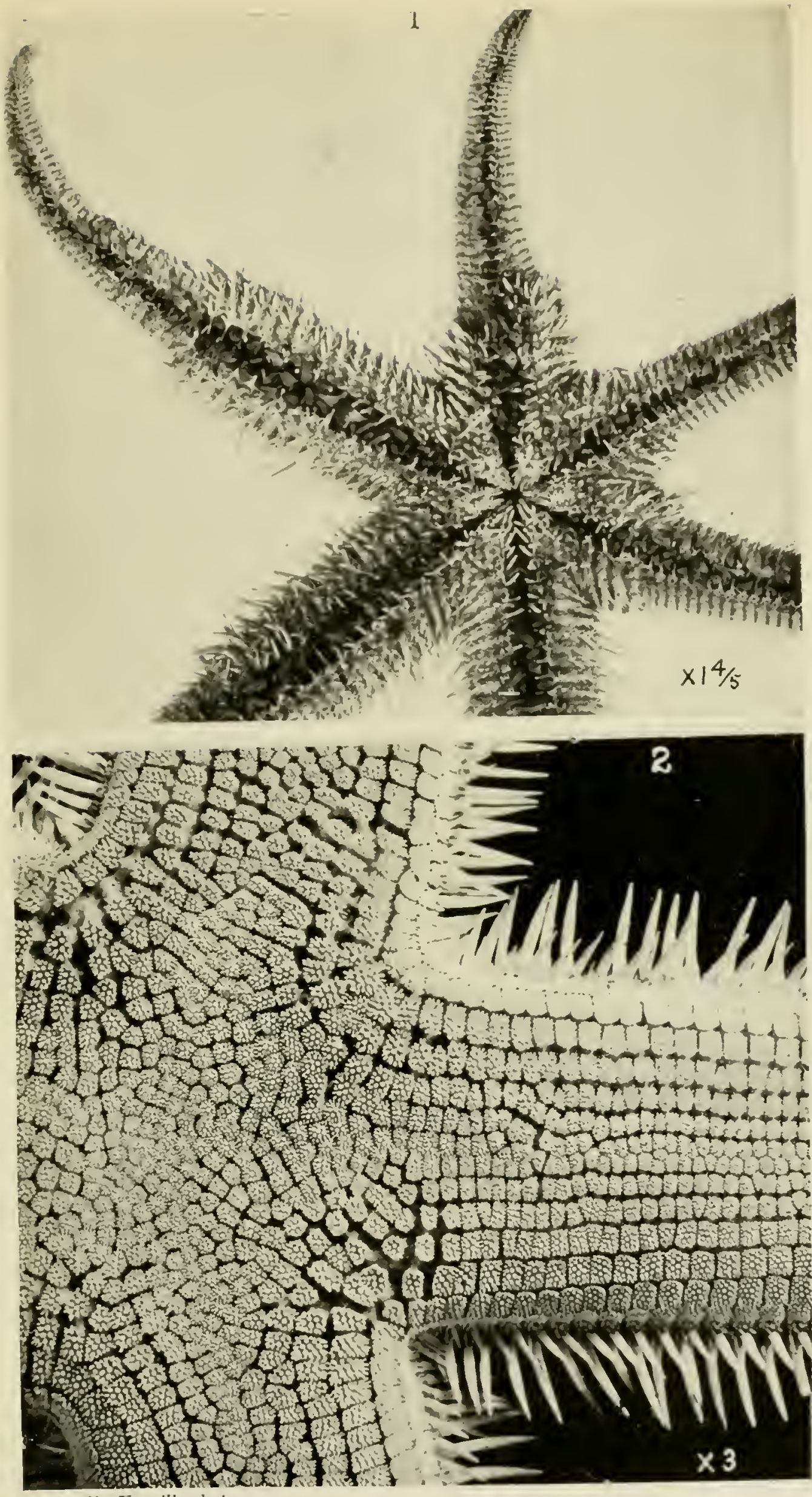

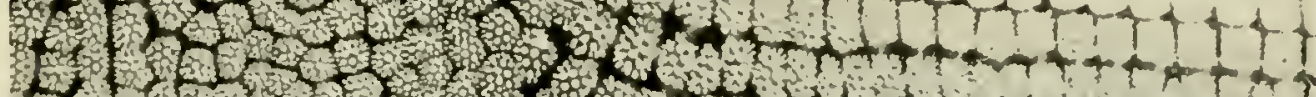

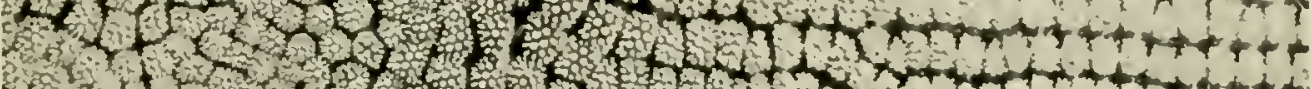

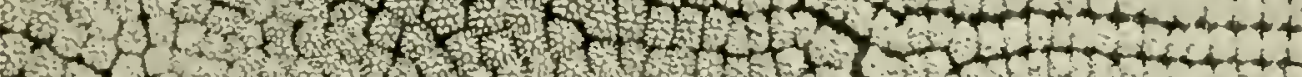
4 .

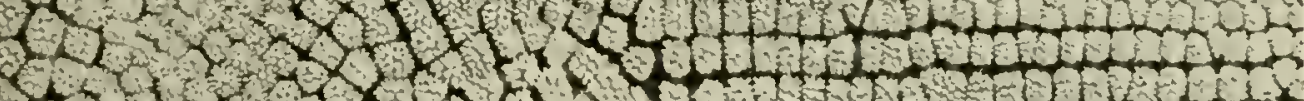

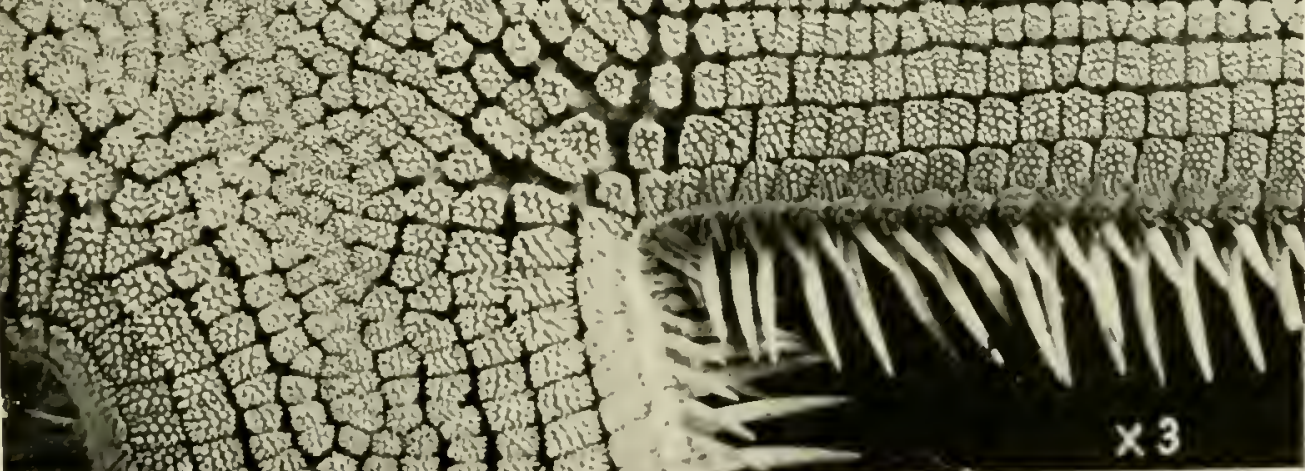
A. II. Terrill pheto. 



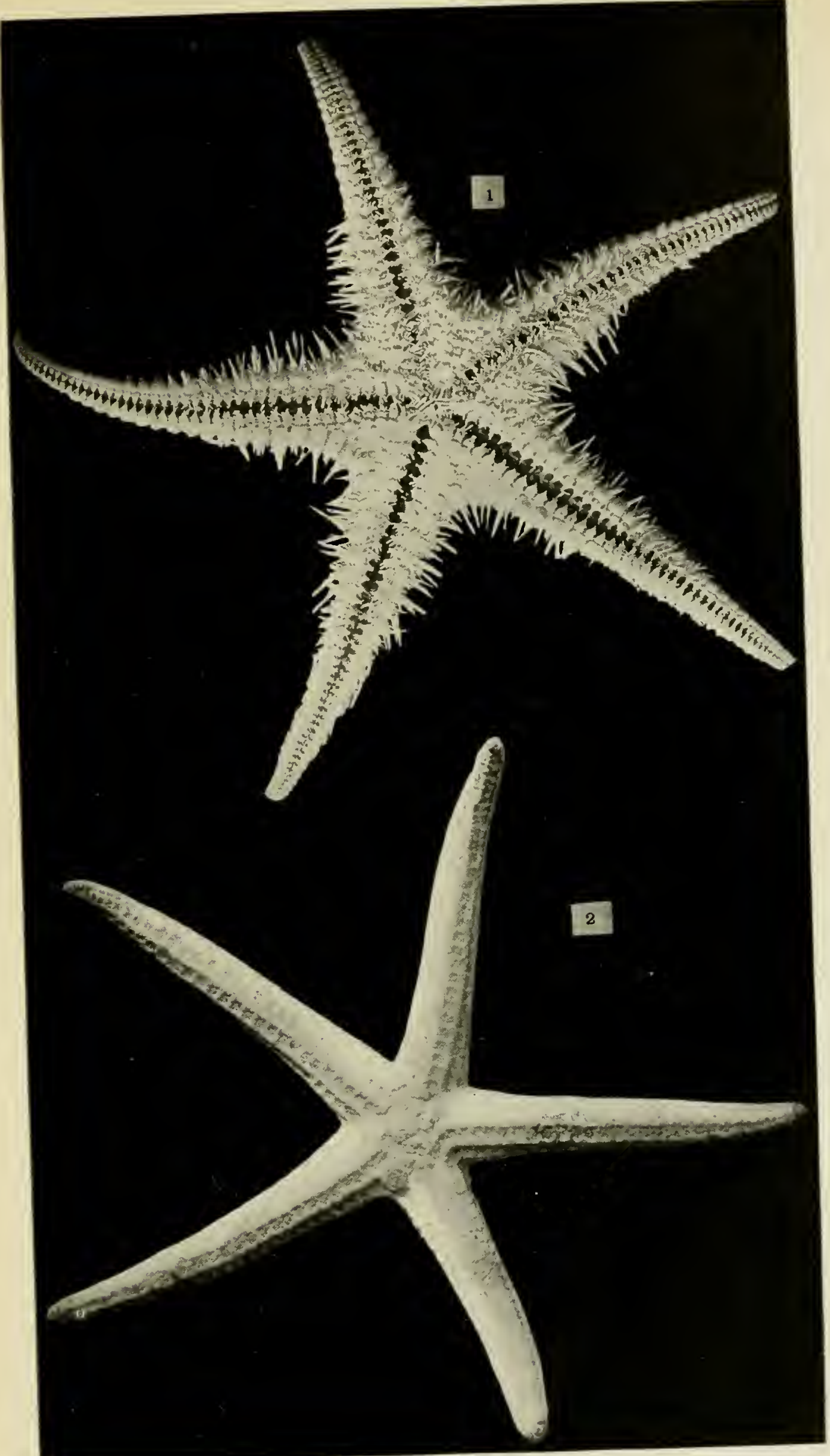

A. H. Terrill phot.

WEST INDIAN STARFISHES 


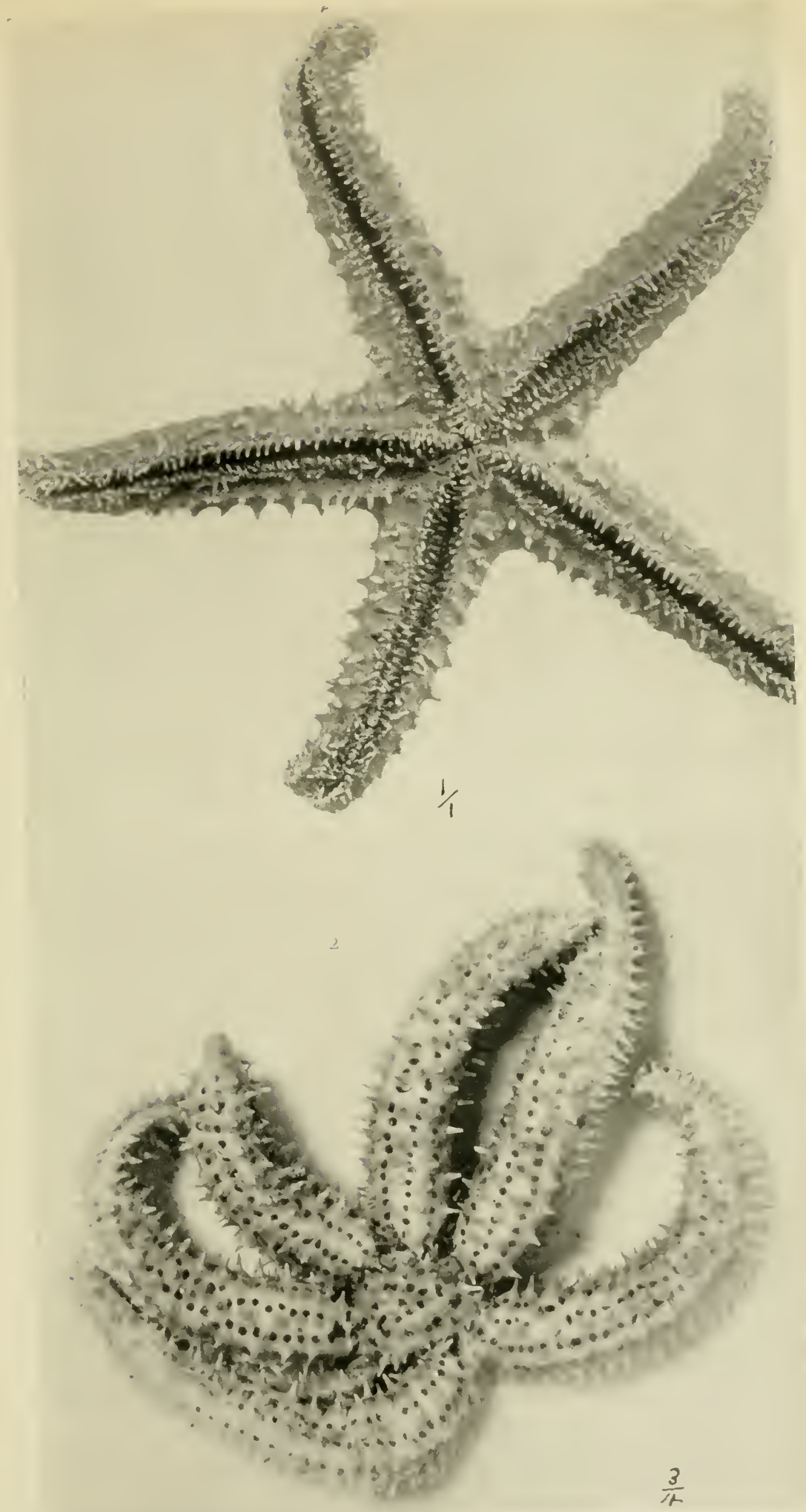

A. U. Terrill phot. 



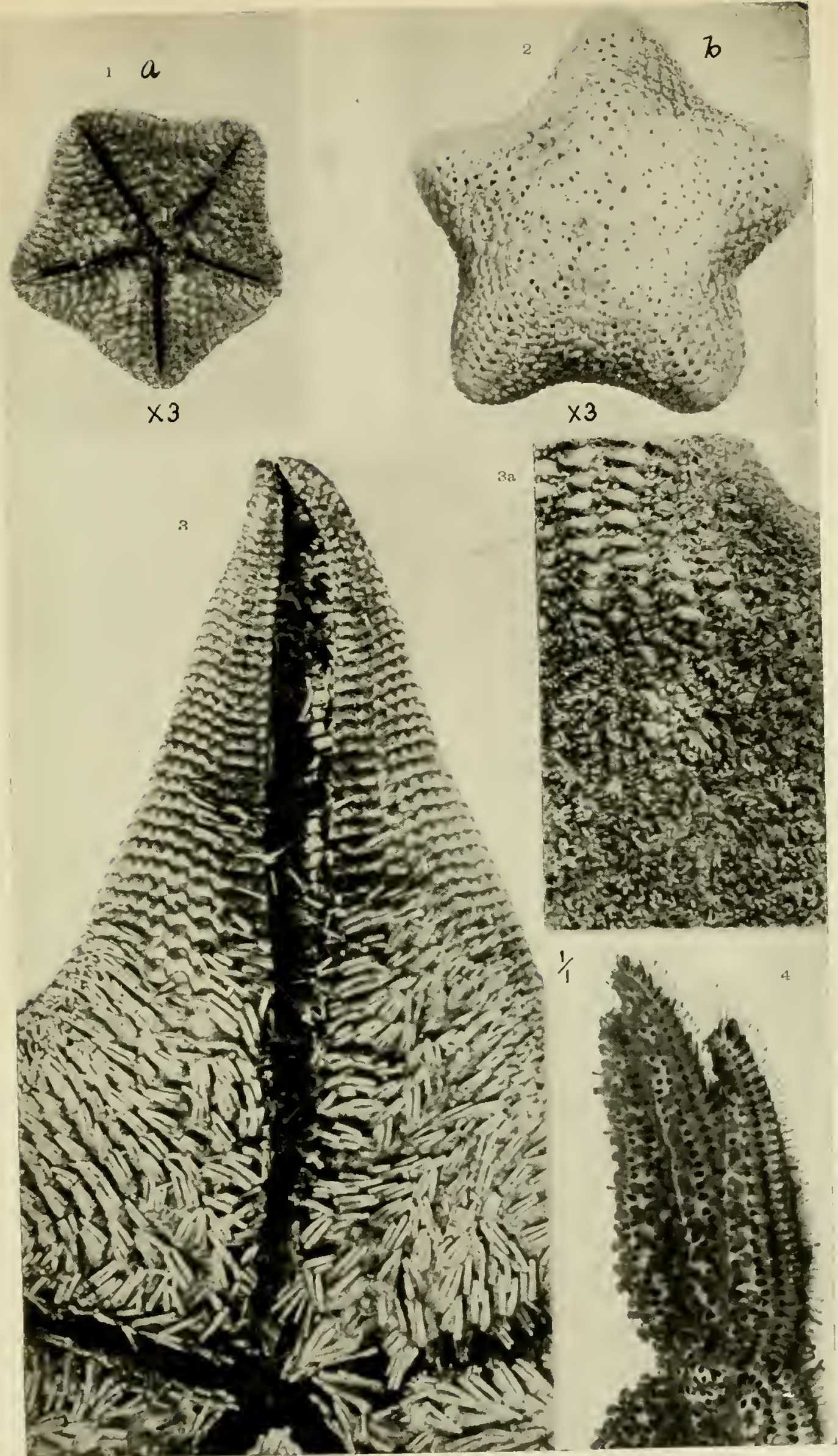

A. II. Terrill phot.

WEST INDIAN STARFISHES 



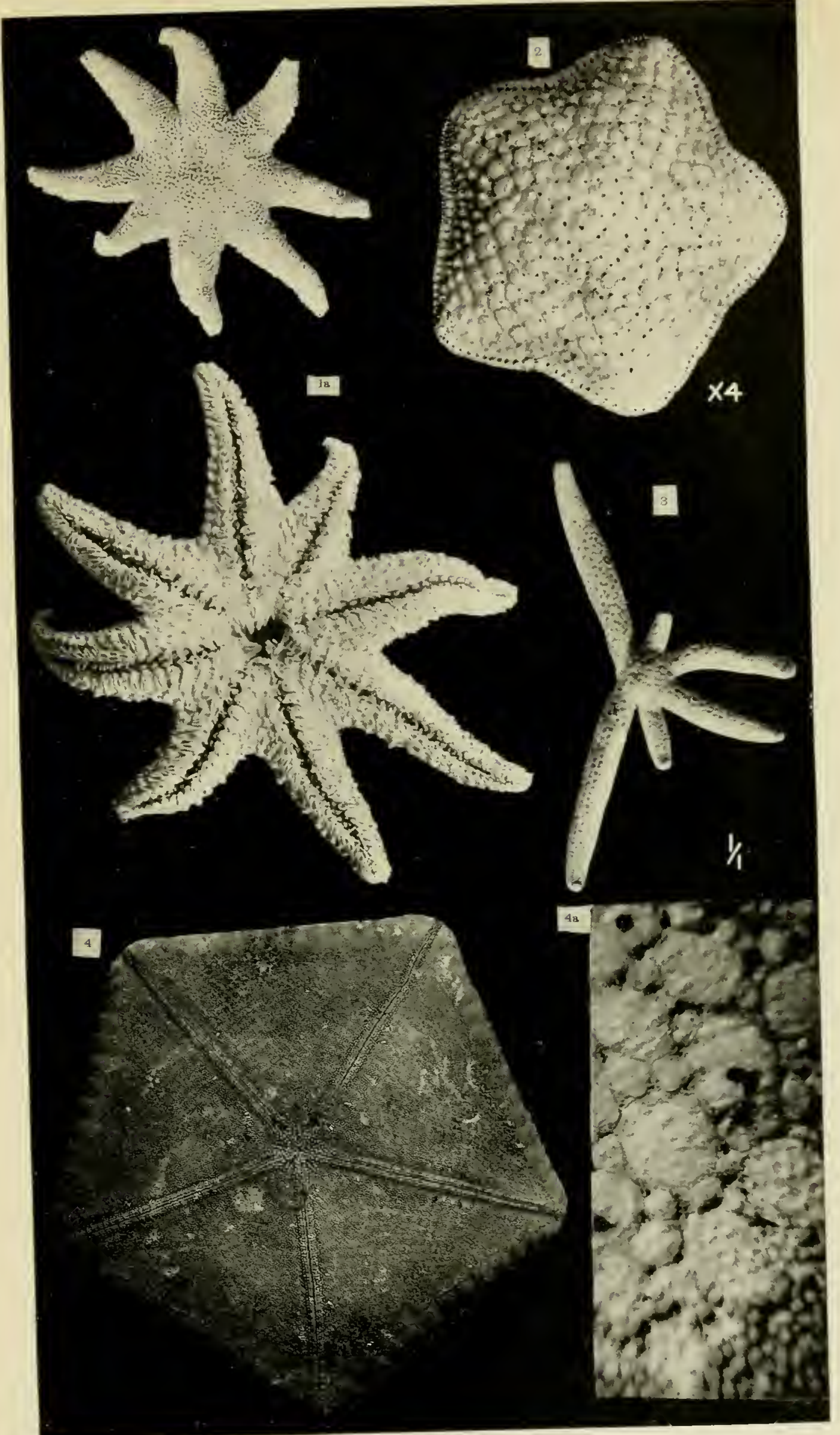

A. II. Verrill phot.

WEST INDIAN STARFISHES 



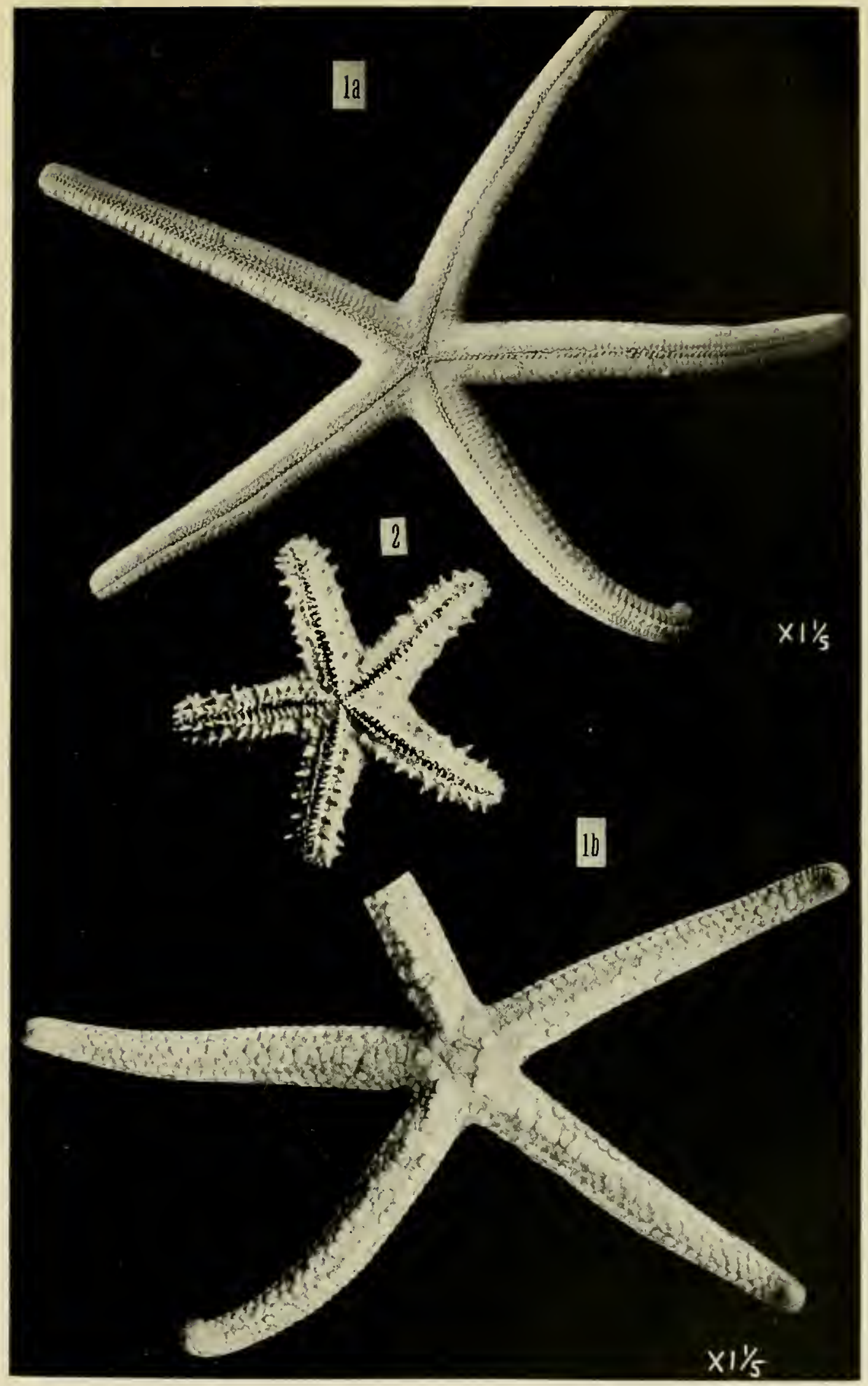

A. II. Verrill phot.

WEST INDIAN STARFISHES 




















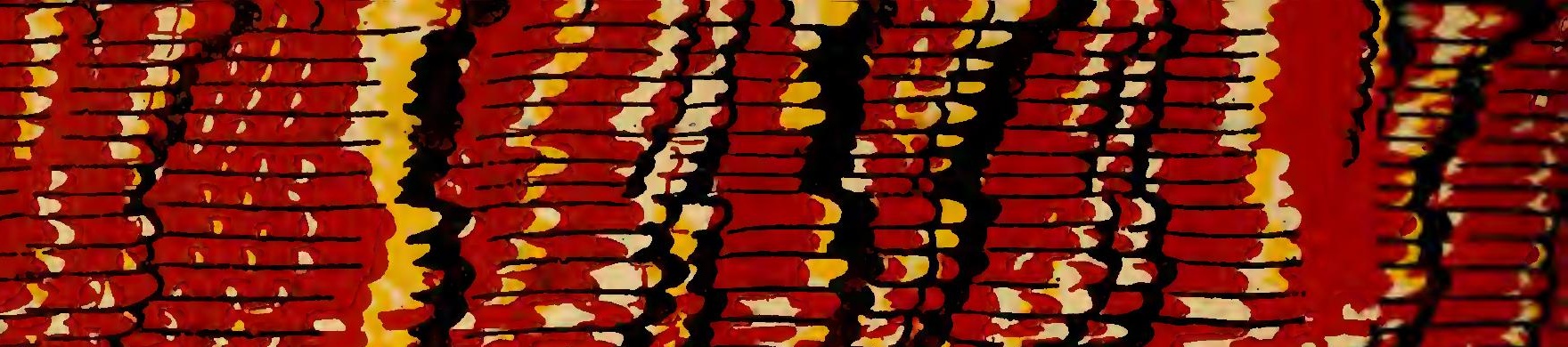

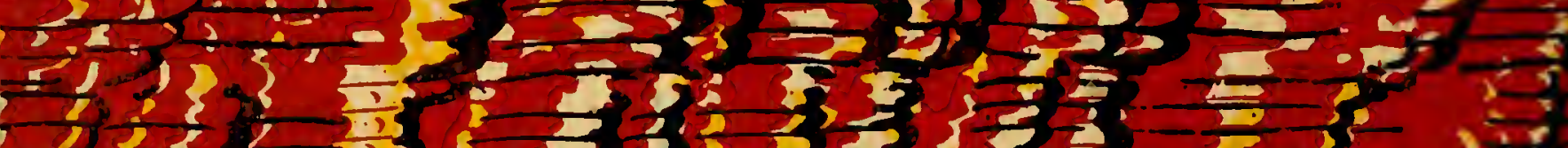

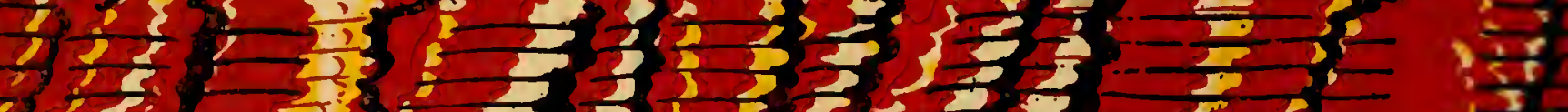

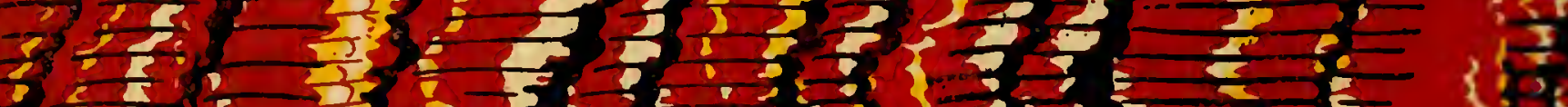

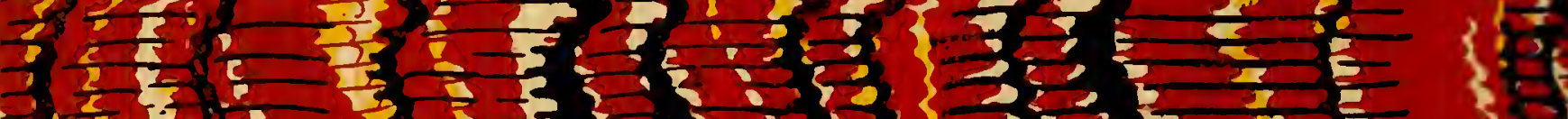

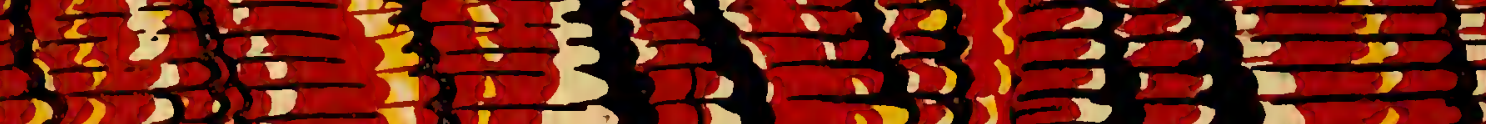

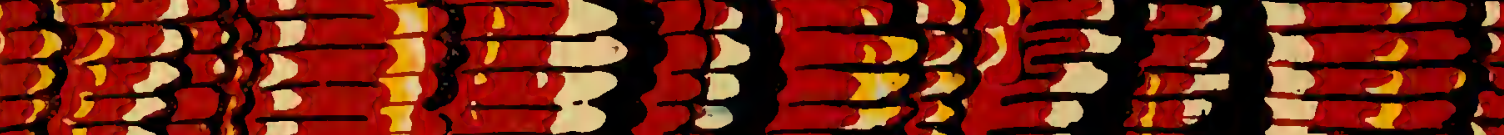

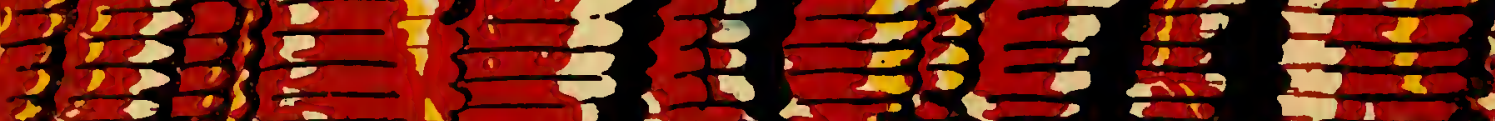

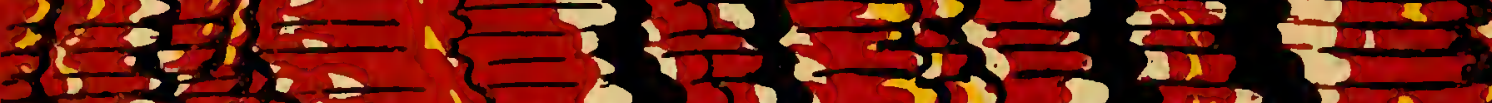

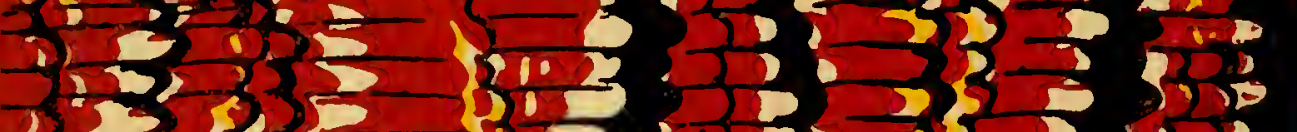

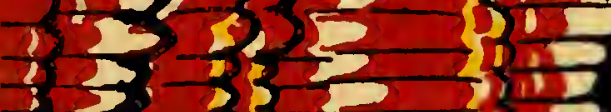

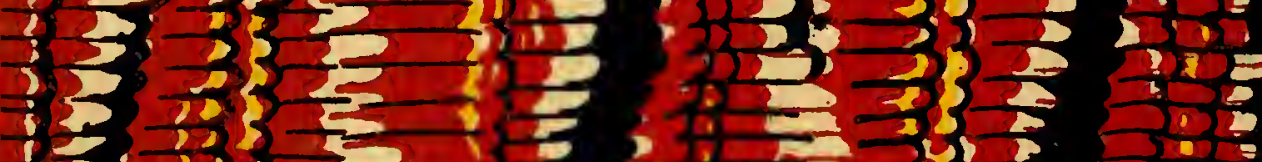

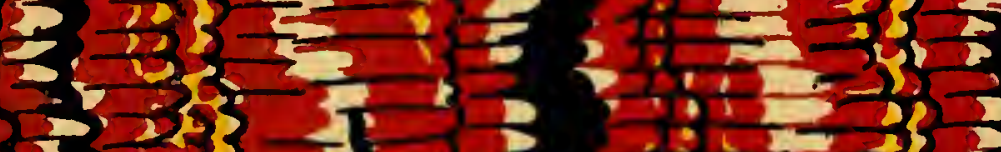

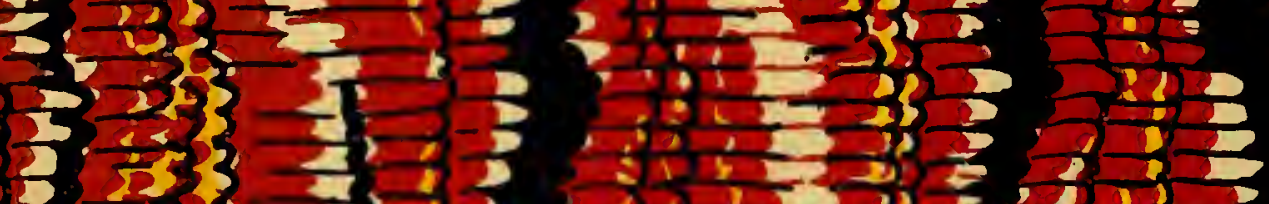

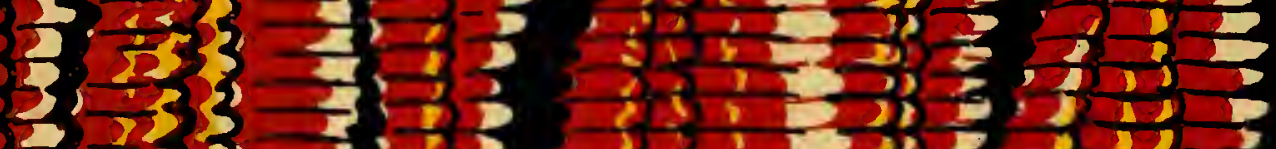

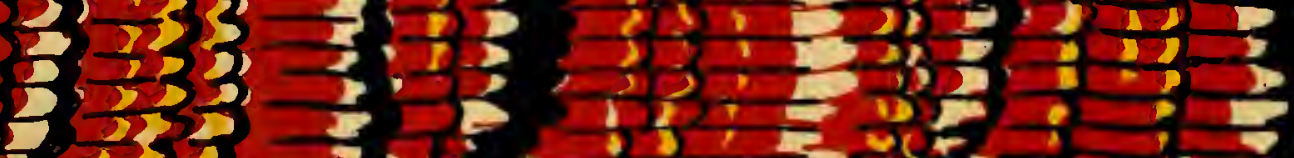

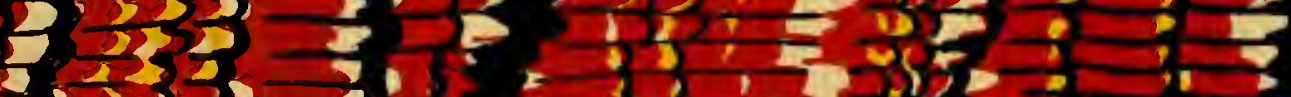

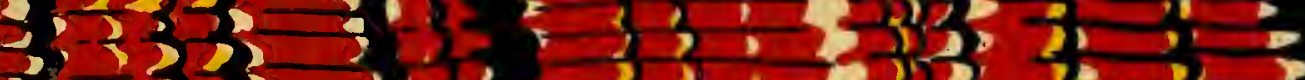

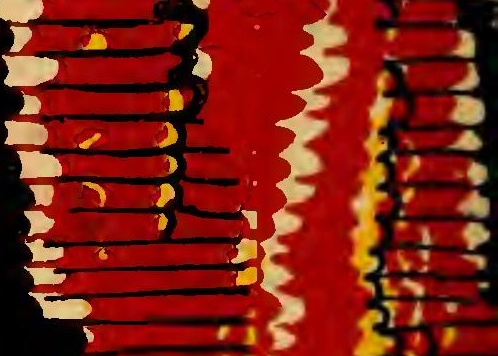

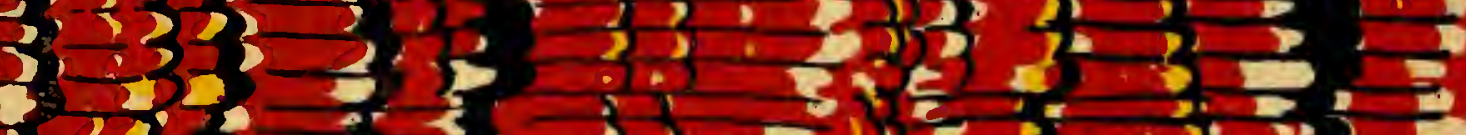

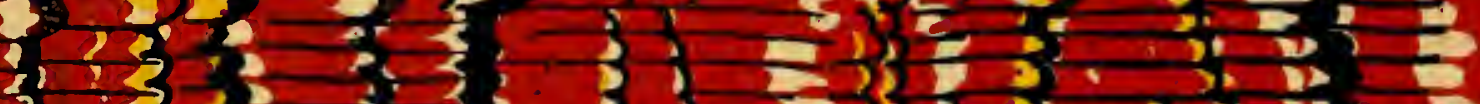

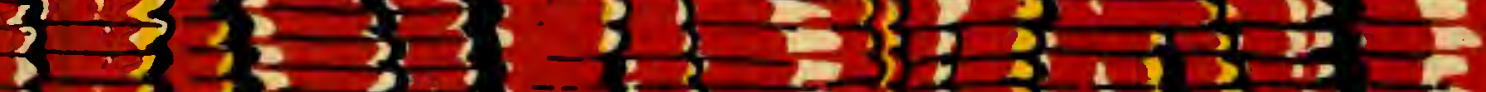

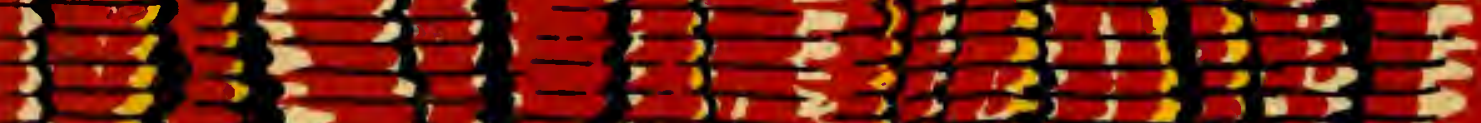

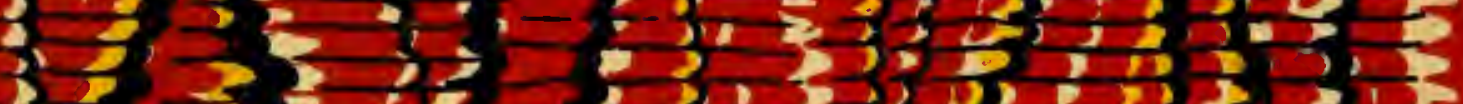

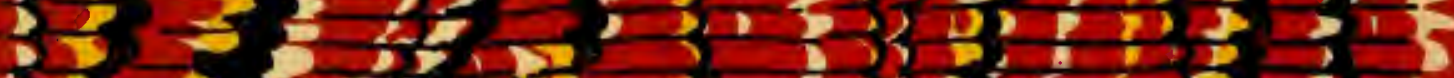

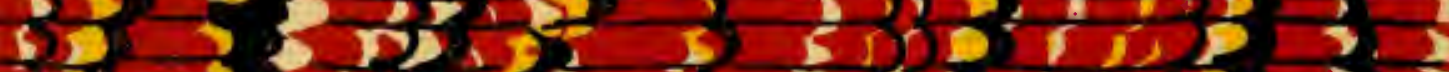

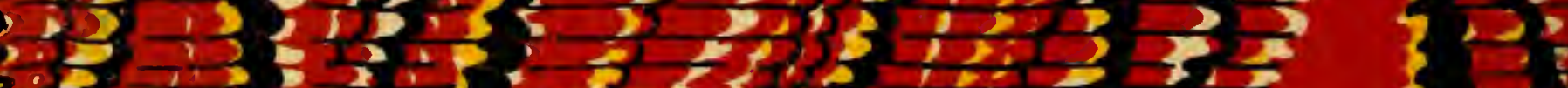

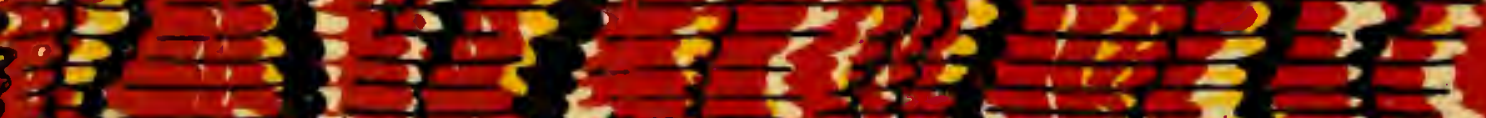

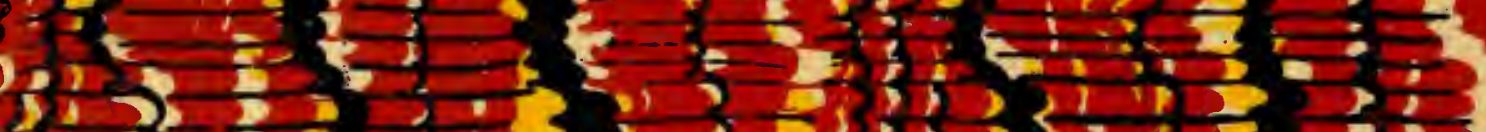

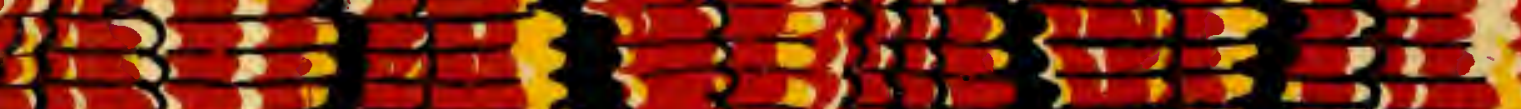

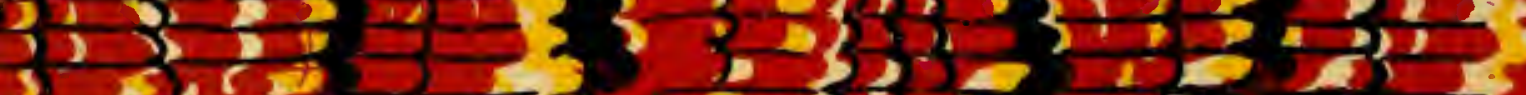

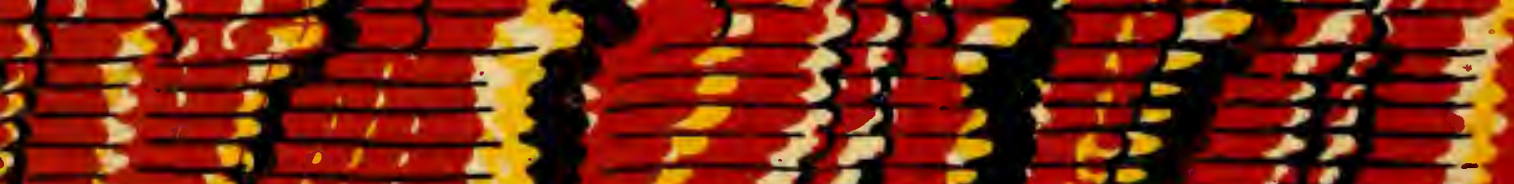

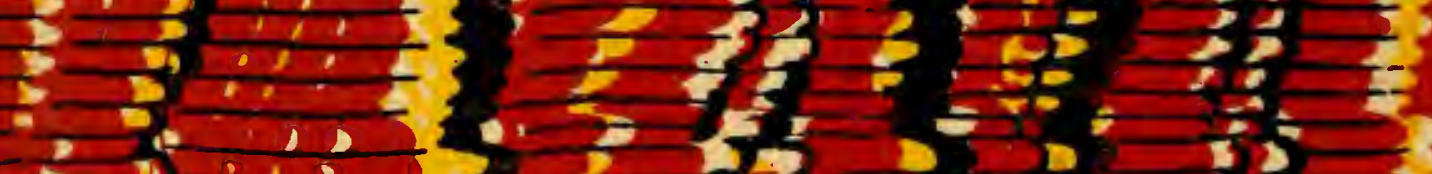

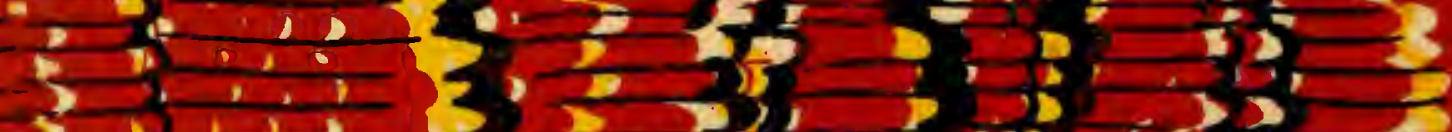

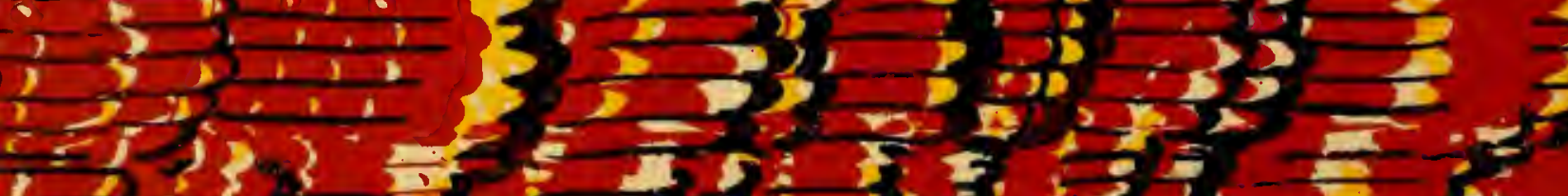

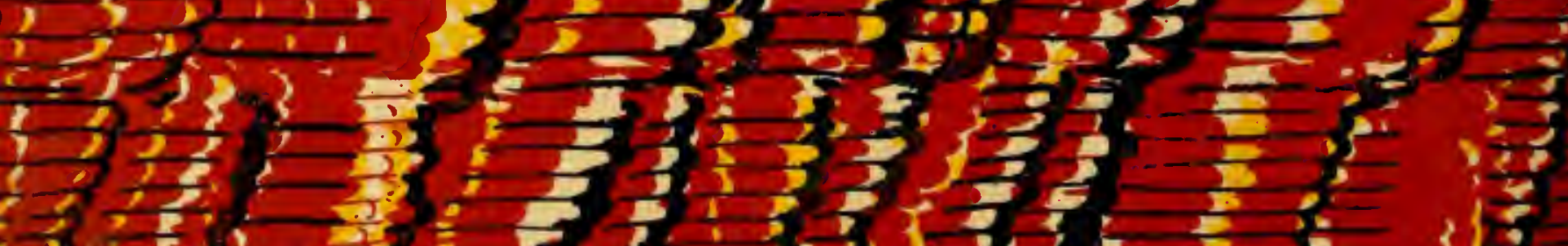
$=21 ?$

$3 \frac{1}{3}$

5<smiles>[Te][Te]</smiles>

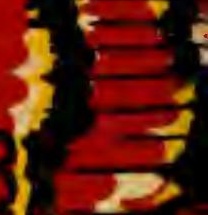




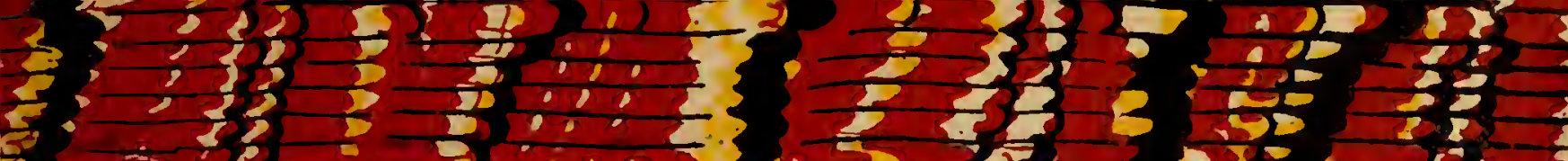

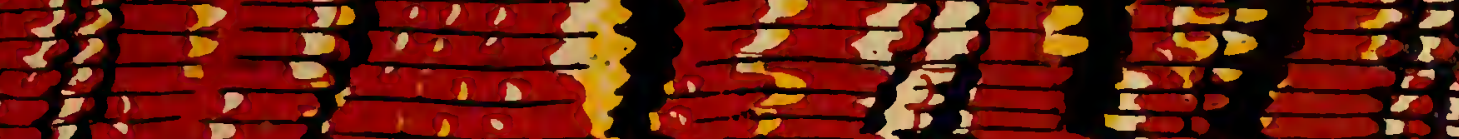

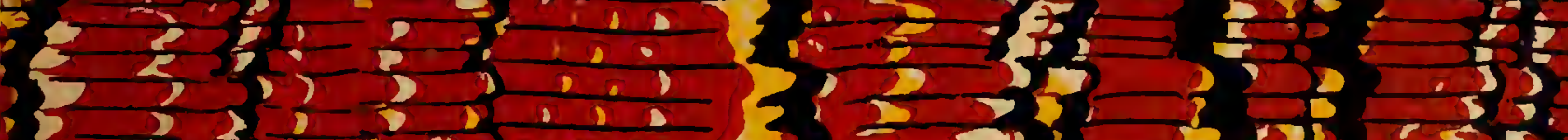

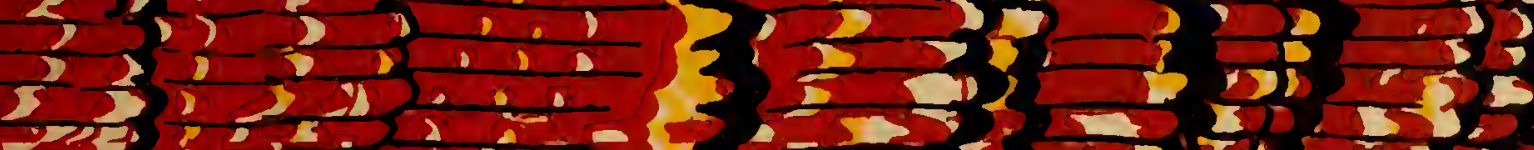

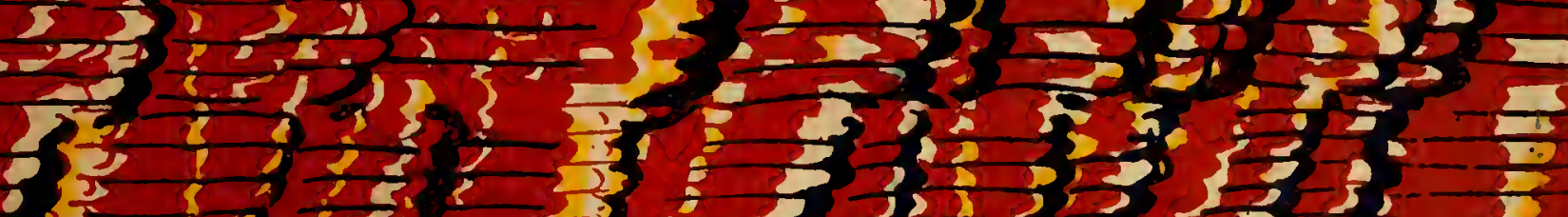

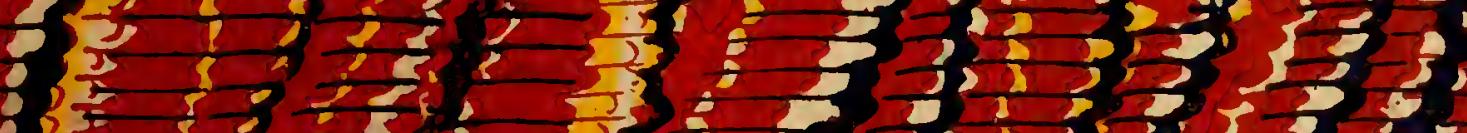

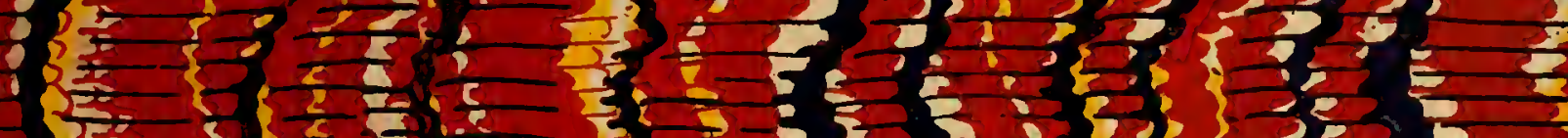

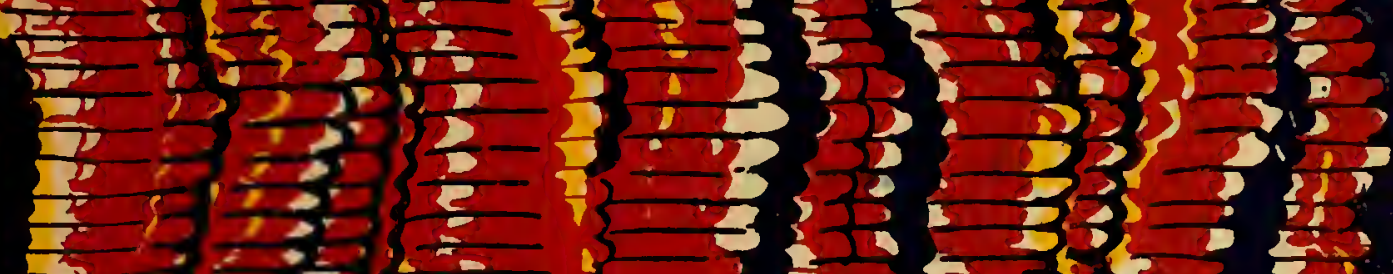

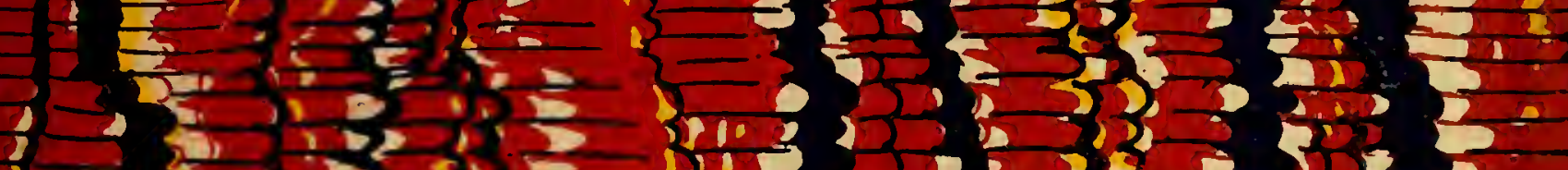

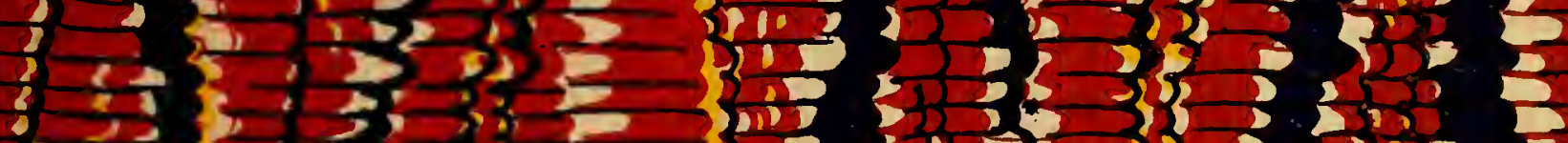

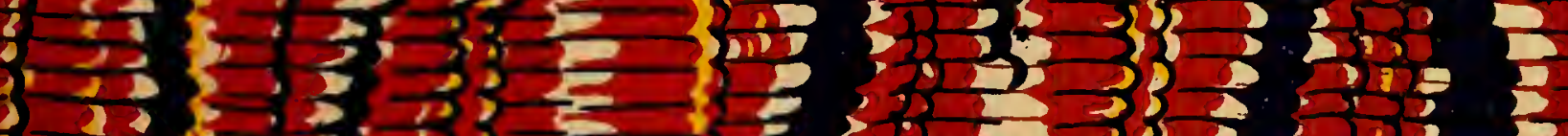

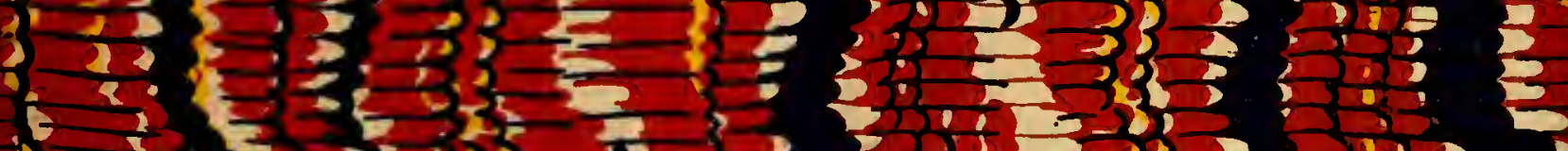

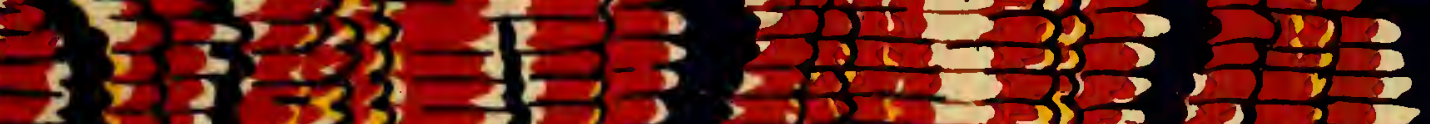

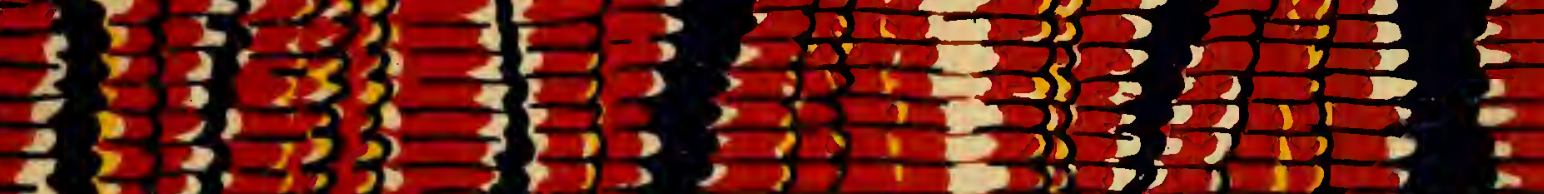

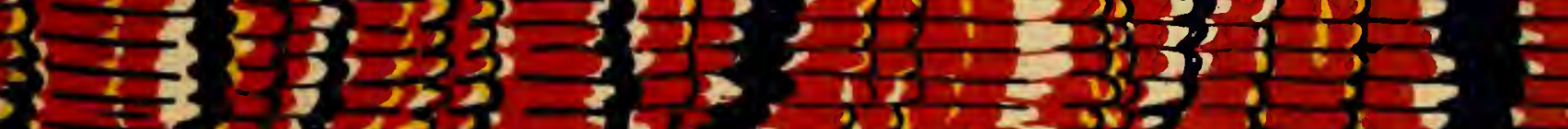

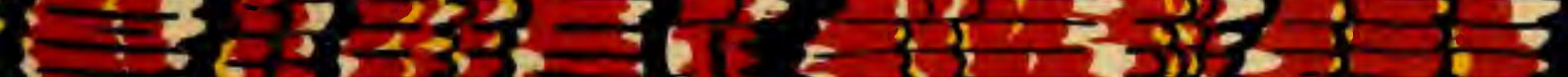

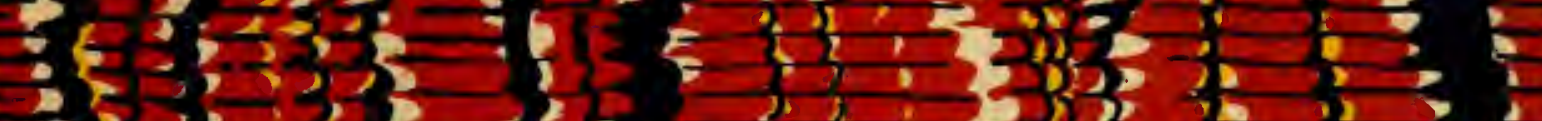

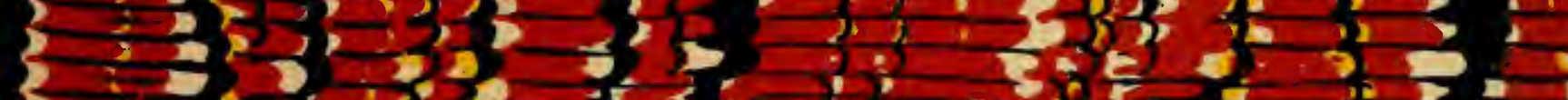

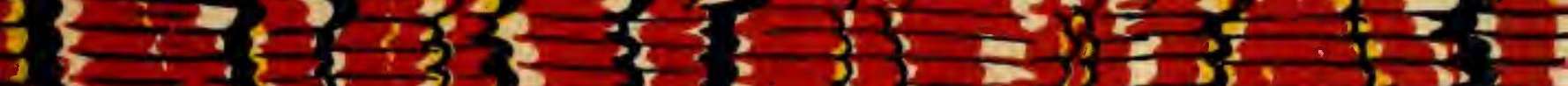

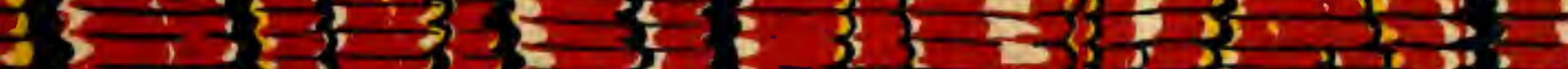
F

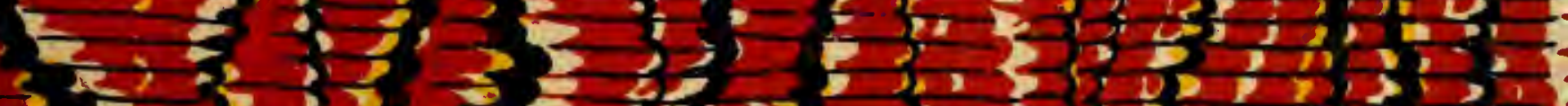

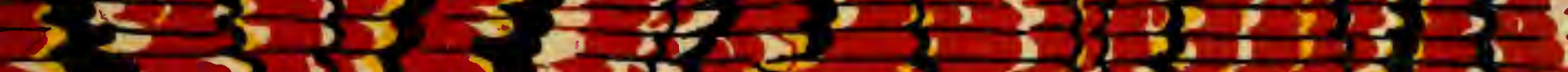

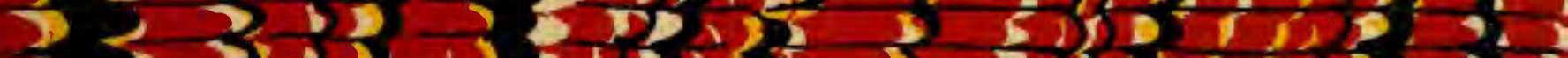

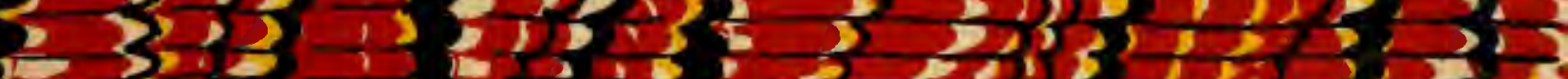

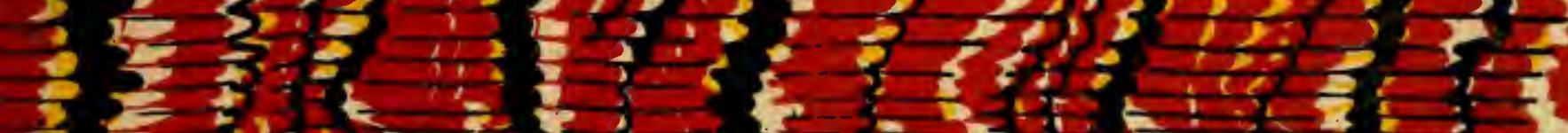

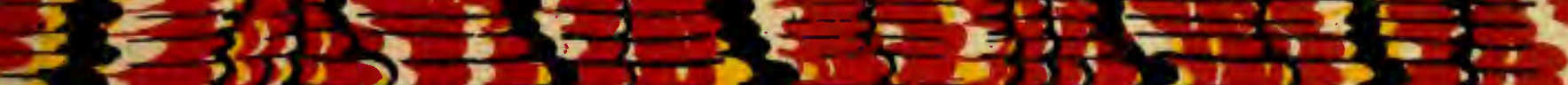

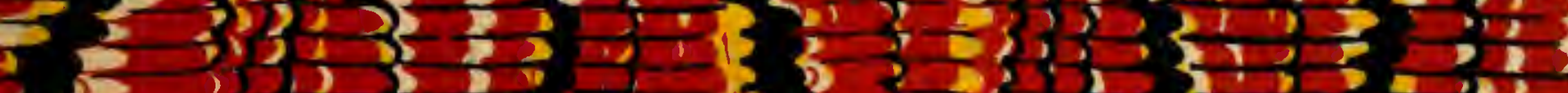

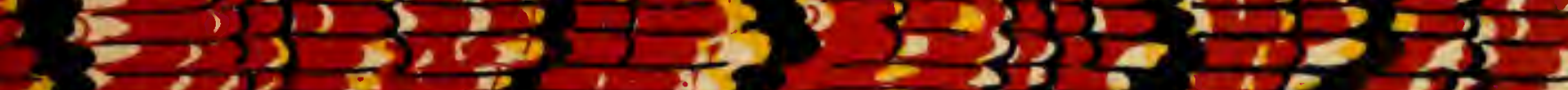

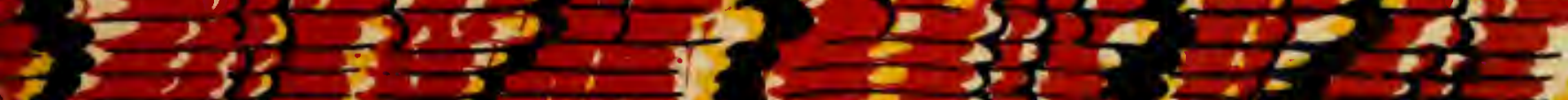

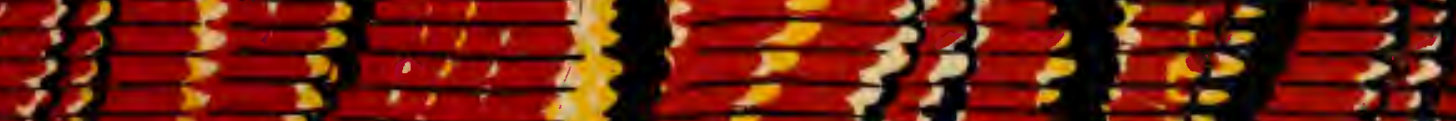

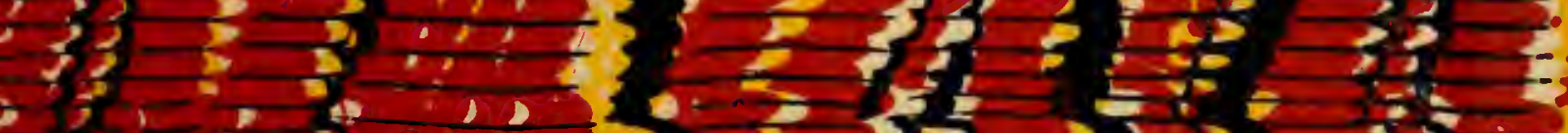

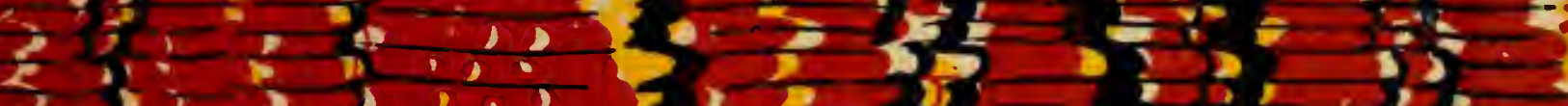

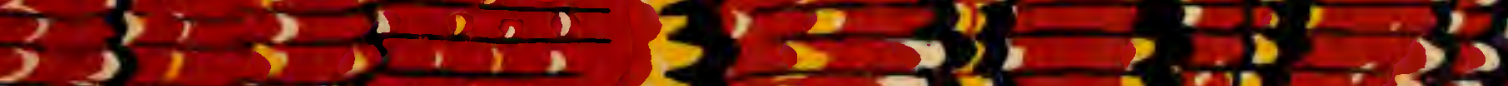

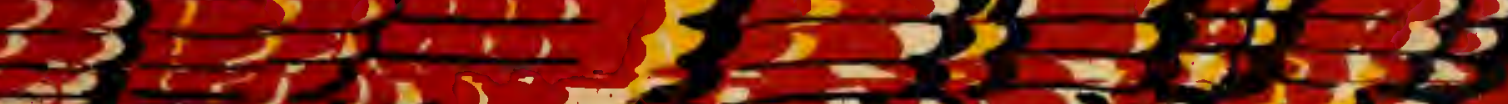

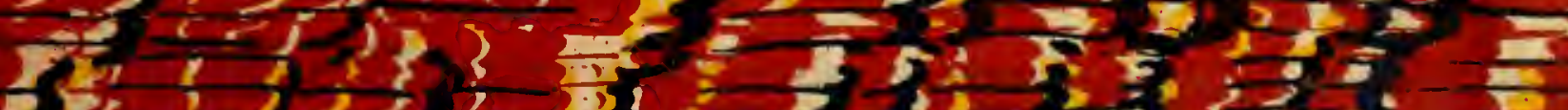

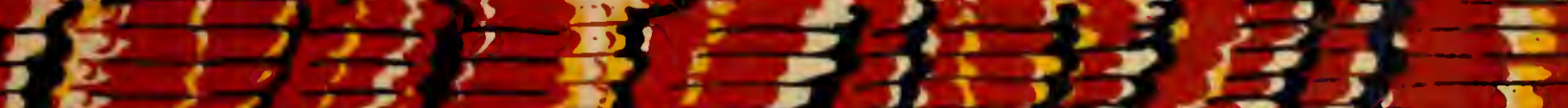

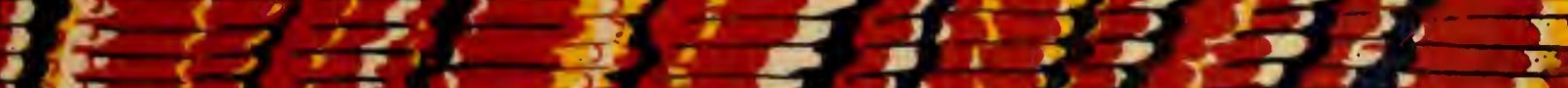


